\title{
PhD THESIS
}

\section{"IMPACT OF MACRO AND MICRO GOVERNANCE STRUCTURES ON EARNINGS MANAGEMENT"}

by

Muhammad Nurul Houqe

\author{
A thesis \\ submitted to the Victoria University of Wellington \\ in fulfilment of the \\ requirements for the degree of \\ Doctor of Philosophy \\ in Accounting
}

Victoria University of Wellington

2010 


\section{$\underline{\text { Research Supervisors: }}$}

Professor Tony van Zij1

Victoria University of Wellington, New Zealand

Professor Keitha Dunstan

Bond University, Gold Coast, Australia

Associate Professor Waresul Karim

Saint Mary's College of California, USA 
This thesis is dedicated to my son Tahmid 


\section{Declaration on Sources}

I hereby confirm that the work presented in this thesis is my own and original that has been carried out through the School of Accounting and Commercial Law, Victoria University of Wellington, during my candidature as a PhD student. I declare that the material of this thesis has not been submitted either in whole or in part for the award of any other degree or diploma at this or any other university. To the best of my knowledge and belief, it contains no material previously published or written by other persons or institutions except where due reference has been made.

(Muhammad Nurul Houqe) 


\section{Acknowledgement}

It is my great happiness to present my humble submission to the omnipotent and omnipresent Almighty for giving me the opportunity and ability to accomplish this thesis. Next, I put forward my profound gratitude to all individuals who helped me with the work on this thesis over the period of my $\mathrm{PhD}$ research. First of all my utmost gratefulness to my advisers Professor Tony van Zijl, Professor Keitha Dunstan and Associate professor Waresul Karim for supervising this research project and providing me countless support and guidance throughout the dissertation process. In this context, I acknowledge that without their supervision and advice, it would have been utterly impossible for me to undertake my thesis in this important and extensive area of empirical research. I am forever grateful for their invaluable suggestions and insights.

I am extremely grateful to Associate professor Waresul Karim and his family especially Ruma Bahbi, Farina, Mukta Apa, Mostafoa Haider Chowdhury for their longterm support and unfailing effort in making the project viable and giving endless encouragement and incredible help from day one to the last day of this project. I will never

forget the very personal care provided by Associate professor Karim both before and during this study in enlightening me in many ways and generating ideas on the topic of the thesis.

On a personal note, my wife Shimi deserves special acknowledgement for making remarkable sacrifices throughout the period of this research. It was her encouragement that got me on this journey. I recognize her underpinning distress throughout this endeavour which has in effect taken all my time, spirit and energy over the last three years. I am also indebted to my family members and other family friends, in particular my mother for her life-long dedication to my study and success in life. Last, but not least, my loving thanks to my son Tahmid who has been a source of encouragement and who has relieved the stress in my life.

Finally, special thanks to the School of Accounting and Commercial Law, Victoria University of Wellington, for the research facilities provided during the whole period of this study. 


\begin{abstract}
This study examines the macro and micro level determinants of the quality of reported earnings. The prior literature suggests that both micro and macro variables impact on discretionary accruals choice in managing earnings. However, most of the studies on earnings management have been single country studies that have focussed only on micro variables as all firms within the samples examined have been subject to the same interplay of macro economic, legal, cultural and institutional frameworks. This study addresses this gap in the literature by using a sample of 156,906 firm year observations from 63 countries over the period 1998-2007 to examine the role of thirteen micro and macro variables in determining earnings quality.

The macro variables studied include legal enforcement, political system, and control of corruption, culture and adoption of IFRS. Earnings management is estimated using the modified Jones model (Dechow et al. 1995) in a cross section (DeFond and Jiambalvo 1994; Francis et al. 1998).

The results of the study indicate that macro and micro level variables have a strong impact on earnings management behaviour and thus earnings quality. The limits imposed by a country's legal, cultural and institutional setting on managerial discretionary accruals choices, strongly impact the quality of reported earnings. Future research on earnings management should therefore control both micro and macro level variables.
\end{abstract}




\section{Table of Contents}

$\begin{array}{lll}\text { Contents } & \text { Page }\end{array}$

Declaration on Sources $\quad$ iv

Acknowledgement $\quad$ v

Abstract vi vi

Table of Contents $\quad$ vii

List of diagrams and Tables $\quad x$

Chapter One: Introduction 1

$1.1 \quad:$ Introduction 2

$1.2 \quad:$ Background of the study 3

$1.3 \quad$ : Significance of earnings management 6

$1.4 \quad$ : Earnings management and macro governance 9

$1.5 \quad$ : Earnings management and micro governance 13

$\begin{array}{lll}1.6 & : \text { Motivation of the study } & 15\end{array}$

$\begin{array}{lll}1.7 & \text { : Structure of the thesis } & 18\end{array}$

$\begin{array}{ll}\text { Chapter Two: Literature Review } & 20\end{array}$

$2.1 \quad$ : Introduction 22

$2.2 \quad$ : Earnings management incentives 22

2.2.1 : Socio-political incentives 23

2.2.1.1 : Degree of enforcement 24

2.2.1.2 : Institutional setting 26

2.2.1.3 : Political system 28

2.2.1.4 : Perceived corruption 30

2.2.1.5 : National culture 32

2.2.2 : Capital market incentives $\quad 35$

2.2.2.1 : Avoidance of reporting loss or earnings decrease 35

2.2.2.2 : Capital market transaction incentives 39

2.2.2.3 : 'Beat or meet' forecasts 41

2.2.3 : Contractual incentives 43

2.2.3.1 : Debt contracts 43

2.2.3.2 : Performance based compensation contracts 45

2.2.4 : Regulatory incentives 47

2.2.4.1 : Industry-specific regulation $\quad 47$

2.2.4.2 : Anti-Trust and other regulation $\quad 48$

$\begin{array}{lll}2.2 .5 & \text { : Industry sectoral differences } & 50\end{array}$ 
2.2.6 : Adoption of IFRS

$2.3 \quad$ : Constraints on earnings management 52

$2.4 \quad$ : Summary 57

Chapter Three: Research Question Development 58

$3.1 \quad:$ Introduction 59

$3.2 \quad:$ Macro governance and earnings management $\quad 60$

3.2.1 : Enforcement and earnings management 62

3.2.2 : Institutional settings and earnings management 65

3.2.3 : Political system and earnings management 66

3.2.4 : Corruption and earnings management 69

$\begin{array}{lll}3.2 .5 & \text { : Culture and earnings management } & 70\end{array}$

3.2.6 : Adoption of IFRS and earnings management 71

$3.3 \quad:$ Micro governance and earnings management $\quad 73$

3.3.1 : Initial public offerings and earnings management 73

3.3.2 : Debt contracts and earnings management 74

3.3.3 : Performance based compensations and earnings management 76

$\begin{array}{lll}3.3 .4 & \text { : Audit quality and earnings management } & 77\end{array}$

$\begin{array}{lll}3.3 .5 & \text { : Board size and earnings management } & 79\end{array}$

3.3.6 : Board effectiveness and earnings management $\quad 80$

3.3.7 : Ownership concentration and earnings management 81

$3.4 \quad$ : Summary 83

Chapter Four: Research Design $\quad 84$

$4.1 \quad:$ Introduction 86

4.2 : Overview of research design 86

4.2.1 : Macro governance and earnings management 88

4.2.2 : Micro governance and earnings management 90

4.2.3 : Joint effect of micro and macro governance and earnings management 90

$4.3 \quad$ : Control variables 91

$4.4 \quad$ : Sample selection and data collection procedure 95

4.4.1 : Study period $\quad 95$

4.4.2 : Sample selection 97

4.5 : Operationalisation of the constructs 98

4.5.1 : Macro governance 98

$\begin{array}{lll}4.5 .2 & \text { : Micro governance } & 101\end{array}$

$\begin{array}{lll}4.5 .3 & \text { : Earnings management } & 102\end{array}$

4.5.3.1 : Aggregate accruals model 105

4.5.3.1(i) : Jones (1991) model 107

4.5.3.1(ii) : Modified Jones (Dechow et al. 1995) model 107

4.5.3.2 : Cross-sectional models 109

4.5.3.2(i) : Cross-sectional Jones model 109

4.5.3.2(ii) : Cross-sectional modified Jones model 110 


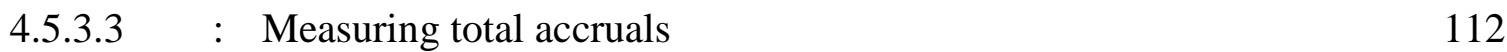

4.6 : Analytical procedures 113

4.6.1 : Step one: Data collection and descriptive statistics 113

4.6.2 : Step two: Computing discretionary accruals 114

4.6.3 : Step three: Regression analysis 114

4.6.4 : Step four: Robustness tests 114

$4.7 \quad:$ Research questions 115

$\begin{array}{llll}4.8 & \text { : Summary } & 117\end{array}$

Chapter Five: Analysis of the Results $\quad 122$

$\begin{array}{llll}5.1 & : \text { Introduction } & 123\end{array}$

$\begin{array}{lll}5.2 & \text { : Univariate analysis } & 123\end{array}$

$\begin{array}{lll}5.3 & \text { : Discretionary accruals } & 125\end{array}$

$5.4 \quad:$ Test of the research questions $\quad 126$

5.5 : Robustness tests 175

5.5.1 : Using cross-sectional Jones (1991) model 175

$\begin{array}{lll}5.5 .2 & \text { : Deleting smaller countries } & 176\end{array}$

$\begin{array}{lll}5.6 & 177\end{array}$

Chapter Six: Conclusion $\quad 178$

$\begin{array}{llll}6.1 & : \text { Introduction } & 179\end{array}$

6.2 : Summary of the research findings 179

$6.3 \quad$ : Implications of the study 181

$6.4 \quad$ : Limitations of the study 182 
List of References

\section{Appendices}

Appendix A : Statistical output 212

Appendix B : Definition of financial number games 220

Appendix C : Brief Sketch of empirical studies on earnings management 221

Appendix D : Robustness test 227

\section{List of Diagrams and Tables}

\section{Diagrams}

$1.1 \quad$ : The distinction between fraud and earnings management 5

$1.2 \quad$ : Motivation for the study 18

$\begin{array}{llll}4.1 & \text { : Conceptual model } & 88\end{array}$

\section{Tables}

4.1 : Panel A: Sample selection 97

$4.2 \quad$ : Operationalisation of explaining constructs (macro) 99

$4.3 \quad$ : Operationalisation of explaining constructs(micro) 101

$4.4 \quad:$ Research designs from the earnings management literature 103

$4.5 \quad$ : Discretionary accruals models 106

4.6 : Summary of research questions 116

$4.7 \quad$ : List of variables 118

5.1 Panel A : Sample distribution by country and year 212

5.1 Panel B : Measures of macro governance variables for the 63 countries in the study 214

5.1 Panel C : Measures of micro governance variables for the 63 countries in the study 216

5.1 Panel D : Pearson Correlation on macro and micro governance variables with DACCR 218

$\begin{array}{lll}5.2 & \text { : Descriptive statistics } & 219\end{array}$

$5.3 \quad$ : Estimation of the parameters of total accruals model for the full Sample 126

5.4(i) : Regression analysis of discretionary accruals with judicial $\begin{array}{ll}\text { independence } & 129\end{array}$

5.4(ii) : Regression analysis of discretionary accruals with enforcement of securities laws 130

5.4(iii) $\quad:$ Regression analysis of discretionary accruals with protection of 
minority shareholders interest

5.4(iv) : Regression analysis of discretionary accruals with enforcement of accounting and auditing standards

132

5.4(v) : Regression analysis of discretionary accruals with rule of laws 133

5.4(vi) : Regression analysis of discretionary accruals with press freedom $\quad 134$

$5.5 \quad$ : Regression analysis of discretionary accruals with institutional setting

$5.6 \quad$ Regression analysis of discretionary accruals with political $\begin{array}{ll}\text { system } & 140\end{array}$

$5.7 \quad:$ Regression analysis of discretionary accruals with corruption $\quad 143$

$5.8 \quad$ : Regression analysis of discretionary accruals with culture $\quad 145$

5.9(i) : Regression analysis of discretionary accruals with adoption of IFRS

5.9(ii) : Regression analysis of discretionary accruals with adoption of IFRS and macro governance

$5.10 \quad$ : Regression analysis of discretionary accruals with initial public offerings 151

$5.11 \quad$ : Regression analysis of discretionary accruals with debt contracts 153

5.12 : Regression analysis of discretionary accruals with performance based compensations 155

5.13(i) : Regression analysis of discretionary accruals with audit quality 157

5.13(ii) : Regression analysis of discretionary accruals with audit quality $\begin{array}{ll}\text { and macro governance } & 159\end{array}$

5.14(i) : Regression analysis of discretionary accruals with board size $\quad 161$

5.14(ii) : Regression analysis of discretionary accruals with board size and macro governance 163

5.15(i) : Regression analysis of discretionary accruals with board effectiveness 165

5.15(ii) : Regression analysis of discretionary accruals with board $\begin{array}{ll}\text { effectiveness and macro governance } & 167\end{array}$

5.16(i) : Regression analysis of discretionary accruals with ownership $\begin{array}{ll}\text { concentration } & 169\end{array}$

5.16(ii) : Regression analysis of discretionary accruals with ownership concentration

5.16(iii) : Regression analysis of discretionary accruals with ownership $\begin{array}{ll}\text { concentration and macro governance } & 174\end{array}$

5.17 : Using cross-sectional Jones (1991) model: Regression analysis of discretionary accruals with macro governance 227

5.18 : Using cross-sectional Jones (1991) model: Regression analysis of discretionary accruals with micro governance

5.19 : Deleting small countries: Regression analysis of discretionary $\begin{array}{ll}\text { accruals with macro governance } & 229\end{array}$

5.20 : Deleting small countries: regression analysis of discretionary accruals with micro governance 


\section{Chapter One}

\section{Introduction}

1.1 Introduction

1.2 Background of the study

1.3 Significance of earnings management

1.4 Earnings management and macro governance

1.5 Earnings management and micro governance

1.6 Motivation of the study

1.7 Structure of the thesis 


\subsection{Introduction}

This study examines the macro and micro-level determinants of earnings management. Most studies on earnings management attempt to identify firm attributes affecting earnings management by analyzing cross-sectional variation in earnings quality ${ }^{1}$ in a single country setting, that is, where all firms operate under the same institutional, economic, and regulatory arrangement. While this approach has merit, it ignores the context in which accounting information is produced in that it fails to capture the role of macro variables such as rule of law, economic freedom, press freedom, degree of corruption, level of auditor professionalism, effectiveness of securities market oversight bodies, and rigor of law enforcement (both securities law and other laws). Therefore, the present study deals with a multi country sample of 156,906 firm year observations from 63 countries and thus permits investigation of the impact on earnings quality of both firm level and country level variables ${ }^{2}$. As such, the present study extends and complements the accounting literature that examines the association between governance quality and firms' earnings management practices.

The remainder of this chapter proceeds as follows. Section 1.2 outlines the background of the study. Section 1.3 discusses the significance of earnings management. Sections 1.4 and 1.5 discuss the relevance of macro and micro governance on earnings management. Section 1.6 discusses the motivation for the study and, finally, Section 1.7 sets out the structure of the thesis.

1 In the accounting literature, the terms, earnings quality, and accounting quality are interchangeably used.

2 In the accounting literature, the terms firm level and micro governance and country level and macro governance are interchangeably used. 


\subsection{Background of the study}

Financial statements prepared by business organizations are expected to provide information relevant to users making investment, enduring and other decisions. To be useful, these statements should be prepared on the basis of accounting principles generally accepted in the country or jurisdiction (GAAP) where the firm is based or where its securities are listed. GAAP in any jurisdiction provides a degree of latitude in allowing firms to selectively use principles and procedures in accounting for and reporting firm performance to stakeholders. Managers' have information advantage over the users of accounting information and they can use this advantage in selecting the procedures for estimation and even the timing and language of disclosure to suit their own short-term goals, often to the detriment of the long-term value of the firm. This potentially decreases the value of accounting as a relevant and credible form of communication. Opportunistic use of this discretion is described as "earnings management", in which managers choose reporting methods and estimates to bias accounting numbers by masking true firm performance. At least two aspects of the debate on alternative accounting policy choice are relevant at this point. One, whether choice in accounting should exist at all, that is whether managers should be allowed to choose a method to account for an underlying economic event from a pool of methods - all of which are regarded as being legitimate? Two, whether the existence of choice per se has a link to managerial opportunism in the form of earnings management (Houlthausen and Larker 1996). Unfortunately, neither aspect of the accounting policy choice debate has been resolved although in recent years regulators appear to prefer fewer choices over more. In regards to reporting flexibility, Mulford and Comiskey (2002) believe flexibility is essential to allow accounting numbers to 
reflect the often varied underlying economic substance of the transactions undertaken by firms even within the same industry. The US SEC is clearly in favour of fewer options while many IASB standards still allow choices. In spite of the recent wave of global convergence of accounting standards, it appears likely that legitimate accounting choices will remain a fact of life.

Besides the existence of choice in accounting, accrual accounting of itself creates opportunities for earnings management. The principal goal of accrual accounting is to help stakeholders assess an entity's economic performance through the use of a number of accounting principles such as revenue recognition and matching (FASB 1985). However, accrual accounting is often subjective, leaving room for managerial discretion and hence a potential for misuse. Thus, on the one hand, accrual accounting is expected to enhance the value of accounting information by improving relevance and allowing managers to share their private knowledge of the firm with outsiders. On the other hand, the subjectivity involved in accrual accounting could allow managers to be opportunistic and mislead investors in order to acquire private gains. Therefore, understanding earnings management requires understanding managerial intent. It is important to note that neither the existence of accounting alternatives nor application of the accrual basis of accounting per se result in earnings management. Rather it is the managerial intent behind using a particular discretion that may result in earnings management (Mulford and Comiskey 2002). 


\section{Diagram 1-1: The distinction between fraud and earnings management}

\section{The Distinction between Fraud and Earnings Management}

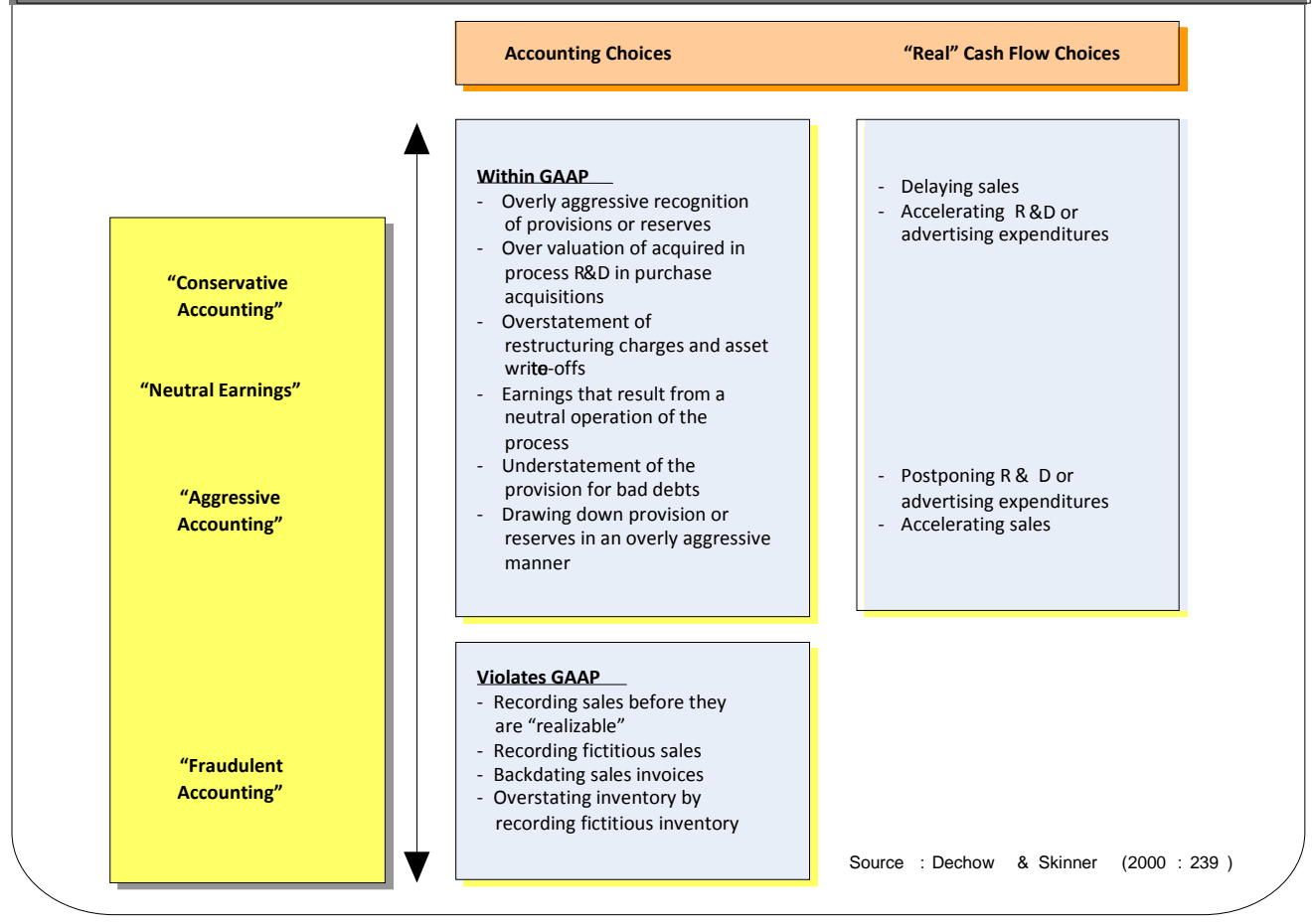

Dechow and Skinner (2000) makes explicit reference to the lack of a clear definition of earnings management in both the academic and professional literature. They offer their own view on how different types of managerial choices can be characterized, as reproduced in Diagram 1-1. Academic research on earnings management has focused much on identifying various incentives for earnings management and how to appropriately measure the 'managed' portion of reported earnings. Recent research has further extended the boundary of earnings management to identify factors that constrain earnings management behavior of corporate managers.

The bulk of the research on earnings management has been conducted on countries with more effective governance mechanisms in place. Few studies have 
focussed on emerging markets where it is relatively easier for management to expropriate minority shareholders' interest because of lack of effective governance structure such as dispersed ownership, independent boards, independent auditors, existence of active takeover markets, and higher quality disclosure. Moreover, the extant literature focuses mainly on firm-level determinants of earnings management and thus largely ignores cross-country variation due to macro governance factors. Only a handful of studies have been undertaken to examine the possible effect of political, cultural, and institutional governance mechanisms on earnings quality at a county level. This study aims to fill this gap in the literature by investigating the impact of macro as well as micro governance factors on earnings management from a global perspective.

\subsection{Significance of earnings management}

Accounting numbers are extensively used in writing contracts between and among stakeholders, most of whom are external to the firm. They do not have physical or direct access to the day-to-day operations of the business and rely heavily on the accounting numbers produced by the accounting information systems, certified by directors and verified by auditors. Since the seminal work of Beaver (1968) and Ball and Brown (1968), much evidence has accumulated showing that accounting numbers have information content, albeit of different magnitudes. The very functioning of financial markets involving trillions of dollars of transactions every day critically depends on the credibility of accounting numbers underlying those transactions. Therefore, the need for high quality of accounting numbers in general and accounting earnings in particular cannot be overemphasized. The high profile 
accounting scandals of the last decade emphasise the high reliance of global capitalism on the veracity of the financial statements of publicly held corporations. There is a relatively long history of debate between regulators, auditors, and academic researchers on the potential threat of earnings management that reduces the quality of financial reporting (La Porta et al. 1999).

"Earnings management" has been a key concern of the IASB, FASB, AICPA, PCAOB and other regulatory bodies and is the central reason behind many aspects of accounting regulation (Sarbanes Oxley Act 2002). It impacts on the confidence of investors and other actors in all financial markets. In recent years there has been a heightened emphasis on corporate governance issues. Most countries have either adopted SOX-type rules for the corporate sectors or legislated similar provisions to improve accountability and transparency. However, most regulators have not addressed or are powerless to address the political governance prevailing in their countries. Accountability and transparency at the macro governance level has largely escaped scrutiny. This study reflects the view that improvement in accounting quality cannot be achieved by effecting reforms in corporate boardrooms alone. It is therefore important to work on the political (macro) governance framework vis-a-vis corporate governance if improvement in accounting quality is to be made. For this reason, this study contributes to the literature by incorporating a comprehensive set of governance (both micro and macro) variables on a sample drawn from across the globe. The concept of earnings quality relates to preparers understanding the economic substance of a transaction, and then reflecting it without distortion in the books of the firm. However, this is not always a simple task, as accounting rules are not always black and white, and with transactions becoming ever more complex. The 
$\mathrm{CFO}$, an expert in the management of process, technology and resources has a key role in a company's decision-making process to guide and shape decisions that make better sense of transactions within the context of GAAP and regulatory reporting requirements.

While managing the underlying operations of a business to achieve a desired outcome or to hit an earnings target is entirely appropriate; managing earnings estimates to hit earnings targets however, is not an acceptable means. The IASB, FASB, AICPA and other regulatory bodies continue to provide guidance and direction to ensure that the financial reporting community report high quality earnings and provide the necessary disclosures to enable the investing public to make better informed decisions. One way of doing this is through the creation of a robust performance measurement system incorporating both financial and non-financial measures that not only measure the current performance and position but are also predictive of future conditions in the business. Knowing and understanding key metrics in a company can lead to better decision-making and reporting, and thus higher quality of earnings. Having an effective early-warning system in place could obviate any need for managing earnings.

Healy and Wahlen (1999) define earnings management as the alteration of firms' reported economic performance by insiders to either "mislead some stakeholders" or to "influence contractual outcomes." The disclosure of "true and fair" financial earnings is crucial to corporate governance because it provides outsiders with a basis to monitor their claims and exercise their rights (OECD Principles of Corporate Governance 1999). The incentives to misrepresent firm performance through earnings management arise from the conflict of interest between 
the firms' insiders and outsiders. As Jensen and Meckling (1976) point out, insiders have an incentive to use the firms' resources in a way that benefits them, possibly at the expense of outsiders. In the presence of extensive earnings management, financial reports inaccurately reflect firm performance and consequently the ability of outsiders to monitor the performance of the firm is weakened. The ability of insiders to acquire private control benefits is limited by an explicit institutional framework, through corporate governance mechanisms and the legal system in protecting the interests of outside minority shareholders (Shleifer and Vishny 1997; La Porta et al. 2000).

The majority of studies on earnings management are performed at firm level, within one country. Typically, the research investigates the relationship between corporate governance settings and earnings management (Peasnell et al. 2000; Beasley 1996; Klein 2002; DeFond and Jiambalvo 1991). Recently, several studies have compared macro governance settings and management practices across countries (Leuz et al. 2003; Francis and Wang 2008). Prior research suggests that greater legal protection of outside investors increases insiders' costs of diverting firm profits or assets (Shleifer and Wolfenzon 2000; Claessens et al. 2000a; Nenova 2000). Consistently, Leuz et al. (2003) find a significant negative relationship between outside minority protection and earnings management.

\subsection{Earnings management and macro governance}

Reports of earnings management frequently appear in the financial press. The Financial Times (June 19, 2004) reports that UK companies were less likely to use aggressive accounting practices to manage their earnings than a few years ago because of changes in the corporate environment. This report preliminary finding by 
John Collier, chief executive of the Institute of Chartered Accountants in England and Wales, the threat of aggressive earnings management could increase when financial markets start to heat up again. Many corporate respondents interviewed by Mr. Collier complained of the considerable pressure that companies remained under to meet market expectations, for fear of being labelled "unreliable" by analysts. Bonuses are also cited as a cause of aggressive earnings management. In September 1998, UK accounting standard setters attempted to limit the use of provisions as a profit manipulation device. The Accountant (November 1, 1998) reports this event with an article titled "Standard-setter bans 'big-bath' accounting." By depressing profits in good years and bumping up the bottom line when times are bad, over-generous provisions are a classic creative accounting device for smoothing earnings. In good years UK companies made excessive provisions for future reorganizations, and later fed those provisions back into income.

Prior academic literature tends to argue that high-quality investor protection, strong legal enforcement, and a common law legal system are fundamental determinants of high-quality financial statement numbers (Luez et al. 2003). This study contributes to a growing literature that examines how a country's corporate governance model, legal system and the existence and enforcement of laws, and other institutional factors affect the quality of reported financial information.

Consistent with Kothari (2000), this study argues that the quality of financial information is a function of both the quality of accounting standards and the regulatory enforcement of the standards that is macro governance. In line with Ball et al. (2003), the present study argues that a country with high-quality accounting standards would or does not necessarily have high-quality reported financial 
information. However, it is extremely unlikely that a country with a low-quality accounting and disclosure system would have high-quality reported financial information, even though it has strong investor protection and legal enforcement. Hung (2001) examines the relation between accrual accounting and the value relevance of accounting measures in countries with different levels of shareholder protection. She finds that stronger shareholder protection improves the effectiveness of the accrual system. She argues that accrual accounting provides better matching of revenues and expenses than cash accounting and therefore makes accounting information more value relevant. However, accrual accounting also presents more opportunities for managers to manage earnings and hence may cause accounting information to be less value relevant. She predicts that weak shareholder protection will attenuate this negative impact.

Hope (2003) investigates the relation between the accuracy of analysts' earnings forecasts and the level of annual report disclosure, and the relation between forecast accuracy and the degree of enforcement of accounting standards. He finds that firm-level disclosures in annual reports are positively associated with analyst forecast accuracy, suggesting that such disclosures provide useful information to analysts. Using a comprehensive measure of enforcement, he finds that strong enforcement is associated with higher forecast accuracy. He concludes that enforcement encourages managers to follow prescribed accounting rules, which in turn reduces analysts' uncertainty about future earnings.

A potential question is why managers would choose to "openly" manage earnings if it could have negative effects on investors' willingness to hold shares. In some cases, it may result from managers creating capacity for personal gain. 
However, it is important to note that earnings management, even if it reduces investors' willingness to trade, may be optimal for the firm. For example, in many countries stakeholders other than shareholders are important and this may create incentives to manage earnings. Labour unions, for instance, may create incentives to manage earnings because high profits attract greater compensation demands while losses create concerns about viability. Similarly, firms may manage earnings to reduce perceived risk and attract lower interest rates on debt, lower taxes or reduce political costs. Dichev and Tang (2005) suggest that earnings management is a function of matching and could enhance transparency while research such as Leuz et al. (2003) argues that opportunistic smoothing reduces transparency. Similarly, this study expects that both factors may be at work in practice, with innate earnings management increasing transparency and discretionary smoothing increasing opacity. While the former effect may dominate in US settings, where governance tends to be relatively strong, this study expects that the latter effect may be particularly pronounced in certain country settings where incentives to manage earnings may be relatively strong and oversight relatively weak.

This study seeks to identify the effects, if any, of macro governance, in particular, country level governance on earnings management. It views rule of law, press freedom, judiciary independence, institutional settings, political systems, and corruption as constituents of "macro-level governance." Macro-level governance prescribes desirable modes of wielding political, economic, or other forms of power. This study postulates that the potency of such norms depends upon the effectiveness of prevailing macro level governance in a society. Poor political governance breeds 
corruption and this in turn is likely to impede production of high quality accounting numbers. This leads to the question:

\section{"Does macro governance influence earnings management?"}

\subsection{Earnings management and micro governance}

'Earnings management' is a form of earnings manipulation that is likely to reduce the quality of earnings that interference with the estimation process to misrepresent reality is, by definition, poor quality ${ }^{3}$ This relation is empirically established in the literature (Francis and Wang 2008; Hope et al. 2008; Wang et al. 1994; Ali and Hwang 1995; and Cheng et al. 1997). When mangers manage earnings for opportunistic purposes, accounting earnings become a less dependable measure of a firms' financial performance. Accordingly, it is justifiable to use earnings management as an indicator of the quality of earnings.

Accounting earnings are more dependable and consequently of higher quality when managers' opportunistic behaviour is controlled using monitoring systems (Wild 1996; Dechow et al. 1996). Klein (2002b) and Peasnell et al. (2000a) show that

\footnotetext{
3 Managers have some degree of flexibility and discretion in reporting their financial performance and they may use it either opportunistically to manage earnings (Christie and Zimmerman 1994) or they may use it to communicate private value-relevant information about the firm's future performance (Jones 1991; Healy and Palepu 1993). However, much of the extant literature finds that earnings management is carried out with the intention of either misleading financial statement users or of biasing contractual outcomes that depend on accounting earnings. Recent studies have provided evidence of income-increasing opportunistic earnings management related to initial public offerings (Teoh et al. 1998a; Teoh et al. 1998), seasoned public offerings (Teoh et al. 1998b), stock financed acquisitions (Erickson and Wang 1998), meeting analyst earnings expectations (Payne and Robb 2000; Burgstahler and Eames 2006), meeting management forecasts (Kasznik 1999), and avoiding earnings decreases and losses (Burgstahler and Dichev 1997). Examples of settings leading to income-decreasing earnings management include management buyouts (DeAngelo 1988; Perry and Williams 1994), executive compensation (Healy 1985; Holthausen et al. 1995), and appeals for import relief (Jones 1991). This body of research has found convincing evidence of opportunistic earnings management in settings where strong incentives to manage earnings exist.
} 
monitoring attributable to micro or firm-level governance reduces managements' capacity to manage earnings. ${ }^{4}$ Monitoring attributable to firm-level governance has the capacity to improve the dependability of accounting earnings; and therefore, increases the quality of accounting earnings. Micro governance also helps investors by aligning the interest of managers with the interests of shareholders and enhancing the dependability of financial information and the integrity of the financial reporting process (Watts and Zimmerman 1986). ${ }^{5}$ The results of Gul and Tsui (2001) support the effectiveness of micro governance as a monitoring system. Given that earnings management is negatively related with micro governance and that micro governance is positively related with the integrity of the financial reporting process, it is then justifiable to also use micro governance as an indicator of the quality of accounting earnings.

If micro governance and/or earnings management improve the explanatory power of accounting earnings, then the results should support the proposition that investors use other value relevant information (i.e. micro governance and earnings management) to assess earnings quality. There is little guidance on how micro governance impacts on the quality of accounting earnings. Prior research offers no comprehensive theoretical explanation for the role earnings management tends to

4 Micro governance is a system used to achieve firm objectives and monitor performance (OECD 1999). Good micro-level governance should align the objectives of management with the objectives of shareholders (Cadbury report 1992; OECD 1999) and should facilitate effective monitoring, thereby encouraging managers to use resources more efficiently (OECD 1999).

5 Micro governance's primary objective is not to directly improve corporate performance, but to resolve agency problems by aligning management's interests with the interests of shareholders (Maher and Andersson 2000). A large segment of the firmlevel governance literature focuses on directly linking firm-level governance to corporate performance. Empirical results from the literature are mixed and indecisive (Lawrence and Stapledon 1999). 
play in the micro governance-earnings management relationship. As a result, the second relevant question is:

\section{“Does micro governance influence earnings management?"}

\subsection{Motivation of the study}

The aim of the proposed study is to examine the impact of governance on accounting quality across national boundaries. For the purpose of this study, accounting quality is measured by discretionary accruals (DACCR) ${ }^{6}$. In its attempt to explain managerial discretion on accruals' choice, earnings management research to date has mainly focused on specific characteristics of a firm including its governance. In her seminal work on examining managers' accrual choice behavior, Jones (1991) finds that managers decrease earnings through earnings management during import relief investigation. Dechow et al. (1995) examine alternative accruals-based models for detecting earnings management. They find that a modified version of the model developed by Jones (1991) exhibits the most power in detecting earnings management. Kothari et al. (2002) finds that performance matched discretionary measures enhance the reliability of inferences from earnings management research when the hypothesis being tested does not imply that earnings management will vary with performance or where the control firms are not expected to have engaged in earnings management.

A significant body of earnings management research tends to relate accounting discretion to aspects of firm-level governance, such as the level of

6 For a comprehensive discussion on discretionary accruals, see Healy and Wahlen (1999). 
managerial ownership (Warfield et al. 1995), auditor quality (Becker et al. 1998; Chen et al. 2005), audit committee independence and board independence (Klein 2002; Lin et al. 2006; Ebrahim 2007). However, individual aspects of governance structure are likely to be interrelated and ignoring such relationships can lead to spurious inferences (Bhagat and Jefferris 2002). This study contributes to the literature on the relation between macro and micro governance and accounting discretion by using a comprehensive set of governance variables. It also aims to identify firm-level incentives for and constraints on earnings management.

While the area of earnings management boasts a huge body of literature produced over the period since Jones (1991), it ignores the role of national political governance arrangements such as the existence and practice of democracy, enforcement of law, degree of corruption in bureaucracy and government, in shaping managers' earnings management behavior. The broad premise of the present study is based on the established argument that accounting does not exist in a vacuum, rather it 'is a product of its environment' (Mueller 1968; Nobes 1988 and 1992; Karim 1995). Therefore, it can be argued that earnings management is more likely to take place in countries with higher levels of overall corruption associated with poor governance. In other words, the quality of political governance is linked to the quality of corporate governance which, in turn, is linked to the quality of accounting numbers.

Given accounting differences across countries the traditional approaches taken in the extant earnings management literature might be considered a sensible approach to identify corporate attributes determining the existence and magnitude of earnings management within individual countries. However, with adoption of or 
announcement of a decision to adopt IFRS by the EU, Australia, New Zealand and many developing countries in recent years, national accounting differences are likely to reduce if not disappear altogether. Therefore, the present international accounting scene provides an opportunity to see if differences in international governance arrangements are linked to observed levels of earnings management i.e. differences in earning quality. This study uses a multinational sample covering firms from all over the world as available from the OSIRIS database. This will, on the one hand, allow investigation of firm-level determinants of earnings quality such as size, leverage, profitability, timing of the issue of financial statements, likelihood of breaching debt covenants, in addition to corporate governance attributes such as board size, board effectiveness, ownership concentration extent of incentive-based compensation and auditor quality. On the other hand, and perhaps more importantly, it will allow investigation of influence of macro governance variables such as country-level perceived corruption, freedom of judiciary, press freedom, securities market oversight capacity, strength of the accounting profession, national culture and level of bureaucratic corruption within sample countries. On the basis of above discussion, diagram 1-2 shows how macro and micro level governance affects earnings management. 


\section{Diagram 1-2: Motivation of the study}

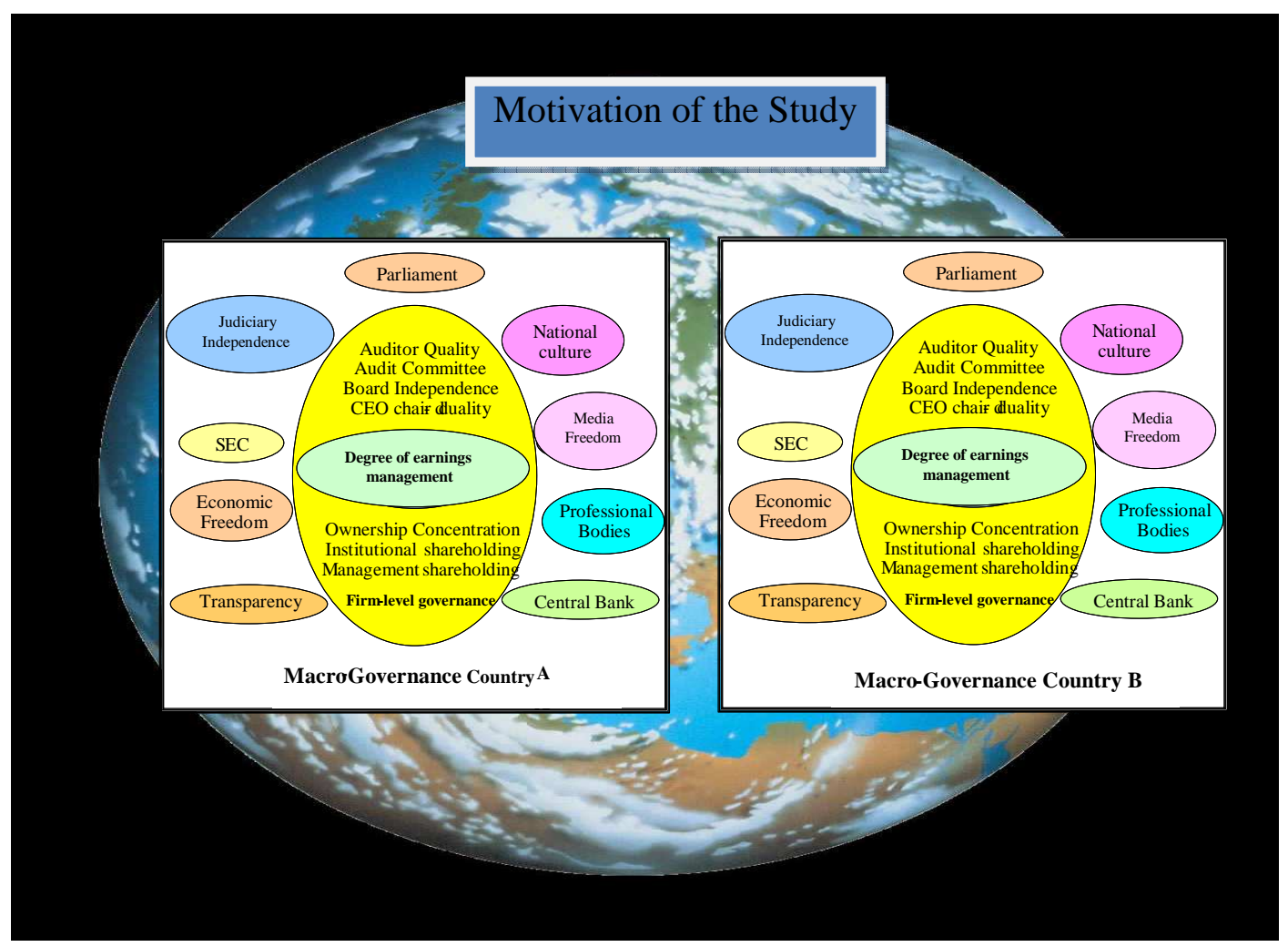

\subsection{Structure of the thesis}

Chapter one has provided an introduction to the thesis.

Chapter Two reviews the empirical studies on earnings management incentives with macro and micro governance and earnings management relationships.

Chapter Three develops the research questions tested in this study. The research questions pertain to the relationship between both macro and micro governance on earnings management and reflect the review of the literature set out in Chapter Two.

Chapter Four describes the research method and techniques used to test the research questions developed in Chapter Three. The chapter begins with an overview of the models and restates the propositions as research questions to be empirically 
tested. A description of the sample, study period, and data collection is followed by the operationalisation of the theoretical constructs. Finally, the chapter presents an explanation of the analytical procedure.

Chapter Five starts with descriptive statistics and correlation analysis. This is followed by the presentation of the results of the tests and the inferences drawn from the tests. The chapter concludes with a discussion of the robustness checks.

Chapter Six summarises the finding of the study including limitations on the results. The chapter also investigates the implications of the study for practitioners, and regulators. 


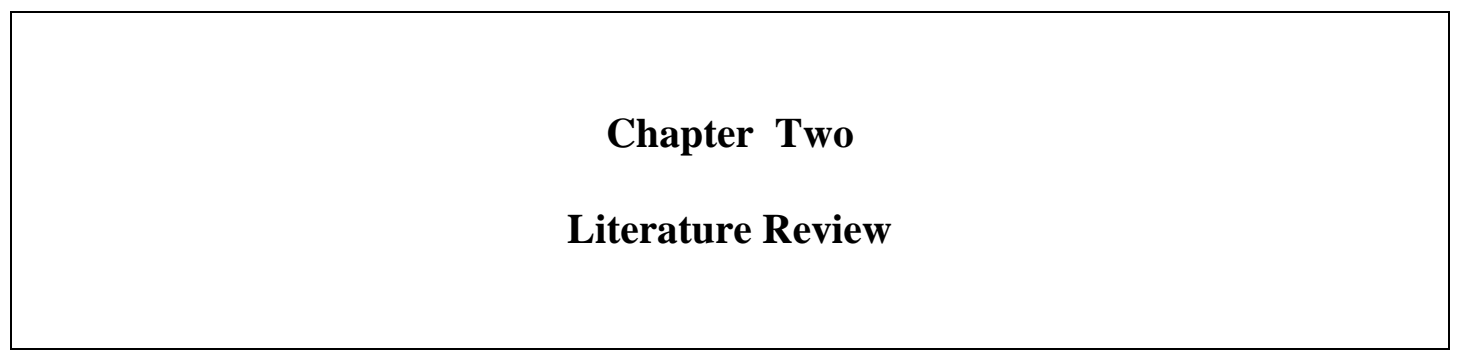

2.1 Introduction

2.2 Earnings management incentives

2.2.1 Socio-political incentives

2.2.1.1 Degree of enforcement

2.2.1.2 Institutional setting

2.2.1.3 Political system

2.2.1.4 Perceived corruption

2.2.1.5 National culture

2.2.2 Capital market incentives

2.2.2.1 Avoidance of reporting loss or earnings decrease

2.2.2.2 Capital market transaction incentives

2.2.2.3 'Beat or meet' forecasts

2.2.3 Contractual Incentives

2.2.3.1 Debt contracts

2.2.3.2 Performance based compensation contracts

2.2.4 Regulatory incentives

2.2.4.1 Industry-specific regulation 
2.2.4.2 Anti-Trust and other regulations

2.2.5 Industry sectoral differences

2.2.6 Adoption of IFRS

2.3 Constraints on earnings management

2.4 Summary 


\subsection{Introduction}

Earnings management research has addressed a variety of micro and macro governance mechanisms to mitigate the managerial rent seeking behaviour. This chapter reviews the relevant literature to date, with particular focus on possible motivations for and constraints on earnings management.

The chapter proceeds with a discussion of incentives of earnings management in the next section. Section 2.3 discusses literature on constraints to earnings management while Section 2.4 provides a summary of the chapter.

\subsection{Earnings management incentives}

Healy and Wahlen (1999) identify two critical research design issues arising from earnings management literature. They argue that researchers have to first identify managers' reporting incentives and secondly measure discretion in accounting method choices. With regard to the first issue, the literature has identified the following major factors : (i) Socio-political incentives; (ii) Capital market incentives;

(iii) Contractual incentives; and (iv) Regulatory incentives; (v) Industry sectoral differences; and (vi) Adoption of IFRS.

Management exercise of discretion in accounting policy choice can be estimated from unexpected accruals, with some (inevitable) degree of error. To estimate unexpected accruals, many studies begin with total accruals, measured as the difference between reported net income and cash flows from operations (Jones 1991; Dechow et al. 1995; and Subramanyam 1996). Total accruals are then regressed on variables that are proxies for non-discretionary (normal) accruals, such as revenues (or cash collections from customers), to allow for typical working capital needs (such 
as receivables, inventory, and trade credit), and gross fixed assets to allow for normal depreciation. Discretionary (unexpected) accruals are thus the unexplained (i.e. the residual) component of total accruals. A number of recent studies have developed estimates of the unexpected components of specific accruals, such as loan loss provisions for banks, claim loss reserves for property casualty insurers (Beaver and McNichols 1998; Petroni 1992), and deferred tax valuation allowances.

\subsubsection{Socio-political incentives}

Culturally diverse views on macro governance as a desirable mode of governance date from antiquity. The scholastic debate over the optimal mechanisms of social order has not subsided since. Collectively referred to as "social institutions" (or simply "institutions"), macro governance, together with accountability and curbing corruption, are considered primary mediators for development. ${ }^{7}$ These principles are the central tenets in international institutions' policies on "good governance" and “empowerment” (IMF 1997; World Bank 2000 and 2001). International bodies are careful to acknowledge that reform programs need to be attentive to broader countrylevel governance yet fail to specify ways to achieve this goal. The social, cultural, political, legal and economic environment that is broader governance affects the accounting accrual choices of a firm. Accounting literature provides evidence that social values are reflected in accounting values (Pourgalali and Meek 1995). Accounting practices (or accounting values) are affected by cultural and social values. Different accounting practices result in different choice of accounting

\footnotetext{
${ }^{7}$ The literature on this subject is burgeoning. For sample works, Kufamnn et al. (1999); Knack and Keefer (1995); La Porta et al. (1997a); Hall and Jones (1999); Mauro (1995 and 1997) and Easterly and Levine (2002).
} 
accruals. As a result, this study proposes that accounting values affect the choice of earnings management. For example, countries with a high degree of conservatism may choose income decreasing accruals more often than those with a low degree of conservatism. On the other hand, if a country is ranked high in secrecy, then the accounting information systems would provide a greater chance for earnings management since managers are not required to disclose as much information as managers of countries that are ranked low in secrecy. Socio-political incentives on earnings management can be classified into five categories:

\subsubsection{Degree of enforcement}

In principle, a strong system of legal enforcement could substitute for weak rules since active and well-functioning courts can step in and rescue investors from the adverse effects of management discretion. A legal system providing investor protection helps resolve agency problems (La Porta et al. 2000). Countries whose legal systems protect shareholders have relatively larger and broader capital markets (La Porta et al. 1997). La Porta et al. (1998) find evidence, based on 49 countries, that common law countries generally have the strongest investor protection while French civil law countries have the weakest protection with, German-Scandinavian civil law countries sitting in the middle. Countries with strong property laws and enforcement mechanisms facilitate informed arbitrage and capitalization of firm specific information (Morck et al. 2000). In response to the above studies, Shen and Chih (2005) used banking industry data to calculate earnings management across 48 countries based on the methodologies of DeGeorge et al. (1999) and Burgstahler and Dichev (1997). They find that the propensity to avoid small losses and report small 
increases in earnings is quite pervasive in the banking sector around the world. They also suggest that legal enforcement is a key factor in explaining variation in earnings management across countries.

Brown and Higgins (2001) compare the distribution of earnings surprises in the US to those of 12 other countries and provide evidence that US managers are relatively more likely to manage earnings surprises due to differences in US firmlevel governance and legal environments. The US ranks among the top of all countries in investor protection (La Porta et al. 1998). Managers who knowingly make misleading or false forecasts are subject to liability under both SEC Act of 1934 via Rule 10b-5 and the principles of common law. A typical 10b-5 lawsuit occurs after a steep stock price decline, where plaintiffs allege that they bought stock at inflated prices because managers either failed to disclose materially adverse information or disseminated overly optimistic information (Kellogg 1984; Francis et al. 1994).

The legal liability climate is more intense in the US than any other country due to the American rule and its uses of class action suits. The American rules require each party to bear its own costs, including litigation (Hughes and Snyder 1995). In contrast, the English rule, used in most of the Western world, requires losers to pay the winners legal fees, reducing the frequency of low-merit claims (Hughes and Snyder 1995). Legal liability is lower in France, Germany and Japan, whose judicial systems are less favourable to plaintiffs than are the US and the UK, and the legal risk is low (but increasing) (Frost 1999). Civil litigation is rare in continental European countries compared to the US and the UK (Ball et al. 2000). As a result, 
non-US managers providing negative earnings surprises face fewer, less severe legal expenses.

Following English rules, class action suits are generally not permitted in other common law countries (Romano 1993). Once a judge allows a case in the US to receive class action status, defendants often capitulate given the sheer number of plaintiffs. The rate of class action suits kept rising in the US despite laws to curb abusive litigation. Plaintiffs agree to settle less often than they used to, and they seek larger and larger percentages of recovery. After a stock drops, litigious shareholders seek to be appointed lead plaintiffs, as being so named means higher compensation.

\subsubsection{Institutional setting}

In general, a strong institutional setting facilitates reduced private benefits that insiders receive because of their affiliation with the corporation (Dyck and Zingales 2002). To understand this causal relation, consider directors' incentives in countries with weak institutional settings. A distinctive feature of such countries is that managers and directors (collectively known as insiders) receive large personal benefits from their controlling positions through various forms of self-dealing, such as additional stock issuance to insiders and sophisticated transfer pricing schemes (Shleifer and Vishny 1997). For example, in some countries it is common for corporations to routinely sell assets to insider-controlled companies at below-market prices and for corporations to purchase assets from insider-controlled vendors at above-market prices. Thus, directors in these countries frequently profit from their affiliation with the firm through activities that involve colluding with other insiders. Furthermore, because self-dealing is not consistent with profit maximization, the 
directors themselves are likely to bear at least partial responsibility for firms with poor earnings and stock price performance

Institutional weakness provides incentive for managing earnings. In the absence of strict enforcement of law, managers are more likely to engage in earnings management due to the low probability of being caught and low cost associated with being disciplined if caught. Peter (2004) recommends strengthening the institutional base and policy efforts to reduce insiders' private control and earnings management activities. Belkaoui and AlNajjar (2006) test the determinants of earnings opacity internationally. The determinants are hypothesized to be the elements of the social, economic and accounting order in each of the 34 countries of the study. They find that earnings opacity internationally is negatively related to the levels of economic freedom and quality of life, and positively related to the rule of law, economic growth and level of corruption. Further, the findings are surprising in that the level of disclosure, the number of auditors per 100,000 inhabitants and the adoption of international accounting standards (as elements of the accounting order) are not significantly related to earnings opacity internationally. It appears that the social and economic climate rather than the technical accounting climate is at the core of the lack of accounting quality in general and earnings opacity in particular. Soderstrom and Sun (2008) suggests that accounting quality is a function of the firms' overall institutional setting, including the legal and political system of the country in which the firm resides. 


\subsubsection{Political system}

Recent accounting scandals in countries across the globe have sparked strong reaction from shareholders and other parties against accounting quality. Dozens of high profile corporate failures that were somehow linked to accounting irregularities also discredited the accounting and auditing profession. Even prior to these recent collapses, the political system was viewed as one of the main obstacles facing postcommunist countries in attempts to establish democratic institutions and open, market economies (Shleifer and Vishny 1997). As yet there is limited knowledge about what causes accounting manipulation in one country to be higher than that in another. While theories abound and cross-country studies examining details of accounting manipulation in particular countries or regions are increasing in number, crossnational comparative empirical research is much rarer. The difficulty of measuring relative levels of perceived accounting quality in different countries has presented a major obstacle. Recently, however, economists and political scientists have begun to analyze indexes of 'perceived' accounting quality prepared by business risk analysts and polling organizations, based on survey responses of businessmen and local residents.

Why do managers in some firms misuse discretionary power for private gains more frequently, and for large payoffs, than do managers in others? The manager can be construed as balancing the expected cost of earnings manipulations, including psychological and social as well as financial costs, against expected benefits. Political scientists and economists have suggested a variety of characteristics of countries' economic, political, and social systems that might affect expected costs, benefits, or both. As rule of law is considered a precondition for democracy survival, democratic 
governance may constrain accounting manipulation, but corrupt managers have incentives to create barriers to democratic rule to perpetuate corrupt accounting practices. Regardless of the type of governance, the size of the government can contribute to corrupt accounting via the size and complexity of bureaucracy. The bigger the government, the bigger the power distance observed by Hofstede (1980). Therefore, corrupt managers have incentives to support a bigger government consistent with empire building behavior of underperforming managers.

Political instability may also enhance incentives (or reduce opportunities) for earnings management. This occurs because political unrest may divert peoples' attention to more pressing day-to-day issues instead of scrutinizing accounting irregularities. In addition, political instability means frequent changes in policies, and personnel in the functioning of institutions-all of which are conducive to a relatively easy pass with irregularities than in times of peace. It is therefore not surprising those countries that had seen democracies (by the classification of Alvarez et al. 1996) uninterrupted since 1950 tend to be perceived as less prone to earnings management.

The political culture of a country determines, to a large extent, the soundness of its business environment. In general, it is believed that a democratic system and the institutions that come along with democratic practices are conducive to businesses. Hence political stability works as an antidote for political risk, which, in turn, attracts investment to the country boosting its capital market. Under democracy, regulators are likely to have more power in performing their oversight function as the government of the day has incentives to be seen as performing in the best interest of the investors and businesses. On the other hand, governments of autocratic regimes do not necessarily consider themselves accountable to the people and are more likely 
to discriminate in enforcement of the law, allowing its supporters to engage in accounting irregularities including earnings management. Nevertheless, it is acknowledged that autocrats could be argued to have incentives to promote good governance to ensure that opposition to the regime does not easily gain popular support. Countries like China, Iran, and Myanmar provide examples of totalitarian models of governance with reasonably strict law enforcement.

\subsubsection{Perceived corruption}

Extant research suggests that the level of earnings management is positively related to the level of perceived corruption in the country. Today there is general consensus that corruption negatively affects organizations, economies and societies (Mauro 1995; Pierre and Sekkat 2005; Wei 2000). Hoopes et al. (2006) investigate the relationship between various measures of accounting and corruption, suggesting that better accounting and auditing quality can reduce corruption. A more specific example of the costs of corruption are provided by $\mathrm{Hu}$ (2000), who estimates the economic cost of corruption to the Chinese economy between 1995 and 1998 of between 13.2 and 16.8 percent of Chinas' GDP. Hall and Yago (2002) indicate, “A key reason for keeping transactions secret is to conceal corrupt practices. With transparency comes prying eyes." Theoretical scholars have suggested that there are three central elements to corruption (Jain 2001). Jain explains these three elements as:

"First, someone must have discretionary power...Second, there must be economic rents associated with this power...and third, the legal/judicial system must offer sufficiently low probability of detection and/or penalty for the wrong doing (Jain, 2001: 77)”.

Since, these three factors provide a basis for corruption, analyzing these elements could prove helpful in developing strategies to combat corruption. 
Furthermore, as Jain (2001) indicates, these elements of corruption can be broken into two parts; the first two requirements serve as incentives for corruption and the third requirement acts as a deterrent to corruption. Ades and Di Tella (1997) examine whether the possible benefits of interventionist industrial policies such as the promotion of investment or the support for research and development must be qualified in the presence of corruption. Using a large sample from surveys conducted amongst top managers and economic leaders in the surveyed countries over 19891992, they find that it is more expensive to achieve such objectives using active industrial policies in economies where corruption is widespread than in corruptionfree environments. On the other hand, Rock and Bonnett (2004) test the relationship between corruption, investment and growth during four different time periods 1980$83,1988-92,1984-96$ and 1994-96. They find that corruption is more damaging to investment and growth in small developing countries than in large ones. This is important because it tentatively suggests that the international institutions, regional development banks and bilateral aid donors might have more to gain by focusing their anti-corruption programs on small developing countries.

While corrupt politicians and government officials are the bribe-takers, it is often the private sector (especially the corporate sector) that offers the bribes (Vogl 1998; $\mathrm{Wu} 2005)$. The corporate sector is both the victim and perpetrator of corruption: while businesses are often subject to extortion from corrupt government officials, it is not uncommon to find that businesses themselves initiate the bribery deal in order to evade their responsibilities to the public or to undermine the efforts of their competitors. 
Corruption, regardless of the form it takes, usually involves a financial payment, inevitably leaving a paper trail behind in accounting records. Accountants and auditors are thus in a unique position to detect and prevent corrupt acts. In Asia, however, the accounting practices in many firms are often of low quality. On the one hand, firms may find it convenient to have murky accounting practices because they can easily tamper with their accounting books to evade extortion or to shield themselves from unfair discrimination by the government. On the other hand, bad accounting practices also make it difficult to detect and prevent other business flaws that are detrimental to the firms.

\subsubsection{National culture}

Accounting literature provides evidence that social values are reflected in accounting values or numbers (Pourjalali and Meek 1995; Chow et al. 1999). Extant research suggests that culture has been shown to influence corporate financial and operating strategies (Schuler and Rogovsky 1998) and impact accounting choices that is earnings management (Nabar and Boonlert 2007; Guan et al. 2005). In accounting literature, Gray (1988) was the first to theorize that national culture influences countries' adoption of accounting systems and values. He suggested that accounting values are derived from cultural values and by the way cultural values would affect various accounting decisions and choices, including managers' tendencies to manage earnings. Subsequent studies (Salter and Niswander 1995; Hope 2003) examine the effect of culture on accounting system attributes such as authority, enforcement, measurement and disclosure. Elias (2004) empirically investigates the relationship between corporate ethical values and earnings management. The results indicate that 
CPAs employed in organizations with high (low) ethical standards view earnings management activities as more unethical (ethical). The impact of culture on earnings management, however, has received limited attention.

In this review, this study conjectures on the possible link between Hofstede (1980) cultural dimension and earnings management. Hofstede proposed four dimensions of societal values: uncertainty avoidance, individualism, power distance, and masculinity. Uncertainty avoidance implies a preference for unambiguity. Gray (1988) argues that strong uncertainty avoidance leads to a preference for conservative measurement. Since earnings management typically implies the use of aggressive accounting techniques, an extension of Gray's (1988) hypothesis would suggest a negative association between uncertainty avoidance and earnings management. Doupnik and Tsakumis (2004), however, contend that the impact of culture on conservatism has not been empirically established. Moreover, the relationship between uncertainty avoidance and earnings management could be positive for the following reasons. Strong uncertainty avoidance could lead to a demand for earnings smoothing and earnings signalling, both of which can be achieved through earnings management. Second, recent finance and accounting research has demonstrated that in the US, managers strive to meet or beat earnings thresholds (DeGeorge et al. 1999), that investors reward firms that consistently report increasing earnings (Barth et al. 1999), and that firms reporting negative earnings surprises bear a relatively high cost of equity capital (Mikhail et al. 2004). If these rewards and penalties are high in strong uncertainty avoidance countries, because people value consistency in firms' earnings streams, then managers in such countries are likely to manage earnings. 
Hofstede (2001) asserts that highly individualistic societies are characterized by self-orientation, autonomy, low-context communication, and emphasis on individual achievement. Schuler and Rogovsky (1998) find that individualism is positively associated with the use of pay-for-performance contracts. Thus, personal gain is likely to be an important motivator in high individualism societies. Prior research on earnings management (Beneish 1999) suggests that managers misstate earnings to maximize their own wealth, often at a significant cost to other stakeholders in the firm. Concern for other stakeholders' welfare is indicative of collectivism, not individualism. Accordingly, earnings management is likely to be high in highly individualistic societies.

High power distance implies that decision structures in organizations are centralized and the authority is concentrated in the hands of the top managers (Hofstede 2001). High power-distance countries are characterized by the lack of both leader communication (Offerman and Hellman 1997) and participative leadership (House et al. 2004). Prior research indicates a high incidence of earnings management when top managers are powerful. For example, Dechow et al. (1996) find that earnings management is prevalent in firms in which the chief executive officer also either serves as chairman of the board or is the firms' founder. Gray (1998) also argues that information sharing is low in high power-distance societies.

Masculinity indicates a preference for achievement, assertiveness and material success. In high-masculinity societies, according to Hofstede (2001), desirable managerial qualities include decisiveness and competitiveness. The society places high emphasis on performance, and managers hold ambitious career aspirations, preferring to work for prominent companies and earn high salaries. Masculinity has 
also been shown to be positively associated with society's acceptance of aggressive behaviour and consumers desire to keep up appearances (Hoopes et al. 2006). This suggests that managers in high-masculinity societies are likely to endeavor to report strong profits that beat benchmarks.

\subsubsection{Capital market incentives}

One of the most important factors motivating managers to engage in earnings management is the existence of asymmetric information. Berle and Means (1932) suggest that in the widely held corporation, the risk bearing function of ownership and the managerial function of control are separate functions performed by different parties. This causes the classic principal-agent problem between owners and managers where, given the decision making discretion, managers could engage in non-value maximizing behaviours (Jensen and Meckling 1976). In this dispersed ownership scenario, managers have the incentive to engage in earnings management because (i) the existence of information asymmetry makes it difficult for outsiders to undo the effect of earnings management and (ii) managers usually own a very significant fraction of corporate wealth. Capital market-based earnings management incentives can be classified into three categories:

\subsubsection{Avoidance of reporting loss or earnings decrease}

Extant research suggests that managers have strong incentives to avoid reporting earnings decreases and losses. Barth et al. (1999) report that firms with a consistent pattern of earnings increases command higher price-earnings multiples. DeAngelo et

al. (1996) document that firms breaking a pattern of consistent earnings growth 
experience an average of $14 \%$ negative abnormal return in the year the pattern is broken. Hence, managers may manage earnings upward to avoid reporting earnings decreases and losses if the pre-managed earnings level is below the previous years' earnings.

There is a considerable literature that suggests that managers in the USA and the UK manage earnings to meet or beat targets. This is understandable because stock prices react to unexpected earnings surprises and hence managers have incentives to provide positive earnings surprises to the market. Further, substantial stock options granted to US and UK managers exacerbate this situation because managers are more likely to inflate earnings numbers to boost stock prices, and then exercise their options to make windfall gains.

Another reason why managers tend to manage earnings is analysts' forecasts. They do so because the market tends to penalize firms heavily for missing earnings targets issued by analysts. Myers and Skinner (1999) provide evidence that managers of firms with a long series of consecutive increases in quarterly EPS manage earnings. This is because these firms tend to have high stock market valuations relative to accounting metrics such as earnings and book values and if their earnings growth stops the market penalizes them severely.

Burgstahler and Dichev (1997) provide evidence that earnings are managed to avoid earnings decreases and losses. Over the period 1977-1994 they show histograms of the scaled earnings changes for 64,666 firm-year observations and find unusually low frequencies of small decreases in earnings and small losses and unusually high frequencies of small increases in earnings and small positive income. With respect to avoiding reporting losses, Hayn (1995) notes that: 
Interestingly, there is a point of discontinuity around zero. Specifically, there is a concentration of cases just above zero, while there are fewer than expected cases... of small losses (i.e. just below zero). The frequency of observations in both the region just above and that just below zero departs significantly from expected frequency under the normal distribution at the 1\% significance level using the binomial test. These results suggest that firms whose earnings are expected to fall just below the earnings point engage in earnings manipulations to help them cross the 'red line' for the year.

This tendency of focusing on thresholds is termed 'threshold mentality' by DeGeorge et al. (1999). They identify three thresholds that help drive earnings management: the first is to report profits. The second and third benchmarks rely on performance relative to widely reported firm specific values, e.g. (i) performance relative to the prior comparable period and (ii) relative to analysts' earnings projections. DeGeorge et al. (1999) elaborates on why this threshold mentality is exhibited by corporate executives. They explain that:

The salience of thresholds arises from at least three psychological effects. First, there is something fundamental about positive and non-positive numbers in human thought processes...when looking at the benchmark of quarterly earnings a year back and the analysts' consensus forecast, there is a salient dividing line between meeting and failing to meet the norm....Second, individuals choosing among risky alternatives behave as if they evaluate outcomes as changes from a reference point [prospect theory version]. The reference point is usually some aspect of the decision makers' current state (e.g. wealth), and it shifts over time, sometimes with how the decision is framed...... If the preferences of executives, the boards that review them, or the investors who trade the firms' stock are consistent with the predictions of prospect theory, then executives will have a threshold related reward schedule and are likely to manage reported earnings in response.... Third, thresholds come to the fore because people depend on rules of thumb to reduce transactions costs... Banks, for example, may grant loans only to firms that report positive numbers; that is banks use a threshold of zero earnings as an initial screen.

Using 5,387 firm year observations over the period 1974-1996, the authors provide convincing evidence that managers manage earnings to meet thresholds with positive profits (avoiding losses) receiving top priority among the thresholds. Burgstahler and Dichev (1997) also find that managers manage earnings to report earnings increases as well as to avoid reporting losses. But according to Dechow et al. (2003) the evidence provided by Burgstahler and Dichev (1997) in support of 
earnings management is not that strong. Burgstahler and Dichev (1997) show an increase in the level of cash flows manipulation to boost earnings and that median change in working capital accruals slightly increase at the zero earnings benchmark. But Dechow et al. (2003) argue that these are not convincing arguments in favour of earnings management because:

..... given the well-known positive relation between cash flows and earnings, an increase in cash flows is expected around the kink.... Increase in median change in working capital]... is not surprising since there is a well known positive relation between working capital accruals and earnings.

Using 47,847 firm year observations from 1988-2000, they fail to find any convincing evidence that earnings management drives the discontinuity around zero earnings reference point since small profit firms and small loss firms both make income-increasing discretionary accruals choices.

Thus even though an empirical examination of the distribution of earnings level and changes around a benchmark of zero provides an insight into earnings management behaviour, other explanations are also plausible. Habib (2005) finds 46 firms from a sample of 107 firms in Bangladesh engage in at least one form of earnings management practice or other. Further a logistic regression result indicates that small firms and firms with high sponsor ownership are more likely to engage in earnings management practices. Also, firms having a higher debt equity ratio tend to engage more in earnings management. Kerstein and Rai (2007) test the upward earnings management which causes the kink and indicates which firms are likely to manage earnings upward. Using data from 1976-2005, they find that a high proportion of firms with small cumulative profits or losses at the beginning of the fourth-quarter, report small annual profits rather than small annual losses. Petrovits 
(2006) examines the strategic use of corporate philanthropy programs to achieve financial reporting objectives. The result indicates that firms reporting small earnings increases make income-increasing discretionary foundation funding choices.

\subsubsection{Capital market transaction incentives}

Another incentive for earnings management arises from capital market transactions such as initial public offerings (IPO) or seasoned equity offerings (SEO). Since management would like to maximize the proceeds from IPOs and SEOs, and one of the metrics that investors use in deciding whether to subscribe for the issue is likely to be the past earnings series, managers might manage earnings upward through accruals manipulation.

The poor stock price performance of firms that raise capital through seasoned equity offerings is one of the important anomalies of the market. Loughran and Ritter (1995) and Spiess and Affleck-Graves (1995) document that firms under-perform in the five years after a seasoned equity issue. For example, Loughran and Ritter report average annual return of only $7 \%$, while comparable non-issuing firms average $15 \%$ per year.

Teoh et al. (1998a) examine whether unusually aggressive earnings management through income increasing accruals adjustments leads to the post-issue under-performance. They note that:

..... investors may misinterpret high earnings reported at the time of the offerings, and consequently overvalue the new issues. When high pre-issue earnings are not sustained, disappointed investors subsequently revalue the firm down to a level justified by fundamentals. This earnings management hypothesis predicts that issuers have unusually high-income increasing adjustments preissue and unusually poor earnings and stock return performance post-issue. Further, the hypothesis predicts worse performance for issuers with unusually large income-increasing accounting adjustments prior to the offerings. 
Using 1,265 seasoned equity offering observations over 1976-1989, Teoh et al. (1998a) report that, the annual growth in the issuers' asset-scaled net income exceeds that of the matched non-issuers by a median of $1.60 \%$ and $0.32 \%$ in the two subsequent years. With respect to discretionary accruals they find that, in the year of offering, the asset scaled discretionary current accruals of issuers exceed their preissue performance matched industry peers by 2.9\%. Rangan (1998) investigates whether earnings management around the time of seasoned equity offerings can explain why firms conducting such offerings experience subsequent price and earnings performance. For a sample of 230 seasoned offerings from the years 19871990, Rangan finds median discretionary accruals scaled by beginning total assets to be $0.83 \%$ in the quarter of offering announcement and $1.15 \%$ in the following quarter, which are statistically significantly different from zero.

On the question of when the manager should start managing earnings given a decision to make a seasoned equity offering, Rangan (1998) hypothesizes that:

If the decision is to issue equity and the public announcement of the offering is within a quarter of each other, the earliest quarter in which earnings management is likely to occur is the quarter immediately preceding the offering announcement. If their decision to issue equity occurred well before the announcement of the offering, the manager would choose to manipulate earnings and influence investors' expectations over an extended time before the offering announcement. Even in this case, the incentives to manipulate will be strongest in the quarter immediately preceding the offering announcement, because this is the quarter in which they would want the firm to be most over valued.... I expect that managers will continue to manage earnings in the quarters after the offering announcement for two reasons. First, an earnings reversal immediately after the offering and the associated price drop could participate lawsuits against the firm and its manager..., second, firms enter into "lock up agreements" with their underwriters that prevent insiders at issuing firms from selling their holdings until 90 to 180 days after the offering date.... Insiders who wish to sell shares at the end of this lock-up period clearly have incentives to support the stock price.....

Shivakumar (2000) proposes a non-opportunistic motive for earnings management, and challenges the frequently articulated view that earnings 
management around corporate events is synonymous with managerial opportunism. Islam et al. (2002) investigate the operating performance of firms conducting SEOs in Bangladesh. However, they do not examine the behaviour of accruals and discretionary accruals in particular. Teoh et al. (1998b) examine managerial incentives to manipulate earnings during IPO process. Using a sample of 1,649 domestic IPO firms in the period from 1980-1992, they find that discretionary accruals scaled by prior year total assets, in the year of going public was $4.01 \%$ while it was $2.24 \%$ in the year following the issue. It then declines monotonically over time and reaches a level insignificantly different from zero by year 3. Yoon and Miller (2002) find that seasoned equity offering firms manage earnings in the year before a planned issue of seasoned equity stocks. Using a sample of 249 Korean listed firms that issued seasoned equity stocks from March 1995 to December 1997, the results support the earnings management hypothesis for the negative operating cash flow firm.

\subsubsection{3 'Beat or meet' forecasts}

Heightened capital market pressure has created additional incentives in recent years for managers to engage in earnings manipulation. Firms have to operate under constant pressure to meet market expectations to maintain desired levels of market value. Financial analysts regularly release earnings forecasts that become unofficially binding on the firms to meet. Even narrow misses of analysts' forecasts can be costly. Therefore, firms may resort to adoption of discretionary accounting policies to produce income numbers that save them from missing the earnings benchmarks set by the market. One common measure that firms appear to be anxious to maintain in 
line with market expectations is earnings per share (EPS). Analysts make quarterly forecasts of EPS, revenue, revenue growth, and EPS growth. For publicly traded firms with analyst following, such forecasts increasingly dictate managers' choice of accounting policies. Burgstahler and Eames (2006) find that managers take actions to manage earnings to avoid reporting earnings lower than analysts`expectations. Kasznik (1999) finds evidence that firms whose managers have overestimated earnings (44\% of the sample) [forecasted EPS > actual EPS] have significant levels of positive discretionary accruals. Kasznik (1999) interprets this finding as evidence that managers manage reported earnings toward their forecasts. Brown (2001) provides evidence that the proportion of time that earnings exactly meet or just exceed analysts` forecasts has increased over time while the proportion of near misses has declined. He also documents that the trend is most pronounced for growth stocks, which are more sensitive to negative earnings surprises. Hribar et al. (2006) investigate whether firms use stock repurchases to meet or beat analysts' earnings per share (EPS) forecasts. Using a 13-year sample period from 1988 to 2001, they find that a disproportionately large number of firms with EPS increasing stock repurchases would have missed analysts' forecasts but for the repurchase. The repurchase-induced component of earnings surprises appears to be discounted by the market, and this discount is larger when the repurchase seems motivated by EPS management, although using the repurchase to avoid missing analyst forecasts appears to mitigate some of the negative stock price response. 


\subsubsection{Contractual incentives}

Organisations often enter into complex contracts with various stakeholders such as lenders and employees (e.g. senior executives). These contracts typically include specific clauses binding the organisation with certain accounting numbers such as requiring the organisation to maintain a specified interest coverage ratio, a maximum allowable level of leverage or a minimum level of liquidity. For example, at the time

of issuing bonds, obtaining a loan, arranging a mortgage to finance acquisition of an item of PPE, arranging a lease of a major asset, negotiating employee bonuses or issuing stock options, organisations sign contracts with concerned counter-parties obliging themselves to maintain certain levels of earnings, debt, assets, or equity. Breaches of these covenants can be costly. Therefore, when they are close to breaching any such covenant, managers have incentives to use accounting discretion to prevent possible breach. In the earnings management literature, two forms of contracting motives have been investigated: debt contracts and performance based compensation contracts.

\subsubsection{Debt contracts}

Another incentive that motivates managers to engage in earnings management arises when debt-covenants are written in terms of accounting numbers. If violations of debt-covenants are costly then managers will attempt to make income-increasing accounting accruals to avoid violating debt covenants with the assumption that lenders will fail to detect their actions. Watts and Zimmerman (1986) articulate this in their "debt/equity" hypothesis in the following words: 
Debt/equity hypothesis: Ceteris paribus, the larger a firms' debt/equity ratio, the more likely the firms' managers are to select accounting procedures that shift reported earnings from future periods to the current period.

The optimal way of investigating this hypothesis would be to (i) collect a comprehensive sample of actual debt covenants; (ii) identify the restrictions (imposed by lenders) that are written in terms of accounting numbers; (iii) determine the borrowers' proximity to violating such covenants; and finally, (iv) determine managers' accruals choices. However, Watts and Zimmerman (1986) observe that accrual testing simply relies on finding out the relationship between existence of long-term debt in the financial statements and managers' accruals choices. They note that:

Just as early researcher(s) chose to investigate the bonus hypothesis rather than hypotheses based on the details of bonus plan, they also chose to investigate a simple debt contract hypothesis rather than hypotheses based on the details of debt covenant. Bonus plan and debt covenant details are costly together, and simple hypotheses such as the bonus plan hypotheses are one way to see whether incurring that cost is likely to pay off. Watts and Zimmerman (1986: 378)

DeFond and Jiambalvo (1994) examine abnormal accruals of a sample of 94 firms that disclosed debt covenant violations during fiscal years 1985-1988. Both time-series and cross-sectional models indicate that abnormal total and working capital accruals are significantly positive in the year prior to violation. They hypothesize that if debt covenant restrictions influence accounting choices, the influence will be manifested in the year preceding and the year of violation of the relevant debt covenant. They find mean (median) discretionary accruals of 0.034 (0.029) in the year before violation, and both these values are significantly different from zero at better than the 5\% level. This, according to the authors, suggests earnings manipulation. However, in the years of violation, mean (median) discretionary accruals are reported to be $-0.043(-0.020)$ which are significantly 
different from zero at better than the 5\% level. As theory suggests a positive DACCR value in the year of violation, they control for management changes and going concern qualifications and report a mean (median) DACCR of 0.008(.011) though these are not statistically significant.

Paek and Press (1997) argue that if income-increasing accruals succeed in reducing potential re-contracting costs with debt holders, this will enhance share value and stock prices should be positively associated with accrual decisions that lessen the expected costs of violating debt covenants. Regressing annual stock returns on leverage and interaction of leverage and DACCR after controlling for cash flow and accrual components of earnings, authors report a regression coefficient of the interaction term of 0.063 for the entire sample and 0.11 for the positive DACCR sample. Although the former was not statistically significant, the latter was at 5\% level.

\subsubsection{Performance based compensation contracts}

A number of studies have examined actual compensation contracts to identify managers` earnings management incentives. On balance, the evidence reported in these studies is consistent with managers using accounting judgment to increase earnings-based bonus awards (Healy 1985; Holthausen et al. 1995; Jenkins 2002; Hanlon et al. 2003; Core et al. 2003 McVay 2006). This phenomenon is captured in Watts and Zimmerman's (1986) bonus plan hypothesis. Bonuses could be important, because executives subject to large bonuses have increased incentives to meet bonus targets. Bonus targets typically are based on a specific definition of earnings, which means that executives would tend to focus on that specific target. Consequently, if the 
target is based on some definition of income from current operations (above the line), earnings management strategies are expected to dump losses as nonrecurring items (below the line).

Other evidence supporting the management compensation theory can be found in the research of Dechow and Sloan (1991), who finds that managers decrease research and development expenditure in the final year of their terms in order to increase earnings and thus their payout, upon leaving the company. Meek et al. (2007) examine the factors affecting the relationships between CEO stock option compensation and earnings management. They find that a positive relationship between CEO stock option compensation and discretionary accruals implies that earnings management is more likely where stock options are a larger part of CEO compensation. Earnings management is found to be moderated in large firms with stock option compensation and the relationship between stock options and earnings management has intensified in recent years. It was also found that stock options exacerbate earnings management in firms with growth opportunities. Weber (2006) investigates whether executive wealth sensitivity to stock price fluctuations serves as an incentive for earnings management. Using a sample of 410 chief executive officers (CEOs) from 475 randomly selected Standard and Poor's (S\&P) 1500 firms, they find that CEO wealth sensitivity is positively associated with abnormal accrual usage and the relation is consistent with income-smoothing. They also find that governance does not significantly influence the association between CEO stock-based wealth sensitivity and earnings smoothing. 


\subsubsection{Regulatory incentives}

Healy and Wahlen (1999) identify two forms of regulation that have been investigated in earnings management literature so far. They are: industry-specific regulation and anti-trust regulation. It is argued that firms have incentives to use accounting to circumvent industry regulations such as the maintenance of specific levels of assets against specified levels of lending in the banking industry. Banking regulations in most countries require that banks maintain a specific level of equity against their lending activities. Banks are also required to observe specified levels of liquidity against deposits before lending part of the money received as deposits. To evade industry regulations, accounting standard setters have demonstrated an interest in earnings management. In fact, the shifts toward fair value accounting and increased risk-related disclosures (as well as specific changes in regulatory accounting standards for lending and other financial institutions) were initiated due to the financial chaos in the savings and loan industry in the U.S.A in the 1980s. These accounting changes were planned, at least in part, to alleviate earnings management, provide information for stakeholders, and improve decision-making by bank regulators. Standard setters may also be interested in earnings management for antitrust purposes. Evidence on both of these earnings management motives is provided below:

\subsubsection{Industry-specific regulation}

Banking regulations typically require banks to maintain a certain amount of capital, called capital adequacy requirements. Similarly, insurance regulations require that insurers meet certain conditions to maintain a minimum financial soundness. Finally, 
utilities have historically been rate-regulated and permitted to earn only a normal return. It is frequently emphasized that such regulations create incentives to manage financial statement variables of interest to regulators (Healy and Wahlen 1999). A number of studies provide evidence consistent with this hypothesis.

There is significant evidence that banks that are close to minimum capital requirements overstate loan loss provisions, understate loan write-offs, and recognize abnormal realized gains on securities portfolios (Moyer 1990; Scholes et al. 1990; Beatty et al. 1995; Collins et al. 1995). There is also evidence that financially weak property-casualty insurers that risk regulatory attention understate claim loss reserves (Petroni 1992) and engage in reinsurance transactions.

From a regulatory view point, a number of studies provide evidence on the frequency which firms engage in earnings management. Collins et al. (1995) develop regulatory capital requirement scores for sixty sample banks based on tests of seven possible capital management options. They find that no banks have a maximum score of seven but 10 banks have a score of 6 and 19 banks have a score of 5 . In sum, nearly half of their sample banks appear to use five out of seven possible options to manage regulatory capital requirement. Adiel (1996) examines data for 1,294 insureryears in the period 1980 to 1990 and reports that for $1.5 \%$ of the sample insurer-years financial reinsurance appeared to be used to avoid failing regulatory tests.

\subsubsection{Anti-trust and other regulations}

Managers vulnerable to anti-trust investigations or other adverse political consequences have incentives to manage earnings to appear less profitable and/or seek government subsidies or protection (Watts and Zimmerman 1978: 378). Cahan 
(1992) explains that firms under investigation for anti-trust violations reported income-decreasing abnormal accruals during investigation years. Jones (1991) found that firms in industries seeking import relief tend to defer income in the year of application. Key (1997) examines unexpected accruals for firms in the cable television industry at the time of Congressional hearings considering deregulation of the industry. Her evidence is consistent with firms in the industry deferring earnings during the period of Congressional scrutiny. In order to avoid adverse political visibility, firms enjoying monopoly, oligopoly, monopolistic or oligopolistic competition also have incentives to appear less profitable. By appearing less profitable, they try to avoid political costs. Firms that are politically visible-due to their monopoly status, for being too large and/or having a reputation of making unreasonably high profits, or being in a politically sensitive industry, e.g. healthcare, water or energy - have incentives to resort to 'legitimate' accounting manipulations to avoid political scrutiny. Political cost hypothesis states that political pressure to reduce prices or face penalties which may result from investigations of firms which are suspected of breaching anti-trust rules or otherwise taking advantage of the general public may create incentives for firms to manage earnings (Fong 2006). Han and Wong (1998), for instance, find that firms who expected to profit from the price increases during the 1990 Gulf War managed their accruals so as to reduce earnings and avoid political scrutiny.

In sum, the earnings management studies suggest that regulatory considerations induce firms to manage earnings. However, there is limited evidence on whether this behaviour is widespread or rare, and very little evidence on the impact of regulators. 


\subsubsection{Industry sectoral differences}

The dual economy theory hypothesizes that as periphery sector firms face a stronger degree of environmental uncertainty and a more restricted opportunity structure, they are more likely to engage in earnings management than those in the core sector (Belkaoui and Picur 1984). Averitt (1968) defines the American Economy as 'a composite of two business systems' that later came to be called the core and the periphery. Moreover, Bluestone et al. (1973) define core economy sector firms as big in size, with high productivity, high profits, capital intensive, enjoying a high incidence of monopoly elements, and a high degree of unionization. In contrast, the periphery sector firms are noted for their small size, high labour intensity, low profit, low productivity, intensive product market competition, lack of unionization, and low wages. Beck et al. (1978) test the definition by classifying companies as core or peripheral on the basis of their two-digit SIC codes and find that core-firm labour characteristics differ from those of periphery-firm ${ }^{8}$. Rath and Sun (2007) concur with Belkaoui and Picur (1984) that those firms in the periphery sector are more likely to exhibit greater degrees of earnings management than firms in the core sector. However, based on the sample of 256 U.S firms, Albrecht and Richardson (1990) find no support for the Belkaoui and Picur hypothesis. Kinnunen et al. (1995) find that both potential and actual earnings management are significantly larger in the core

8 Under Beck et al. (1978) classification, Mining, Construction, Durable/Nondurable Manufacturing, Transportation, Communications, Utilities and Sanitary Services, Wholesale Trade, Finance, Insurance, and Real Estate, Professional and Related Services, and Public Administration are classified as core sector. Agriculture, Forestry, and Fisheries, Miscellaneous Durable/Nondurable Manufacturing, Not Specified Nondurable Manufacturing, Retail Trade, Business and Repair Services, Personal Services, Entertainment and Recreation Services are classified as periphery sector. 
sector. Jones and Sharma (2001) report significantly lower frequency of earnings management in the "new economy" firms compared to counterparts".

\subsubsection{Adoption of IFRS}

The goal of the International Accounting Standards Board (IASB), and its predecessor body, the International Accounting Standards Committee (IASC), is to develop a single set of high quality financial reporting standards. To achieve this goal, the IASB (and IASC) has issued principles-based standards, and has taken steps to remove or narrow down allowable accounting alternatives and to require accounting measurements (i.e. fair value) that better reflect firms' economic performance and position. Accounting quality could improve if these actions by standard setters limit managements' opportunistic discretion in determining accounting numbers. Accounting quality also could improve because of changes in the financial reporting framework contemporaneous with firms' adoption of IAS e.g. from more rigorous enforcement.

Adopting IFRS would be expected to reduce information asymmetry between managers and shareholders. Barth et al. (2006) suggest that firms that adopt IFRS are less prone to engage in earnings smoothing and are more likely to recognize losses in a timely manner. However, contrary to Barth et al. (2006), van Tendeloo and Vanstraelen (2005), Lin and Paananen (2007) examine discretionary accruals of German firms adopting IFRS and find that IFRS firms have more discretionary accruals and a lower correlation between accruals and cash flows. Paananen (2008)

9 The 'new economy' is defined by Lev (2000) discussion Paper "New Accounting for New Economy" suggests that 'new economy' refer to those firms with high growth, negative income and cash flows. 
investigates whether the quality of financial reporting in Sweden increased after the adoption of IFRS and finds that the quality of financial reporting (measured as smoothing of earnings) decreased after the adoption of IFRS. Platikanova and Nobes (2006) compare the information asymmetry component of the bid-ask spread among companies before and after EU's adoption of IFRS in 2005. They find a larger volatility in the information asymmetry for UK and German companies. Contrary to expectations, they also find that companies from countries where earnings management is more common exhibit a lower information asymmetry component compared to other groups of countries. They interpret this result as indicating that income smoothing reduces information asymmetry. Ball et al. (2003) argue that adopting high quality standards might be a necessary condition for acquiring high quality information, without being a sufficient one.

\subsection{Constraints on earnings management}

The Berle and Means (1932) model of corporate governance depicts firms as owned by dispersed shareholders, who lack the ability, skill and incentives to monitor manager performance. As ownership is separate from management, information is distributed asymmetrically (Greenwald and Stiglitz 1990). Managers, who are better informed than shareholders about business prospects, shift earnings from a future time period to the current one (Jacobson and Aaker 1993). Investors are aware of this, but they are unable to determine its extent, pressuring all managers to emphasize current-term results. The information asymmetry leaves investors unaware of longterm value enhancing options, and induces them to attach more importance to current term results than they otherwise would. 
The agency problem in the diffused-ownership corporation is to minimize the sum of costs of aligning managers and shareholders incentives (Jensen and Meckling 1976). Corporate governance mechanisms can reduce agency problems, but managers focus on short term performance due to information asymmetries. The three most important corporate governance mechanisms in the US reflect a focus on current stock price: Independent directors, the market for corporate control, and equity-based compensation to managers. German and Japanese firms, for example, have independent directors on their boards, but these relationships generally last a long time, placing less emphasis on short term performance (Kaplan 1994; Kaplan and Minton 1994). Unfriendly mergers and acquisitions rarely occur outside the US and the UK (Shleifer and Vishny 1997), and non-US managers are rarely compensated in stock and options (Share and Share 1999).

Independent directors are found to help mitigate agency costs (Bacon and Brown 1975; Gilson and Roe 1993). In the US, shareholders bridge their separation from managers by electing non-employee directors to stimulate and oversee competition among top performers (Fama 1980). These directors play an important monitoring role, as seen by higher CEO turnover for poorly performing firms with independent board members (Weisbach 1988). Non-US governance systems are less short-term oriented because their managers either are controlling shareholders or relationships between managers and stakeholders are maintained for a long time. In contrast, US managers stress short-term goals, such as achieving forecast profit (Eccles et al. 2001; Collingwood 2001). Peasnall et al. (2000) find that the likelihood of managers making income-increasing abnormal accruals to avoid reporting both losses and earnings reductions are negatively related to the proportion of outsiders on 
the board. Further tests indicate that this association is more pronounced in firms where the separation of corporate ownership and decision control is the greatest (i.e. where managerial equity ownership is very low). Chung et al. (2002) find that the presence of large institutional shareholding inhibits managers from increasing or decreasing reported profits towards managers' desired levels of profits.

The market for corporate control serves as a governance mechanism (Manne 1965; Jensen 1988), by removing poorly performing managers (Martin and McConnell 1991). Undervalued firms become acquisition targets (Pelapu 1986), creating market-induced incentives for managers to boost their firms' stock prices to retain their jobs. A popular way to boost stock prices is to play the earnings game, whose rules include creating small positive surprises and avoiding large negative ones (Brown 2001).

Executive compensation contracts, when combined with pressures of product and capital markets, monitor corporate managers (Hart 1983). In recent years, almost every large US firm has used equity as a management incentive whereas ten years ago only about half of all US firms did (Share and Share 1999). Japanese managers own much less equity (Lichtenberg and Pushner 1994), and stock option plans are uncommon (Aoki 1988). In many European countries, the heavy tax on option gains wiped out incentives to issue options so there was considerably less focus on current stock price and earnings (Foreign 1999).

Although it is expected that managers engage in earnings management, it is hypothesized that the degree of such behaviour would vary among companies due to the presence or absence of certain firm-specific characteristics. Managerial opportunism, whether in the form of expropriation of investors or misallocation of 
company funds, reduces the amount of resources that investors' are willing to put up to finance the firm. Firm-level governance deals with designing constraints that reduce the ex-post misallocation and thus induces investors to provide more funds $e x$ ante (Shleifer and Vishny 1997: 773).

Firm-level governance may take the form of internal and/or external mechanisms. Internal mechanisms could include adopting a dispersed ownership structure, taking measures to enhance board independence, instituting audit committees, and employing high quality auditors. Conversely, external mechanisms may include an active external takeover market, shareholder-friendly legal arrangements (soft infrastructure). Firm-level governance attributes are useful in signalling to shareholders the potential for managerial manipulations (Basley 1996; Dechow et al. 1996) that could be expected or tolerated within the firm. Ebrahim (2007) examines the relation between earnings management behaviour and the activity of both the board and audit committee. They find that earnings management is negatively related to both board and audit committee independence. Such negative relation is stronger when the audit committee is more active.

Becker et al. (1998) and Chen et al. (2005) report that Big 5 audit firms allow less income-increasing discretionary accruals choices compared to their non-big 5 counterparts. Liu and Lu (2002) find that the earnings management endeavours of managers in China are constrained to a certain extent when the firms are dominated by outside directors and when firms have shares traded by foreign investors. Their sample consists of 894 firms listed on Shanghai and Shenzen stock exchanges in 2002. Bloomfield and Shackman (2008) provide empirical evidence on the impact of non-audit services (NAS) as well as other firm characteristics on auditor 
independence by testing the relationship of NAS fees to the occurrence of financial statement restatements. They find evidence that the level of total fees paid to the audit firm is significant in the prediction of a restatement. In addition, the study also finds conclusive evidence of a negative association between audit firm industry specialization and a positive association to Big 5 audit firms. Caramanis and Lennox (2008), and Lin et al. (2006) test the greater audit effort to reduce the extent to which managers report aggressively high earnings. They suggest that low audit effort increases the extent to which managers are able to report aggressively high earnings. Chia et al. (2007) and Johl et al. (2007) examine the effect of the choice of auditors in constraining earnings management within a rule-based reporting framework during the Asian financial crisis and suggested that service-oriented companies engage in income decreasing earnings management during the crisis period. More importantly, the results indicate that only the Big-6 firms are able to significantly constrain the earnings management of managers of such companies.

Rahman and Ali (2006) investigate the extent of the effectiveness of monitoring functions of the board of directors, audit committee and concentrated ownership in reducing earnings management. Using a sample of 97 firms listed on the Main Board of Bursa Malaysia over the period 2002-2003, they find that earnings management is positively related to the size of the board of directors. The study also finds that ethnicity (race) has no effect in mitigating earnings management, possibly due to the more individualistic behaviour of the Bumiputra directors. The modernisation of Malaysia and also the increase in Bumiputra ownership of national wealth may have caused the Malays to be more individualistic, similar to their Chinese counterparts. 


\subsection{Summary}

This chapter presents a comprehensive review of earnings management literature relevant to the present study. Specifically, it identifies two streams of research that have considerable attention on the nature and direction of macro and micro governance on earnings management relationship namely, incentives for earnings management and constraints on earnings management. The diversity of the empirical findings is due to the differences in methodological choice, assumptions, hypotheses adopted, sample size and variables selected etc. The effect of earnings management on macro and micro governance is an interesting research question not only from an academic perspective but also from a policy setting framework. Prior research has focused almost exclusively on understanding whether earnings management exists and why. The findings indicate that earnings management occurs for a variety of reasons, including to country level investor protection, to influence stock market perceptions, to increase managements' compensation, to reduce the likelihood of violating debt agreements, to avoid regulatory intervention, to sectoral differences and to IFRS adoption. A brief summary of empirical studies on earnings management is provided in Appendix C. 


\section{Chapter Three \\ Research Question Development}

\subsection{Introduction}

3.2 Macro governance and earnings management

3.2.1 Enforcement and earnings management

3.2.2 Institutional setting and earnings management

3.2.3 Political system and earnings management

3.2.4 Corruption and earnings management

3.2.5 Culture and earnings management

3.2.6 Adoption of IFRS and earnings management

3.3. Micro governance and earnings management

3.3.1 Initial public offerings and earnings management

3.3.2 Debt contracting and earnings management

3.3.3 Performance based compensation and earnings management

3.3.4 Audit quality and earnings management

3.3.5 Board size and earnings management

3.3.6 Board effectiveness and earnings management

3.3.7 Ownership concentration and earnings management

\subsection{Summary}




\subsection{Introduction}

The literature on macro and micro governance on earnings management reviewed in Chapter Three, has underlined the fact that most studies in this area focus on one or more aspects of the issue of earnings management without incorporating all of them in a single study. One possible reason that could explain this trend in literature is that earnings management research, like most other areas of accounting research, evolved in the Anglo-Saxon countries where variations in macro governance parameters are minimal across the countries concerned. A limited number of country-level variables such as code law versus common law or equity versus credit models have become relevant as the literature has expanded to cover the European markets. It was not until recently (Luez et al. 2003; Francis and Wang 2008) that earnings quality outside developed capital markets has drawn serious attention. Secondly, country-level metrics are unstable and often lack comparability and therefore are likely to have measurement errors posing a threat to model validity. Finally, there are multiple dimensions of the concept of macro governance and there is no well developed theory of macro governance that could explain variation in earnings management across countries. In the absence of a well developed theory predicting earnings quality from a political governance perspective, it is difficult to test any particular proxy for the effect of macro governance on earnings quality in multi-country studies of earnings management. Researchers thus look for multiple variables in cross-country research to achieve greater confidence if results are consistent across alternative proxies and across studies.

This chapter is structured as follows: Section 3.2 describes macro governance and earnings management research questions for empirical specification of the study 
along with their economic rationale. Section 3.3 presents the micro governance and earnings management research questions along with their economic rationale. Finally, Section 3.4 provides a summary of the chapter.

\subsection{Macro governance and earnings management}

Luez et al. (2003) show that, firms in countries with developed equity markets, dispersed ownership structures, strong investor rights, and strict legal enforcement engage in less earnings management. Leuz et al. (2003) argue that strong and wellenforced outsider rights limit insiders' acquisition of private benefits of control commonly achieved through the use of corporate resources to pay for perquisites of the controlling party (Dyck and Zingales 2004). This mitigates insiders' incentives to manage accounting earnings because they have to disclose the true operating performance of the firm. Therefore, earnings management increases with the ease with which private benefits of control can be enjoyed by the insiders and decreases with the strength of minority shareholders protection interests. These results are consistent with the prediction that investor protection plays a crucial role in mitigating earnings management in international context.

$\mathrm{Yu}$ (2005) finds that international accounting standards, accruals-based accounting standards, accounting standards with increased disclosure requirements, and separating tax and financial reporting all constrain earnings management. Francis and Wang (2008) examine the association of a country's investor protection regime with the quality of reported earnings for a large sample of firms from 42 countries. They find that abnormal accruals are smaller, there is a greater likelihood of reporting losses, and earnings conservatism is greater for firms with Big 4 auditors if a 
country's investor protection regime gives stronger protection to investors. In contrast, earnings of firms with non-Big 4 auditors are largely unaffected by different investor protection regimes. However, Fan and Wong (2005) find that high quality audits serve as an alternative governance mechanism in countries with weak investor protection. Krishnan (2003b) reports that clients of industry specialist auditors report lower discretionary current accruals and higher earnings response coefficients than clients of non-specialist auditors. They also show that the impact of industry specialist auditors in providing high quality earnings increase as the legal environment weakens. Countries with strong property laws and enforcement mechanisms facilitate informed arbitrage and capitalization of firm-specific information (Morck et al. 2000).

However, strong macro-governance in the market place should attenuate management opportunistic behaviour (Jensen and Meckling 1976; Holmstrom 1979). Alternatively poor macro governance will exacerbate opportunism. Therefore, this study argues that managers are more likely to manipulate accruals in poor macro governance environments than in strong macro governance environments.

The "law and finance theory" argues that a country's broader governance, particularly investor protection, is crucial in furthering a country's financial development. ${ }^{10}$ Moreover, financial development is now widely recognized as a major driving force of economic growth and development (Graff 2006). Recent research also suggests that high quality accounting information contributes toward financial development and ultimately economic growth. Thus the chain of causation

10 For a recent review on legal institutions and financial development, see Beck and Levine (2005). 
appears to run from legal system to public accounting information and financial development and finally to economic growth.

A number of research questions have been developed in the literature and these are discussed in the following sections.

\subsubsection{Enforcement and earnings management}

There is no straightforward and uncontroversial way to measure the strength of the legal enforcement of accounting. ${ }^{11}$ This study therefore considers a range of measures of enforcement based on six country-level factors: judicial independence, enforcement of securities laws, protection of minority shareholders' interest, enforcement of accounting and auditing standards, rule of law and press freedom. For each of these variables, a higher score denotes stronger enforcement and vice-versa.

Judicial independence measures the "efficiency and integrity of the legal environment as it affects business" (La Porta et al. 1998 and 2006; Francis and Wang 2008). A country's judicial system might be functioning well but enforcement of accounting regulations may be lacking. It is difficult, however, to think of a situation in which the judicial system in general works poorly but enforcement of accounting regulation is strong. This study uses the judicial efficiency index produced by the World Economic Forum (2008) as the measure of efficiency and integrity of the legal environment as it affects business. It runs on a scale from 1 to 7 , with lower scores indicating lower efficiency and integrity and vice-versa.

11 The difficulty in measuring enforcement arises in part because enforcement takes different forms in different countries. As Ball (2001) puts it, "The accounting infrastructure complements the overall economic, legal and political infrastructure in all countries." 
The next enforcement variable is based on a country's securities law. Enforcement of securities laws may deter insiders from manipulating earnings to benefit from trading in the firms' stock (Hope 2003a). Beneish and Vargus (2002) provide evidence that insider trading is associated with earnings management. Aboody et al. (2005) find that privately informed traders earn greater profits when trading stocks with high earnings quality risk factors. This study uses the enforcement of the securities exchange index developed by the World Economic Forum (2008) as the measure of enforcement (of securities laws). It ranges from 1 to 7 , with 1 representing the most lax enforcement regime and 7 representing the most restrictive enforcement regime.

Hung (2001), Ball et al. (2000), Leuz et al. (2003), Daske et al. (2008), La Porta et al. (1998, 2000 and 2006), and Francis and Wang (2008), conclude that countries with strong minority shareholders' interest protection are expected to enact and enforce accounting regulations that limit managerial discretionary behaviour. Therefore, weak shareholder protection environments provide managers with greater incentives as well as opportunities to engage in misleading accounting practices. Hence the third level of investor protection is minority shareholder rights. It is a measure of minority shareholders' interest protection and ranges from 1 to 7 , where 1 signifies not protected by law and 7 signifies protected by law and actively enforced.

Researchers argue that enforcement of accounting standards is as important as the accounting standards themselves (e.g. Sunder 1997; Ball 2001; Ding et al. 2007). Strong enforcement puts pressure on management and auditors are less prone to exercising their discretionary activities (FEE 2002: 29). Holthausen (2003) argues 
that adopting IAS $^{12}$ with weak investor protection will likely (lead to) ruin the perceived quality of accounting standards, and suggests that it would be useful for the literature to begin to structure and quantify the country descriptions by developing more informative tests. Yu (2005) finds that IAS, accrual-based accounting standards, accounting standards with increased disclosure requirements, and separating tax and financial reporting all constrain earnings management. She also suggests that high quality accounting standards decrease analysts' forecast error. Hope (2003) develops a comprehensive measure of accounting standards enforcement and suggests that strong investor protection encourages managers to follow the rules. Based on these arguments, this study expects a strong enforcement of accounting and auditing standards will decrease earnings management. Therefore the fourth level of investor protection is enforcement of accounting \& auditing standards. It ranges from 1 to 7 , with 1 representing the most lax enforcement of accounting and auditing standards regime and 7 representing the most restrictive enforcement of accounting and auditing standards regime.

The fifth component of enforcement, rule of law, assesses a country's law and order tradition (La Porta et al. 1998; 2000 and 2006). If no one cares, regulations covering the content of financial reports are not likely to be effective. Assessment of law and order tradition is produced by the World Bank (1999-2007). It measures the extent to which agents have confidence in and abide by the rules of society, and in particular, the quality of contract enforcement, the police, and the courts, as well as

12 IAS were the predecessors of IFRS. 
likelihood of crime and violence. It ranges from -1.39 to 2.03 , with higher scores indicating a strong rule of law and vice-versa.

Finally, press freedom enforcement assesses whether a country's citizens are able to participate in selecting their governments, as well as enjoying freedom of expression, freedom of association and a free media. Even prior to these recent collapses, free media was viewed as one of the main obstacles facing post-communist countries in attempts to introduce democratic institutions and open, market economies (Shleifer and Vishny 1997). Press freedom is also produced by the World Bank (1999-2007). It ranges from -1.66 to 1.72 , with higher scores indicating freedom of association and a free media and vice-versa.

Consistent with prior research, this study will examine the relationship between enforcement and earnings management and the relevant research question is:

\section{Does a strong system of enforcement affect earnings management?}

\subsubsection{Institutional setting and earnings management}

Earnings management is also determined by a country's overall institutional setting (Ball et al. 2000 and 2003). Leuz et al. (2003) examine the relationship between investor protection and earnings management across 31 countries using non-financial industry data. They find that a strong institutional setting at a country level reduces firms' earnings management activities and they interpret this as evidence of higher accounting quality. Bushman and Smith (2001) propose a theoretical link between high quality accounting information and economic performance and suggest that the financial accounting regime is affected by a country's broader socio-political factors 
such as legal origin, legal enforcement, and the institutional settings. Prior research also documents greater financial transparency in countries with strong institutional settings (Bhattacharya et al. 2003; Bushman and Smith 2003), and there is evidence that there is a lower earnings management in those countries (Ball et al. 2000; Hung 2001; La Porta et al. 1998, 2000 and 2006; Daske et al. 2008). North and Weingast (1989) argue that Britain has a stronger institutional setting than France. According to this view, British colonies are likely to have inherited better institutions than French colonies, and with positive implications for financial development. Thus, institutional settings may proxy for better investor protection that is not related fundamentally to the legal system. To address these issues, this study examines a proxy for the institutional setting, namely the estimate of "Regulatory Quality" in different countries compiled by The World Bank (1999-2007) for the use of foreign investors interested in doing business in the respective countries. It measures the ability of the government to formulate and implement sound policies and regulations that permit and promote private sector development. It ranges from -1.35 to 1.85 , with higher scores indicating strong institutional setting and vice-versa. The relevant research question related to the institutional settings is:

\section{Does institutional setting affect earnings management?}

\subsubsection{Political system and earnings management}

Public interest theory holds that democratic regulation is supplied in response to the demand of the public for the correction of inefficient or inequitable market practices. Democratic regulation is assumed initially to benefit society as a whole rather than 
particular vested interest. A democratic regulatory body is considered to represent the interest of the society in which it operates rather than the private interests of the regulators. According to public interest theory, regulation is the manifestation of accountability pressure on management brought by the investors, which demands that managers' rent seeking behaviour is monitored. Accountability is assumed initially to benefit investors as a whole rather than particular vested interest groups. Management is considered to represent the interest of the investors in which it operates rather than the private interests of the managers. In contrast, McChesney (2001) claims that rent extraction by managers causes considerable manipulation of accounting numbers in order to extract private benefits.

In general, political stability may value high quality accounting because accounting is needed for a robust financial system. Therefore, it might be that political stability and democracy affect both accounting and irregularities. Political instability has been credited with eroding trust in the political system and reducing interpersonal trust in society (Seligson 2002). Shleifer and Vishny (1993) indicate that, "the first step to reduce accounting irregularities should be to create an accounting system that prevents theft from the government". Further, Tanzi and Davoodi (1997) explain that less political stability encourages irregularities in government budgeting and is highly likely when "some of the essential controlling or auditing institutions are not well developed". Likewise, Leiken (1997) indicates that the US can help control accounting irregularities in multilateral development banks by demanding that these banks "enforce their own rules on effective accounting systems, adequate internal controls, and timely audits". A detailed study of institutional determinants of reporting conservatism internationally by Bushman and 
Piotroski (2006) finds support for this political economy hypothesis, which connects the role of government to the properties of accounting information. Managers will opt for income decreasing earnings management if politicians are likely to expropriate resources from their firms if perceived to be successful. On the other hand, managers could opt for income increasing earnings management if they expect that government is aiming to penalise inefficient organizations.

Countries with unstable and unwieldy governments are more prone to be corrupt (DiRienzo et al. 20007; Alam 1995; Rose-Ackerman 1978; and Tanzi 1998). Ades and Di Tella (1999) and Terisman (2000) claim that more open economies are less likely to experience financial irregularities. Further, it is often the politicians that create laws and organizations that govern accounting standards and enforcement. Since rent-seeking public officials have the incentive to allow financial irregularities, they may create a situation in which poor accounting and auditing occurs. As a proxy for the political system, this study uses the estimate of "Political Stability and Absence of Violence" in different countries compiled by the World Bank (19992007) for the use of capturing perceptions of the likelihood that the government will be destabilized or overthrown by unconstitutional or violent means, including political-motivated violence and terrorism. It ranges from -1.99 to 1.51 , with higher scores indicating stable political regime and vice-versa. The research question regarding the political system is:

\section{Does the political system affect earnings management?}




\subsubsection{Corruption and earnings management}

Corruption has been defined as the misuse of entrusted power for private gain (Transparency International 2008). By definition it requires illegal practices and often has to do with illegal cash payments, misallocation of assets, and other inappropriate transactions (Husted 1999; Terisman 2000). Corruption is a serious global problem that affects many countries throughout the world (Transparency International 2008; United Nations 2008; World Health Organization 2008). The World Bank (2001) has indicated that corruption is "the single greatest obstacle to economic and social development." Research has suggested that corruption reduces foreign direct investment and hence economic growth (Mauro 1995; Wei 1997), lowers investment in education and health (Mauro 1997), and places less corrupt countries at a disadvantage when seeking international contracts (Kantor 1996).

Corruption distorts public investment and decreases public expenditures for operation and maintenance of investments (Tanzi and Davoodi 1997). Furthermore, corruption reduces revenues generated through taxation, contributing to the inability of some governments to function properly (Tanzi and Davoodi 1997). Corruption has been credited with eroding trust in the political system and reducing interpersonal trust in society (Seligson 2002). Accounting seeks to make all economic transactions of an organization transparent. In other words, accounting helps to ensure that private companies demonstrate that they operate legally, and that public institutions are accountable to the public. As a result, there should be an inverse relationship between a country's accounting quality and its perceived level of corruption. To capture this phenomenon, this study examines as a proxy for corruption, estimates of "Control of Corruption" in different countries compiled by the World Bank (1999-2007), 
capturing perceptions of the extent to which public power is exercised for private gain, including both petty and grand forms of corruption, as well as "capture" of the state by elites and private interests. It ranges from -1.29 to 2.57 , with higher scores indicating least corrupt regime and vice-versa. The research question regarding perceived corruption is:

\section{Does perceived corruption affect earnings management?}

\subsubsection{Culture and earnings management}

Business research suggests that national cultural values influence managerial decision making (Hofstede 1980; Gray 1988; Salter and Niswander 1995; Stulz and Williamson 2003; Hope 2003; House et al. 2004; Guisao et al. 2006). Accounting research has also taken a strong interest in the role that culture plays in financial and managerial accounting settings. In particular, accounting researchers have employed “Gray’s (1988)” framework for linking commonly identified national culture values (based on Hofstede 1981) to accounting. Jaggi and Low (2000) examine the relation between culture, legal systems, and accounting disclosures. They find that culture has little or no effect on disclosure levels once the legal system taken into account. In contrast, using a larger sample than Jaggi and Low (2000), Hope (2003) documents that culture values have explanatory power for firms' disclosure even after controlling for variation in legal origin.

To understand the association between culture and earnings management, prior research has focused primarily on the association between culture and firm disclosure (Jaggi and Low 2000; Hope 2003). This study examines the relation 
between culture and earnings management directly and uses as a proxy for culture the culture value index developed by the World Economic Forum (2008) as the measure of ethical behaviour in interactions with public officials, politicians, and other enterprises in countries. It ranges from 1 to 7 , with 1 representing the world's worst level of corporate ethics of firms and 7 representing the best level of corporate ethics of firms. The research question is:

\section{Does national culture affect earnings management?}

\subsubsection{Adoption of IFRS and earnings management}

Schipper (2005) argues that the adoption of IFRS in the European Union (EU) provides a more powerful setting to test the determinants and economic consequences of accounting quality because accounting standards across EU countries are now the same. Barth et al. (2006) suggests that firms that adopt IFRS are less prone to engage in earnings smoothing and are more likely to recognize losses in a timely manner. Similar findings are reported by Jennings et al. (2004) and Armstrong et al. (2010). According to Soderstrom and Sun (2007), adoption of a common set of accounting standards such as IFRS improves earnings quality because management is under pressure to report a true and fair view and engage in less earnings management activities. Reflecting this line of thought, Ewert and Wagenhofer (2005) find that high quality accounting standards reduce earnings management and improve reporting quality.

Ball (2001) argues that IFRSs will provide high quality accounting information in a public financial reporting and disclosure system characterized by (i) 
training of the audit profession in adequate numbers, high professional ability, (ii) independence from managers to certify reliably the quality of financial statements; (iii) separation as far as possible, of the systems of public financial reporting and corporate income taxation, so that tax objectives do not distort financial information, (iv) reform of the structure of corporate ownership and governance to achieve an open-market process for reliable public information, (v) establishment of a system for setting and maintaining high-quality, independent accounting standards, and (vi) perhaps most important of all, establishment of an effective independent legal system for detecting and penalizing fraud, manipulation, and failure to comply with standards accounting and other required disclosure, including provision for private litigation by stockholders and lenders who are adversely affected by deficient financial reporting and disclosures. Biddle and Hillary (2006) find that high quality accounting information reduces the investment-cash flow sensitivity in market based economics (strong investor protection) but not in bank-based, creditor dominated economies.

Contrary to the above studies, van Tendeloo and Vanstraelen (2005), and Lin and Paananen (2007) examine the discretionary accruals of German firms adopting IFRS and find that IFRS firms have more discretionary accruals and that there is a low correlation between accruals and cash flows. Similarly Paananen, (2008) investigates whether the quality of financial reporting in Sweden increased after the adoption of IFRS and finds that the quality of financial reporting (measured by the degree of smoothing of earnings) decreased after the adoption of IFRS. Platikanova and Nobes (2006) compare the information asymmetry component of the bid-ask spread among companies before and after the EU's adoption of IFRS in 2005. They 
find a larger volatility in the information asymmetry component for UK and German companies. They also find that companies from countries where earnings management is more common exhibit a lower information asymmetry component compared to other groups of countries. They interpret this result as indicating that income smoothing reduces information asymmetry.

This study uses as the proxy for IFRS adoption a dummy variable that takes the value of 1 for a given country in years after mandatory IFRS adoption and 0 , otherwise. The relevant research question is:

\section{Does adoption of IFRS affect earnings management?}

\subsection{Micro governance and earnings management}

There has been considerable research examining the impact of various measures of governance on the likelihood of observing earnings management (Farber 2005). For example, with board and audit committee characteristics (Dechow et al. 1996; Beasley 1996), measures of board characteristics, block holders and CEO duality (Peng and Roell 2006; Erickson et al. 2006), and measures of executive compensation (Share and Share 1999).

Consistent with prior research, a number of research questions have been developed in the literature and these are discussed in the following sections:

\subsubsection{Initial public offerings and earnings management}

Capital market transactions, such as an IPO or SEO could provide an incentive for earnings management. If management assumes that investors decide on whether to 
subscribe for an issue on the basis of past earnings, managers could attempt to manage earnings upward through accruals manipulation. According to catering theory, managers cater to investors by inflating earnings in periods when investors react optimistically to positive earnings surprises (during IPO, SEO) relative to negative earnings surprises and report more conservatively when investors react pessimistically to earnings news. This study considers earnings management during IPOs and uses as a proxy the IPO index developed by the World Economic Forum (2008), viz, the measure of total IPO proceeds as a percentage of GDP. The relevant research question is as follows:

\section{Do managers manage earnings during initial public offerings?}

\subsubsection{Debt contracts and earnings management}

A debt contract can be regarded as a governance mechanism, on the basis that debtholders monitor and evaluate managerial performance. Although the level of debt is an internal decision, higher debt is expected to be associated with higher monitoring from debt holders (Agrawal and Knoeber 1996; Daniels 1995). While the literature suggests firms with high debt are more likely to be associated with earnings management to avoid debt covenant violations (DeFond and Jiambalvo 1994; Sweeney 1994), a counter response from the finance literature recognises that debt could have a positive monitoring effect (Keasey and Wright 1997; Rubin 1990; Jensen 1986; OECD 1999; Maher and Andersson 2000). An important part of the financing process is risk assessment by debt holders. Hence, debt holders have an 
incentive to monitor managerial performance to assess the risk of the firm (Barua et al. 1999).

Debt holders have the potential to increase the level of external monitoring because of their industrial knowledge and continuous transactions. Debt holders are able to develop a broadly based benchmark to evaluate firm performance when they provide loans to a number of different firms in the same industry (Daniels 1995). The renewal of short term or medium term loan agreements gives debt holders the opportunity to act on the result of monitoring managerial performance (Daniels 1995). Debt holders are able to make demands on a firms' management within the debt contract and have the capacity to pressure managers to act in the interests of debt holder (Dedman 2000).

Monitoring by debt-holders will depend on the size of the stake the debtholder in the business (Daniels 1995). The higher the debt reliance (leverage), the closer the firm is likely to be to constraints in the debt contract (Kalay 1982). Unless firms are reasonably close to violation, it is unlikely that the choice of an accounting method will be constrained by debt restrictions (DeFond and Jiambalvo 1994). Hence, high leverage justifies a strong monitoring role by debt-holders (OECD 1995).

It can be argued that managers have the incentive to provide more relevant and reliable information to debt-holders and comply with debt covenants in order to obtain finance on more favourable terms and/or gain renewal of financing. Harris and Raviv (1991) find that the evidence is broadly consistent with the view that debt can mitigate agency conflicts. Grossman and Hart (1982) assert that debt forces managers to conduct operations more efficiently in order to lessen the probability of bankruptcy, loss of control and loss of reputation. This study uses, as the proxy for 
debt covenant violation, the long-term debt to equity ratio, labelled as LEV. This is obviously an indirect approach, but provided DACCR is measured with minimum of noise and the debt level represents the actual outstanding obligations of the borrower, a relationship is expected between the two (Ashton et al. 2004 and Ataullah et al. 2007). We expect a positive association between accounting discretion and leverage. This leads to the following research question:

\section{Do managers manage earnings to avoid violating debt covenants?}

\subsubsection{Performance based compensation contracts and earnings management}

Explicit and implicit management compensation contracts are often used to align the interests of management and external stakeholders. These contracts create incentives for earnings management and it is likely that creditors and compensation committees may find it costly to undo the effects of earnings management. Evidence supporting this management compensation theory can be found in Dechow and Sloan (1991) who find that managers decrease research and development expenditure in the final year of their term in order to increase earnings and thus their payout, upon leaving the company. A number of studies have examined actual compensation contracts to identify managers` earnings management incentives. On balance, the evidence reported in these studies is consistent with managers' using accounting judgment to increase earnings-based bonus awards (Healy 1985; Holthausen et al. 1995). Watts and Zimmerman (1986) found that executives manage earnings to meet the bonus targets. Earnings were managed upwards to avoid falling short of earnings-based 
bonus targets (Larcker 2003; Larcker and Richardson 2004; and Peng and Roell 2006).

Clearly, firms may engage in earnings management to manage earnings either up or down, depending on the management incentives that may be present. This conclusion is supported in the theoretical model recently developed by Koch and Wall (2000). In their model, executives maximize their compensation by using accruals to manage earnings. This study examines the relation between bonus and earnings management directly and uses, as a proxy for bonus, the extent of incentivebased compensation index developed by the World Economic Forum (2008). An aggregate measure of management compensation package ranging from 1 to 7 , with 1 signifying compensation exclusively on salary and 7 signifying in larger part of income is derived from performance-based benefits (bonus, stock options, etc.). This leads to the following research question:

\section{Do managers manage earnings to increase performance based compensation?}

\subsubsection{Audit quality and earnings management}

Ball et al. (2003) study the influence of the incentives of managers and auditors on the properties of reported accounting numbers under high quality accounting standards. They find that earnings reported in four East Asian countries exhibit properties similar to code law accounting, even though these countries have common law standard setting and their recent standards closely resemble International Accounting Standards (IAS). They conclude that auditor and manager incentives

influence choice among accounting standards, and thus the quality of reported 
earnings. Similarly, Francis and Wang (2008) find that earnings quality is higher as the country's investor protection regime becomes stronger, but only for firms with Big 4 auditors. External stakeholders expect the Big 4 auditors to limit earnings management and, more generally, ensure fair financial reporting. Thus, stakeholders are more likely to sue the auditor if they perceive a failure in financial reporting (Palmorse 1987 and 1988; Stice 1991; Francis et al. 1994; Lys and Watts 1994). The Public Company Accounting Oversight Board (PCAOB) explains:

The media, litigants, the congress, and others often allege, rightly or wrongly, that audit failures contributed to many business failures. In that context, the public views audit failure as including not only the failure to discover and report material negative facts, but also the failure of financial statements to serve as an adequately early-warning device for the protection of investors and creditors.

DeAngelo (1981) explains that Big 4 auditors in the US push for a high level of earnings quality in order to protect their brand name reputation from legal exposure and reputation risk which can arise from misleading financial reports by clients and, in particular, from overly optimistic earnings reports. In the same line of study, Krishnan (2003b) finds that Big 4 auditors mitigate accruals-based earnings management more than non Big 4 auditors and therefore influence the quality of earnings. Similar results may hold for other countries with strong investor protection. This study investigates Big 4 versus non-Big 4 auditors by including a dummy coded 1 for firms audited by Big 4 auditors and 0 otherwise. The relevant research question is:

\section{Do quality auditors affect earnings management?}




\subsubsection{Board size and earnings management}

Board size is another important firm characteristic that may have an effect on earnings management. The board of a company provides leadership and strategic guidance, objective judgement independent of management to the company and exercises control over the company, while remaining accountable to the shareholders. The board directs the company, by formulating and reviewing company policies, strategies, major plans of action, risk policy, annual budgets and business plans, setting performance objectives, monitoring implementation and corporate performance, and overseeing major capital expenditure, acquisitions and divestitures, changes in financial control and compliance with applicable laws, taking into account the interests of stakeholders. It controls the company and its management by laying down a code of conduct, overseeing the process of disclosure and communications, ensuring that appropriate systems for financial control and reporting and monitoring risk are in place, evaluating the performance of management, chief executive, executive directors and providing checks and balances to reduce potential conflicts between the specific interests of management and the wider interest of the company and shareholders, including misuse of corporate assets and abuse in related party transactions. The board is accountable to the shareholders for creating, protecting and enhancing wealth and resources for the company and reporting to them on performance in a timely and transparent manner. Goodstein et al. (1994) argue that smaller boards, between four to six members might be more effective since they are able to make more timely strategic decisions, while larger boards may have greater capability for monitoring the actions of top management (Zahra and Pearce 1989).

Large boards with members with a wide range of expertise could increase the 
synergetic monitoring of the board in reducing the incidence of earnings management. Rahman and Ali (2006), Peasnell et al. (2005), and Xie et al. (2003) found that having a larger board is associated with less earnings management. The relevant research question is as follows:

\section{Does board size affect earnings management?}

\subsubsection{Board effectiveness and earnings management}

Board effectiveness ${ }^{13}$ also plays an important role as independent scrutinisers of managements' actions and custodians of shareholder wealth. The concept of 'independence' in independent directors was defined as "[I]ndependent directors are directors who, apart from receiving directors' remuneration, do not have any other material pecuniary relationship or transaction with the company, its promoters, its management or its subsidiaries, which in the judgement of the board, may affect their independence of judgement" (OECD 1999). All pecuniary relationships or transactions of the non-executive directors should be disclosed in the annual report. The literature on governance emphasises the role played by an independent board in ameliorating agency problems between the divergent interests of shareholders and management of the company through monitoring managerial behaviour (Peasnell et al. 2005). Moreover, Fama (1980) argues that independent directors have an incentive to protect shareholder wealth in order to protect the value of their reputation capital. Peasnell et al. (2006) and Ebrahim (2007) find that companies with a higher proportion of independent directors on the board tend to have lower abnormal accruals. Liu and Lu (2002) find that earnings management by managers in China is

13 Board independence and board effectiveness are used often interchangeably in the literature. 
constrained to a certain extent when the firms are dominated by outside directors and when firms have shares traded by foreign investors. This study uses the board effectiveness index developed by the World Economic Forum (2008) as a proxy for board effectiveness. It is a measure of corporate governance by investors and boards of directors in a country and ranges from 1 to 7 , with 1 signifying management has little accountability and 7 signifying investors and boards exert strong supervision of management decisions. The relevant research question is:

\section{Does board effectiveness affect earnings management?}

\subsubsection{Ownership concentration and earnings management}

Separating the risk bearing function of ownership and the managerial function of control in the modern corporation causes the classic principal-agent problem between owners and managers for non-value maximizing behaviour by managers (Jensen and Meckling 1976). In a dispersed ownership scenario, with manager owing a significant share of the company, managers have a strong incentive to engage in earnings management and the existence of information asymmetry makes it difficult for outsiders to undo the effects of earnings management.

Recent research provides evidence that many US corporations have significant equity ownership by insiders (CEO, officers, and executive members of the board of directors) and/or shareholders that own a significant block of equity (Holderness and Sheehan 1998).

In a concentrated ownership environment, agency problems arise between controlling shareholders and minority shareholders. La Porta et al. (1999) find a high 
degree of ownership concentration in firms from countries with relatively poor country-level governance and argue that the conflict between large shareholders/sponsor owners and minority shareholders is the primary firm-level governance problem in such countries. In companies with concentrated ownership, controlling shareholders can expropriate wealth from minority shareholders in many ways. For example, they can extract cash by selling assets, goods or services to the company through self-dealing transactions, they can obtain loans on preferential terms, they can transfer assets from the listed company to other companies or entities under their control, or they can dilute the interest of minority shareholders by acquiring shares at a preferential price (Johnson et al. 2000).

Although these activities are not within the narrow purview of earnings management, the argument here makes it clear that even in countries with concentrated ownership; sponsor/owners families have incentives to engage in earnings management activities to portray their corporate performance in the best possible light to minority shareholders. This study uses the average percentage of common shares owned by the three largest shareholders in the ten largest firms in a given country from La Porta et al. (1998 and 2006) to measure the overall extent of ownership concentration ( $\mathrm{OWN}$ ) as the proxy for the level of agency costs in that country. High values stand for higher ownership concentration. The relevant research question is:

Does higher concentration of ownership affect earnings management? 


\subsection{Summary}

This chapter has set out the research questions for testing this study. The research questions relate to the relationship between both macro and micro governance factors and earnings management and reflect the review of the literature set out in this chapter and earlier chapters. 


\begin{tabular}{|c|}
\hline Chapter Four \\
Research Design \\
\hline
\end{tabular}

4.1 Introduction

4.2 Overview of research design

4.2.1 Macro governance and earnings management

4.2.2 Micro governance and earnings management

4.2.3 Joint effect of micro and macro governance on earnings management

4.3 Control variables

4.4 Sample selection and data collection procedure

4.4.1 Study period

4.4.2 Sample selection

4.5 Operationalisation of the constructs

4.5.1 Macro governance

5.5.2 Micro governance

4.5.3 Earnings management

4.5.3.1 Aggregate accruals model

4.5.3.1 (i) Jones (1991) model

4.5.3.1 (ii) Modified Jones (Dechow et al. 1995) model

4.5.3.2 Cross-sectional Models 


\subsubsection{2 (i) Cross-sectional Jones model}

4.5.3.2 (ii) Cross-sectional modified Jones model

4.5.3.3 Measuring total accruals

4.6 Analytical procedures

4.6.1 Step one: Data collection and descriptive statistics

4.6.2 Step two: Computing discretionary accruals

4.6.3 Step three: Regression analysis

4.6.4 Step four: Robustness checks

4.7 Research questions

4.8 Summary 


\subsection{Introduction}

Chapter One identified earnings management as the broad area of this research. Chapter Two developed the link between governance (both micro and macro level) and earnings management, Chapter Three set out the questions to be empirically tested in this study, and this chapter describes the research design. The Chapter proceeds as follows: Section 4.2 gives an overview of the research design, Section 4.3 discusses the control variables, Section 4.4 describes the sample selection and data collection procedures, Section 4.5 describes the operationalisation of the constructs in the model and Sections 4.6 describes the analytical procedures undertaken. Section 4.7 provides the summary of the research questions and, finally Section 4.8 summarises the chapter.

\subsection{Overview of research design}

Signed discretionary accruals, estimated using the modified Jones Model (Dechow et al. 1995) was used as the measure of earnings management. Signed discretionary accruals are used rather than unsigned discretionary accruals for two reasons. First, we are interested primary in the use of managerial discretion to increase reported earnings as this is the misreporting scenario most likely to impair accounting objectives. Finally, Hribar and Nichols (2006) report empirical evidence that signed discretionary accruals are a better measure of earnings quality than the unsigned value of discretionary accruals. Importantly, note that this model is not a random walk expectation model in which total accruals are simply expected to be the same dollar amount as last year's accruals. Rather, accruals are assumed to have a constant liner relationship over time with sales and gross PPE that can be used to predict 
current period accruals for a given level of sales and gross PPE ${ }^{14}$. The accounting and corporate disclosure data for the study was collected from the OSIRIS (http://www.osiris.com/home) database (2009); World Economic Forum (http://www.weforum.org/home) database (2008) and The World Bank (http://www.worldbank.org/home) database (1999-2007) and covers the period $1998 / 99$ to $2006 / 2007$. Financial and mining companies were excluded from the sample because of their special economic structure and regulated entities because of the nature of their operating environment.

Researchers have primarily relied on the legal protection database compiled by La Porta et al. (1997 and 1998) for their investor protection measures. Spamann (2006), however, raises concern over the construction of one of the most routinely used investor protection measures 'Antidirector Right Index' (ADRI). Following a consistent coding process, Spamann (2006) does not find any significant differences between common law and code law countries with respect to ADRI values. Moreover, Kaufmann et al. (2007) report that there were substantial changes in governance structure over the period 1996-2006. For this reason this study uses the recent World Economic Forum data (2008) and the World Bank data (1999-2007).

The general structure of the models tested is shown below and illustrated in diagram 5-1 and was tested using both pooled and year wise OLS regression.

Dependent variable $_{i, t}=\alpha+\Sigma \beta$ Governance Factors $_{i, t}+\Sigma \beta$ Controls $_{i, t}$

${ }^{14}$ Francis and Wang (2008) also adopt the same techniques to study in a cross-country comparison. 
Diagram $4-1$ below depicts the conceptual model underlying the thesis.

Diagram 5-1: Conceptual Model

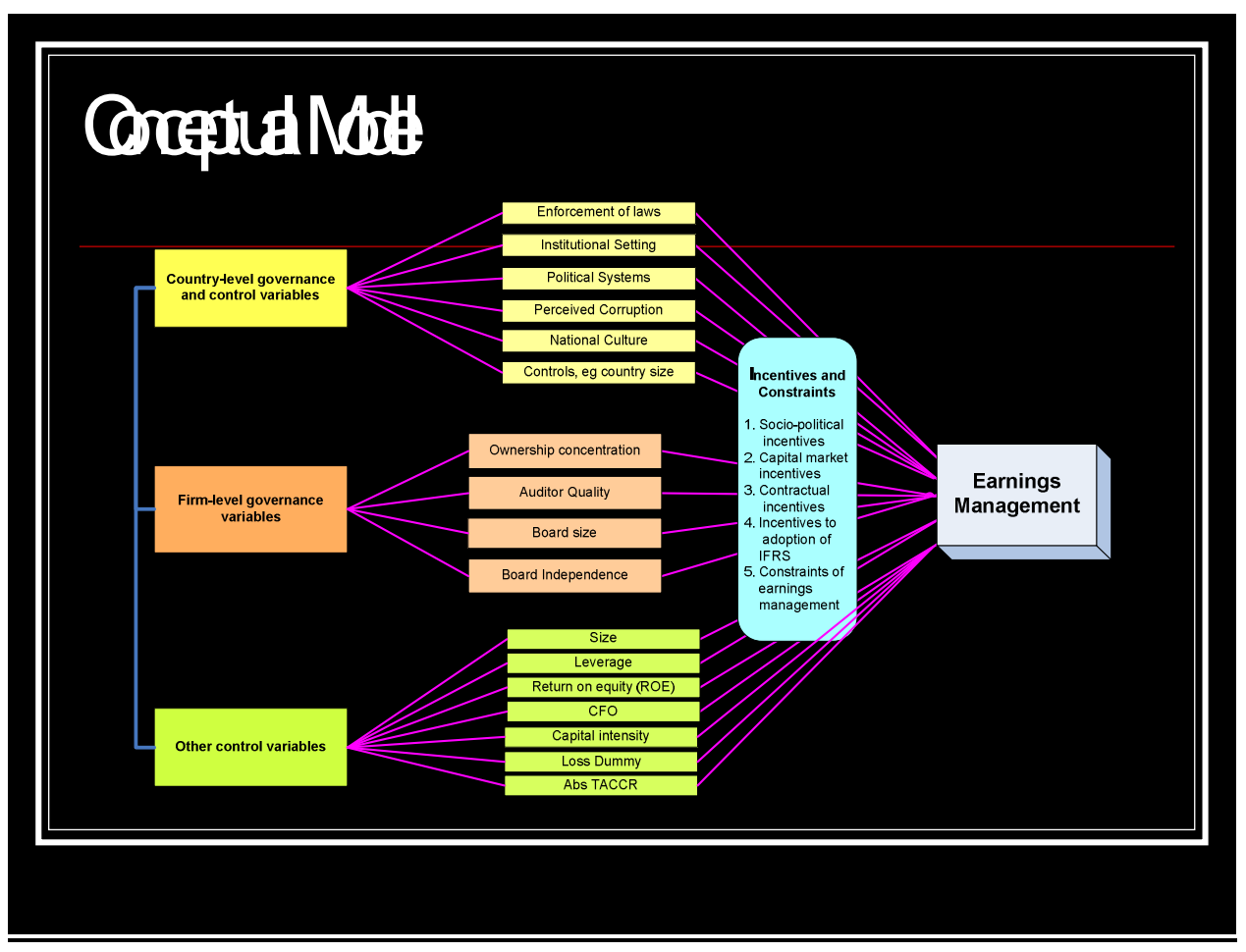

The following sections present the proposed models and state the specific research questions based on the discussions in Chapters Three and Four.

\subsubsection{Macro governance and earnings management}

The following model is used to examine the impact of macro governance on earnings management.

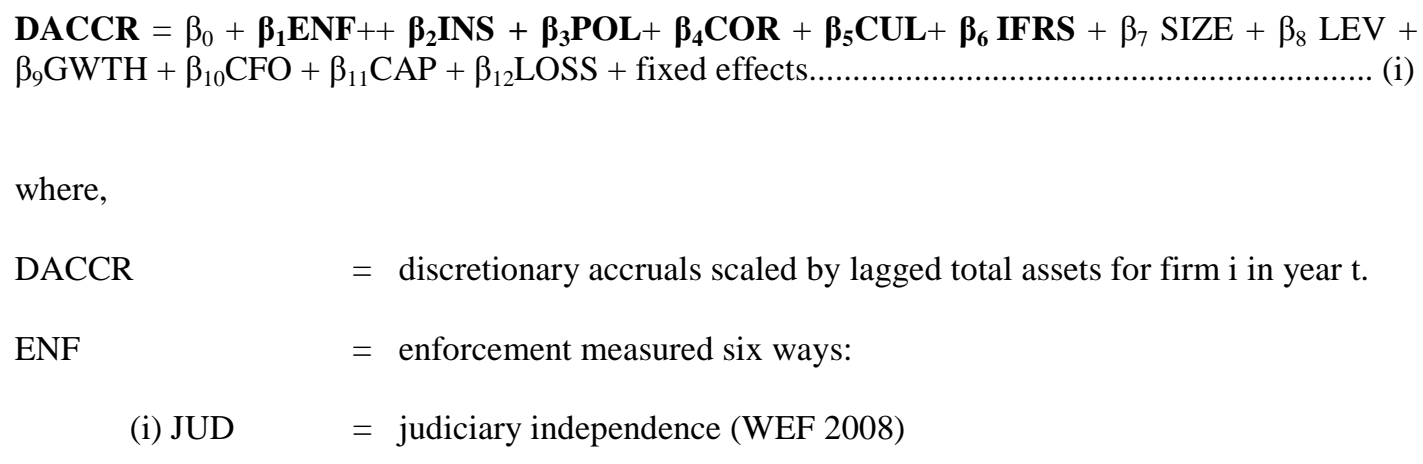




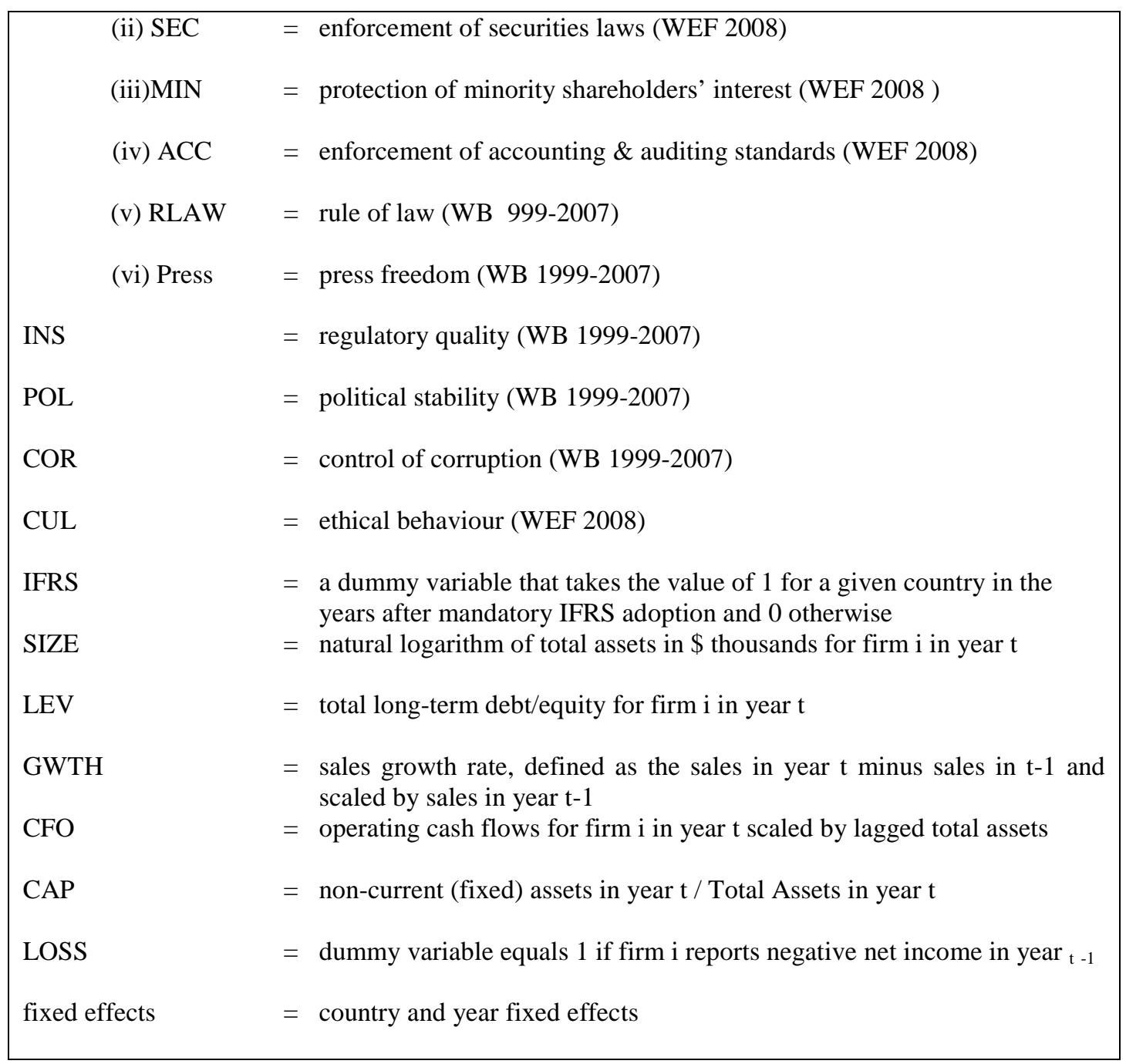

Francis and Wang (2008), Daske et al. (2008), Hope et al. (2008) and Leuz et al. (2003) found a significant association between country-level governance and earnings management. Similar results are anticipated in this study. All country-level governance variables are expected to display a negative association with the magnitude of discretionary accruals ${ }^{15}$.

15 As country-level governance is represented by ten variables, there are five sub-hypotheses and the primary hypothesis is expressed in general terms as the directionality of the coefficient depends on the nature of each country-level governance variable. 


\subsubsection{Micro governance and earnings management}

The following model is used to examine the impact of micro governance on earnings management.

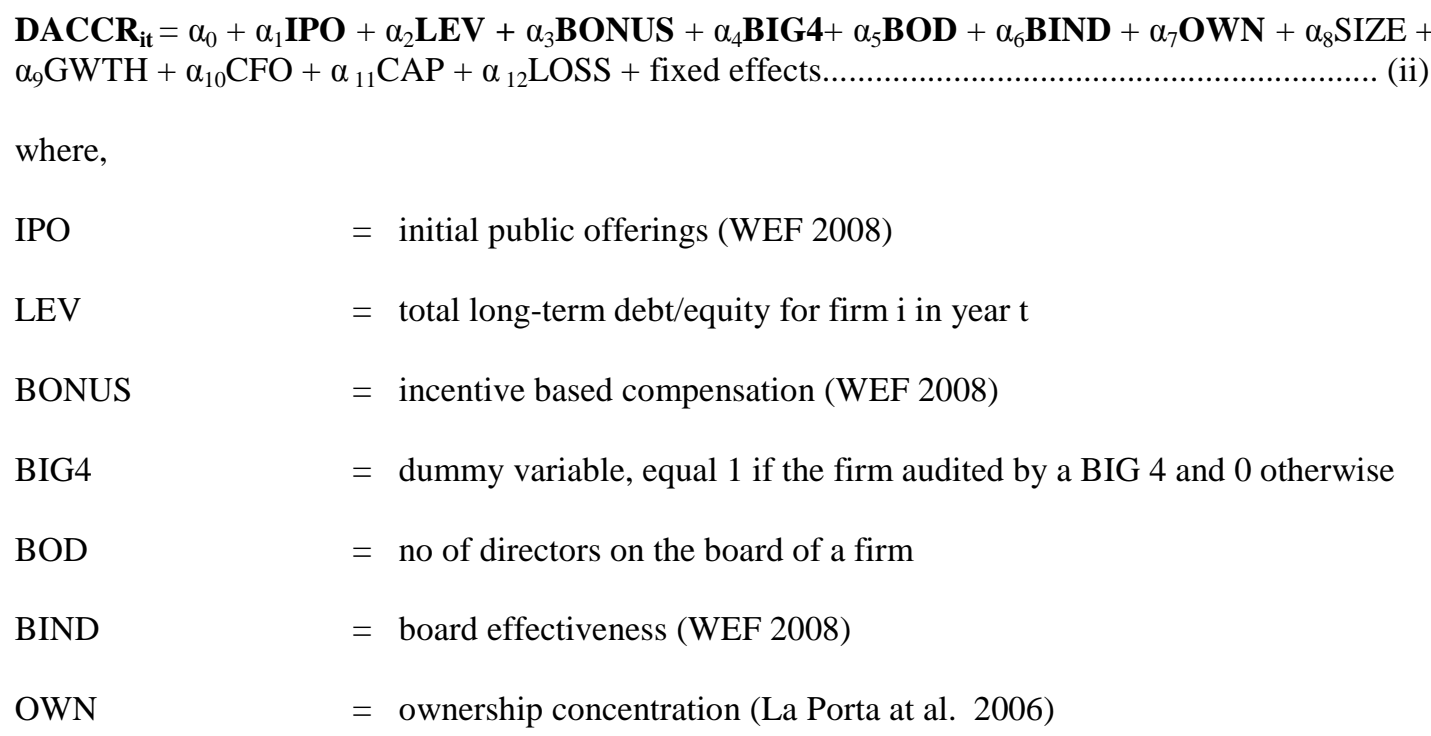

The other variables are defined as in equation (1), and the coefficients $\alpha_{1}$ to $\alpha_{7}$ are the basis for tests of the effects of micro-level governance on earnings management.

\subsubsection{Joint effect of micro and macro governance on earnings management}

Ball et al. (2003) argue that adopting high quality standards might be a necessary condition for achieving high quality information, but not a sufficient one. This study therefore examines earnings quality as a joint function of macro governance and micro governance variables by using exploratory principal component analysis (PCA) of 10 macro governance variables, viz, judicial independence, enforcement of securities laws, protection of minority shareholders' interest, enforcement of 
accounting \& auditing standards, rule of law, press freedom, regulatory quality, political stability, control of corruption, and ethical behaviour.

The following model is used to examine this issue:

DACCR $_{\text {it }}=\gamma_{0}+\gamma_{1}$ MACRO $+\gamma_{2}$ MICRO $+\gamma_{3}$ MACRO $*$ MICRO $+\gamma_{4}$ SIZE $+\gamma_{5}$ LEV $++\gamma_{6} \mathrm{GWTH}$ $+\gamma_{7} \mathrm{CFO}+\gamma_{8} \mathrm{CAP}+\gamma_{9} \mathrm{LOSS}+$ fixed effects.

All of the variables are defined as in equations (1) and (2), and the coefficients $\left(\gamma_{1}, \gamma_{2}\right.$, and $\left.\gamma_{3}\right)$ test the joint effect of micro and macro governance on earnings management. Equations (i) to (iii) are estimated using the procedure in Rogers (1993) to derive t-statistics and p-values that are robust in respect of hetroscedasticity. In addition, since macro governance variables take on the same value for every firm within a country, it is possible that country effects are overstated due to repeated observations within countries. The Rogers (1993) procedure also controls for the country clustering effects and the common variance among observations within a particular country. Equation (1 to 3 ) is estimated as a fixed effects model with year-specific dummy variables to control for systematic time period effects and country dummies to provide additional controls for omitted variables that could affect firm-level accruals. For succinctness, the year and country dummies are not reported in the tables.

\subsection{Control variables}

The above models include control variables which have been identified in the prior literature as being relevant to explanation of variation in discretionary accruals. The individual variables are discussed below. 


\subsubsection{Size}

Two opposing views exist on the role of firm size in earnings management. Kim et al. (2003) note that the larger the firm's size, less that earnings management may be feasible. First, the size of firms is related to its internal control system. Larger sized firms may have more sophisticated internal control systems and have more competent internal auditors as compared to small sized firms. An effective control system contributes to the reliability of financial information disclosed to the public (Watts and Zimmerman 1978). Second, larger firms are usually audited by auditors from the big6/5/4 accounting firms who could prevent earnings misrepresentation. Third, large firms take into account the reputation costs when engaging in earnings management. Finally, large firms may be less likely to manage earnings relative to smaller counterpart firms because they are followed by more financial analysts.

In contrast, an opposing view suggests that larger sized firms are more likely to manage earnings than small-sized firms. First, large-sized firms face more pressure to meet analysts' expectations. Second, large sized firms have greater bargaining power with auditors. Nelson et al. (2002) document that auditors are more likely to waive earnings management attempts by large clients. Third, large sized firms have more room to manoeuvre given the wider range of accounting treatments available. Finally, large- sized firms may manage earnings to decrease political costs (Watts and Zimmerman, 1978; Hagerman and Zmijewski 1979; Bowen et al 1981; Dhaliwal 1988). Bathke et al (1989) document a positive relationship between firm size and earnings quality. This study uses the natural logarithm of total assets to proxy for firm size (SIZE) and, on balance, the association between discretionary accruals and firm size is expected to be positive. 


\subsubsection{Leverage}

As discussed in section 3.3.2 on debt contracting, LEV is included as a proxy for debt covenant violation. LEV is measured as the ratio of total long term-debt to equity, where total long term debt in the OSIRIS database represents all interest bearing obligations due after the current operating cycle. ${ }^{16}$ The sign of the coefficient on LEV is expected to be positive, that is, earnings management increases with leverage. Note that while LEV is a control variable in equations (i) and (iii) it is one of the micro governance variable in equation (ii).

\subsubsection{Growth}

To avoid adverse affects on the cost of capital, managers have an incentive to smooth earnings as earnings volatility increases with high growth and the market tends to punish growth firms for negative earnings surprises (Sloan 2001; Beaver 1968). Therefore, high growth firms are likely to have strong incentives to meet earnings targets. Krishnan (2003a) documents a significant positive relationship between firms' growth level and earnings management. Young (2000) finds that discretionary accruals are positively associated with firm growth since firms experiencing large growth will incur high investment in working capital. Moreover, firms with more growth potential are expected to make more accruals and hence discretionary accruals choices (Firth et al. 2007; Rath and Sun 2007). This study uses the return on equity (ROE) as a proxy for growth opportunities and the association is expected to be positive.

16 Bank debt is not available in the OSIRIS database 


\subsubsection{Cash flow from operations}

To control for firm performance, cash flow from operations (CFO) is included as a control variable. This study includes cash flow from operations (CFO) deflated by lagged total assets, and the coefficient on $\mathrm{CFO}$ in expected to be negative because there is a well documented inverse relation between CFO and accruals (Francis and Wang 2008).

\subsubsection{Capital intensity}

Managers' discretionary accruals choices depend on the mix of current versus noncurrent assets and liabilities. Capital intensity measures a firms' efficiency in deployment of its non current (fixed) assets to its total assets. Burgstahler and Dichev (1997) suggest that firms with a larger current ratio provide more opportunity for the managers to manage earnings through working capital accruals than firms with large non-current assets/liabilities. Ruth and Sun (2007) and Young (1999) report a negative relationship between capital intensity and discretionary accruals. On the other hand, Francis and Wang (2008) report a positive insignificant relationship between capital intensity and discretionary accruals choices. Thus, no prediction is made regarding the sign of CAP. This study includes capital intensity as the ratio of non-current assets to the total assets (CAP).

\subsubsection{Loss dummy}

Lower reported earnings also provide the motivation for firms to manipulate earnings because these firms possibly facing more financial difficulties. Prior research suggests that earnings management firms tend to exhibit high profitability given the 
link to managers' job security and accounting profit based compensation contracts. (Fudenberg and Tirole 1995; Rath and Sun 2007). Wang (2004) provides convincing evidence that the firms' propensity to manipulate earnings is positively related to growth prospects and negatively to the profitability of the firms' current assets. The basis for his anticipation is that firms with strong growth opportunities but low profitability (or low cash flow) should have greater demand for more profit. Earnings management is also a forward-looking exercise. Managers are more likely to consider future earnings when they make accounting policy choices. If current earnings are low but managers expect that future earnings will be high, they may engage in income-increasing earnings management (borrowing future earnings). On the other hand, if current earnings are high but managers expect that future earnings will be low, they may engage in income-decreasing earnings management (saving today's income for tomorrow's use). A dummy variable is used for firms with losses (LOSS) as a proxy for financial distress and bankruptcy risk and therefore an incentive to increase reported earnings in the subsequent year.

\subsection{Sample selection and data collection procedure}

\subsubsection{Study period}

The study focuses on a 9-year period beginning in the 1998-1999 financial year and ending in the 2006-2007 financial year because of the following reasons:

(i) The last decade was highly eventful in the history of accounting. It saw some of the biggest accounting scandals in history led by Enron in 2001 and followed by many high profile accounting failures around the world. 
(ii) Enron's accounting failings not only led to the biggest bankruptcy in US corporate history, it led to the demise of the fifth largest professional accounting firm and one of the oldest brands in the professional accounting services industry. The regulatory response to the events surrounding Enron and Andersen was equally spectacular. Sarbanes Oxley Act, passed in July 2002 by the US Congress, brought about radical changes affecting accounting, auditing and corporate governance, not seen since the formation of US SEC in 1934. Many other developed economies in Europe, the Far East and Australia carried out similar reforms of their auditing and corporate governance regulations. Due to the sweeping changes in auditing and corporate governance introduced by SOX, earnings management in the US and countries' implementing SOX-like provisions is likely to have decreased. However, it is also possible that earnings management has actually increased post-SOX as managers have incentives to smooth the impact of SOX on financial performance.

(iii) The reorganisation of the IASC as IASB in 2001 and the subsequent revitalization of its activities have led to the rise of IASB as the global accounting standard setter with IFRS adopted or permitted in more than 100 countries around the world. With the adoption of IFRS, international differences in accounting are likely to decrease and therefore it is also a useful setting to examine the effects of macro governance on earnings quality. There has been a common expectation that adoption of IFRS would result in higher earnings quality. However, growing evidence indicates that actually it may not be resulting in increased quality. In any case, the impact appears to be crucially dependent on the macro setting.

(iv) The Asian financial crisis of 1997 also brought corporate governance and accountability to the forefront. While several reforms have been implemented in the 
Asian region post the 1997 financial crises, it is also possible that the incidence of earnings management has increased in order to smooth the effects of the crisis.

\subsubsection{Sample selection}

The selection procedure followed two stages. The first stage commenced with selecting all countries in the OSIRIS database. Only countries with at least 90 firmyear observations were selected in order to ensure sufficient observations to carry out the tests planned for the study.

In the second stage, regulated, financial and mining industries were excluded from the sample (Table 4-1). These industries are excluded for the following reasons:

\section{$\underline{\text { Table } 4 \text {-1: Sample Selection }}$}

Total number of observations (1998-2007) 505594

Less: Missing values on dependent and independent variables

Less: Financial Institution

Less: Energy and mining sector

Less: top and bottom $1 \%$ of DACCR accruals

Less: \# of observations with | Studentized residuals $\mid>3$

Final \# of observations used in the tests

(i) Revenues in regulated industries are often set on accounting rates of return, which gives firms an incentive to adopt conservative accounting practices and thus defer income recognition. Given that the deferral of income recognition is common practice for regulated industries, it would be difficult to uncover opportunistic manipulation of earnings by management.

(ii) Financial entities such as banks and insurance companies are excluded because the structure of their assets and liabilities is different from firms in other industries and because in many countries, they are subject to different accounting 
regulations. These differences make problematic the estimation of discretionary accruals, as explained in prior empirical studies (Peasnell et al. 1998 and 2005; Chtourou et al. 2001; Bugshan 2005; Habib 2007; Francis and Wang 2008).

(iii) Mining firms also demonstrate significant differences from firms in other industries because of the unique nature of their assets. Such uniqueness includes heavy reliance on non-current assets, difference in inventory and receivables, dominance of intangibles, and frequent incidence of firms with negative equity. Another reason for excluding mining companies is that the empirical evidence indicates that investors recognise the value inherent in operating flexibility in the mining industry (Kelly 2004). Thus, the market value of mining firms differs from other firms in that it includes other major factors, such as the value of real operating options (Kelly 2004; Dixit and Pindyck 1994; Brennan and Schwartz 1985).

Pooled OLS regression is used to estimate discretionary accruals; it is therefore necessary to include only countries with sufficient firm observations to ensure reasonable precision in the parameter estimates. Following prior research (Francis and Wang 2008 and Cai et al. 2008), countries with less than 90 observations were dropped from the sample. Due to the sensitivity of regressions to extreme values, outlier observations were deleted from the sample.

\subsection{Operationalisation of the constructs}

\subsubsection{Macro governance}

Operationalisation of macro governance attributes follows the practices previously applied in the literature. The following table shows the operationalisation of the macro governance variables. 
Table 4-2: Operationalisation of explaining constructs (macro)

\begin{tabular}{|c|c|c|}
\hline & & Macro governance \\
\hline Variables & Symbols & Operationalisation \\
\hline \multirow[t]{6}{*}{ (1) Enforcement } & JUD & $\begin{array}{l}\text { Assessment of the efficiency and integrity of legal environment } \\
\text { as it affects businesses. Scale ranges from } 1 \text { to } 7 \text {, with lower } \\
\text { scores signifying lower efficiency levels. The World Economic } \\
\text { Forum (2008). }\end{array}$ \\
\hline & SEC & $\begin{array}{l}\text { An aggregate measure of regulation of securities exchanges in } \\
\text { the respective country and ranges from } 1 \text { to } 7 \text {, with } 1 \text { signifying } \\
\text { not transparent, ineffective, and subject to undue influence } \\
\text { from industry and government; and } 7 \text { signifying transparent, } \\
\text { effective and independent of undue influence from industry and } \\
\text { government. The World Economic Forum (2008). }\end{array}$ \\
\hline & MIN & $\begin{array}{l}\text { A measure of the protection of the interest of minority } \\
\text { shareholders' and ranges from } 1 \text { to } 7 \text {, with } 1 \text { signifying not } \\
\text { protected by law and } 7 \text { signifying protected by law and actively } \\
\text { enforced. The World Economic Forum (2008). }\end{array}$ \\
\hline & $\mathrm{ACC}$ & $\begin{array}{l}\text { An aggregate measure of auditing and financial reporting } \\
\text { standards relevant to company financial performance and } \\
\text { ranging from } 1 \text { to } 7 \text {, with } 1 \text { signifying extremely weak and } 7 \\
\text { signifying extremely strong enforcement. The World Economic } \\
\text { Forum (2008). }\end{array}$ \\
\hline & RLAW & $\begin{array}{l}\text { Measures the extent to which agents have confidence in and } \\
\text { abide by the rules of society, and in particular, the quality of } \\
\text { contract enforcement, the police, and the courts, as well as } \\
\text { likelihood of crime and violence. It ranges from }-1.39 \text { to } 2.03 \text {, } \\
\text { with higher scores indicating strong rule of law and vice-versa. } \\
\text { The World Bank (1999-2007). }\end{array}$ \\
\hline & PRESS & $\begin{array}{l}\text { Measures the extent to which a country's citizens are able to } \\
\text { participate in selection of their government, as well as enjoy } \\
\text { freedom of expression, freedom of association and a free media. } \\
\text { It ranges from }-1.66 \text { to } 1.72 \text {, with higher scores indicating } \\
\text { freedom of association and a free media and vice-versa. The } \\
\text { World Bank (1999-2007). }\end{array}$ \\
\hline $\begin{array}{l}\text { (2) Institutional } \\
\text { setting }\end{array}$ & INS & $\begin{array}{l}\text { It measures the ability of the government to formulate and } \\
\text { implement sound policies and regulations that permit and } \\
\text { promote private sector development. It ranges from }-1.35 \text { to } \\
1.85 \text {, with higher scores indicating strong institutional setting } \\
\text { and vice-versa. The World Bank (1999-2007). }\end{array}$ \\
\hline
\end{tabular}




\begin{tabular}{|l|l|l|}
\hline $\begin{array}{l}\text { (3) Political } \\
\text { system }\end{array}$ & POL & $\begin{array}{l}\text { Measures the perception of the likelihood that the government } \\
\text { will be destabilized or overthrown by unconstitutional or violent } \\
\text { means, including politically-motivated violence and terrorism. It } \\
\text { ranges from -1.99 to 1.51, with higher scores indicating greater } \\
\text { political stability and control and vice-versa. The World Bank } \\
\text { (1999-2007). }\end{array}$ \\
\hline (4) Corruption & COR & $\begin{array}{l}\text { Measures the perception of the extent to which public power is } \\
\text { exercised for private gain, including both petty and grand forms } \\
\text { of corruption, as well as "capture" of the state by elites and } \\
\text { private interests. It ranges from -1.29 to 2.57, with higher scores } \\
\text { indicating least corrupt practices taking place and vice-versa. } \\
\text { The World Bank (1999-2007). }\end{array}$ \\
\hline (5) Culture & CUL & $\begin{array}{l}\text { An aggregate measure of the corporate ethics (ethical behaviour } \\
\text { in interactions with public officials, politicians, and other } \\
\text { enterprises) of firms in the country, ranging from 1 to 7, with 1 } \\
\text { signifying among the world worst, and 7 signifying among the } \\
\text { best in the world. The World Economic Forum (2008). }\end{array}$ \\
\hline (6) IFRS adoption & IFRS & $\begin{array}{l}\text { A dummy variable that takes the value of 1 for a given country } \\
\text { in the years after mandatory IFRS adoption and 0 otherwise. } \\
\text { Deloite IAS Plus Website (2008). }\end{array}$ \\
\hline
\end{tabular}




\subsubsection{Micro governance}

Micro governance attributes are operationlized following existing practice in the literature. The following table shows the operationalisation of the micro governance variables.

Table 4-3: Operationalisation of explaining constructs (micro)

\begin{tabular}{|c|c|c|}
\hline \multicolumn{3}{|r|}{ Micro governance } \\
\hline Variables & Symbols & Operationalisation \\
\hline $\begin{array}{l}\text { (1) Capital market } \\
\text { transaction } \\
\text { motive }\end{array}$ & IPO & $\begin{array}{l}\text { Total IPO (Initial public offerings) proceeds as a } \\
\text { percentage of GDP. The World Economic Forum (2008). }\end{array}$ \\
\hline (2) Debt contracts & LEV & Total long-term debt/equity. OSIRIS (2009). \\
\hline $\begin{array}{l}\text { (3) Performance based } \\
\text { compensation }\end{array}$ & BONUS & $\begin{array}{l}\text { An aggregate measure of management compensation } \\
\text { package and ranging from } 1 \text { to } 7 \text {, with } 1 \text { signifying } \\
\text { compensation exclusively on salary and } 7 \text { signifying that } \\
\text { a larger part of income is derived from performance-based } \\
\text { benefits (bonus, stock options, etc.). The World Economic } \\
\text { Forum (2008). }\end{array}$ \\
\hline (4) Auditor quality & BIG4 & $\begin{array}{l}\text { Dummy variable with the value of } 1 \text { if the firm is audited } \\
\text { by one of the BIG } 4 \text { and } 0 \text { otherwise. OSIRIS (2009). }\end{array}$ \\
\hline (5) Board size & BOD & No. of directors on the board of a firm. OSIRIS (2009). \\
\hline (6) Board effectiveness & BIND & $\begin{array}{l}\text { A measure of corporate governance by investors and } \\
\text { boards of directors in the country, characterized by } 1 \text { to } 7 \text {, } \\
\text { with } 1 \text { signifying management has little accountability } \\
\text { and } 7 \text { signifying investors and boards exert strong } \\
\text { supervision of management decisions. The World } \\
\text { Economic Forum (2008). }\end{array}$ \\
\hline $\begin{array}{l}\text { (7) Ownership } \\
\text { concentration }\end{array}$ & OWN & $\begin{array}{l}\text { Measured as the median percentage of common shares } \\
\text { owned by the top } 3 \text { shareholders in the ten largest } \\
\text { privately owned non-financial firms in a given country. } \\
\text { High values stand for higher ownership concentration and } \\
\text { vice-versa. La Porta et al. (1998 and 2006) }\end{array}$ \\
\hline
\end{tabular}




\subsubsection{Earnings management}

Even though researchers are quite certain earnings management exist, it has been difficult to convincingly document it. Healy and Wahlen (1999) succinctly point it out by commenting that:

"Despite the popular wisdom that earnings management exists, it has been remarkably difficult for researchers to convincingly document it. The problem arises primarily because to identify whether earnings have been managed, researchers first have to estimate earnings before the effects of earnings management. This is not an easy task. One common approach is to first identify condition in which managers' inducement to manage earnings are likely to be strong, and then test whether pattern of unexpected accruals (or accounting choices) are consistent with these incentives (italics added)".

This study tests for earnings management by the three tests described above and in each case discretionary accruals is used as the measure of earnings management. ${ }^{17}$

McNichols (2000) discusses three research designs commonly used in the earnings management literature, which are shown in the following table. McNichols (2000) argues that selecting a research design to measure earnings management depends on the question addressed by the research. Two of the three research designs focus on accruals management rather than earnings management, because of the following:

(i) Cash earnings are less likely to be managed, because they are harder to manipulate.

(ii) Accruals are the favoured instrument for earnings management (Schipper 1989; Burilovich and Kattelus 1997; Ronen and Yaari 2008).

17 While opportunistic accrual management is often difficult to observe directly, analysis of patterns in accruals may reveal to investors that cash flow changes move in a different direction from accruals (Ayres 1994). 
Table 4-4: Research designs from the earnings management literature.

\begin{tabular}{|l|l|}
\hline $\begin{array}{l}\text { Research design in the } \\
\text { earnings management } \\
\text { literature. }\end{array}$ & \multicolumn{1}{|c|}{ Studies implementing the design. } \\
\hline Aggregate Accruals Models & $\begin{array}{l}\text { (Francis and Wang 2008; Habib 2008; Kothari et al. 2005; } \\
\text { DuCharme et al. 2001; Erickson and Wang 1999; DeFond and } \\
\text { Subramanyam 1998; Becker et al. 1998; Han and Wang 1998; } \\
\text { Dechow et al. 1995; Jones 1991; DeAngelo 1986; Healy 1985). }\end{array}$ \\
\hline Specific Accrual Models & $\begin{array}{l}\text { (Beaver and McNichols 1998; Beneish 1997; Beaver and Engel } \\
\text { 1996; Petroni 1992; McNichols and Wilson 1988). }\end{array}$ \\
\hline $\begin{array}{l}\text { Frequency Distribution } \\
\text { Approach }\end{array}$ & $\begin{array}{l}\text { (DeGeorge et al. 1999; Myers and Skinner 1999; Burgstahler and } \\
\text { Dichev1997). }\end{array}$ \\
\hline
\end{tabular}

McNichols (2000) provides the following reasons to justify the selection of the aggregate accruals approach over specific accruals approach:

(i) The aggregate accruals approach allows for control of additional variables, while the specific accruals models' approach is not flexible in investigating additional variables (i.e. micro and macro governance).

(ii) Aggregate accruals model may help the generalizability of the findings, because the number of firms for which a specific accrual is managed may be small relative to the number of firms with aggregate accruals (Beneish 2001).

(iii) If it is not clear which accruals management might be used to manage earnings, then the power of a specific accruals test for earnings management is reduced. $^{18}$

18 Prior studies do not specify any accruals item that is specifically associated with corporate governance attributes; and therefore does not promote the use of specific accrual models in corporate governance studies. 
(iv) If the aim is to examine the association between earnings management and other hypothesised factors, then a specific accruals model is less tractable because it requires a separate model for each accrual likely to be influenced by the hypothesised factors.

(v) Finally, the large number of studies published using aggregate accruals models indicates the wide acceptance of the aggregate accruals approach as a proper proxy for earnings management.

The aggregate accruals approach is selected over the frequency distribution approach for the following reasons:

(i) The frequency distribution approach can only be justified where there is a known symmetrical distribution for the data in question (Holland 2004).

(ii) There is no clear evidence supporting the constant assumption that the discontinuities at zero in the frequency distribution approach are due to earnings management (Durtschi and Easton 2004).

(iii) The frequency distribution approach measures discretion over earnings as the behaviour of earnings after they are managed.

(iv) The frequency distribution approach does not differentiate between discretionary and non-discretionary accruals (McNichols 2000).

(v) The frequency distribution approach provides results specifying which group of firms will manage earnings rather than forming a better measure of discretionary accruals (McNichols 2000).

The aggregate accruals approach is selected due to three factors. First, it captures the net effect of all accounting estimates and choices that influence reported earnings. This factor is needed because the governance literature does not specify the 
accounting manipulations meaningfully related to governance. Second, examining the behaviour of total discretionary accruals fulfils the need to measure whether managers had an incentive to manage earnings. Managers only manage earnings when they have an incentive to do so (Dechow et al. 2000; DeGeorge et al. 1999). Finally, the aggregate accruals approach has been the primary focus of earnings management studies measuring opportunistic earnings management (McNichols 2000).

\subsubsection{Aggregate accruals model}

Accruals modify the timing of accounting earnings and are composed of discretionary and non-discretionary accruals (Healy 1985). Extant research documents that firms use discretionary accruals to exercise earnings management (Kasznik 1999; Hall and Johan 1997; Robinson and Grant 1997; Dechow et al. 1995; Gaver et al. 1995; Holthausen et al. 1995; Warfield et al. 1995; DeFond and Jiambalvo 1994; Perry and Williams 1994; Sweeny 1994; Cahan 1992; Jones 1991).

While non-discretionary accruals represents accruals allowed by accounting standard setting bodies and are beyond the control of management, discretionary accruals enable managers to transfer earnings between periods and is proxy for earnings management (Healy 1985; Teoh et al. 1998a and 1998b). The most commonly used discretionary accruals models by empirical studies in the area of earnings management are the Jones (1991) and the modified Jones (Dechow et al. 1995) models (Kothari et al. 2005; Bartov et al. 2000; Thomas and Zhang 2000; Kasznik 1999; Becker et al. 1998; Beneish 1997; Guay et al. 1996; Subramanyam 
1996; Dechow et al. 1995; DeFond and Jiambalvo 1994). Table 4-5 summarises the description and the limitation of each of the models.

Table 4-5: Discretionary accruals models

\begin{tabular}{|l|l|l|}
\hline \multicolumn{1}{|c|}{ Model } & \multicolumn{1}{|c|}{ Description } & \multicolumn{1}{|c|}{ Limitations } \\
\hline Jones (1991) & $\begin{array}{l}\text { Expresses accruals as a function of } \\
\text { changes in sales revenue and the } \\
\text { level of gross total property, plant, } \\
\text { and equipment (PPE). }\end{array}$ & $\begin{array}{l}\text { It assumes that revenues are unmanaged. } \\
\text { It may provide biased accruals, because it } \\
\text { omits expenses. }\end{array}$ \\
\hline $\begin{array}{l}\text { Modified Jones } \\
\text { model } \\
\text { (Dechow } \\
\text { et al. 1995) }\end{array}$ & $\begin{array}{l}\text { It attempts to mitigate potential bias } \\
\text { from assuming manipulation-free } \\
\text { revenues. }\end{array}$ & $\begin{array}{l}\text { It assumes that all changes in credit sales } \\
\text { aresults of earnings management } \\
\text { activity. It also may provide biased } \\
\text { accruals, because it omits expenses. }\end{array}$ \\
\hline
\end{tabular}

A number of researchers argue that only the Jones and the modified Jones models appear to have the potential to provide reliable estimates of discretionary accruals (Kothari 2001; Guay et al. 1996; Subramanyam 1996; Dechow et al. 1995).

Few of the proposed earnings management models proposed by accounting researchers have received as much attention as Jones (1991) model. The following are noteworthy in terms of the earnings management empirical model development milestones:

(i) Healy (1985) shows that compensation contracts may induce management to take measures to decrease reported income when it cannot increase its bonus, thus hoarding reported income.

(ii) Schipper (1989) provides a discussion of the different definitions of earnings management and critically summarizes recent empirical developments. Her commentary appeared after a Journal of Accounting Research conference, Studies on Managements' Ability and Incentives to Affect the Timing and Magnitude of 
Accounting Accruals. The most cited paper from this conference in the earnings management literature is by McNichols and Wilson (1988), on manipulation of the bad-debt expense.

(iii) Jones (1991) separates discretionary accruals from non-discretionary accruals when she examined the demand of regulators for earnings information during import relief investigations; the same approach to detecting earnings management has been examined further by Dechow et al. (1995); Bartov et al.(2000); Dechow and Dichev (2002); Kang (2005); Kothari et al. (2005); Ye (2006) and Yaari et al. (2007).

\subsubsection{1. (i) Jones (1991) model}

Jones (1991) is motivated to confine a larger portion of managers' manipulations rather than selecting a single accrual account as suggested by McNichols and Wilson (1988). Jones (1991) argues that accruals are influenced by economic circumstances. Jones (1991) attempts to control for the effect of changing economic conditions on accounting accruals by controlling changes in non-discretionary accruals. While sales growth controls a firms' non-discretionary working capital, the level of property, plant, and equipment controls the firms' non-discretionary depreciation expense (Bernard and Skinner 1996). Jones (1991) uses the discretionary portion of total accruals to capture earnings management.

\subsubsection{1. (ii) Modified Jones (Dechow et al. 1995) model}

Dechow et al. (1995) explain that a weakness of the Jones (1991) model lies in its inability to capture the impact of sales-based manipulations, because Jones (1991) 
assumes changes in sales are associated with non-discretionary accruals. Dechow et al. (1995) proposes a modification that would help detect sales-based earnings management. While Jones (1991) implicitly assumes that revenues are nondiscretionary, Dechow et al. (1995) assumes that only collected revenues are nondiscretionary. Dechow et al. (1995) modifies the Jones model by eliminating errors caused when discretion is exercised over revenue through credit sales.

The Jones (1991) and Dechow et al. (1995) models are time series. However, recent studies (DeFond and Jiambalvo 1994; Subramanyam 1996; DeFond and Subramanyam 1998; Becker et al. 1998; Peasnall et al. 1998; Teoh et al. 1998a and 1998b; Bartov et al. 2000) prefer cross-sectional discretionary accruals models to time-series models for the following reasons:

(i) The cross-sectional model generates a larger sample (Peasnell et al. 2005 and Subramanyam 1996).

(ii) The number of observations per model is consistently higher for the cross sectional model (Subramanyam 1996; Peasnell et al. 2005). Some studies resort to using a pooled sample (Erickson and Wang 1999; Cahan 1992; Han and Wang 1998; Hribar and Collins 2002; and Park and Park 2004).

(iii) Since the estimation period of time series model is at least ten years, it is possible for the model to be miss-specified due to being non-stationary ( Peasnell et al. 2005)

(iv) Use of time series lowers the power of tests which examine time series behavior in discretionary accruals, because of possible overlaps in estimation and treatment periods Bartov et al. (2000). 
The above reasoning justifies the selection of the cross-sectional model in performance to time-series model.

\subsubsection{Cross-sectional models}

The cross-sectional approach adjusts for changing industry wide economic conditions, which influence accruals independently of earnings management (Teoh et al. 1998a \& 1998b). However, this is based on the assumption that all firms in the industry have a similar operating cycle. Recent studies measure discretionary accruals using cross-sectional models (DeFond and Jiambalvo 1994; Subramanyam 1996; DeFond and Subramanyam 1998; Becker et al. 1998; Francis et al. 1999; Chambers 1999; Teoh et al. 1998 and 1998 ; Kasznik 1999; Klein 2000b; Bartov et al. 2000; Chtourou et al. 2001; Kothari, S. 2001; Xie et al. 2003; Bedard et al. 2004; Kang 2005; Kothari et al. 2005). Details of the application of the cross-sectional Jones (1991) and modified Jones (Dechow et al. 1995) models are set out below.

\subsubsection{2. (i) Cross-sectional Jones model}

Discretionary accruals are measured in two steps. Firstly, the Jones model measures nondiscretionary accruals as a function of the level of property, plant and equipment, and changes in revenue. All variables in the accruals expectations model are scaled by lagged assets to reduce heteroskedasticity (Jones 1991). 
Equation (iv): Cross-sectional Jones (1991) non-discretionary accruals model

$\mathrm{TA}_{\mathrm{it}} / \mathrm{A}_{\mathrm{it}-1}=\beta_{0}\left(1 / \mathrm{A}_{\mathrm{it}-1}\right)+\beta_{1}\left(\Delta \mathrm{REV}_{\mathrm{it}} / \mathrm{A}_{\mathrm{it}-1}\right)+\beta_{2}\left(\mathrm{PPE}_{\mathrm{it}} / \mathrm{A}_{\mathrm{it}-1}\right)+\varepsilon$

where

$\mathrm{TA}_{\mathrm{it}}$ is total accruals,

$\triangle \mathrm{REV}_{\mathrm{it}}$ is the change in revenue of firm $\mathrm{i}$, for the period ${ }_{\mathrm{t}-1}$ to $\mathrm{t}$.

$\mathrm{PPE}_{\mathrm{it}}$ is gross property, plant, and equipment of firm of firm $\mathrm{i}$, for the period ${ }_{t}$, all scaled by the lagged total assets.

Discretionary accruals for each sample firm $i$, are estimated as the residual from Equation (iv). That is,

Equation (v): Cross-sectional Jones (1991) discretionary accruals model

$\operatorname{DACCR}_{\mathrm{it}} / \mathrm{A}_{\mathrm{it}-1}=\mathrm{TA}_{\mathrm{it}} / \mathrm{A}_{\mathrm{it}-1}-\left[\beta_{0}\left(1 / \mathrm{A}_{\mathrm{it}-1}\right)+\beta_{1}\left(\Delta \mathrm{REV} \mathrm{V}_{\mathrm{it}} / \mathrm{A}_{\mathrm{it}-1}\right)+\beta_{2}\left(\mathrm{PPE}_{\mathrm{it}} / \mathrm{A}_{\mathrm{it}-1}\right)\right]$

where,

$\mathrm{DACCR}_{\mathrm{it}}=$ discretionary accruals as measured by the difference between total accruals and predicted total accruals.

$\beta_{0}, \beta_{1}$, and $\beta_{2}$ are the fitted coefficients from Equation (iv).

\subsubsection{2. (ii) Cross-sectional modified Jones model}

The extension that Dechow et al. (1995) made to the original Jones (1991) model was to adjust the change in revenues for the change in receivables in the event period.

Equation (vi): Dechow et al. (1995) modification of the cross-sectional Jones model

$\mathrm{TA}_{\mathrm{it}} / \mathrm{A}_{\mathrm{it}-1}=\alpha_{0}\left(1 / \mathrm{A}_{\mathrm{it}-1}\right)+\alpha_{1}\left(\Delta \mathrm{REV}_{\mathrm{it}}-\Delta \mathrm{REC}_{\mathrm{it}} / \mathrm{A}_{\mathrm{it}-1}\right)+\alpha_{2}\left(\mathrm{PPE}_{\mathrm{it}} / \mathrm{A}_{\mathrm{it}-1}\right)+\varepsilon$

Equation (vii): Dechow et al. (1995) modification of the cross-sectional Jones model

$\mathrm{DACCR}_{\mathrm{it}} / \mathrm{A}_{\mathrm{it}-1}=\mathrm{TA}_{\mathrm{it}} / \mathrm{A}_{\mathrm{it}-1}-\left[\dot{\alpha}_{0}\left(1 / \mathrm{A}_{\mathrm{it}-1}\right)+\dot{\alpha}_{1}\left(\Delta \mathrm{REV} \mathrm{it}_{\mathrm{it}}-\Delta \mathrm{REC}_{\mathrm{it}} / \mathrm{A}_{\mathrm{it}-1}\right)+\dot{\alpha}_{2}\left(\mathrm{PPE}_{\mathrm{it}} / \mathrm{A}_{\mathrm{it}-1}\right)\right]$

where

$\dot{\alpha}_{0}, \dot{\alpha}_{1}$, and $\dot{\alpha}_{2}$ are the fitted coefficients from equation (vi). 
In Equation (vii), the coefficients estimated from Equation (vi) are used to predict expected total accruals. Expected total accruals are deducted from actual total accruals $\left(\mathrm{TA}_{\mathrm{it}} / \mathrm{A}_{\mathrm{it}-1}\right)$ to obtain discretionary accruals $\left(\mathrm{DACCR}_{\mathrm{it}} / \mathrm{A}_{\mathrm{it}-1}\right)$.The effectiveness of the model in measuring earnings management depends on how well discretionary accruals are separated from nondiscretionary accruals. Dechow et al. (1995) conclude that their version of the modified Jones model is superior to all other currently available models, though it remains imperfect. Subramanyam (1996) finds that results obtained from cross-sectional modified Jones model (Dechow et al. 1995) are qualitatively similar to the results obtained from cross-sectional Jones model. However, estimations cannot be very precise.

Subramanyam (1996) argues that cross-sectional models are not free of measurement problems, similar to all other discretionary accruals models. It can be argued that the Jones (1991) and the modified Jones (Dechow et al. 1995) models misclassify discretionary and non-discretionary accruals. However, Bernard and Skinner (1996) state that the misclassification problem is common to all earnings management studies.

The present study focuses on discretionary accruals from the modified Jones (Dechow et al. 1995) model as the key measure for earnings management for two reasons. First, the results obtained from the modified cross-sectional Jones model are qualitatively similar to the results obtained from cross-sectional Jones model (Subramanyam 1996). Second, the modified Jones (Dechow et al. 1995) model eliminates errors caused when discretion is exercised over revenue through credit sales. 


\subsubsection{Measuring total accruals}

To be able to estimate discretionary accruals, total accruals need to be computed. There are two methods for computing total accruals. The first method is the traditional balance sheet approach that has been used in the majority of prior studies

(Healy 1985; Jones 1991; Dechow et al. 1995; Peasnell et al. 1998; Kothari 2001).

The second method is the cash flow approach (Yaari et al. 2007; Subramanyam 1996;

DeFond and Subramanyam 1997; Becker et al. 1998; Klein 2002b).

Under the traditional balance sheet approach, total accruals are measured as follows:

Equation (viii): Balance sheet approach.

TA $=(\Delta \mathrm{CA}-\Delta \mathrm{Cash})-(\Delta \mathrm{CL}-\Delta \mathrm{STD})-$ depreciation. (viii)

where

TA represents total Accruals

$\Delta \mathrm{CA}$ represents change in current assets

$\Delta$ Cash denotes change in cash and cash equivalents

$\triangle \mathrm{CL}$ denotes change in current liabilities, and

$\Delta$ STD refers to change in short-term debt included in current liabilities.

Under the cash flow approach, total accruals are measured as follows:

Equation (ix): Cash flow approach

TA $=$ EBIT - OCF

where

TA represents total accruals,

EBIT represents earnings before interest and taxes, and

OCF denotes operating cash flow.

However, recent studies prefer the cash flow approach to the traditional balance sheet approach because of the following reasons: 
(i) The balance sheet approach omits non-current accruals (except for deprecation and amortisation), the cash flow approach accounts for both current and non-current accruals.

(ii)The balance sheet approach is less efficient than the cash flow approach when firms experience mergers or acquisitions (Collins and Hribar 2002).

(iii) The balance sheet approach is biased in measuring accruals for firms experiencing discontinuing operations (Collins and Hribar 2002).

Collins and Hribar (2002) point out that the frequency and magnitude of errors introduced when using the balance sheet approach can be substantial. For the reasons discussed above, the cash flow approach is used in the present study to calculate total accruals. ${ }^{19}$

Total accruals', using the cash flow approach, is divided into discretionary and non-discretionary accruals by using the modified Jones model. The level of discretionary accruals is then used as the empirical indicator of earnings management.

\subsection{Analytical procedures}

The analysis of the data was carried out in four distinct steps. Each of these steps and the associated research question to be tested is outlined below:

\subsubsection{Step one: Data collection and descriptive statistics}

Data for this study were collected from a combination of sources-all secondary. Firmlevel accounting data were collected from the OSIRIS database while country-level

19 Data results support Collins and Hribar's (2002) findings that the cash flow approach has less bias than the balance sheet approach. 
data were collected from the World Economic Forum and The World Bank. Descriptive statistics are computed to profile the data.

\subsubsection{Step two: Computing discretionary accruals}

The second step of the analysis is to compute discretionary accruals. As mentioned above, the study uses the modified Jones (Dechow et al. 1995) model to compute discretionary accruals. Estimation of discretionary accruals involves two steps. First nondiscretionary accruals are estimated using the cross-sectional version of the modified Jones model, as in Krishnan (2003a). This model estimates total accruals as a function of the change in revenue (adjusted for the change in receivables) and the level of property, plant and equipment. Further, a correlation analysis is performed to examine the relationship between the dependent and independent variables. This test examines the extent to which the dependent variable is related to each of the independent variables in the study. Prior to conducting the correlation analysis, the variables are examined to check for distributions.

\subsubsection{Step three: Regression analysis}

The proposed models are tested using both pooled and year-wise specifications of pooled OLS regression. To test the effect of governance on earnings management, this study regress the DACCR on governance and a number of control variables.

\subsubsection{Step four: Robustness checks}

The fourth step in the analysis is to test the regression assumptions and adjust the data for outliers and test for collinearity. For example, the regression assumptions are 
tested by examining the residuals of the model (Pedhazur 1997). The assumptions are: normality, linearity, homoskedasticity, and independence of residuals (Pedhazur 1997).

Distributions with infinite variance tend to have thick tails, implying outliers (Malinvaud 1980; Rogers 1993). Relatively heavy weights can be placed on outliers (Judge et al. 1988). Thus, their presence tends to lead to bias and extremely sensitive least square estimates. Following prior studies (Francis and Wang 2008), if the earnings level or change in earnings, scaled by beginning total assets, is above 1.0 or below -1.0 , then it is considered to be an outlier. This approach is proposed by Malinvaud (1980) to transfer infinite variance into finite variance by assuming that the distribution of the disturbances is bounded.

Macro and micro governance attributes could be interrelated leading to collinearity problems. Several methods are employed to reduce the severity of collinearity problems.

\subsection{Research questions}

Table 4-6 below shows the list of research questions tested. In each case the effect of a single explanatory variable is tested. This is different from the test equations (i) and (ii) developed above. However, the data limitations in cross country studies are such that it is common to focus on one variable (or subsets of the variables) rather than incorporating all of them in a single test. The testing of multiple variables gives greater confidence if the results found are consistent across variables. When testing each research question, pooled regressions as well as year wise cross section are reported. The joint effect of macro and micro governance on earnings management is 
tested by using explanatory principal component analysis (PCA) to reduce the ten macro governance variables to a single composite variable.

Table 4-6

\section{Summary of research questions}

\begin{tabular}{|c|c|}
\hline $\begin{array}{l}\text { (1) Enforcement } \\
\text { Does a strong system of enforcement } \\
\text { affect earnings management? }\end{array}$ & $\begin{array}{l}\mathrm{DACCR}_{\mathrm{it}}=\beta_{0}+\beta_{1} \mathbf{E N F}+\beta_{2} \mathrm{SIZE}_{i t}+\beta_{3} \mathrm{LEV}_{\mathrm{it}}+\beta_{4} \mathrm{GWTH}_{\mathrm{it}} \\
+\beta_{5} \mathrm{CFO}_{\mathrm{it}}+\beta_{6} \mathrm{CAP}_{\mathrm{it}}+\beta_{7} \mathrm{LOSS}_{\mathrm{it}}+\text { fixed effects }\end{array}$ \\
\hline $\begin{array}{l}\text { (2) Institutional Setting } \\
\text { Does the institutional setting affect } \\
\text { earnings management? }\end{array}$ & $\begin{array}{l}\text { DACCR }_{\text {it }}=\beta_{0}+\beta_{1} \text { INS }+\beta_{2} \text { SIZE }_{i t}+\beta_{3} L_{E V} V_{i t}+\beta_{4} G_{W T H}+ \\
\beta_{5} \text { CFO }_{\text {it }}+\beta_{6} \text { CAP }_{\text {it }}+\beta_{7} \text { LOSS }_{\text {it }}+\text { fixed effects }\end{array}$ \\
\hline $\begin{array}{l}\text { (3) Political system } \\
\text { Does the political system affect } \\
\text { earnings management? }\end{array}$ & $\begin{array}{l}\mathrm{DACCR}_{\mathrm{it}}=\beta_{0}+\beta_{1} \mathbf{P O L}+\beta_{2} \mathrm{SIZE}_{\mathrm{it}}+\beta_{3} \mathrm{LEV}_{\mathrm{it}}+\beta_{4} \mathrm{GWTH}_{\mathrm{it}} \\
+\beta_{5} \mathrm{CFO}_{\mathrm{it}}+\beta_{6} \mathrm{CAP}_{\mathrm{it}}+\beta_{7} \mathrm{LOSS}_{\mathrm{it}}+\text { fixed effects }\end{array}$ \\
\hline $\begin{array}{l}\text { (4) Corruption } \\
\text { Does perceived corruption affect } \\
\text { earnings management? }\end{array}$ & $\begin{array}{l}\mathrm{DACCR}_{\mathrm{it}}=\beta_{0}+\beta_{1} \mathbf{C O R}+\beta_{2} \mathrm{SIZE}_{\mathrm{it}}+\beta_{3} \mathrm{LEV}_{\mathrm{it}}+\beta_{4} \mathrm{GWTH}_{\mathrm{it}} \\
+\beta_{5} \mathrm{CFO}_{\mathrm{it}}+\beta_{6} \mathrm{CAP}_{\mathrm{it}}+\beta_{7} \mathrm{LOSS}_{\mathrm{it}}+\text { fixed effects }\end{array}$ \\
\hline $\begin{array}{l}\text { (5) Culture } \\
\text { Does national culture affect earnings } \\
\text { management? }\end{array}$ & $\begin{array}{l}\mathrm{DACCR}_{\mathrm{it}}=\beta_{0}+\beta_{1} \mathbf{C U L}+\beta_{2} \mathrm{SIZE}_{\mathrm{it}}+\beta_{3} \mathrm{LEV}_{\mathrm{it}}+\beta_{4} \mathrm{GWTH}_{\mathrm{it}} \\
+\beta_{5} \mathrm{CFO}_{\mathrm{it}}+\beta_{6} \mathrm{CAP}_{\mathrm{it}}+\beta_{7} \mathrm{LOSS}_{\mathrm{it}}+\text { fixed effects }\end{array}$ \\
\hline $\begin{array}{l}\text { (6) IFRS } \\
\text { Does adoption of IFRS affect earnings } \\
\text { management? }\end{array}$ & $\begin{array}{l}\mathrm{DACCR}_{\mathrm{it}}=\beta_{0}+\beta_{1} \mathbf{I F R S}+\beta_{2} \mathrm{SIZE}_{\mathrm{it}}+\beta_{3} \mathrm{LEV}_{\mathrm{it}}+\beta_{4} \mathrm{GWTH}_{\mathrm{it}} \\
+{ }_{5} \mathrm{CFO}_{\mathrm{it}}+\beta_{6} \mathrm{CAP}_{\mathrm{it}}+\beta_{7} \mathrm{LOSS}_{\mathrm{it}}+\text { fixed effects }\end{array}$ \\
\hline $\begin{array}{l}\text { (7) IPO } \\
\text { Does manager manage earnings } \\
\text { during initial public offerings? }\end{array}$ & $\begin{array}{l}\text { DACCR }_{\text {it }}=\beta_{0}+\beta_{1} \mathbf{I P O}+\beta_{2} \mathrm{SIZE}_{\text {it }}+\beta_{3} \mathrm{LEV}_{\text {it }}+\beta_{4} \mathrm{GWTH}_{\mathrm{it}}+ \\
\beta_{5} \mathrm{CFO}_{\text {it }}+\beta_{6} \mathrm{CAP}_{\mathrm{it}}+\beta_{7} \mathrm{LOSS}_{\text {it }}+\text { fixed effects }\end{array}$ \\
\hline $\begin{array}{l}\text { (8) Debt contracts } \\
\text { Do managers manage earnings to } \\
\text { avoid violating debt covenants? }\end{array}$ & $\begin{array}{l}\mathrm{DACCR}_{\mathrm{it}}=\beta_{0}+\beta_{1} \mathbf{L E V}+\beta_{2} \mathrm{SIZE}_{\mathrm{it}}+\beta_{3} \mathrm{GWTH}_{\mathrm{it}}+\beta_{4} \mathrm{CFO}_{\mathrm{it}} \\
+\beta_{5} \mathrm{CAP}_{\mathrm{it}}+\beta_{6} \mathrm{LOSS}_{\mathrm{it}}+\text { fixed effects }\end{array}$ \\
\hline
\end{tabular}




\begin{tabular}{|c|c|}
\hline $\begin{array}{l}\text { (9) Performance based } \\
\text { compensations } \\
\text { Do managers manage earnings to } \\
\text { increase performance based } \\
\text { compensations? }\end{array}$ & $\begin{array}{l}\text { DACCR }_{\text {it }}=\beta_{0}+\beta_{1} \text { BONUS }+\beta_{2} \mathrm{SIZE}_{\mathrm{it}}+\beta_{3} \mathrm{LEV}_{\text {it }}+ \\
\beta_{4} \mathrm{GWTH}_{\mathrm{it}}+\beta_{5} \mathrm{CFO}_{\mathrm{it}}+\beta_{6} \mathrm{CAP}_{\mathrm{it}}+\beta_{7} \mathrm{LOSS}_{\mathrm{it}}+\text { fixed effects }\end{array}$ \\
\hline $\begin{array}{l}\text { (10) Audit quality } \\
\text { Do quality auditors affect earnings } \\
\text { management? }\end{array}$ & $\begin{array}{l}\mathrm{DACCR}_{\mathrm{it}}=\beta_{0}+\beta_{1} \mathrm{BIG} 4+\beta_{2} \mathrm{SIZE}_{\mathrm{it}}+\beta_{3} \mathrm{LEV}_{\mathrm{it}}+\beta_{4} \mathrm{GWTH}_{\mathrm{it}} \\
+\beta_{5} \mathrm{CFO}_{\mathrm{it}}+\beta_{6} \mathrm{CAP}_{\mathrm{it}}+\beta_{7} \mathrm{LOSS}_{\mathrm{it}}+\text { fixed effects }\end{array}$ \\
\hline $\begin{array}{l}\text { (11) Board size } \\
\text { Does board size affect earnings } \\
\text { management? }\end{array}$ & $\begin{array}{l}\text { DACCR }_{i t}=\beta_{0}+\beta_{1} \text { BOD }+\beta_{2} \text { SIZE }_{i t}+\beta_{3} \mathrm{LEV}_{\text {it }}+\beta_{4} \mathrm{GWTH}_{\text {it }} \\
+\beta_{5} \mathrm{CFO}_{\mathrm{it}}+\beta_{6} \mathrm{CAP}_{\mathrm{it}}+\beta_{7} \mathrm{LOSS}_{\mathrm{it}}+\text { fixed effects }\end{array}$ \\
\hline $\begin{array}{l}\text { (12) Board effectiveness } \\
\text { Does board effectiveness affect } \\
\text { earnings management? }\end{array}$ & $\begin{array}{l}\text { DACCR }_{\text {it }}=\beta_{0}+\beta_{1} \text { BIND }+\beta_{2} \text { SIZE }_{i t}+\beta_{3} \mathrm{LEV}_{\text {it }}+ \\
\beta_{4} \mathrm{GWTH}_{\text {it }}+\beta_{5} \mathrm{CFO}_{\mathrm{it}}+\beta_{6} \mathrm{CAP}_{\mathrm{it}}+\beta_{7} \mathrm{LOSS}_{\mathrm{it}}+\text { fixed effects }\end{array}$ \\
\hline $\begin{array}{l}\text { (13) Ownership concentration } \\
\text { Does higher concentration of } \\
\text { ownership affect earnings } \\
\text { management? }\end{array}$ & $\begin{array}{l}\mathrm{DACCR}_{\mathrm{it}}=\beta_{0}+\beta_{1} \mathrm{OWN}+\beta_{2} \mathrm{SIZE}_{\text {it }}+\beta_{3} \mathrm{LEV}_{\mathrm{it}}+\beta_{4} \mathrm{GWTH}_{\mathrm{it}} \\
+\beta_{5} \mathrm{CFO}_{\mathrm{it}}+\beta_{6} \mathrm{CAP}_{\mathrm{it}}+\beta_{7} \mathrm{LOSS}_{\mathrm{it}}+\text { fixed effects }\end{array}$ \\
\hline
\end{tabular}

\subsection{Summary}

This chapter has discussed the sample selection, data collection, and research question testing procedures. The chapter discussed the method used to test the research question, as developed in Chapter Three. It is clear that there is a friction regarding the economics of earnings management. The empirical research pays no attention to competition in product markets and other facets of business strategy, in that it assumes that controlling for industry and year in the regression analysis is 
sufficient to control for all these aspects ${ }^{20}$. As yet there is no consensus methodology that perfectly overcomes the challenge posed by the fact that unmanaged earnings are unobservable. However, the work of Ye (2006), which supports the Jones model, seems promising in this regard. Considering the above discussion on all the variables of the developed models of the study, Table 4-7 is reproduced with the expected sign of the coefficients below.

Table 4-7

\section{List of variables}

\begin{tabular}{|c|c|c|c|}
\hline Symbol & Variable & $\begin{array}{l}\text { Predicted } \\
\text { sign }\end{array}$ & Definition \\
\hline JUD & $\begin{array}{l}\text { Judicial } \\
\text { independence }\end{array}$ & - & $\begin{array}{l}\text { Assessment of the efficiency and integrity of legal } \\
\text { environment as it affects businesses. Scale ranges from } \\
1 \text { to } 7 \text {, with lower scores signifying lower efficiency } \\
\text { levels and vice versa. The World Economic Forum } \\
\text { (2008). }\end{array}$ \\
\hline SEC & $\begin{array}{l}\text { Regulation of } \\
\text { securities } \\
\text { enforcement }\end{array}$ & - & $\begin{array}{l}\text { An aggregate measure of regulation of securities } \\
\text { exchanges in the respective country and ranges from } 1 \\
\text { to } 7 \text {, with } 1 \text { signifying not transparent, ineffective, and } \\
\text { subject to undue influence from industry and } \\
\text { government; and } 7 \text { signifying transparent, effective and } \\
\text { independent of undue influence from industry and } \\
\text { government. The World Economic Forum (2008). }\end{array}$ \\
\hline MIN & $\begin{array}{l}\text { Protection of } \\
\text { minority } \\
\text { shareholders } \\
\text { right }\end{array}$ & - & $\begin{array}{l}\text { A measure of the protection of the interest of minority } \\
\text { shareholders' and ranges from } 1 \text { to } 7 \text {, with } 1 \text { signifying } \\
\text { not protected by law and } 7 \text { signifying protected by law } \\
\text { and actively enforced. The World Economic Forum } \\
\text { (2008). }\end{array}$ \\
\hline ACC & $\begin{array}{l}\text { Enforcement of } \\
\text { accounting and } \\
\text { auditing } \\
\text { standards }\end{array}$ & - & $\begin{array}{l}\text { An aggregate measure of auditing and financial } \\
\text { reporting standards relevant to company financial } \\
\text { performance and ranging from } 1 \text { to } 7 \text {, with } 1 \text { signifying } \\
\text { extremely weak and } 7 \text { signifying extremely strong } \\
\text { enforcement. The World Economic Forum (2008). }\end{array}$ \\
\hline
\end{tabular}

20 The economic repercussions of earnings management (on firm-level investment) are studied in Kedia and Philippon (2005) and McNichols and Stubben (2005) . 


\begin{tabular}{|c|c|c|c|}
\hline RLAW & Rule of Law & - & $\begin{array}{l}\text { Measures the extent to which agents have confidence in } \\
\text { and abide by the rules of society, and in particular, the } \\
\text { quality of contract enforcement, the police, and the } \\
\text { courts, as well as likelihood of crime and violence. It } \\
\text { ranges from }-13.9 \text { to } 2.03 \text {, with higher scores indicating } \\
\text { strong rule of law and vice-versa. The World Bank } \\
(1999-2007) \text {. }\end{array}$ \\
\hline PRESS & Press freedom & - & $\begin{array}{l}\text { Measures the extent to which a country's citizens are } \\
\text { able to participate in selection of their government, as } \\
\text { well as enjoy freedom of expression, freedom of } \\
\text { association and a free media. It ranges from - } 1.66 \text { to } \\
1.72 \text {, with higher scores indicating greater participation } \\
\text { and freedom and vice versa. The World Bank (1999- } \\
\text { 2006). }\end{array}$ \\
\hline INS & $\begin{array}{l}\text { Institutional } \\
\text { setting }\end{array}$ & - & $\begin{array}{l}\text { Measures the ability of the government to formulate } \\
\text { and implement sound policies and regulations that } \\
\text { permit and promote private sector development. It } \\
\text { ranges from }-1.35 \text { to } 1.85 \text {, with higher scores indicating } \\
\text { greater potential for government to create an } \\
\text { environment conducive to economic development and } \\
\text { vice versa. The World Bank (1999-2007). }\end{array}$ \\
\hline POL & $\begin{array}{l}\text { Political } \\
\text { system }\end{array}$ & - & $\begin{array}{l}\text { Measures the perception of the likelihood that the } \\
\text { government will be destabilized or overthrown by } \\
\text { unconstitutional or violent means, including politically- } \\
\text { motivated violence and terrorism. It ranges from }-1.99 \\
\text { to } 1.51 \text {, with higher scores indicating greater political } \\
\text { stability and control and vice versa. The World Bank } \\
\text { (1999-2007). }\end{array}$ \\
\hline COR & Corruption & - & $\begin{array}{l}\text { Measures the perception of the extent to which public } \\
\text { power is exercised for private gain, including both petty } \\
\text { and grand forms of corruption, as well as "capture" of } \\
\text { the state by elites and private interests. It ranges from - } \\
1.29 \text { to } 2.57 \text {, with higher scores indicating least corrupt } \\
\text { practices taking place and vice versa. The World Bank } \\
(1999-2007) \text {. }\end{array}$ \\
\hline CUL & National culture & - & $\begin{array}{l}\text { An aggregate measure of the corporate ethics (ethical } \\
\text { behaviour in interactions with public officials, } \\
\text { politicians, and other enterprises) of firms in the } \\
\text { country, ranging from } 1 \text { to } 7 \text {, with } 1 \text { signifying among } \\
\text { the world worst, and } 7 \text { signifying among the best in the } \\
\text { world. World Economic Forum (2008). }\end{array}$ \\
\hline IFRS & IFRS Adoption & - & A dummy variable that takes the value of 1 for a given \\
\hline
\end{tabular}




\begin{tabular}{|c|c|c|c|}
\hline & & & $\begin{array}{l}\text { country in the years after mandatory IFRS adoption and } \\
0 \text { otherwise. Deloite IAS Plus Website (2008). }\end{array}$ \\
\hline IPO & $\begin{array}{l}\text { Capital market } \\
\text { transaction } \\
\text { motive }\end{array}$ & + & $\begin{array}{l}\text { Total IPO (Initial public offerings) proceeds as a } \\
\text { percentage of GDP. World Economic Forum (2008). }\end{array}$ \\
\hline LEV & Debt contract & + & Total long-term debt/ total equity \\
\hline BONUS & $\begin{array}{l}\text { Performance } \\
\text { based } \\
\text { compensations }\end{array}$ & - & $\begin{array}{l}\text { An aggregate measure of management compensation } \\
\text { package and ranges from } 1 \text { to } 7 \text {, with } 1 \text { signifying } \\
\text { compensation exclusively on salary and } 7 \text { signifying } \\
\text { that a larger part of income is derived from } \\
\text { performance-based benefits (bonus, stock options, etc.) } \\
\text { The World Economic Forum (2008). }\end{array}$ \\
\hline BIG4 & Auditor quality & - & $\begin{array}{l}\text { Dummy variable with the value of } 1 \text { if the firm is } \\
\text { audited by one of the BIG } 4 \text { and } 0 \text { otherwise. OSIRIS } \\
\text { (2009). }\end{array}$ \\
\hline BOD & Board Size & - & No. of directors on the board of a firm. OSIRIS (2009). \\
\hline BIND & $\begin{array}{l}\text { Board } \\
\text { independence }\end{array}$ & - & $\begin{array}{l}\text { A measure of corporate governance by investors and } \\
\text { boards of directors in the country, characterized by } 1 \text { to } \\
7 \text {, with } 1 \text { signifying management has little } \\
\text { accountability and } 7 \text { signifying investors and boards } \\
\text { exert strong supervision of management decisions. The } \\
\text { World Economic Forum (2008). }\end{array}$ \\
\hline OWN & $\begin{array}{l}\text { Ownership } \\
\text { concentration }\end{array}$ & + & $\begin{array}{l}\text { Measured as the median percentage of common shares } \\
\text { owned by the top } 3 \text { shareholders in the ten largest } \\
\text { privately owned non-financial firms in a given country. } \\
\text { High values stand for higher ownership concentration. } \\
\text { La Porta et al. (1998 and 2006) }\end{array}$ \\
\hline DACCR & $\begin{array}{l}\text { Discretionary } \\
\text { accruals }\end{array}$ & & $\begin{array}{l}\text { Discretionary accruals under modified (Dechow et al. } \\
\text { 1995) Jones model }\end{array}$ \\
\hline SIZE & Firm size & + & Natural log of firm total assets \\
\hline GWTH & $\begin{array}{l}\text { Return on } \\
\text { equity }\end{array}$ & + & Net income / Total equity \\
\hline $\mathrm{CFO}$ & $\begin{array}{l}\text { Cash flow from } \\
\text { operations }\end{array}$ & - & Cash flow from operations \\
\hline CAP & Capital & $+/-$ & Non-current (fixed) assets/ Total assets \\
\hline
\end{tabular}




\begin{tabular}{|l|l|l|l|}
\hline LOSS & intensity & & \\
\hline$\Delta$ REC & $\begin{array}{l}\text { Change in } \\
\text { receivables }\end{array}$ & $+/-$ & $\begin{array}{l}\text { If net income for the previous period is negative and 0 } \\
\text { otherwise }\end{array}$ \\
\hline$\Delta$ REV & $\begin{array}{l}\text { Change in } \\
\text { revenues }\end{array}$ & $\begin{array}{l}\text { Difference between current years and preceding year } \\
\text { receivables }\end{array}$ \\
\hline GPPE & $\begin{array}{l}\text { Gross property } \\
\text { plant and } \\
\text { equipment }\end{array}$ & $\begin{array}{l}\text { Difference between current year and preceding year } \\
\text { revenues. }\end{array}$ \\
\hline TACCR & $\begin{array}{l}\text { Total accruals } \\
\text { Net property plant and equipment plus accumulated } \\
\text { depreciation. }\end{array}$ \\
\hline NDACCR & $\begin{array}{l}\text { Non } \\
\text { discretionary } \\
\text { accruals }\end{array}$ & $\begin{array}{l}\text { Difference between earnings before interest and tax and } \\
\text { operating cash flow }\end{array}$ \\
\hline
\end{tabular}




\section{Chapter Five}

\section{Analysis of the Results}

5.1 Introduction

5.2 Univariate analysis

5.3 Discretionary accruals

5.4 Test of the research questions

\subsection{Robustness tests}

5.5.1 Using cross-sectional Jones (1991) model

\subsubsection{Deleting smaller countries}

\subsection{Summary}




\subsection{Introduction}

This chapter presents the results of the data analysis from the research method described in chapter four. Research questions one to thirteen are tested and conclusions are drawn. These research questions test the impact of macro governance attributes (research questions one to six) and micro governance attributes (research questions seven to thirteen) with earnings management.

When testing the research questions with governance attributes the analysis proceeds in three stages. First, the relationship between the macro governance variables and earnings management is tested. The second stage assesses the relationship between micro governance variables and earnings management. Finally, the third stage of the analysis examines the joint effect of macro and micro governance variables on earnings management. The chapter proceeds as follows: Section 5.2 presents descriptive statistics and correlation coefficients. Section 5.3 describes the development of the variables for discretionary accruals. Section 5.4 discusses testing of the research questions and, Section 5.5 set out the robustness checks. Section 5.6 provides a summary of the chapter.

\subsection{Univariate analysis}

The number of firm-year observations for each of the 63 countries is reported in Table 5-1 for analyses in the study. Three countries have from 90 to 100 firm year observations, 34 countries have from 100 to 1000 firm-year observations, and 26 countries have more than 1000 firm-year observations.

\section{[Insert Table 5-1, Panel A, See Appendix-A]}


The univariate information regarding both earnings management and macro and micro level governance is presented in Table 5-1, panels B, C and D.

\section{[Insert Table 5-1, Panels B and C, See Appendix-A]}

The mean of ownership concentration is 26 percent. The ownership concentration derived in this study is comparable to that reported in previous studies reported by (i) Farooque et al. (2007) showing that Bangladesh institution owing 18 percent of the shares of listed companies, and (ii) Peasnell et al. (2005) (UK listed companies) of 21.6 percent. The proportion of outside directors on board of 75.28 percent is comparable with that reported in Lee et al. (2007) of 68 percent but is strongly dissimilar from that reported in Peasnell et al. (2005) of 43 percent. Table 51, panel C, shows that 54 percent of the sample firms employ Big 4 audit firms. This result is consistent with Hope et al. (2008), 68 percent; Karim and van Zijl (2008), 33 percent; Habib (2007) and Habib and Islam (2007), 30\%. The mean board size of 8.54 is consistent with prior studies. Firm size, as expressed by the natural log of total assets, shows considerable variation with a mean of 5.09 but standard deviation of .8753. The average debt-equity ratio is $46.62 \%$, Return on equity 6.40 percent and capital intensity ratio 33.70, and Cash flow from operations 3.46 percent. These values are consistent with previous studies such as Francis and Wang (2008) and Hope et al. (2008).

\section{[Insert Table 5-1, Panel D, See Appendix-A]}

Table 5-1, panel D, shows the correlation among the seventeen variables. Not surprisingly the correlations are relatively high. However, there is no case with a variance inflation factor greater than 5 , and thus collinearity is not a problem in this study. 


\section{[Insert Table 5-2, See Appendix-A]}

Table 5-2, shows that the mean (median) measure of discretionary accruals (DACCR) in this study is $-.1674(-.1655)$. The $25^{\text {th }}$ percentile value of discretionary accruals is -.2756 , and the $75^{\text {th }}$ percentile value is -.0451 . Taking into account the fact that 81 percent of the sampled companies had negative DACCR while the other 19 percent of the companies had positive DACCR, this result seems to suggest that managers within the sample engaged in larger decreasing DACCR compared to income increasing DACCR in the choice of accounting policies. This finding lends support to conjectures reported in Watts and Zimmerman (1986) that, if the target is based on some definition of income from current operations (above the line), earnings management strategies are expected to dump losses as nonrecurring items (below the line).

\subsection{Discretionary accruals}

In order to estimate discretionary accruals, it is first necessary to calculate total accruals. As discussed in chapter 4 , total accruals are calculated as the difference between earnings before extraordinary items and cash flows from operations (Equation ix). The modified Jones (Dechow et al. 1995) model, represented by Equation (vi), is estimated by pooled ordinary least squares (OLS) regression and the resulting equation is then used in equation (vii) to calculate discretionary accruals as the difference between actual and expected total accruals for each firm.

The calculation of total accruals covers 156,906 firm year observations over ten financial years. Table 5-3 presents the estimated coefficients of the total accruals model. 
Table 5-3: Estimation of the parameters of total accruals model for the full sample.

\begin{tabular}{|c|c|c|c|}
\hline \multicolumn{4}{|c|}{$\mathbf{T A}_{\mathrm{it}} / \mathrm{A}_{\mathrm{it}-1}=\beta_{0}\left(1 / \mathrm{A}_{\mathrm{it}-1}\right)+\beta_{1 \mathrm{it}}\left(\Delta \mathrm{REV}_{\mathrm{it}}-\Delta \mathrm{REC}_{\mathrm{it}} / \mathrm{A}_{\mathrm{it}-1}\right)+\boldsymbol{\beta}_{2}\left(\mathrm{PPE}_{\mathrm{it}} / \mathrm{A}_{\mathrm{it}-1}\right)+\varepsilon$} \\
\hline Adj. $\mathbf{R}^{2}$ & $\begin{array}{l}\text { Intercept } \\
\text { Estimate } \\
\text { (p value) }\end{array}$ & $\begin{array}{c}\Delta \mathrm{REV}-\Delta \mathrm{REC} \\
\text { Estimate } \\
\text { ( } \mathrm{p} \text { value })\end{array}$ & $\begin{array}{c}\text { PPE } \\
\text { Estimate } \\
\text { (p value) }\end{array}$ \\
\hline .656 & $\begin{array}{c}.051 \\
(.<01)\end{array}$ & $\begin{array}{c}.079 \\
(.<01)\end{array}$ & $\begin{array}{l}-.201 \\
(.<01) \\
\end{array}$ \\
\hline \multicolumn{4}{|c|}{$\begin{array}{l}\text { where } \\
T_{\text {it }} \text { is total accruals. } \\
\triangle \mathrm{REV}_{\text {it }}-\triangle \mathrm{REC}_{\mathrm{it}} \text { is the difference between change in revenue and change in receivables of firm } \mathrm{i} \text {, for the } \\
\text { period }{ }_{\mathrm{t}-1 \text { to }} \text {. } \\
\text { PPE }_{\text {it }} \text { is gross property, plant, and equipment of firm of firm } \mathrm{i} \text {, for the period }\end{array}$} \\
\hline
\end{tabular}

The model is significant at the $1 \%$ level. The modified Jones (Dechow et al. 1995) model has an explanatory power of $65.6 \%$. It allows for the estimation of discretionary accruals through deducting expected total accruals from actual total accruals (Equation vii).

Tests of earnings management should first identify the managerial incentives for earnings management and then examine the sign and magnitude of DACCR. For example, if it is hypothesized that managers manage earnings upward to avoid debt covenant violation, then for firm observation that approach debt covenant violation, it is expected that DACCR should be positive and significantly different from zero after controlling for other factors that are expected to affect DACCR values.

\subsection{Test of the research questions}

\subsubsection{Test results for research question one: Enforcement}

Research question one relates macro governance variable enforcement to the magnitude of discretionary accruals. Table 5-1, panel B, appendix A, shows the country level enforcement scores across countries. In the case of enforcement 
variable judicial independence, Germany, Finland, Australia, Netherlands, Switzerland and the United Kingdom have the strong judicial independence, while Venezuela, Argentina, Peru, Russia and Indonesia have the weakest judicial independence.

The second enforcement variable, enforcement of securities law shows that Sweden, Australia, Hong Kong, South Africa have the most transparent, effective and independent from undue influence form of enforcement, whereas China, Russia, Saudi Arabia, Egypt and Pakistan have the weakest enforcement of securities laws that is not transparent, ineffective and subject to undue influence from industry and government.

The third enforcement variable, protection of minority shareholders rights shows that Sweden, Germany, United Kingdom, Finland and Austria have the strongest protection of minority shareholders interest. On the other hand, Russia, Argentina, China, Venezuela and Italy have the weakest protection of minority shareholders interest that is minority shareholders interest is not protected by law. Next, enforcement of accounting and auditing standard in a country level shows that Germany, Sweden, United Kingdom, Australia and Austria have extremely strong enforcement for financial reporting and auditing standards for company financial performance, while China, Vietnam, Russia, Argentina, Venezuela and Nigeria have extremely weak accounting and auditing standards enforcements. For the enforcement variable rule of law, Norway, Finland, Denmark, Switzerland, New Zealand and Luxemburg have the highest scorers, while Nigeria, Venezuela, Russia, Paraguay, Colombia and Indonesia have the lowest scores. Finally, the enforcement variable press freedom shows that Netherlands, New Zealand, Denmark, Finland, 
Sweden and Switzerland have the highest scores, while China, Vietnam, Saudi Arabia, Russia, and Pakistan have the lowest scores. Table 5-4 (i) to 5-4 (vi), display the pooled and year wise regression results for the association between enforcement and discretionary accruals. 


\section{Table 5-4 (i)}

Regression analysis of discretionary accruals with judicial independence

\section{(Dependent variable is signed discretionary accruals: DACCR)}

$\mathbf{D A C C R}_{\text {it }}=\beta_{0}+\boldsymbol{\beta}_{\mathbf{1}} \mathbf{J U D}+\beta_{2} \mathrm{SIZE}_{\mathrm{it}}+\beta_{3} \mathrm{LEV}_{\text {it }}+\beta_{4} \mathrm{GWTH}_{\mathrm{it}}+\beta_{5} \mathrm{CFO}_{\mathrm{it}}+\beta_{6} \mathrm{CAP}_{\mathrm{it}}+\beta_{7} \mathrm{LOSS}_{\text {it }}+$ fixed effects

\begin{tabular}{|c|c|c|c|c|c|c|c|c|c|c|}
\hline $\begin{array}{l}\text { Independent } \\
\text { variables }\end{array}$ & $\begin{array}{c}\text { Pooled } \\
\text { Estimate } \\
\text { (p-value) }\end{array}$ & $\begin{array}{c}1999 \\
\text { Estimate } \\
\text { (p-value) }\end{array}$ & $\begin{array}{c}\mathbf{2 0 0 0} \\
\text { Estimate } \\
\text { (p-value) }\end{array}$ & $\begin{array}{c}\mathbf{2 0 0 1} \\
\text { Estimate } \\
\text { (p-value) }\end{array}$ & $\begin{array}{c}2002 \\
\text { Estimate } \\
\text { (p-value) }\end{array}$ & $\begin{array}{c}\mathbf{2 0 0 3} \\
\text { Estimate } \\
\text { (p-value) }\end{array}$ & $\begin{array}{c}\mathbf{2 0 0 4} \\
\text { Estimate } \\
\text { (p-value) }\end{array}$ & $\begin{array}{c}\mathbf{2 0 0 5} \\
\text { Estimate } \\
\text { (p-value) }\end{array}$ & $\begin{array}{c}\mathbf{2 0 0 6} \\
\text { Estimate } \\
\text { (p-value) }\end{array}$ & $\begin{array}{c}\mathbf{2 0 0 7} \\
\text { Estimate } \\
\text { (p-value) }\end{array}$ \\
\hline Constant & $\begin{array}{c}-.285 \\
(<0.01)\end{array}$ & $\begin{array}{l}-.226 \\
(<0.01)\end{array}$ & $\begin{array}{c}-.172 \\
(<0.01)\end{array}$ & $\begin{array}{l}-.293 \\
(<0.01)\end{array}$ & $\begin{array}{l}-.326 \\
(<0.01)\end{array}$ & $\begin{array}{c}-.282 \\
(<0.01)\end{array}$ & $\begin{array}{l}-.274 \\
(<0.01)\end{array}$ & $\begin{array}{c}-.264 \\
(<0.01)\end{array}$ & $\begin{array}{l}-.276 \\
(<0.01)\end{array}$ & $\begin{array}{c}-.300 \\
(<0.01)\end{array}$ \\
\hline JUD & $\begin{array}{c}-.008 \\
(<0.01)\end{array}$ & $\begin{array}{c}-.004 \\
(.039)\end{array}$ & $\begin{array}{l}-.005 \\
(.023)\end{array}$ & $\begin{array}{c}-.015 \\
(<0.01)\end{array}$ & $\begin{array}{c}-.010 \\
(<0.01)\end{array}$ & $\begin{array}{c}-.011 \\
(<0.01)\end{array}$ & $\begin{array}{c}-.006 \\
(<0.01)\end{array}$ & $\begin{array}{c}-.005 \\
(<0.01)\end{array}$ & $\begin{array}{c}-.008 \\
(<0.01)\end{array}$ & $\begin{array}{c}-.011 \\
(<0.01)\end{array}$ \\
\hline SIZE & $\begin{array}{c}.011 \\
(<0.01)\end{array}$ & $\begin{array}{l}-.009 \\
(.002)\end{array}$ & $\begin{array}{l}.004 \\
(.144)\end{array}$ & $\begin{array}{c}.020 \\
(<0.01)\end{array}$ & $\begin{array}{c}.023 \\
(<0.01)\end{array}$ & $\begin{array}{c}.013 \\
(<0.01)\end{array}$ & $\begin{array}{c}.006 \\
(<0.01)\end{array}$ & $\begin{array}{c}.007 \\
(<0.01)\end{array}$ & $\begin{array}{c}.009 \\
(<0.01)\end{array}$ & $\begin{array}{c}.017 \\
(<0.01)\end{array}$ \\
\hline LEV & $\begin{array}{c}.020 \\
(<0.01)\end{array}$ & $\begin{array}{c}-.024 \\
(<0.01)\end{array}$ & $\begin{array}{c}.028 \\
(<0.01)\end{array}$ & $\begin{array}{c}.026 \\
(<0.01)\end{array}$ & $\begin{array}{c}.024 \\
(<0.01)\end{array}$ & $\begin{array}{c}.016 \\
(<0.01)\end{array}$ & $\begin{array}{c}.014 \\
(<0.01)\end{array}$ & $\begin{array}{c}.016 \\
(<0.01)\end{array}$ & $\begin{array}{c}.018 \\
(<0.01)\end{array}$ & $\begin{array}{c}.016 \\
(<0.01)\end{array}$ \\
\hline GWTH & $\begin{array}{c}.053 \\
(<0.01)\end{array}$ & $\begin{array}{c}.050 \\
(<0.01)\end{array}$ & $\begin{array}{c}.041 \\
(<0.01)\end{array}$ & $\begin{array}{c}.049 \\
(<0.01)\end{array}$ & $\begin{array}{c}.042 \\
(<0.01)\end{array}$ & $\begin{array}{c}.037 \\
(<0.01)\end{array}$ & $\begin{array}{c}.053 \\
(<0.01)\end{array}$ & $\begin{array}{c}.056 \\
(<0.01)\end{array}$ & $\begin{array}{c}.070 \\
(<0.01)\end{array}$ & $\begin{array}{c}.065 \\
(<0.01)\end{array}$ \\
\hline $\mathrm{CFO}$ & $\begin{array}{c}-.390 \\
(<0.01)\end{array}$ & $\begin{array}{l}-.296 \\
(<0.01)\end{array}$ & $\begin{array}{c}-.211 \\
(<0.01)\end{array}$ & $\begin{array}{l}-.334 \\
(<0.01)\end{array}$ & $\begin{array}{c}-.419 \\
(<0.01)\end{array}$ & $\begin{array}{l}-.430 \\
(<0.01)\end{array}$ & $\begin{array}{c}-.449 \\
(<0.01)\end{array}$ & $\begin{array}{c}-.464 \\
(<0.01)\end{array}$ & $\begin{array}{c}-.428 \\
(<0.01)\end{array}$ & $\begin{array}{c}-.466 \\
(<0.01)\end{array}$ \\
\hline CAP & $\begin{array}{c}.461 \\
(<0.01)\end{array}$ & $\begin{array}{c}.458 \\
(<0.01)\end{array}$ & $\begin{array}{c}.408 \\
(<0.01)\end{array}$ & $\begin{array}{c}.400 \\
(<0.01)\end{array}$ & $\begin{array}{c}.408 \\
(<0.01)\end{array}$ & $\begin{array}{c}.467 \\
(<0.01)\end{array}$ & $\begin{array}{c}.481 \\
(<0.01)\end{array}$ & $\begin{array}{c}.465 \\
(<0.01)\end{array}$ & $\begin{array}{c}.488 \\
(<0.01)\end{array}$ & $\begin{array}{c}.494 \\
(<0.01)\end{array}$ \\
\hline LOSS & $\begin{array}{c}-.141 \\
(<0.01)\end{array}$ & $\begin{array}{l}-.155 \\
(<0.01)\end{array}$ & $\begin{array}{l}-.167 \\
(<0.01)\end{array}$ & $\begin{array}{l}-.136 \\
(<0.01)\end{array}$ & $\begin{array}{c}-.136 \\
(<0.01)\end{array}$ & $\begin{array}{c}-.122 \\
(<0.01)\end{array}$ & $\begin{array}{c}-.123 \\
(<0.01)\end{array}$ & $\begin{array}{c}-.133 \\
(<0.01)\end{array}$ & $\begin{array}{l}-.138 \\
(<0.01)\end{array}$ & $\begin{array}{c}-.146 \\
(<0.01)\end{array}$ \\
\hline fixed effects & included & included & included & included & included & included & included & included & included & included \\
\hline Adj. $R^{2}$ & .416 & .354 & .322 & .373 & .412 & .469 & .471 & .442 & .449 & .459 \\
\hline $\mathbf{N}$ & 156,906 & 156,906 & 156,906 & 156,906 & 156,906 & 156,906 & 156,906 & 156,906 & 156,906 & 156,906 \\
\hline
\end{tabular}

Note: Coefficient p-values applied two-tail and based on asymptotic Z-statistic robust to hetroscedasticity and country clustering effects using the method in Rogers (1993). For clarity in presentation the coefficients on year and country dummies have not been reported.

DACCR $=$ signed discretionary accruals. JUD $=$ judicial independence $($ WEF 2008). SIZE $=$ natural logarithm of total assets in $\$$ thousands for firm i in year t. $\mathbf{L E V}=$ total long-term debt/equity for firm $\mathrm{i}$ in year t. GWTH = sales growth rate, defined as the sales in year t minus sales in t-1 and scaled by sales in year t. CFO $=$ operating cash flows for firm $\mathrm{i}$ in year $\mathrm{t}$ scaled by lagged total assets. $\mathbf{C A P}=$ non-current (fixed) assets in year $\mathrm{t} /$ Total assets in year $\mathrm{t}$. LOSS $=$ indicator variable with the value of 1 if firm i reports negative net income in the previous year and 0 otherwise. 
Table 5-4 (ii)

Regression analysis of discretionary accruals with enforcement of securities laws

(Dependent variable is signed discretionary accruals: DACCR)

$\mathbf{D A C C R}_{i \mathrm{t}}=\beta_{0}+\boldsymbol{\beta}_{1} \mathbf{S E C}+\beta_{2} \mathrm{SIZE}_{\mathrm{it}}+\beta_{3} \mathrm{LEV}_{\mathrm{it}}+\beta_{4} \mathrm{GWTH}_{\mathrm{it}}+\beta_{5} \mathrm{CFO}_{\mathrm{it}}+\beta_{6} \mathrm{CAP}_{\mathrm{it}}+\beta_{7} \mathrm{LOSS}_{\mathrm{it}}+$ fixed effects

\begin{tabular}{|c|c|c|c|c|c|c|c|c|c|c|}
\hline $\begin{array}{l}\text { Independent } \\
\text { variables }\end{array}$ & $\begin{array}{c}\text { Pooled } \\
\text { Estimate } \\
\text { (p-value) }\end{array}$ & $\begin{array}{c}1999 \\
\text { Estimate } \\
\text { (p-value) }\end{array}$ & $\begin{array}{c}\mathbf{2 0 0 0} \\
\text { Estimate } \\
\text { (p-value) }\end{array}$ & $\begin{array}{c}\mathbf{2 0 0 1} \\
\text { Estimate } \\
\text { (p-value) }\end{array}$ & $\begin{array}{c}2002 \\
\text { Estimate } \\
\text { (p-value) }\end{array}$ & $\begin{array}{c}\mathbf{2 0 0 3} \\
\text { Estimate } \\
\text { (p-value) }\end{array}$ & $\begin{array}{c}\mathbf{2 0 0 4} \\
\text { Estimate } \\
\text { (p-value) }\end{array}$ & $\begin{array}{c}\mathbf{2 0 0 5} \\
\text { Estimate } \\
\text { (p-value) }\end{array}$ & $\begin{array}{c}\mathbf{2 0 0 6} \\
\text { Estimate } \\
\text { (p-value) }\end{array}$ & $\begin{array}{c}\mathbf{2 0 0 7} \\
\text { Estimate } \\
\text { (p-value) }\end{array}$ \\
\hline Constant & $\begin{array}{c}-.304 \\
(<0.01)\end{array}$ & $\begin{array}{l}-.196 \\
(<0.01)\end{array}$ & $\begin{array}{l}-.173 \\
(<0.01)\end{array}$ & $\begin{array}{l}-.342 \\
(<0.01)\end{array}$ & $\begin{array}{l}-.356 \\
(<0.01)\end{array}$ & $\begin{array}{l}-.330 \\
(<0.01)\end{array}$ & $\begin{array}{l}-.310 \\
(<0.01)\end{array}$ & $\begin{array}{c}-.291 \\
(<0.01)\end{array}$ & $\begin{array}{l}-.297 \\
(<0.01)\end{array}$ & $\begin{array}{c}-.311 \\
(<0.01)\end{array}$ \\
\hline SEC & $\begin{array}{c}-.004 \\
(<0.01)\end{array}$ & $\begin{array}{c}-.019 \\
(<0.01)\end{array}$ & $\begin{array}{l}-.010 \\
(.017)\end{array}$ & $\begin{array}{c}-.006 \\
(.325)\end{array}$ & $\begin{array}{l}-.004 \\
(.319)\end{array}$ & $\begin{array}{c}-.002 \\
(<0.01)\end{array}$ & $\begin{array}{c}.001 \\
(.432)\end{array}$ & $\begin{array}{l}-.0004 \\
(.980)\end{array}$ & $\begin{array}{l}-.004 \\
(.018)\end{array}$ & $\begin{array}{c}-.008 \\
(<0.01)\end{array}$ \\
\hline SIZE & $\begin{array}{c}.011 \\
(<0.01)\end{array}$ & $\begin{array}{l}.009 \\
(.003)\end{array}$ & $\begin{array}{l}.004 \\
(.248)\end{array}$ & $\begin{array}{l}.021 \\
(<0.01)\end{array}$ & $\begin{array}{c}.023 \\
(<0.01)\end{array}$ & $\begin{array}{c}.013 \\
(<0.01)\end{array}$ & $\begin{array}{c}.006 \\
(<0.01)\end{array}$ & $\begin{array}{l}.007 \\
(<0.01)\end{array}$ & $\begin{array}{c}.009 \\
(<0.01)\end{array}$ & $\begin{array}{c}.017 \\
(<0.01)\end{array}$ \\
\hline LEV & $\begin{array}{c}.019 \\
(<0.01)\end{array}$ & $\begin{array}{c}.024 \\
(<0.01)\end{array}$ & $\begin{array}{c}.028 \\
(<0.01)\end{array}$ & $\begin{array}{c}.026 \\
(<0.01)\end{array}$ & $\begin{array}{c}.024 \\
(<0.01)\end{array}$ & $\begin{array}{c}.015 \\
(<0.01)\end{array}$ & $\begin{array}{c}.014 \\
(<0.01)\end{array}$ & $\begin{array}{c}.016 \\
(<0.01)\end{array}$ & $\begin{array}{c}.017 \\
(<0.01)\end{array}$ & $\begin{array}{c}.016 \\
(<0.01)\end{array}$ \\
\hline GWTH & $\begin{array}{c}.053 \\
(<0.01)\end{array}$ & $\begin{array}{c}.049 \\
(<0.01)\end{array}$ & $\begin{array}{c}.040 \\
(<0.01)\end{array}$ & $\begin{array}{c}.050 \\
(<0.01)\end{array}$ & $\begin{array}{c}.042 \\
(<0.01)\end{array}$ & $\begin{array}{c}.038 \\
(<0.01)\end{array}$ & $\begin{array}{c}.053 \\
(<0.01)\end{array}$ & $\begin{array}{c}.056 \\
(<0.01)\end{array}$ & $\begin{array}{c}.071 \\
(<0.01)\end{array}$ & $\begin{array}{c}.066 \\
(<0.01)\end{array}$ \\
\hline $\mathrm{CFO}$ & $\begin{array}{l}-.391 \\
(<0.01)\end{array}$ & $\begin{array}{c}-.291 \\
(<0.01)\end{array}$ & $\begin{array}{l}-.202 \\
(<0.01)\end{array}$ & $\begin{array}{l}-.335 \\
(<0.01)\end{array}$ & $\begin{array}{c}-.419 \\
(<0.01)\end{array}$ & $\begin{array}{l}-.433 \\
(<0.01)\end{array}$ & $\begin{array}{l}-.451 \\
(<0.01)\end{array}$ & $\begin{array}{l}-.465 \\
(<0.01)\end{array}$ & $\begin{array}{l}-.429 \\
(<0.01)\end{array}$ & $\begin{array}{l}-.467 \\
(<0.01)\end{array}$ \\
\hline CAP & $\begin{array}{c}.464 \\
(<0.01)\end{array}$ & $\begin{array}{c}.455 \\
(<0.01)\end{array}$ & $\begin{array}{c}.405 \\
(<0.01)\end{array}$ & $\begin{array}{c}.403 \\
(<0.01)\end{array}$ & $\begin{array}{c}.410 \\
(<0.01)\end{array}$ & $\begin{array}{c}.471 \\
(<0.01)\end{array}$ & $\begin{array}{c}.484 \\
(<0.01)\end{array}$ & $\begin{array}{c}.468 \\
(<0.01)\end{array}$ & $\begin{array}{c}.491 \\
(<0.01)\end{array}$ & $\begin{array}{c}.497 \\
(<0.01)\end{array}$ \\
\hline LOSS & $\begin{array}{c}-.141 \\
(<0.01)\end{array}$ & $\begin{array}{l}-.158 \\
(<0.01)\end{array}$ & $\begin{array}{l}-.170 \\
(<0.01)\end{array}$ & $\begin{array}{l}-.137 \\
(<0.01)\end{array}$ & $\begin{array}{c}-.135 \\
(<0.01)\end{array}$ & $\begin{array}{c}-.123 \\
(<0.01)\end{array}$ & $\begin{array}{c}-.124 \\
(<0.01)\end{array}$ & $\begin{array}{l}-.134 \\
(<0.01)\end{array}$ & $\begin{array}{l}-.138 \\
(<0.01)\end{array}$ & $\begin{array}{c}-.147 \\
(<0.01)\end{array}$ \\
\hline fixed effects & included & included & included & included & included & included & included & included & included & included \\
\hline Adj. $R^{2}$ & .415 & .354 & .313 & .372 & .411 & .466 & .471 & .442 & .448 & .458 \\
\hline $\mathbf{N}$ & 156,906 & 156,906 & 156,906 & 156,906 & 156,906 & 156,906 & 156,906 & 156,906 & 156,906 & 156,906 \\
\hline
\end{tabular}

Note: Coefficient p-values applied two-tail and based on asymptotic Z-statistic robust to hetroscedasticity and country clustering effects using the method in Rogers (1993). For clarity in presentation the coefficients on year and country dummies have not been reported.

DACCR = signed discretionary accruals. SEC $=$ enforcement of securities laws (WEF 2008). SIZE $=$ natural logarithm of total assets in $\$$ thousands for firm i in year $\mathrm{t} . \mathbf{L E V}=$ total long-term debt/equity for firm $\mathrm{i}$ in year $\mathrm{t}$. $\mathbf{G W T H}=$ sales growth rate, defined as the sales in year $\mathrm{t}$ minus sales in $\mathrm{t}-1$ and scaled by sales in year $\mathrm{t}$. CFO $=$ operating cash flows for firm $\mathrm{i}$ in year $\mathrm{t}$ scaled by lagged total assets. CAP $=$ non-current (fixed) assets in year $\mathrm{t} /$ Total assets in year $\mathrm{t}$. LOSS $=$ indicator variable with the value of 1 if firm i reports negative net income in the previous year and 0 otherwise. 
Table 5-4 (iii)

Regression analysis of discretionary accruals with protection of minority shareholders interests

(Dependent variable is signed discretionary accruals: DACCR)

$\mathbf{D A C C R}_{\mathrm{it}}=\beta_{0}+\boldsymbol{\beta}_{1} \mathrm{MIN}+\beta_{2} \mathrm{SIZE}_{\mathrm{it}}+\beta_{3} \mathrm{LEV}_{\mathrm{it}}+\beta_{4} \mathrm{GWTH}_{\mathrm{it}}+\beta_{5} \mathrm{CFO}_{\mathrm{it}}+\beta_{6} \mathrm{CAP}_{\mathrm{it}}+\beta_{7} \mathrm{LOSS}_{\mathrm{it}}+$ fixed effects

\begin{tabular}{|c|c|c|c|c|c|c|c|c|c|c|}
\hline $\begin{array}{l}\text { Independent } \\
\text { variables }\end{array}$ & $\begin{array}{c}\text { Pooled } \\
\text { Estimate } \\
\text { (p-value) }\end{array}$ & $\begin{array}{c}1999 \\
\text { Estimate } \\
\text { (p-value) }\end{array}$ & $\begin{array}{c}\mathbf{2 0 0 0} \\
\text { Estimate } \\
\text { (p-value) }\end{array}$ & $\begin{array}{c}\mathbf{2 0 0 1} \\
\text { Estimate } \\
\text { (p-value) }\end{array}$ & $\begin{array}{c}\mathbf{2 0 0 2} \\
\text { Estimate } \\
\text { (p-value) }\end{array}$ & $\begin{array}{c}\mathbf{2 0 0 3} \\
\text { Estimate } \\
\text { (p-value) }\end{array}$ & $\begin{array}{c}\mathbf{2 0 0 4} \\
\text { Estimate } \\
\text { (p-value) }\end{array}$ & $\begin{array}{c}\mathbf{2 0 0 5} \\
\text { Estimate } \\
\text { (p-value) }\end{array}$ & $\begin{array}{c}\mathbf{2 0 0 6} \\
\text { Estimate } \\
\text { (p-value) }\end{array}$ & $\begin{array}{c}\mathbf{2 0 0 7} \\
\text { Estimate } \\
\text { (p-value) }\end{array}$ \\
\hline Constant & $\begin{array}{c}-.253 \\
(<0.01)\end{array}$ & $\begin{array}{l}-.239 \\
(<0.01)\end{array}$ & $\begin{array}{c}-.173 \\
(<0.01)\end{array}$ & $\begin{array}{l}-.100 \\
(.002)\end{array}$ & $\begin{array}{l}-.256 \\
(<0.01)\end{array}$ & $\begin{array}{c}-.282 \\
(<0.01)\end{array}$ & $\begin{array}{c}-.290 \\
(<0.01)\end{array}$ & $\begin{array}{c}-.262 \\
(<0.01)\end{array}$ & $\begin{array}{l}-.258 \\
(<0.01)\end{array}$ & $\begin{array}{l}-.277 \\
(<0.01)\end{array}$ \\
\hline MIN & $\begin{array}{c}-.013 \\
(<0.01)\end{array}$ & $\begin{array}{l}-.015 \\
(.041)\end{array}$ & $\begin{array}{l}-.010 \\
(.017)\end{array}$ & $\begin{array}{c}-.050 \\
(<0.01)\end{array}$ & $\begin{array}{c}-.023 \\
(<0.01)\end{array}$ & $\begin{array}{c}-.011 \\
(<0.01)\end{array}$ & $\begin{array}{l}-.002 \\
(.219)\end{array}$ & $\begin{array}{l}-.005 \\
(.005)\end{array}$ & $\begin{array}{c}-.011 \\
(<0.01)\end{array}$ & $\begin{array}{c}-.014 \\
(<0.01)\end{array}$ \\
\hline SIZE & $\begin{array}{c}.011 \\
(<0.01)\end{array}$ & $\begin{array}{l}.008 \\
(.004)\end{array}$ & $\begin{array}{l}.004 \\
(.248)\end{array}$ & $\begin{array}{c}.019 \\
(<0.01)\end{array}$ & $\begin{array}{c}.023 \\
(<0.01)\end{array}$ & $\begin{array}{c}.012 \\
(<0.01)\end{array}$ & $\begin{array}{c}.006 \\
(<0.01)\end{array}$ & $\begin{array}{l}.006 \\
(<0.01)\end{array}$ & $\begin{array}{c}.009 \\
(<0.01)\end{array}$ & $\begin{array}{c}.017 \\
(<0.01)\end{array}$ \\
\hline LEV & $\begin{array}{c}.020 \\
(<0.01)\end{array}$ & $\begin{array}{c}.024 \\
(<0.01)\end{array}$ & $\begin{array}{c}.028 \\
(<0.01)\end{array}$ & $\begin{array}{c}.026 \\
(<0.01)\end{array}$ & $\begin{array}{c}.024 \\
(<0.01)\end{array}$ & $\begin{array}{c}.016 \\
(<0.01)\end{array}$ & $\begin{array}{c}.014 \\
(<0.01)\end{array}$ & $\begin{array}{l}.016 \\
(<0.01)\end{array}$ & $\begin{array}{c}.018 \\
(<0.01)\end{array}$ & $\begin{array}{c}.017 \\
(<0.01)\end{array}$ \\
\hline GWTH & $\begin{array}{c}.053 \\
(<0.01)\end{array}$ & $\begin{array}{c}.050 \\
(<0.01)\end{array}$ & $\begin{array}{c}.040 \\
(<0.01)\end{array}$ & $\begin{array}{c}.049 \\
(<0.01)\end{array}$ & $\begin{array}{c}.041 \\
(<0.01)\end{array}$ & $\begin{array}{c}.038 \\
(<0.01)\end{array}$ & $\begin{array}{l}.053 \\
(<0.01)\end{array}$ & $\begin{array}{l}.056 \\
(<0.01)\end{array}$ & $\begin{array}{c}.071 \\
(<0.01)\end{array}$ & $\begin{array}{c}.066 \\
(<0.01)\end{array}$ \\
\hline CFO & $\begin{array}{c}-.390 \\
(<0.01)\end{array}$ & $\begin{array}{c}-.295 \\
(<0.01)\end{array}$ & $\begin{array}{c}-.202 \\
(<0.01)\end{array}$ & $\begin{array}{c}-.329 \\
(<0.01)\end{array}$ & $\begin{array}{c}-.419 \\
(<0.01)\end{array}$ & $\begin{array}{c}-.431 \\
(<0.01)\end{array}$ & $\begin{array}{c}-.450 \\
(<0.01)\end{array}$ & $\begin{array}{c}-.464 \\
(<0.01)\end{array}$ & $\begin{array}{c}-.428 \\
(<0.01)\end{array}$ & $\begin{array}{c}-.466 \\
(<0.01)\end{array}$ \\
\hline CAP & $\begin{array}{c}.461 \\
(<0.01)\end{array}$ & $\begin{array}{c}.473 \\
(<0.01)\end{array}$ & $\begin{array}{c}.405 \\
(<0.01)\end{array}$ & $\begin{array}{c}.396 \\
(<0.01)\end{array}$ & $\begin{array}{c}.407 \\
(<0.01)\end{array}$ & $\begin{array}{c}.469 \\
(<0.01)\end{array}$ & $\begin{array}{c}.483 \\
(<0.01)\end{array}$ & $\begin{array}{l}.466 \\
(<0.01)\end{array}$ & $\begin{array}{c}.489 \\
(<0.01)\end{array}$ & $\begin{array}{c}.495 \\
(<0.01)\end{array}$ \\
\hline LOSS & $\begin{array}{c}-.139 \\
(<0.01)\end{array}$ & $\begin{array}{c}-.160 \\
(<0.01)\end{array}$ & $\begin{array}{l}-.170 \\
(<0.01)\end{array}$ & $\begin{array}{l}-.132 \\
(<0.01)\end{array}$ & $\begin{array}{c}-.134 \\
(<0.01)\end{array}$ & $\begin{array}{c}-.121 \\
(<0.01)\end{array}$ & $\begin{array}{c}-.123 \\
(<0.01)\end{array}$ & $\begin{array}{l}-.133 \\
(<0.01)\end{array}$ & $\begin{array}{c}-.137 \\
(<0.01)\end{array}$ & $\begin{array}{c}-.145 \\
(<0.01)\end{array}$ \\
\hline fixed effects & included & included & included & included & included & included & included & included & included & included \\
\hline Adj. $\mathbf{R}^{2}$ & .416 & .347 & .311 & .379 & .413 & .467 & .471 & .442 & .449 & .459 \\
\hline $\mathbf{N}$ & 156,906 & 156,906 & 156,906 & 156,906 & 156,906 & 156,906 & 156,906 & 156,906 & 156,906 & 156,906 \\
\hline
\end{tabular}

Note: Coefficient p-values applied two-tail and based on asymptotic Z-statistic robust to hetroscedasticity and country clustering effects using the method in Rogers (1993).For clarity in presentation the coefficients on year and country dummies have not been reported.

DACCR = signed discretionary accruals. MIN = protection of minority shareholders interest (WEF 2008). SIZE $=$ natural logarithm of total assets in $\$$ thousands for firm i in year t. $\mathbf{L E V}=$ total long-term debt/equity for firm i in year t. GWTH = sales growth rate, defined as the sales in year $\mathrm{t}$ minus sales in $\mathrm{t}-1$ and scaled by sales in year t. CFO = operating cash flows for firm i in year t scaled by lagged total assets. CAP = non-current (fixed) assets in year $\mathrm{t} / \mathrm{Total}$ assets in year t. LOSS $=$ indicator variable with the value of 1 if firm i reports negative net income in the previous year and 0 otherwise. 
Table 5-4 (iv)

Regression analysis of discretionary accruals with enforcement of accounting and auditing standards (Dependent variable is signed discretionary accruals: DACCR)

\begin{tabular}{|c|c|c|c|c|c|c|c|c|c|c|}
\hline $\begin{array}{l}\text { Independent } \\
\text { variables }\end{array}$ & $\begin{array}{c}\text { Pooled } \\
\text { Estimate } \\
\text { (p-value) }\end{array}$ & $\begin{array}{c}1999 \\
\text { Estimate } \\
\text { (p-value) }\end{array}$ & $\begin{array}{c}\mathbf{2 0 0 0} \\
\text { Estimate } \\
\text { (p-value) }\end{array}$ & $\begin{array}{c}\mathbf{2 0 0 1} \\
\text { Estimate } \\
\text { (p-value) }\end{array}$ & $\begin{array}{c}\mathbf{2 0 0 2} \\
\text { Estimate } \\
\text { (p-value) }\end{array}$ & $\begin{array}{c}\mathbf{2 0 0 3} \\
\text { Estimate } \\
\text { (p-value) }\end{array}$ & $\begin{array}{c}\mathbf{2 0 0 4} \\
\text { Estimate } \\
\text { (p-value) }\end{array}$ & $\begin{array}{c}\mathbf{2 0 0 5} \\
\text { Estimate } \\
\text { (p-value) }\end{array}$ & $\begin{array}{c}\mathbf{2 0 0 6} \\
\text { Estimate } \\
\text { (p-value) }\end{array}$ & $\begin{array}{c}\mathbf{2 0 0 7} \\
\text { Estimate } \\
\text { (p-value) }\end{array}$ \\
\hline Constant & $\begin{array}{c}-.255 \\
(<0.01)\end{array}$ & $\begin{array}{c}-.278 \\
(<0.01)\end{array}$ & $\begin{array}{c}-.218 \\
(<0.01)\end{array}$ & $\begin{array}{l}-.123 \\
(<0.01)\end{array}$ & $\begin{array}{l}-.245 \\
(<0.01)\end{array}$ & $\begin{array}{l}-.277 \\
(<0.01)\end{array}$ & $\begin{array}{c}-.282 \\
(<0.01)\end{array}$ & $\begin{array}{l}-.261 \\
(<0.01)\end{array}$ & $\begin{array}{c}-.267 \\
(<0.01)\end{array}$ & $\begin{array}{c}-.278 \\
(<0.01)\end{array}$ \\
\hline $\mathrm{ACC}$ & $\begin{array}{c}-.013 \\
(<0.01)\end{array}$ & $\begin{array}{l}-.007 \\
(.295)\end{array}$ & $\begin{array}{l}-.011 \\
(.130)\end{array}$ & $\begin{array}{l}-.043 \\
(<0.01)\end{array}$ & $\begin{array}{c}-.024 \\
(<0.01)\end{array}$ & $\begin{array}{c}-.011 \\
(<0.01)\end{array}$ & $\begin{array}{l}-.004 \\
(.041)\end{array}$ & $\begin{array}{l}-.005 \\
(.003)\end{array}$ & $\begin{array}{c}-.009 \\
(<0.01)\end{array}$ & $\begin{array}{c}-.014 \\
(<0.01)\end{array}$ \\
\hline SIZE & $\begin{array}{c}.011 \\
(<0.01)\end{array}$ & $\begin{array}{l}.008 \\
(.004)\end{array}$ & $\begin{array}{c}.003 \\
(.377)\end{array}$ & $\begin{array}{c}.019 \\
(<0.01)\end{array}$ & $\begin{array}{c}.023 \\
(<0.01)\end{array}$ & $\begin{array}{c}.012 \\
(<0.01)\end{array}$ & $\begin{array}{c}.006 \\
(<0.01)\end{array}$ & $\begin{array}{c}.006 \\
(<0.01)\end{array}$ & $\begin{array}{c}.009 \\
(<0.01)\end{array}$ & $\begin{array}{c}.017 \\
(<0.01)\end{array}$ \\
\hline LEV & $\begin{array}{c}.020 \\
(<0.01)\end{array}$ & $\begin{array}{c}.024 \\
(<0.01)\end{array}$ & $\begin{array}{c}.028 \\
(<0.01)\end{array}$ & $\begin{array}{c}.026 \\
(<0.01)\end{array}$ & $\begin{array}{c}.024 \\
(<0.01)\end{array}$ & $\begin{array}{c}.016 \\
(<0.01)\end{array}$ & $\begin{array}{c}.014 \\
(<0.01)\end{array}$ & $\begin{array}{c}.016 \\
(<0.01)\end{array}$ & $\begin{array}{c}.018 \\
(<0.01)\end{array}$ & $\begin{array}{c}.017 \\
(<0.01)\end{array}$ \\
\hline GWTH & $\begin{array}{c}.053 \\
(<0.01)\end{array}$ & $\begin{array}{c}.050 \\
(<0.01)\end{array}$ & $\begin{array}{c}.043 \\
(<0.01)\end{array}$ & $\begin{array}{c}.049 \\
(<0.01)\end{array}$ & $\begin{array}{c}.041 \\
(<0.01)\end{array}$ & $\begin{array}{c}.038 \\
(<0.01)\end{array}$ & $\begin{array}{c}.053 \\
(<0.01)\end{array}$ & $\begin{array}{c}.056 \\
(<0.01)\end{array}$ & $\begin{array}{c}.071 \\
(<0.01)\end{array}$ & $\begin{array}{c}.066 \\
(<0.01)\end{array}$ \\
\hline $\mathrm{CFO}$ & $\begin{array}{l}-.390 \\
(<0.01)\end{array}$ & $\begin{array}{l}-.295 \\
(<0.01)\end{array}$ & $\begin{array}{l}-.212 \\
(<0.01)\end{array}$ & $\begin{array}{l}-.331 \\
(<0.01)\end{array}$ & $\begin{array}{l}-.418 \\
(<0.01)\end{array}$ & $\begin{array}{l}-.430 \\
(<0.01)\end{array}$ & $\begin{array}{l}-.449 \\
(<0.01)\end{array}$ & $\begin{array}{l}-.464 \\
(<0.01)\end{array}$ & $\begin{array}{l}-.428 \\
(<0.01)\end{array}$ & $\begin{array}{l}-.465 \\
(<0.01)\end{array}$ \\
\hline CAP & $\begin{array}{l}.461 \\
(<0.01)\end{array}$ & $\begin{array}{c}.474 \\
(<0.01)\end{array}$ & $\begin{array}{c}.425 \\
(<0.01)\end{array}$ & $\begin{array}{c}.396 \\
(<0.01)\end{array}$ & $\begin{array}{c}.406 \\
(<0.01)\end{array}$ & $\begin{array}{c}.468 \\
(<0.01)\end{array}$ & $\begin{array}{c}.482 \\
(<0.01)\end{array}$ & $\begin{array}{c}.466 \\
(<0.01)\end{array}$ & $\begin{array}{c}.489 \\
(<0.01)\end{array}$ & $\begin{array}{c}.494 \\
(<0.01)\end{array}$ \\
\hline LOSS & $\begin{array}{c}-.139 \\
(<0.01)\end{array}$ & $\begin{array}{c}-.160 \\
(<0.01)\end{array}$ & $\begin{array}{c}-.175 \\
(<0.01)\end{array}$ & $\begin{array}{l}-.133 \\
(<0.01)\end{array}$ & $\begin{array}{c}-.134 \\
(<0.01)\end{array}$ & $\begin{array}{l}-.120 \\
(<0.01)\end{array}$ & $\begin{array}{c}-.123 \\
(<0.01)\end{array}$ & $\begin{array}{l}-.133 \\
(<0.01)\end{array}$ & $\begin{array}{c}-.137 \\
(<0.01)\end{array}$ & $\begin{array}{c}-.145 \\
(<0.01)\end{array}$ \\
\hline fixed effects & included & included & included & included & included & included & included & included & included & included \\
\hline Adj. $\mathbf{R}^{2}$ & .416 & .347 & .311 & .378 & .413 & .468 & .471 & .442 & .448 & .459 \\
\hline $\mathbf{N}$ & 156,906 & 156,906 & 156,906 & 156,906 & 156,906 & 156,906 & 156,906 & 156,906 & 156,906 & 156,906 \\
\hline
\end{tabular}

Note: Coefficient p-values applied two-tail and based on asymptotic Z-statistic robust to hetroscedasticity and country clustering effects using the method in Rogers (1993). For clarity in presentation the coefficients on year and country dummies have not been reported.

DACCR = signed discretionary accruals. ACC $=$ enforcement of accounting and auditing standards (WEF 2008). SIZE $=$ natural logarithm of total assets in $\$$ thousands for firm $\mathrm{i}$ in year $\mathrm{t}$. $\mathbf{L E V}=$ total long-term debt/equity for firm $\mathrm{i}$ in year $\mathrm{t}$. $\mathbf{G W T H}=$ sales growth rate, defined as the sales in year $\mathrm{t}$ minus sales in $\mathrm{t}-1$ and scaled by sales in year t. CFO = operating cash flows for firm i in year $\mathrm{t}$ scaled by lagged total assets. $\mathbf{C A P}=$ non-current (fixed) assets in year $\mathrm{t} /$ Total assets in year t. LOSS = indicator variable with the value of 1 if firm i reports negative net income in the previous year and 0 otherwise. 
Table 5-4 (v)

Regression analysis of discretionary accruals with rule of law

(Dependent variable is signed discretionary accruals: DACCR)

\begin{tabular}{|c|c|c|c|c|c|c|c|c|c|c|}
\hline $\begin{array}{l}\text { Independent } \\
\text { variables }\end{array}$ & $\begin{array}{c}\text { Pooled } \\
\text { Estimate } \\
\text { (p-value) }\end{array}$ & $\begin{array}{c}1999 \\
\text { Estimate } \\
\text { (p-value) }\end{array}$ & $\begin{array}{c}\mathbf{2 0 0 0} \\
\text { Estimate } \\
\text { (p-value) }\end{array}$ & $\begin{array}{c}\mathbf{2 0 0 1} \\
\text { Estimate } \\
\text { (p-value) }\end{array}$ & $\begin{array}{c}\mathbf{2 0 0 2} \\
\text { Estimate } \\
\text { (p-value) }\end{array}$ & $\begin{array}{c}\mathbf{2 0 0 3} \\
\text { Estimate } \\
\text { (p-value) }\end{array}$ & $\begin{array}{c}2004 \\
\text { Estimate } \\
\text { (p-value) }\end{array}$ & $\begin{array}{c}\mathbf{2 0 0 5} \\
\text { Estimate } \\
\text { (p-value) }\end{array}$ & $\begin{array}{c}\mathbf{2 0 0 6} \\
\text { Estimate } \\
\text { (p-value) }\end{array}$ & $\begin{array}{c}\mathbf{2 0 0 7} \\
\text { Estimate } \\
\text { (p-value) }\end{array}$ \\
\hline Constant & $\begin{array}{c}-.304 \\
(<0.01)\end{array}$ & $\begin{array}{l}-.289 \\
(<0.01)\end{array}$ & $\begin{array}{l}-.250 \\
(<0.01)\end{array}$ & $\begin{array}{l}-.315 \\
(<0.01)\end{array}$ & $\begin{array}{l}-.346 \\
(<0.01)\end{array}$ & $\begin{array}{c}-.320 \\
(<0.01)\end{array}$ & $\begin{array}{l}-.287 \\
(<0.01)\end{array}$ & $\begin{array}{l}-.279 \\
(<0.01)\end{array}$ & $\begin{array}{l}-.303 \\
(<0.01)\end{array}$ & $\begin{array}{l}-.326 \\
(<0.01)\end{array}$ \\
\hline RLAW & $\begin{array}{c}-.027 \\
(<0.01)\end{array}$ & $\begin{array}{c}-.027 \\
(<0.01)\end{array}$ & $\begin{array}{c}-.025 \\
(<0.01)\end{array}$ & $\begin{array}{c}-.046 \\
(<0.01)\end{array}$ & $\begin{array}{c}-.032 \\
(<0.01)\end{array}$ & $\begin{array}{c}-.024 \\
(<0.01)\end{array}$ & $\begin{array}{c}-.019 \\
(<0.01)\end{array}$ & $\begin{array}{c}-.021 \\
(<0.01)\end{array}$ & $\begin{array}{c}-.025 \\
(<0.01)\end{array}$ & $\begin{array}{c}-.027 \\
(<0.01)\end{array}$ \\
\hline SIZE & $\begin{array}{c}.014 \\
(<0.01)\end{array}$ & $\begin{array}{c}.010 \\
(<0.01)\end{array}$ & $\begin{array}{l}.004 \\
(.168)\end{array}$ & $\begin{array}{c}.021 \\
(<0.01)\end{array}$ & $\begin{array}{c}.024 \\
(<0.01)\end{array}$ & $\begin{array}{c}.015 \\
(<0.01)\end{array}$ & $\begin{array}{c}.008 \\
(<0.01)\end{array}$ & $\begin{array}{c}.010 \\
(<0.01)\end{array}$ & $\begin{array}{c}.013 \\
(<0.01)\end{array}$ & $\begin{array}{c}.020 \\
(<0.01)\end{array}$ \\
\hline LEV & $\begin{array}{l}.019 \\
(<0.01)\end{array}$ & $\begin{array}{c}.024 \\
(<0.01)\end{array}$ & $\begin{array}{l}.028 \\
(<0.01)\end{array}$ & $\begin{array}{l}.026 \\
(<0.01)\end{array}$ & $\begin{array}{l}.023 \\
(<0.01)\end{array}$ & $\begin{array}{c}.015 \\
(<0.01)\end{array}$ & $\begin{array}{c}.015 \\
(<0.01)\end{array}$ & $\begin{array}{l}.016 \\
(<0.01)\end{array}$ & $\begin{array}{l}.017 \\
(<0.01)\end{array}$ & $\begin{array}{c}.016 \\
(<0.01)\end{array}$ \\
\hline GWTH & $\begin{array}{c}.053 \\
(<0.01)\end{array}$ & $\begin{array}{c}.051 \\
(<0.01)\end{array}$ & $\begin{array}{c}.043 \\
(<0.01)\end{array}$ & $\begin{array}{c}.048 \\
(<0.01)\end{array}$ & $\begin{array}{c}.041 \\
(<0.01)\end{array}$ & $\begin{array}{c}.040 \\
(<0.01)\end{array}$ & $\begin{array}{c}.052 \\
(<0.01)\end{array}$ & $\begin{array}{c}.055 \\
(<0.01)\end{array}$ & $\begin{array}{c}.070 \\
(<0.01)\end{array}$ & $\begin{array}{c}.064 \\
(<0.01)\end{array}$ \\
\hline $\mathrm{CFO}$ & $\begin{array}{c}-.449 \\
(<0.01)\end{array}$ & $\begin{array}{l}-.308 \\
(<0.01)\end{array}$ & $\begin{array}{l}-.220 \\
(<0.01)\end{array}$ & $\begin{array}{l}-.331 \\
(<0.01)\end{array}$ & $\begin{array}{l}-.419 \\
(<0.01)\end{array}$ & $\begin{array}{c}-.439 \\
(<0.01)\end{array}$ & $\begin{array}{l}-.450 \\
(<0.01)\end{array}$ & $\begin{array}{l}-.467 \\
(<0.01)\end{array}$ & $\begin{array}{c}-.448 \\
(<0.01)\end{array}$ & $\begin{array}{c}-.481 \\
(<0.01)\end{array}$ \\
\hline CAP & $\begin{array}{l}.449 \\
(<0.01)\end{array}$ & $\begin{array}{c}.465 \\
(<0.01)\end{array}$ & $\begin{array}{c}.418 \\
(<0.01)\end{array}$ & $\begin{array}{c}.390 \\
(<0.01)\end{array}$ & $\begin{array}{c}.402 \\
(<0.01)\end{array}$ & $\begin{array}{c}.459 \\
(<0.01)\end{array}$ & $\begin{array}{c}.469 \\
(<0.01)\end{array}$ & $\begin{array}{c}.450 \\
(<0.01)\end{array}$ & $\begin{array}{c}.472 \\
(<0.01)\end{array}$ & $\begin{array}{c}.480 \\
(<0.01)\end{array}$ \\
\hline LOSS & $\begin{array}{l}-.134 \\
(<0.01)\end{array}$ & $\begin{array}{l}-.161 \\
(<0.01)\end{array}$ & $\begin{array}{l}-.173 \\
(<0.01)\end{array}$ & $\begin{array}{l}.129 \\
(<0.01)\end{array}$ & $\begin{array}{l}-.130 \\
(<0.01)\end{array}$ & $\begin{array}{l}-.117 \\
(<0.01)\end{array}$ & $\begin{array}{c}-.121 \\
(<0.01)\end{array}$ & $\begin{array}{l}-.126 \\
(<0.01)\end{array}$ & $\begin{array}{c}-.132 \\
(<0.01)\end{array}$ & $\begin{array}{l}-.139 \\
(<0.01)\end{array}$ \\
\hline fixed effects & included & included & included & included & included & included & included & included & included & included \\
\hline Adj. $\mathbf{R}^{2}$ & .424 & .353 & .315 & .393 & .422 & .476 & .472 & .445 & .454 & .464 \\
\hline $\mathbf{N}$ & 156,906 & 156,906 & 156,906 & 156,906 & 156,906 & 156,906 & 156,906 & 156,906 & 156,906 & 156,906 \\
\hline
\end{tabular}

Note: Coefficient p-values applied two-tail and based on asymptotic Z-statistic robust to hetroscedasticity and country clustering effects using the method in Rogers (1993). For clarity in presentation the coefficients on year and country dummies have not been reported.

DACCR = signed discretionary accruals. RLAW = rule of law (WB 1999-2007). SIZE = natural logarithm of total assets in $\$$ thousands for firm i in year t. LEV= total long-term debt/equity for firm $\mathrm{i}$ in year $\mathrm{t}$. GWTH $=$ sales growth rate, defined as the sales in year $\mathrm{t}$ minus sales in $\mathrm{t}-1$ and scaled by sales in year $\mathrm{t}$. CFO $=$ operating cash flows for firm i in year t scaled by lagged total assets. CAP $=$ non-current (fixed) assets in year $\mathrm{t} /$ Total assets in year $\mathrm{t}$. LOSS $=$ indicator variable with the value of 1 if firm $i$ reports negative net income in the previous year and 0 otherwise. 
Table 5-4 (vi)

Regression analysis of discretionary accruals with press freedom

(Dependent variable is signed discretionary accruals: DACCR)

$\mathbf{D A C C R}_{\mathrm{it}}=\beta_{0}+\boldsymbol{\beta}_{1} \mathbf{P R E S S}+\beta_{2} \mathrm{SIZE}_{\mathrm{it}}+\beta_{3} \mathrm{LEV}_{\mathrm{it}}+\beta_{4} \mathrm{GWTH}_{\mathrm{it}}+\beta_{5} \mathrm{CFO}_{\mathrm{it}}+\beta_{6} \mathrm{CAP}_{\mathrm{it}}+\beta_{7} \mathrm{LOSS}_{\mathrm{it}}+$ fixed effects

\begin{tabular}{|c|c|c|c|c|c|c|c|c|c|c|}
\hline Independent & Pooled & 1999 & 2000 & 2001 & 2002 & 2003 & 2004 & 2005 & 2006 & 2007 \\
\hline & $\begin{array}{l}\text { Estimate } \\
\text { (p-value) }\end{array}$ & $\begin{array}{l}\text { Estimate } \\
\text { (p-value) }\end{array}$ & $\begin{array}{l}\text { Estimate } \\
\text { (p-value) }\end{array}$ & $\begin{array}{l}\text { Estimate } \\
\text { (p-value) }\end{array}$ & $\begin{array}{l}\text { Estimate } \\
\text { (p-value) }\end{array}$ & $\begin{array}{l}\text { Estimate } \\
\text { (p-value) }\end{array}$ & $\begin{array}{l}\text { Estimate } \\
\text { (p-value) }\end{array}$ & $\begin{array}{l}\text { Estimate } \\
\text { (p-value) }\end{array}$ & $\begin{array}{l}\text { Estimate } \\
\text { (p-value) }\end{array}$ & $\begin{array}{l}\text { Estimate } \\
\text { (p-value) }\end{array}$ \\
\hline Constant & $\begin{array}{c}-.314 \\
(<0.01)\end{array}$ & $\begin{array}{c}-.309 \\
(<0.01)\end{array}$ & $\begin{array}{c}-.272 \\
(<0.01)\end{array}$ & $\begin{array}{c}-.342 \\
(<0.01)\end{array}$ & $\begin{array}{c}-.361 \\
(<0.01)\end{array}$ & $\begin{array}{c}-.331 \\
(<0.01)\end{array}$ & $\begin{array}{c}-.294 \\
(<0.01)\end{array}$ & $\begin{array}{c}-.284 \\
(<0.01)\end{array}$ & $\begin{array}{c}-.308 \\
(<0.01)\end{array}$ & $\begin{array}{c}-.348 \\
(<0.01)\end{array}$ \\
\hline PRESS & $\begin{array}{c}-.017 \\
(<0.01)\end{array}$ & $\begin{array}{l}-.014 \\
(.019)\end{array}$ & $\begin{array}{l}-.009 \\
(.145)\end{array}$ & $\begin{array}{c}-.033 \\
(<0.01)\end{array}$ & $\begin{array}{c}-.023 \\
(<0.01)\end{array}$ & $\begin{array}{c}-.011 \\
(<0.01)\end{array}$ & $\begin{array}{c}-.008 \\
(<0.01)\end{array}$ & $\begin{array}{c}-.008 \\
(<0.01)\end{array}$ & $\begin{array}{c}-.012 \\
(<0.01)\end{array}$ & $\begin{array}{c}-.016 \\
(<0.01)\end{array}$ \\
\hline SIZE & $\begin{array}{c}.012 \\
(<0.01)\end{array}$ & $\begin{array}{l}.009 \\
(.001)\end{array}$ & $\begin{array}{l}.003 \\
(.255)\end{array}$ & $\begin{array}{c}.021 \\
(<0.01)\end{array}$ & $\begin{array}{c}.024 \\
(<0.01)\end{array}$ & $\begin{array}{c}.013 \\
(<0.01)\end{array}$ & $\begin{array}{c}.006 \\
(<0.01)\end{array}$ & $\begin{array}{l}.007 \\
(<0.01)\end{array}$ & $\begin{array}{c}.010 \\
(<0.01)\end{array}$ & $\begin{array}{c}.019 \\
(<0.01)\end{array}$ \\
\hline LEV & $\begin{array}{c}.020 \\
(<0.01)\end{array}$ & $\begin{array}{c}.024 \\
(<0.01)\end{array}$ & $\begin{array}{c}.028 \\
(<0.01)\end{array}$ & $\begin{array}{c}.026 \\
(<0.01)\end{array}$ & $\begin{array}{c}.024 \\
(<0.01)\end{array}$ & $\begin{array}{c}.016 \\
(<0.01)\end{array}$ & $\begin{array}{l}.015 \\
(<0.01)\end{array}$ & $\begin{array}{l}.016 \\
(<0.01)\end{array}$ & $\begin{array}{l}.018 \\
(<0.01)\end{array}$ & $\begin{array}{c}.017 \\
(<0.01)\end{array}$ \\
\hline GWTH & $\begin{array}{c}.054 \\
(<0.01)\end{array}$ & $\begin{array}{c}.051 \\
(<0.01)\end{array}$ & $\begin{array}{c}.043 \\
(<0.01)\end{array}$ & $\begin{array}{c}.050 \\
(<0.01)\end{array}$ & $\begin{array}{c}.042 \\
(<0.01)\end{array}$ & $\begin{array}{c}.041 \\
(<0.01)\end{array}$ & $\begin{array}{c}.053 \\
(<0.01)\end{array}$ & $\begin{array}{c}.056 \\
(<0.01)\end{array}$ & $\begin{array}{c}.072 \\
(<0.01)\end{array}$ & $\begin{array}{c}.065 \\
(<0.01)\end{array}$ \\
\hline $\mathrm{CFO}$ & $\begin{array}{c}-.403 \\
(<0.01)\end{array}$ & $\begin{array}{c}-.308 \\
(<0.01)\end{array}$ & $\begin{array}{c}-.219 \\
(<0.01)\end{array}$ & $\begin{array}{l}-.340 \\
(<0.01)\end{array}$ & $\begin{array}{c}-.420 \\
(<0.01)\end{array}$ & $\begin{array}{c}-.443 \\
(<0.01)\end{array}$ & $\begin{array}{c}-.452 \\
(<0.01)\end{array}$ & $\begin{array}{l}-.470 \\
(<0.01)\end{array}$ & $\begin{array}{c}-.450 \\
(<0.01)\end{array}$ & $\begin{array}{c}-.483 \\
(<0.01)\end{array}$ \\
\hline CAP & $\begin{array}{c}.455 \\
(<0.01)\end{array}$ & $\begin{array}{c}.471 \\
(<0.01)\end{array}$ & $\begin{array}{c}.424 \\
(<0.01)\end{array}$ & $\begin{array}{c}.399 \\
(<0.01)\end{array}$ & $\begin{array}{c}-.420 \\
(<0.01)\end{array}$ & $\begin{array}{c}.466 \\
(<0.01)\end{array}$ & $\begin{array}{c}.475 \\
(<0.01)\end{array}$ & $\begin{array}{c}.459 \\
(<0.01)\end{array}$ & $\begin{array}{c}.481 \\
(<0.01)\end{array}$ & $\begin{array}{c}.486 \\
(<0.01)\end{array}$ \\
\hline LOSS & $\begin{array}{c}-.136 \\
(<0.01)\end{array}$ & $\begin{array}{c}-.163 \\
(<0.01)\end{array}$ & $\begin{array}{l}-.176 \\
(<0.01)\end{array}$ & $\begin{array}{c}-.134 \\
(<0.01)\end{array}$ & $\begin{array}{c}-.131 \\
(<0.01)\end{array}$ & $\begin{array}{c}-.120 \\
(<0.01)\end{array}$ & $\begin{array}{c}-.123 \\
(<0.01)\end{array}$ & $\begin{array}{l}-.129 \\
(<0.01)\end{array}$ & $\begin{array}{l}-.135 \\
(<0.01)\end{array}$ & $\begin{array}{l}-.142 \\
(<0.01)\end{array}$ \\
\hline fixed effects & included & included & included & included & included & included & included & included & included & included \\
\hline Adj. $\mathbf{R}^{2}$ & .420 & .350 & .312 & .382 & .417 & .471 & .468 & .440 & .448 & .458 \\
\hline $\mathbf{N}$ & 156,906 & 156,906 & 156,906 & 156,906 & 156,906 & 156,906 & 156,906 & 156,906 & 156,906 & 156,906 \\
\hline
\end{tabular}

Note: Coefficient p-values applied two-tail and based on asymptotic Z-statistic robust to hetroscedasticity and country clustering effects using the method in Rogers (1993). For clarity in presentation the coefficients on year and country dummies have not been reported.

DACCR = signed discretionary accruals. PRESS $=$ press freedom $($ WB 1999-2007). SIZE $=$ natural logarithm of total assets in $\$$ thousands for firm i in year t. $\mathbf{L E V}=$ total long-term debt/equity for firm i in year t. GWTH = sales growth rate, defined as the sales in year t minus sales in t- 1 and scaled by sales in year t. CFO = operating cash flows for firm i in year t scaled by lagged total assets. CAP $=$ non-current (fixed) assets in year $\mathrm{t} /$ Total assets in year $\mathrm{t}$. LOSS $=$ indicator variable with the value of 1 if firm $i$ reports negative net income in the previous year and 0 otherwise. 
The six enforcement variable results are reported in both pooled and year wise cross sectional form tested one at a time. All models are significant with adjusted $\mathrm{R}^{2}$ of 31 to 47 percent, and the significance levels of individual coefficients are reported as two-tail p-values. The negative association between enforcement and discretionary accruals as the empirical indicator of earnings management is similar to the findings of La Porta et al. (1998; 2002 and 2006); Luez et al. (2003) and Francis and Wang (2008). They found that strong enforcement is strongly associated with lower levels of earnings management. The findings of the current study are consistent with the Daske et al. (2008) argument that country level strong enforcement decreases the managerial discretionary behaviour. Control variables are in most cases consistent with earlier studies.

\subsubsection{Test results for research question two: Institutional setting}

The second research question focuses on the impact of the institutional setting on empirical indicator of earnings management. Singapore, Hong Kong, Luxemburg, Denmark, Finland and United Kingdom have the highest institutional settings scores;

Venezuela, Ecuador, Nigeria, Argentina and Bangladesh have the lowest (Table 5-1, Panel B, Appendix A).

The regression results are reported in Table 5-5. The institutional settings variable is significant at $\mathrm{p}<.01$ in all models, both pooled and year wise and adjusted $\mathrm{R}^{2}$ range from 31 percent to 47 percent. This suggests that strong country level institutional settings reduce earnings management. The negative association between institutional settings and the empirical indicator of earnings management is similar to 
the findings of Dyck and Zingales (2003); Shleifer and Vishny (1997); Peter (2004); Belkaoui and AlNajjar (2006) recommend strengthening of the institutional base to reduce insiders' private control and earnings management activities. The impact of the control variables is generally consistent with the earlier results of prior studies. 
Table 5-5

Regression analysis of discretionary accruals with institutional setting

(Dependent variable is signed discretionary accruals: DACCR)

$\mathbf{D A C C R}_{\text {it }}=\beta_{0}+\boldsymbol{\beta}_{1} \mathbf{I N S}+\beta_{2} \mathrm{SIZE}_{\mathrm{it}}+\beta_{3} \mathrm{LEV}_{\mathrm{it}}+\beta_{4} \mathrm{GWTH}_{\mathrm{it}}+\beta_{5} \mathrm{CFO}_{\mathrm{it}}+\beta_{6} \mathrm{CAP}_{\mathrm{it}}+\beta_{7} \mathrm{LOSS}_{\mathrm{it}}+$ fixed effects

\begin{tabular}{|c|c|c|c|c|c|c|c|c|c|c|}
\hline \multirow{2}{*}{$\begin{array}{l}\text { Independent } \\
\text { variables }\end{array}$} & Pooled & 1999 & 2000 & 2001 & 2002 & 2003 & 2004 & 2005 & 2006 & 2007 \\
\hline & $\begin{array}{l}\text { Estimate } \\
\text { (p-value) }\end{array}$ & $\begin{array}{l}\text { Estimate } \\
\text { (p-value) }\end{array}$ & $\begin{array}{l}\text { Estimate } \\
\text { (p-value) }\end{array}$ & $\begin{array}{l}\text { Estimate } \\
\text { (p-value) }\end{array}$ & $\begin{array}{l}\text { Estimate } \\
\text { (p-value) }\end{array}$ & $\begin{array}{l}\text { Estimate } \\
\text { (p-value) }\end{array}$ & $\begin{array}{l}\text { Estimate } \\
\text { (p-value) }\end{array}$ & $\begin{array}{l}\text { Estimate } \\
\text { (p-value) }\end{array}$ & $\begin{array}{l}\text { Estimate } \\
\text { (p-value) }\end{array}$ & $\begin{array}{l}\text { Estimate } \\
\text { (p-value) }\end{array}$ \\
\hline Constant & $\begin{array}{c}-.308 \\
(<0.01)\end{array}$ & $\begin{array}{c}-.285 \\
(<0.01)\end{array}$ & $\begin{array}{c}-.245 \\
(<0.01)\end{array}$ & $\begin{array}{c}-.310 \\
(<0.01)\end{array}$ & $\begin{array}{c}-.349 \\
(<0.01)\end{array}$ & $\begin{array}{c}-.322 \\
(<0.01)\end{array}$ & $\begin{array}{c}-.289 \\
(<0.01)\end{array}$ & $\begin{array}{c}-.282 \\
(<0.01)\end{array}$ & $\begin{array}{c}-.307 \\
(<0.01)\end{array}$ & $\begin{array}{c}-.335 \\
(<0.01)\end{array}$ \\
\hline INS & $\begin{array}{c}-.028 \\
(<0.01)\end{array}$ & $\begin{array}{c}-.032 \\
(<0.01)\end{array}$ & $\begin{array}{c}-.032 \\
(<0.01)\end{array}$ & $\begin{array}{c}-.056 \\
(<0.01)\end{array}$ & $\begin{array}{c}-.035 \\
(<0.01)\end{array}$ & $\begin{array}{c}-.025 \\
(<0.01)\end{array}$ & $\begin{array}{c}-.019 \\
(<0.01)\end{array}$ & $\begin{array}{c}-.025 \\
(<0.01)\end{array}$ & $\begin{array}{c}-.030 \\
(<0.01)\end{array}$ & $\begin{array}{c}-.030 \\
(<0.01)\end{array}$ \\
\hline SIZE & $\begin{array}{c}.015 \\
(<0.01)\end{array}$ & $\begin{array}{c}.010 \\
(<0.01)\end{array}$ & $\begin{array}{l}.005 \\
(.128)\end{array}$ & $\begin{array}{c}.022 \\
(<0.01)\end{array}$ & $\begin{array}{c}.025 \\
(<0.01)\end{array}$ & $\begin{array}{c}.015 \\
(<0.01)\end{array}$ & $\begin{array}{l}.008 \\
(<0.01)\end{array}$ & $\begin{array}{c}.011 \\
(<0.01)\end{array}$ & $\begin{array}{c}.014 \\
(<0.01)\end{array}$ & $\begin{array}{c}.021 \\
(<0.01)\end{array}$ \\
\hline LEV & $\begin{array}{c}.019 \\
(<0.01)\end{array}$ & $\begin{array}{c}.024 \\
(<0.01)\end{array}$ & $\begin{array}{c}.028 \\
(<0.01)\end{array}$ & $\begin{array}{c}.025 \\
(<0.01)\end{array}$ & $\begin{array}{c}.023 \\
(<0.01)\end{array}$ & $\begin{array}{c}.015 \\
(<0.01)\end{array}$ & $\begin{array}{l}.014 \\
(<0.01)\end{array}$ & $\begin{array}{c}.015 \\
(<0.01)\end{array}$ & $\begin{array}{c}.017 \\
(<0.01)\end{array}$ & $\begin{array}{c}.016 \\
(<0.01)\end{array}$ \\
\hline GWTH & $\begin{array}{c}.053 \\
(<0.01)\end{array}$ & $\begin{array}{c}.051 \\
(<0.01)\end{array}$ & $\begin{array}{c}.043 \\
(<0.01)\end{array}$ & $\begin{array}{c}.048 \\
(<0.01)\end{array}$ & $\begin{array}{c}.041 \\
(<0.01)\end{array}$ & $\begin{array}{c}.040 \\
(<0.01)\end{array}$ & $\begin{array}{l}.052 \\
(<0.01)\end{array}$ & $\begin{array}{c}.054 \\
(<0.01)\end{array}$ & $\begin{array}{l}.070 \\
(<0.01)\end{array}$ & $\begin{array}{c}.064 \\
(<0.01)\end{array}$ \\
\hline $\mathrm{CFO}$ & $\begin{array}{l}-.403 \\
(<0.01)\end{array}$ & $\begin{array}{c}-.308 \\
(<0.01)\end{array}$ & $\begin{array}{l}-.220 \\
(<0.01)\end{array}$ & $\begin{array}{c}-.333 \\
(<0.01)\end{array}$ & $\begin{array}{l}-.422 \\
(<0.01)\end{array}$ & $\begin{array}{c}-.442 \\
(<0.01)\end{array}$ & $\begin{array}{l}-.452 \\
(<0.01)\end{array}$ & $\begin{array}{l}-.468 \\
(<0.01)\end{array}$ & $\begin{array}{c}-.449 \\
(<0.01)\end{array}$ & $\begin{array}{l}-.483 \\
(<0.01)\end{array}$ \\
\hline CAP & $\begin{array}{c}.451 \\
(<0.01)\end{array}$ & $\begin{array}{l}.466 \\
(<0.01)\end{array}$ & $\begin{array}{c}.418 \\
(<0.01)\end{array}$ & $\begin{array}{c}.391 \\
(<0.01)\end{array}$ & $\begin{array}{c}.404 \\
(<0.01)\end{array}$ & $\begin{array}{c}.461 \\
(<0.01)\end{array}$ & $\begin{array}{l}.471 \\
(<0.01)\end{array}$ & $\begin{array}{c}.450 \\
(<0.01)\end{array}$ & $\begin{array}{c}.472 \\
(<0.01)\end{array}$ & $\begin{array}{l}.481 \\
(<0.01)\end{array}$ \\
\hline LOSS & $\begin{array}{c}-.134 \\
(<0.01)\end{array}$ & $\begin{array}{l}-.160 \\
(<0.01)\end{array}$ & $\begin{array}{l}-.173 \\
(<0.01)\end{array}$ & $\begin{array}{l}-.129 \\
(<0.01)\end{array}$ & $\begin{array}{l}-.129 \\
(<0.01)\end{array}$ & $\begin{array}{c}-.117 \\
(<0.01)\end{array}$ & $\begin{array}{c}-.121 \\
(<0.01)\end{array}$ & $\begin{array}{l}-.126 \\
(<0.01)\end{array}$ & $\begin{array}{c}-.131 \\
(<0.01)\end{array}$ & $\begin{array}{c}-.139 \\
(<0.01)\end{array}$ \\
\hline fixed effects & included & included & included & included & included & included & included & included & included & included \\
\hline Adj. $\mathbf{R}^{2}$ & .417 & .353 & .315 & .392 & .421 & .475 & .471 & .445 & .455 & .462 \\
\hline $\mathbf{N}$ & 156,906 & 156,906 & 156,906 & 156,906 & 156,906 & 156,906 & 156,906 & 156,906 & 156,906 & 156,906 \\
\hline
\end{tabular}

Note: Coefficient p-values applied two-tail and based on asymptotic Z-statistic robust to hetroscedasticity and country clustering effects using the method in Rogers (1993). For clarity in presentation the coefficients on year and country dummies have not been reported.

DACCR = signed discretionary accruals. INS = regulatory quality (WB 1999-2007). SIZE $=$ natural logarithm of total assets in $\$$ thousands for firm i in year t. $\mathbf{L E V}=$ total long-term debt/equity for firm i in year t. GWTH = sales growth rate, defined as the sales in year t minus sales in t-1 and scaled by sales in year t. CFO = operating cash flows for firm $\mathrm{i}$ in year $\mathrm{t}$ scaled by lagged total assets. $\mathbf{C A P}=$ non-current (fixed) assets in year $\mathrm{t} /$ Total assets in year $\mathrm{t}$. LOSS $=$ indicator variable with the value of 1 if firm i reports negative net income in the previous year and 0 otherwise. 


\subsubsection{Test results for research question three: Political system}

Research question three relates the macro governance variable political stability to earnings management. Table 5-6 present estimation results for both pooled and year specification of the association between political stability and discretionary accruals. Table 5-1, panel A, appendix A, provides the summary statistics of political stability scores by country and show that countries such as Luxemburg, Finland, Switzerland, Netherlands and Norway have the highest scores, while Nigeria, Pakistan, Srilanka, Colombia and Bangladesh have the least political stability. Table 5-1, panel C, appendix A, presents Pearson correlation coefficients for the variables used in this study. Panel $\mathrm{C}$ reports the there is a negative association between country-level political stability and discretionary accruals (DACCR), significant at $\mathrm{p}<.01$.

Table 5-6 reports regression results for the analysis of the relationship between political stability and earnings management. The political stability (POL) variable is significant in all models both pooled and year wise specifications and the adjusted $\mathrm{R}^{2}$ range from 32 percent to 47 percent. This suggests that strong country level political stability reduce the earnings management practices. The results are similar to the findings of Seligson (2002); Alam (1995); Rose-Ackerman (1978); and Tanzi (1998). Shleifer and Vishny (1993) indicate that, "the first step to reduce accounting irregularities should be to create an accounting system that prevents theft from the government". Further Tanzi and Davoodi (1997) explain that less political stability encourages irregularities in government budgeting - it is highly likely when "some of the essential controlling or auditing institutions are not well developed". Regarding the control variables, the coefficient on CFO is negative and statistically 
significant at $(\mathrm{p}<.01)$ level. The SIZE coefficient is positive and significant at $(\mathrm{p}<.01)$ level implying that larger firms make more income increasing DACCR choices consistent with larger firms having more ability to generate accruals. The coefficient on LEV is positive in all the year examined and statistically significant at $(\mathrm{p}<.01)$. GWTH coefficient is positive and statistically significant in the pooled model supporting McNichols hypothesis that growth firms generate more accruals. Capital intensity (CAP) as well as the loss dummy (LOSS) are also found significant at $(p<.01)$ level in both the pooled and year wise specifications.

The adjusted $\mathrm{R}^{2}$ values indicate that the regression model provides a good fit to the data. White's test for hetroscedasticity indicates that the residuals from the regression model are homoskedastic. The variation inflation factor (VIF) values ranged from 1.09 to 2.41 , and thus can reject multicollinearity in the data. 
Table 5-6

Regression analysis of discretionary accruals with political system

(Dependent variable is signed discretionary accruals: DACCR)

\begin{tabular}{|c|c|c|c|c|c|c|c|c|c|c|}
\hline $\begin{array}{l}\text { Independent } \\
\text { variables }\end{array}$ & Pooled & 1999 & 2000 & 2001 & 2002 & 2003 & 2004 & 2005 & 2006 & 2007 \\
\hline & $\begin{array}{l}\text { Estimate } \\
\text { (p-value) }\end{array}$ & $\begin{array}{l}\text { Estimate } \\
\text { (p-value) }\end{array}$ & $\begin{array}{l}\text { Estimate } \\
\text { (p-value) }\end{array}$ & $\begin{array}{l}\text { Estimate } \\
\text { (p-value) }\end{array}$ & $\begin{array}{l}\text { Estimate } \\
\text { (p-value) }\end{array}$ & $\begin{array}{l}\text { Estimate } \\
\text { (p-value) }\end{array}$ & $\begin{array}{l}\text { Estimate } \\
\text { (p-value) }\end{array}$ & $\begin{array}{l}\text { Estimate } \\
\text { (p-value) }\end{array}$ & $\begin{array}{l}\text { Estimate } \\
\text { (p-value) }\end{array}$ & $\begin{array}{l}\text { Estimate } \\
\text { (p-value) }\end{array}$ \\
\hline Constant & $\begin{array}{c}-.323 \\
(<0.01)\end{array}$ & $\begin{array}{c}-.255 \\
(<0.01)\end{array}$ & $\begin{array}{l}-.208 \\
(<0.01)\end{array}$ & $\begin{array}{c}-.362 \\
(<0.01)\end{array}$ & $\begin{array}{c}-.375 \\
(<0.01)\end{array}$ & $\begin{array}{c}-.338 \\
(<0.01)\end{array}$ & $\begin{array}{c}-.300 \\
(<0.01)\end{array}$ & $\begin{array}{l}-.293 \\
(<0.01)\end{array}$ & $\begin{array}{l}-.319 \\
(<0.01)\end{array}$ & $\begin{array}{l}-.351 \\
(<0.01)\end{array}$ \\
\hline POL & $\begin{array}{c}-.020 \\
(<0.01)\end{array}$ & $\begin{array}{l}-.018 \\
(.002)\end{array}$ & $\begin{array}{l}-.014 \\
(.026)\end{array}$ & $\begin{array}{c}-.019 \\
(<0.01)\end{array}$ & $\begin{array}{c}-.020 \\
(<0.01)\end{array}$ & $\begin{array}{c}-.014 \\
(<0.01)\end{array}$ & $\begin{array}{c}-.013 \\
(<0.01)\end{array}$ & $\begin{array}{c}-.014 \\
(<0.01)\end{array}$ & $\begin{array}{c}-.018 \\
(<0.01)\end{array}$ & $\begin{array}{c}-.018 \\
(<0.01)\end{array}$ \\
\hline SIZE & $\begin{array}{c}.014 \\
(<0.01)\end{array}$ & $\begin{array}{l}.010 \\
(.001)\end{array}$ & $\begin{array}{l}.006 \\
(.066)\end{array}$ & $\begin{array}{l}.020 \\
(<0.01)\end{array}$ & $\begin{array}{c}.023 \\
(<0.01)\end{array}$ & $\begin{array}{c}.014 \\
(<0.01)\end{array}$ & $\begin{array}{l}.007 \\
(<0.01)\end{array}$ & $\begin{array}{c}.009 \\
(<0.01)\end{array}$ & $\begin{array}{l}.012 \\
(<0.01)\end{array}$ & $\begin{array}{l}.019 \\
(<0.01)\end{array}$ \\
\hline LEV & $\begin{array}{c}.018 \\
(<0.01)\end{array}$ & $\begin{array}{c}.024 \\
(<0.01)\end{array}$ & $\begin{array}{c}.028 \\
(<0.01)\end{array}$ & $\begin{array}{l}.026 \\
(<0.01)\end{array}$ & $\begin{array}{c}.023 \\
(<0.01)\end{array}$ & $\begin{array}{c}.015 \\
(<0.01)\end{array}$ & $\begin{array}{c}.014 \\
(<0.01)\end{array}$ & $\begin{array}{c}.015 \\
(<0.01)\end{array}$ & $\begin{array}{c}.016 \\
(<0.01)\end{array}$ & $\begin{array}{c}.014 \\
(<0.01)\end{array}$ \\
\hline GWTH & $\begin{array}{c}.053 \\
(<0.01)\end{array}$ & $\begin{array}{c}.050 \\
(<0.01)\end{array}$ & $\begin{array}{c}.041 \\
(<0.01)\end{array}$ & $\begin{array}{l}.050 \\
(<0.01)\end{array}$ & $\begin{array}{c}.042 \\
(<0.01)\end{array}$ & $\begin{array}{c}.040 \\
(<0.01)\end{array}$ & $\begin{array}{c}.052 \\
(<0.01)\end{array}$ & $\begin{array}{c}.055 \\
(<0.01)\end{array}$ & $\begin{array}{c}.071 \\
(<0.01)\end{array}$ & $\begin{array}{c}.065 \\
(<0.01)\end{array}$ \\
\hline $\mathrm{CFO}$ & $\begin{array}{l}-.406 \\
(<0.01)\end{array}$ & $\begin{array}{c}-.304 \\
(<0.01)\end{array}$ & $\begin{array}{l}-.215 \\
(<0.01)\end{array}$ & $\begin{array}{c}-.341 \\
(<0.01)\end{array}$ & $\begin{array}{l}-.422 \\
(<0.01)\end{array}$ & $\begin{array}{c}-.445 \\
(<0.01)\end{array}$ & $\begin{array}{c}-.454 \\
(<0.01)\end{array}$ & $\begin{array}{c}-.471 \\
(<0.01)\end{array}$ & $\begin{array}{l}-.451 \\
(<0.01)\end{array}$ & $\begin{array}{l}-.486 \\
(<0.01)\end{array}$ \\
\hline CAP & $\begin{array}{c}.458 \\
(<0.01)\end{array}$ & $\begin{array}{c}.458 \\
(<0.01)\end{array}$ & $\begin{array}{l}.407 \\
(<0.01)\end{array}$ & $\begin{array}{l}.405 \\
(<0.01)\end{array}$ & $\begin{array}{c}.412 \\
(<0.01)\end{array}$ & $\begin{array}{l}.468 \\
(<0.01)\end{array}$ & $\begin{array}{l}.476 \\
(<0.01)\end{array}$ & $\begin{array}{c}.459 \\
(<0.01)\end{array}$ & $\begin{array}{c}.482 \\
(<0.01)\end{array}$ & $\begin{array}{l}.492 \\
(<0.01)\end{array}$ \\
\hline LOSS & $\begin{array}{c}-.139 \\
(<0.01)\end{array}$ & $\begin{array}{c}-.156 \\
(<0.01)\end{array}$ & $\begin{array}{l}-.167 \\
(<0.01)\end{array}$ & $\begin{array}{l}-.137 \\
(<0.01)\end{array}$ & $\begin{array}{c}-.134 \\
(<0.01)\end{array}$ & $\begin{array}{c}-.123 \\
(<0.01)\end{array}$ & $\begin{array}{c}-.125 \\
(<0.01)\end{array}$ & $\begin{array}{l}-.130 \\
(<0.01)\end{array}$ & $\begin{array}{l}-.137 \\
(<0.01)\end{array}$ & $\begin{array}{c}-.146 \\
(<0.01)\end{array}$ \\
\hline fixed effects & included & included & included & included & included & included & included & included & included & included \\
\hline Adj. $\mathbf{R}^{2}$ & .420 & .358 & .323 & .378 & .415 & .471 & .469 & .441 & .449 & .457 \\
\hline $\mathbf{N}$ & 156,906 & 156,906 & 156,906 & 156,906 & 156,906 & 156,906 & 156,906 & 156,906 & 156,906 & 156,906 \\
\hline
\end{tabular}

Note: Coefficient p-values applied two-tail and based on asymptotic Z-statistic robust to hetroscedasticity and country clustering effects using the method in Rogers (1993). For clarity in presentation the coefficients on year and country dummies have not been reported.

DACCR = signed discretionary accruals. POL $=$ political stability (WB 1999-2007). SIZE $=$ natural logarithm of total assets in $\$$ thousands for firm i in year t. $\mathbf{L E V}=$ total long-term debt/equity for firm i in year t. GWTH = sales growth rate, defined as the sales in year t minus sales in t-1 and scaled by sales in year t. CFO $=$ operating cash flows for firm $\mathrm{i}$ in year $\mathrm{t}$ scaled by lagged total assets. CAP $=$ non-current (fixed) assets in year $\mathrm{t} /$ Total assets in year $\mathrm{t}$. LOSS $=$ indicator variable with the value of 1 if firm i reports negative net income in the previous year and 0 otherwise. 


\subsubsection{Test results of research question four: Corruption}

To test for the impact of corruption it is necessary to have some measure of corruption. There have been many different proxies for corruption used in the literature: the number of political figures convicted for abuse of power (Fisman and Gatti 1999; Goel and Nelson 1998), management time with bureaucracy (Kaufmann and Wei 2000), and a number of survey methods measuring corruption within a country. In recent research, the latter form has been the preferred approach with The World Bank control of corruption index being one of the more popular. The control of corruption index is a survey, taking results from many other surveys and combining them to make an index of control of corruption (Treisman 2000). Jain (2001) offers a review of corruption in general, and covers many of the different ways that corruption has been measured.

Table 5-1, panel B, appendix A, report the summary statistics of corruption scores by country and shows that countries such as Finland, Denmark, New Zealand and Singapore have the highest scores, while Bangladesh, Nigeria, Indonesia, Venezuela and Paraguay have the lowest control of corruption. Table 5-1, panel D, appendix A, presents Pearson correlation coefficients for the variables used in this study. Panel D shows that there is a negative association between country-level control of corruption and discretionary accruals (DACCR), significant at $\mathrm{p}<.01$. These results also suggest that there is a significant relationship between the discretionary accruals and control of corruption.

Table 5-7 reports regression results for analysis of the impact of corruption on earnings management using both pooled and year wise specification. The corruption 
(COR) variable is significant at $\mathrm{p}<.01$ in all models, both pooled and year wise specifications and the adjusted $\mathrm{R}^{2}$ ranges from 31 percent to 47 percent. This suggests that strong country level control of corruption reduces earnings management practices. The results are similar to the findings of Hoopes et al. (2006), who recommend that better accounting and auditing quality can reduce corruption at a country level. The coefficient on size is positive and highly significant. Evidently earnings management is prevalent in larger firms, relative to smaller firms (Watts and Zimmerman 1986). As hypothesized, the coefficient of the leverage is significantly positive $(\mathrm{p}<.01)$ and the coefficient of growth also appear to impact earnings management. $\mathrm{CFO}$ is significantly negative $(\mathrm{p}<.01)$, capital intensity (CAP) is significantly positive $(\mathrm{p}<.01)$ and the loss dummy (LOSS) significantly negative $(\mathrm{p}<.01)$ 
Table 5-7

Regression analysis of discretionary accruals with corruption

(Dependent variable is signed discretionary accruals: DACCR)

$\mathbf{D A C C R}_{\mathrm{it}}=\beta_{0}+\boldsymbol{\beta}_{\mathbf{1}} \mathbf{P O L}+\beta_{2} \mathrm{SIZE}_{\mathrm{it}}+\beta_{3} \mathrm{LEV}_{\mathrm{it}}+\beta_{4} \mathrm{GWTH}_{\mathrm{it}}+\beta_{5} \mathrm{CFO}_{\mathrm{it}}+\beta_{6} \mathrm{CAP}_{\mathrm{it}}+\beta_{7} \mathrm{LOSS}_{\mathrm{it}}+$ fixed effects

\begin{tabular}{|c|c|c|c|c|c|c|c|c|c|c|}
\hline & Pooled & 1999 & 2000 & 2001 & 2002 & 2003 & 2004 & 2005 & 2006 & 2007 \\
\hline $\begin{array}{l}\text { Independent } \\
\text { variables }\end{array}$ & $\begin{array}{l}\text { Estimate } \\
\text { (p-value) }\end{array}$ & $\begin{array}{l}\text { Estimate } \\
\text { (p-value) }\end{array}$ & $\begin{array}{l}\text { Estimate } \\
\text { (p-value) }\end{array}$ & $\begin{array}{l}\text { Estimate } \\
\text { (p-value) }\end{array}$ & $\begin{array}{l}\text { Estimate } \\
\text { (p-value) }\end{array}$ & $\begin{array}{l}\text { Estimate } \\
\text { (p-value) }\end{array}$ & $\begin{array}{l}\text { Estimate } \\
\text { (p-value) }\end{array}$ & $\begin{array}{l}\text { Estimate } \\
\text { (p-value) }\end{array}$ & $\begin{array}{l}\text { Estimate } \\
\text { (p-value) }\end{array}$ & $\begin{array}{l}\text { Estimate } \\
\text { (p-value) }\end{array}$ \\
\hline Constant & $\begin{array}{l}-.311 \\
(<0.01)\end{array}$ & $\begin{array}{l}-.309 \\
(<0.01)\end{array}$ & $\begin{array}{l}-.268 \\
(<0.01)\end{array}$ & $\begin{array}{l}-.333 \\
(<0.01)\end{array}$ & $\begin{array}{l}-.360 \\
(<0.01)\end{array}$ & $\begin{array}{l}-.328 \\
(<0.01)\end{array}$ & $\begin{array}{l}-.292 \\
(<0.01)\end{array}$ & $\begin{array}{l}-.284 \\
(<0.01)\end{array}$ & $\begin{array}{l}-.309 \\
(<0.01)\end{array}$ & $\begin{array}{l}-.342 \\
(<0.01)\end{array}$ \\
\hline COR & $\begin{array}{c}-.021 \\
(<0.01)\end{array}$ & $\begin{array}{l}-.012 \\
(.002)\end{array}$ & $\begin{array}{l}-.012 \\
(.003)\end{array}$ & $\begin{array}{l}-.038 \\
(<0.01)\end{array}$ & $\begin{array}{c}-.026 \\
(<0.01)\end{array}$ & $\begin{array}{c}-.018 \\
(<0.01)\end{array}$ & $\begin{array}{c}-.012 \\
(<0.01)\end{array}$ & $\begin{array}{c}-.015 \\
(<0.01)\end{array}$ & $\begin{array}{c}-.019 \\
(<0.01)\end{array}$ & $\begin{array}{c}-.019 \\
(<0.01)\end{array}$ \\
\hline SIZE & $\begin{array}{c}.014 \\
(<0.01)\end{array}$ & $\begin{array}{l}.010 \\
(.001)\end{array}$ & $\begin{array}{c}.004 \\
(.212)\end{array}$ & $\begin{array}{l}.021 \\
(<0.01)\end{array}$ & $\begin{array}{c}.025 \\
(<0.01)\end{array}$ & $\begin{array}{l}.014 \\
(<0.01)\end{array}$ & $\begin{array}{l}.007 \\
(<0.01)\end{array}$ & $\begin{array}{c}.009 \\
(<0.01)\end{array}$ & $\begin{array}{c}.012 \\
(<0.01)\end{array}$ & $\begin{array}{c}.020 \\
(<0.01)\end{array}$ \\
\hline LEV & $\begin{array}{c}.019 \\
(<0.01)\end{array}$ & $\begin{array}{l}.024 \\
(<0.01)\end{array}$ & $\begin{array}{l}.028 \\
(<0.01)\end{array}$ & $\begin{array}{l}.026 \\
(<0.01)\end{array}$ & $\begin{array}{c}.023 \\
(<0.01)\end{array}$ & $\begin{array}{l}.015 \\
(<0.01)\end{array}$ & $\begin{array}{l}.015 \\
(<0.01)\end{array}$ & $\begin{array}{l}.015 \\
(<0.01)\end{array}$ & $\begin{array}{l}.017 \\
(<0.01)\end{array}$ & $\begin{array}{c}.016 \\
(<0.01)\end{array}$ \\
\hline GWTH & $\begin{array}{c}.053 \\
(<0.01)\end{array}$ & $\begin{array}{c}.051 \\
(<0.01)\end{array}$ & $\begin{array}{c}.043 \\
(<0.01)\end{array}$ & $\begin{array}{l}.049 \\
(<0.01)\end{array}$ & $\begin{array}{c}.042 \\
(<0.01)\end{array}$ & $\begin{array}{c}.040 \\
(<0.01)\end{array}$ & $\begin{array}{l}.052 \\
(<0.01)\end{array}$ & $\begin{array}{c}.055 \\
(<0.01)\end{array}$ & $\begin{array}{c}.071 \\
(<0.01)\end{array}$ & $\begin{array}{c}.065 \\
(<0.01)\end{array}$ \\
\hline $\mathrm{CFO}$ & $\begin{array}{l}-.403 \\
(<0.01)\end{array}$ & $\begin{array}{c}-.308 \\
(<0.01)\end{array}$ & $\begin{array}{l}-.220 \\
(<0.01)\end{array}$ & $\begin{array}{l}-.337 \\
(<0.01)\end{array}$ & $\begin{array}{l}-.422 \\
(<0.01)\end{array}$ & $\begin{array}{c}-.441 \\
(<0.01)\end{array}$ & $\begin{array}{c}-.451 \\
(<0.01)\end{array}$ & $\begin{array}{l}-.468 \\
(<0.01)\end{array}$ & $\begin{array}{l}-.449 \\
(<0.01)\end{array}$ & $\begin{array}{l}-.483 \\
(<0.01)\end{array}$ \\
\hline CAP & $\begin{array}{c}.452 \\
(<0.01)\end{array}$ & $\begin{array}{l}.471 \\
(<0.01)\end{array}$ & $\begin{array}{c}.423 \\
(<0.01)\end{array}$ & $\begin{array}{c}.396 \\
(<0.01)\end{array}$ & $\begin{array}{c}.406 \\
(<0.01)\end{array}$ & $\begin{array}{c}.462 \\
(<0.01)\end{array}$ & $\begin{array}{c}.473 \\
(<0.01)\end{array}$ & $\begin{array}{c}.454 \\
(<0.01)\end{array}$ & $\begin{array}{c}.475 \\
(<0.01)\end{array}$ & $\begin{array}{c}.484 \\
(<0.01)\end{array}$ \\
\hline LOSS & $\begin{array}{l}-.134 \\
(<0.01)\end{array}$ & $\begin{array}{c}-.162 \\
(<0.01)\end{array}$ & $\begin{array}{l}-.175 \\
(<0.01)\end{array}$ & $\begin{array}{l}-.132 \\
(<0.01)\end{array}$ & $\begin{array}{l}-.131 \\
(<0.01)\end{array}$ & $\begin{array}{c}-.119 \\
(<0.01)\end{array}$ & $\begin{array}{c}-.123 \\
(<0.01)\end{array}$ & $\begin{array}{l}-.128 \\
(<0.01)\end{array}$ & $\begin{array}{c}-.134 \\
(<0.01)\end{array}$ & $\begin{array}{l}-.142 \\
(<0.01)\end{array}$ \\
\hline fixed effects & included & included & included & included & included & included & included & included & included & included \\
\hline Adj. $\mathbf{R}^{2}$ & .423 & .349 & .312 & .387 & .420 & .474 & .470 & .443 & .452 & .460 \\
\hline $\mathbf{N}$ & 156,906 & 156,906 & 156,906 & 156,906 & 156,906 & 156,906 & 156,906 & 156,906 & 156,906 & 156,906 \\
\hline
\end{tabular}

Note: Coefficient p-values applied two-tail and based on asymptotic Z-statistic robust to hetroscedasticity and country clustering effects using the method in Rogers (1993). For clarity in presentation the coefficients on year and country dummies have not been reported.

DACCR = signed discretionary accruals. COR $=$ control of corruption (WB 1999-2007). SIZE $=$ natural logarithm of total assets in $\$$ thousands for firm i in year t. $\mathbf{L E V}=$ total long-term debt/equity for firm i in year $\mathrm{t}$. GWTH = sales growth rate, defined as the sales in year t minus sales in $\mathrm{t}-1$ and scaled by sales in year $\mathrm{t}$. CFO $=$ operating cash flows for firm $\mathrm{i}$ in year $\mathrm{t}$ scaled by lagged total assets. $\mathbf{C A P}=$ non-current (fixed) assets in year $\mathrm{t} /$ Total assets in year $\mathrm{t}$. LOSS $=$ indicator variable with the value of 1 if firm $i$ reports negative net income in the previous year and 0 otherwise. 


\subsubsection{Test results of research question five: Culture}

The fifth research question focuses on the impact of culture on earnings management.

Table 5-1, panel B, appendix A, provides the summary statistics of culture values by country. The table shows Finland and Sweden have highest culture values whereas the Philippines and Argentina have the lowest culture values, respectively 3.51 and 3.46. Table 5-1, panel D, appendix A, reports the there is a negative correlation between country-level culture values and discretionary accruals (DACCR), significant at $\mathrm{p}<.01$.

Table 5-8, reports regression results for analysis of the relationship between earnings management and culture. The culture (CUL) variable is significant at $p<.01$ in all models, both pooled and year wise specifications, and the adjusted $\mathrm{R}^{2}$ ranges from around 32 percent to 47 percent (except in the year 1999). This suggests that strong country level ethical practices reduce earnings management. The results for culture are similar to the findings of Hopes et al. (2008); Nabar and Boonlert-U-Thai (2007); and Guam et al. (2005), and suggest that culture is an important determinant of accounting choice and should be considered by standard setters enacting and enforcing financial reporting standards. The control variable results are in general consistent with earlier results. 
Table 5-8

Regression analysis of discretionary accruals with culture

(Dependent variable is signed discretionary accruals: DACCR)

$\mathbf{D A C C R}_{\text {it }}=\beta_{0}+\boldsymbol{\beta}_{\mathbf{1}} \mathbf{C U L}+\beta_{2} \mathrm{SIZE}_{\mathrm{it}}+\beta_{3} \mathrm{LEV}_{\mathrm{it}}+\beta_{4} \mathrm{GWTH}_{\mathrm{it}}+\beta_{5} \mathrm{CFO}_{\mathrm{it}}+\beta_{6} \mathrm{CAP}_{\mathrm{it}}+\beta_{7} \mathrm{LOSS}_{\mathrm{it}}+$ fixed effects

\begin{tabular}{|c|c|c|c|c|c|c|c|c|c|c|}
\hline \multirow{2}{*}{$\begin{array}{l}\text { Independent } \\
\text { variables }\end{array}$} & Pooled & 1999 & 2000 & 2001 & 2002 & 2003 & 2004 & 2005 & 2006 & 2007 \\
\hline & $\begin{array}{l}\text { Estimate } \\
\text { (p-value) }\end{array}$ & $\begin{array}{l}\text { Estimate } \\
\text { (p-value) }\end{array}$ & $\begin{array}{l}\text { Estimate } \\
\text { (p-value) }\end{array}$ & $\begin{array}{l}\text { Estimate } \\
\text { (p-value) }\end{array}$ & $\begin{array}{l}\text { Estimate } \\
\text { (p-value) }\end{array}$ & $\begin{array}{l}\text { Estimate } \\
\text { (p-value) }\end{array}$ & $\begin{array}{l}\text { Estimate } \\
\text { (p-value) }\end{array}$ & $\begin{array}{l}\text { Estimate } \\
\text { (p-value) }\end{array}$ & $\begin{array}{l}\text { Estimate } \\
\text { (p-value) }\end{array}$ & $\begin{array}{l}\text { Estimate } \\
\text { (p-value) }\end{array}$ \\
\hline Constant & $\begin{array}{c}-.262 \\
(<0.01)\end{array}$ & $\begin{array}{c}-.247 \\
(<0.01)\end{array}$ & $\begin{array}{c}-.219 \\
(<0.01)\end{array}$ & $\begin{array}{c}-.271 \\
(<0.01)\end{array}$ & $\begin{array}{c}-.308 \\
(<0.01)\end{array}$ & $\begin{array}{c}-.270 \\
(<0.01)\end{array}$ & $\begin{array}{c}-.262 \\
(<0.01)\end{array}$ & $\begin{array}{c}-.238 \\
(<0.01)\end{array}$ & $\begin{array}{c}-.243 \\
(<0.01)\end{array}$ & $\begin{array}{c}-.275 \\
(<0.01)\end{array}$ \\
\hline CUL & $\begin{array}{c}-.013 \\
(<0.01)\end{array}$ & $\begin{array}{l}-.000 \\
(.118)\end{array}$ & $\begin{array}{c}-.000 \\
(<0.01)\end{array}$ & $\begin{array}{c}-.020 \\
(<0.01)\end{array}$ & $\begin{array}{c}-.015 \\
(<0.01)\end{array}$ & $\begin{array}{c}-.015 \\
(<0.01)\end{array}$ & $\begin{array}{c}-.009 \\
(<0.01)\end{array}$ & $\begin{array}{c}-.011 \\
(<0.01)\end{array}$ & $\begin{array}{c}-.017 \\
(<0.01)\end{array}$ & $\begin{array}{c}-.016 \\
(<0.01)\end{array}$ \\
\hline SIZE & $\begin{array}{c}.012 \\
(<0.01)\end{array}$ & $\begin{array}{l}.009 \\
(.002)\end{array}$ & $\begin{array}{l}.006 \\
(.054)\end{array}$ & $\begin{array}{c}.020 \\
(<0.01)\end{array}$ & $\begin{array}{c}.024 \\
(<0.01)\end{array}$ & $\begin{array}{c}.014 \\
(<0.01)\end{array}$ & $\begin{array}{c}.007 \\
(<0.01)\end{array}$ & $\begin{array}{l}.008 \\
(<0.01)\end{array}$ & $\begin{array}{l}.011 \\
(<0.01)\end{array}$ & $\begin{array}{c}.018 \\
(<0.01)\end{array}$ \\
\hline LEV & $\begin{array}{c}.019 \\
(<0.01)\end{array}$ & $\begin{array}{c}.024 \\
(<0.01)\end{array}$ & $\begin{array}{c}.028 \\
(<0.01)\end{array}$ & $\begin{array}{c}.026 \\
(<0.01)\end{array}$ & $\begin{array}{c}.024 \\
(<0.01)\end{array}$ & $\begin{array}{c}.015 \\
(<0.01)\end{array}$ & $\begin{array}{c}.014 \\
(<0.01)\end{array}$ & $\begin{array}{c}.016 \\
(<0.01)\end{array}$ & $\begin{array}{l}.017 \\
(<0.01)\end{array}$ & $\begin{array}{c}.016 \\
(<0.01)\end{array}$ \\
\hline GWTH & $\begin{array}{c}.053 \\
(<0.01)\end{array}$ & $\begin{array}{c}.050 \\
(<0.01)\end{array}$ & $\begin{array}{c}.041 \\
(<0.01)\end{array}$ & $\begin{array}{c}.049 \\
(<0.01)\end{array}$ & $\begin{array}{c}.041 \\
(<0.01)\end{array}$ & $\begin{array}{c}.037 \\
(<0.01)\end{array}$ & $\begin{array}{c}.053 \\
(<0.01)\end{array}$ & $\begin{array}{l}.055 \\
(<0.01)\end{array}$ & $\begin{array}{l}.069 \\
(<0.01)\end{array}$ & $\begin{array}{c}.065 \\
(<0.01)\end{array}$ \\
\hline $\mathrm{CFO}$ & $\begin{array}{c}-.391 \\
(<0.01)\end{array}$ & $\begin{array}{l}-.296 \\
(<0.01)\end{array}$ & $\begin{array}{l}-.215 \\
(<0.01)\end{array}$ & $\begin{array}{c}-.334 \\
(<0.01)\end{array}$ & $\begin{array}{l}-.420 \\
(<0.01)\end{array}$ & $\begin{array}{l}-.431 \\
(<0.01)\end{array}$ & $\begin{array}{l}-.449 \\
(<0.01)\end{array}$ & $\begin{array}{c}-.463 \\
(<0.01)\end{array}$ & $\begin{array}{l}-.428 \\
(<0.01)\end{array}$ & $\begin{array}{l}-.466 \\
(<0.01)\end{array}$ \\
\hline CAP & $\begin{array}{c}.461 \\
(<0.01)\end{array}$ & $\begin{array}{c}.050 \\
(<0.01)\end{array}$ & $\begin{array}{l}.411 \\
(<0.01)\end{array}$ & $\begin{array}{c}.401 \\
(<0.01)\end{array}$ & $\begin{array}{c}.409 \\
(<0.01)\end{array}$ & $\begin{array}{c}.467 \\
(<0.01)\end{array}$ & $\begin{array}{c}.480 \\
(<0.01)\end{array}$ & $\begin{array}{c}.463 \\
(<0.01)\end{array}$ & $\begin{array}{l}.485 \\
(<0.01)\end{array}$ & $\begin{array}{c}.493 \\
(<0.01)\end{array}$ \\
\hline LOSS & $\begin{array}{c}-.140 \\
(<0.01)\end{array}$ & $\begin{array}{c}-.156 \\
(<0.01)\end{array}$ & $\begin{array}{c}-.168 \\
(<0.01)\end{array}$ & $\begin{array}{c}-.137 \\
(<0.01)\end{array}$ & $\begin{array}{c}-.135 \\
(<0.01)\end{array}$ & $\begin{array}{c}-.121 \\
(<0.01)\end{array}$ & $\begin{array}{c}-.123 \\
(<0.01)\end{array}$ & $\begin{array}{c}-.132 \\
(<0.01)\end{array}$ & $\begin{array}{c}-.137 \\
(<0.01)\end{array}$ & $\begin{array}{c}-.146 \\
(<0.01)\end{array}$ \\
\hline fixed effects & included & included & included & included & included & included & included & included & included & included \\
\hline Adj. $R^{2}$ & .416 & .354 & .320 & .373 & .412 & .469 & .472 & .443 & .451 & .460 \\
\hline $\mathbf{N}$ & 156,906 & 156,906 & 156,906 & 156,906 & 156,906 & 156,906 & 156,906 & 156,906 & 156,906 & 156,906 \\
\hline
\end{tabular}

Note: Coefficient p-values applied two-tail and based on asymptotic Z-statistic robust to hetroscedasticity and country clustering effects using the method in Rogers (1993). For clarity in presentation the coefficients on year and country dummies have not been reported.

DACCR = signed discretionary accruals. CUL $=$ ethical behaviour of firms (WEF 2008). SIZE $=$ natural logarithm of total assets in $\$$ thousands for firm $\mathrm{i}$ in year $\mathrm{t}$. $\mathbf{L E V}=$ total long-term debt/equity for firm $\mathrm{i}$ in year $\mathrm{t}$. GWTH $=$ sales growth rate, defined as the sales in year $\mathrm{t}$ minus sales in $\mathrm{t}-1$ and scaled by sales in year $\mathrm{t}$. CFO = operating cash flows for firm $\mathrm{i}$ in year $\mathrm{t}$ scaled by lagged total assets. $\mathbf{C A P}=$ non-current (fixed) assets in year $\mathrm{t} /$ Total assets in year $\mathrm{t}$. LOSS $=$ indicator variable with the value of 1 if firm i reports negative net income in the previous year and 0 otherwise. 


\subsubsection{Test results of research question six: Adoption of IFRS}

Table 5-9(i) shows that IFRS adoption explains a substantial portion (adjusted $\mathrm{R}^{2}$ ranging from 0.416 to 0.445 ) of the variation in earnings management both in the pooled and year wise specifications. The impact of IFRS adoption appears to increase earnings management. This is similar to other studies of IFRS adoption such as the reported by van Tendeloo and Vanstraelen (2005), and Lin and Paananen (2007).

Regarding the control variables, the coefficient on CFO is negative and statistically significant at $(\mathrm{p}<.01)$ level. The SIZE coefficient is positive and significant at $(\mathrm{p}<.01)$ level implying that larger firms make more income increasing DACCR choices consistent with larger firms having more ability to generate accruals. In the year-wise specifications the coefficient on LEV is positive in all the years examined and statistically significant at $(\mathrm{p}<.01)$ level. The GWTH coefficient is positive and statistically significant in the pooled model supporting at $(\mathrm{p}<0.01)$ level, the Larcker et al. (2007) hypothesis that growth firms generate more accruals. 
Table 5-9(i)

\section{Regression Analysis of discretionary accruals with adoption of IFRS (Dependent variable is signed discretionary accruals: DACCR)}

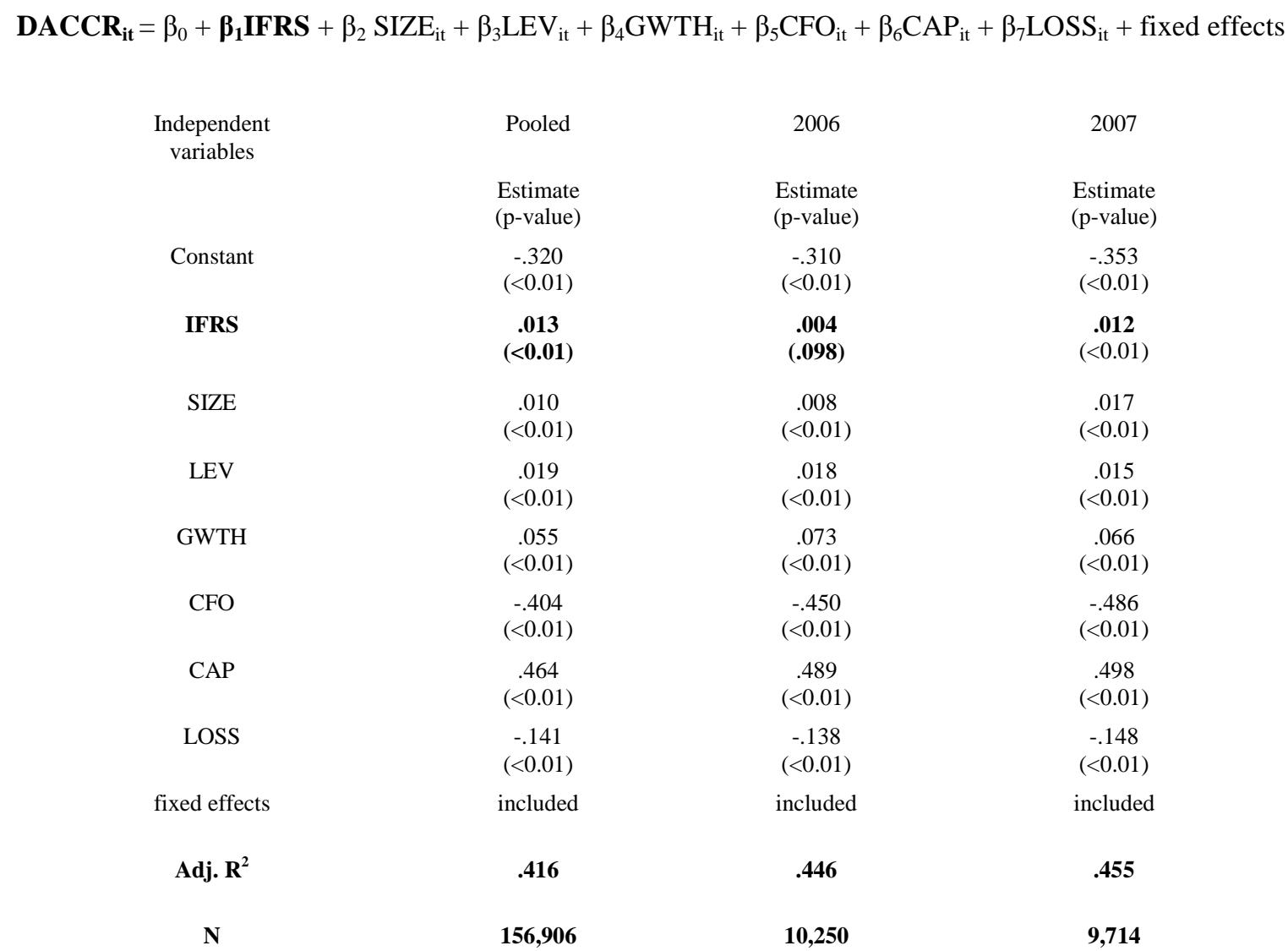

Note: Coefficient p-values applied two-tail and based on asymptotic Z-statistic robust to hetroscedasticity and country clustering effects using the method in Rogers (1993). For clarity in presentation the coefficients on year and country dummies have not been reported.

DACCR $=$ signed discretionary accruals. IFRS $=$ a dummy variable takes the value of 1 for a given year after mandatory IFRS adoption and 0 otherwise. . SIZE $=$ natural logarithm of total assets in $\$$ thousands for firm $i$ in year t. $\mathbf{L E V}=$ total long-term debt/equity for firm i in year t. GWTH = sales growth rate, defined as the sales in year t minus sales in $\mathrm{t}-1$ and scaled by sales in year t. CFO = operating cash flows for firm $\mathrm{i}$ in year $\mathrm{t}$ scaled by lagged total assets. $\mathbf{C A P}=$ non-current (fixed) assets in year $\mathrm{t} /$ Total assets in year t. LOSS $=$ indicator variable with the value of 1 if firm i reports negative net income in the previous year and 0 otherwise. 
In order to examines earnings quality as a joint function of macro governance and IFRS adoption, exploratory principal component analysis (PCA) is used to reduce the 10 macro governance variables, to a single composite variable.

Table 5-9(ii) reports on the joint effect of IFRS adoption and the macro governance. The adjusted $\mathrm{R}^{2}$ is 43.10 percent; the significance levels of individual coefficients are reported as two-tail p-values.

The macro governance variable by itself represents the effect on accruals as macro governance become stronger. The macro governance variable is significant and negatively related to DACCR at $\mathrm{p}<.01$. IFRS is significantly positively related to DACCR at $\mathrm{p}<.01$, and thus adoption of IFRS reduces earnings quality.

The interaction of macro governance with the IFRS adoption variable measures the effect of IFRS adoption on earnings quality relative to non-IFRS adopted countries as macro governance become stronger. The results show that the macro governance variables mediate the impact of IFRS adoption. The control variables are in general consistent with earlier results. 
Table 5-9(ii)

Regression analysis of discretionary accruals with IFRS adoption and macro governance (Dependent variable is signed discretionary accruals: DACCR)

DACCR $_{\text {it }}=\beta_{0}+\beta_{1}$ MACRO $+\beta_{2}$ IFRS $+\beta_{3}$ MACRO $*$ IFRS $+\beta_{4}$ SIZE $_{i t}+\beta_{5} \mathrm{LEV}_{\text {it }}+\beta_{6} \mathrm{GWTH}_{\mathrm{it}}+$ $\beta_{7} \mathrm{CFO}_{\text {it }}+\beta_{8} \mathrm{CAP}_{\mathrm{it}}+\beta_{9} \mathrm{LOSS}_{\mathrm{it}}+$ fixed effects

\begin{tabular}{|c|c|}
\hline \multirow{2}{*}{$\begin{array}{c}\text { Independent } \\
\text { variables }\end{array}$} & Pooled \\
\hline & $\begin{array}{l}\text { Estimate } \\
\text { (p-value) }\end{array}$ \\
\hline Constant & $\begin{array}{l}-.307 \\
(<0.01)\end{array}$ \\
\hline MACRO & $\begin{array}{l}-.008 \\
(<.01)\end{array}$ \\
\hline IFRS & $\begin{array}{c}.016 \\
(<0.01)\end{array}$ \\
\hline MACRO*IFRS & $\begin{array}{c}-.006 \\
(<0.01)\end{array}$ \\
\hline SIZE & $\begin{array}{c}.014 \\
(<0.01)\end{array}$ \\
\hline LEV & $\begin{array}{c}.019 \\
(<0.01)\end{array}$ \\
\hline GWTH & $\begin{array}{c}.052 \\
(<0.01)\end{array}$ \\
\hline $\mathrm{CFO}$ & $\begin{array}{l}-.421 \\
(<0.01)\end{array}$ \\
\hline CAP & $\begin{array}{c}.454 \\
(<0.01)\end{array}$ \\
\hline LOSS & $\begin{array}{l}-.132 \\
(<0.01)\end{array}$ \\
\hline fixed effects & included \\
\hline
\end{tabular}

Adj. $\mathbf{R}^{2}$

.431

$\mathbf{N}$

156,906

Note: Coefficient p-values applied two-tail and based on asymptotic Z-statistic robust to hetroscedasticity and country clustering effects using the method in Rogers (1993). For clarity in presentation the coefficients on year and country dummies have not been reported.

MACRO = macro governance are computed using PCA for 10 macro variables. IFRS $=$ A dummy variable takes the value of 1 for a given country in years after mandatory IFRS adoption and 0 otherwise. DACCR $=$ signed discretionary accruals. SIZE = natural logarithm of total assets in $\$$ thousands for firm $i$ in year t. LEV=total long-term debt/equity for firm $i$ in year t. GWTH = sales growth rate, defined as the sales in year $\mathrm{t}$ minus sales in $\mathrm{t}-1$ and scaled by sales in year $\mathrm{t}$. $\mathbf{C F O}=$ operating cash flows for firm $\mathrm{i}$ in year $\mathrm{t}$ scaled by lagged total assets. $\mathbf{C A P}=$ non-current (fixed) assets in year $\mathrm{t} /$ Total assets in year $\mathrm{t}$. LOSS = indicator variable with the value of 1 if firm i reports negative net income in the previous year and 0 otherwise. 


\subsubsection{Test results of research question seven: Initial public offerings (IPOs)}

This study extends the literature by examining whether IPOs are associated with earnings management. Table 5-1, panel C, appendix A, reports the summary statistics of IPO data by country. The table shows that, France, Hong Kong, Bahrain and China have the highest IPO proceeds as a percentage of GDP, whereas Chile, Israel and Indonesia have the lowest IPO proceeds as a percentage of GDP respectively 0.15 , 0.12 and 0.08 . Table 5-1, panel $\mathrm{D}$, appendix A, reports the there is a positive relation between country-level IPO proceeds amount as a percentage of GDP and discretionary accruals (DACCR), significant at $\mathrm{p}<.01$.

Table 5-10 reports regression results for our analysis of the relationship between IPO issue and earnings management. The IPO variable is significant at $p<.01$ in all models, both pooled and year wise specifications, and the adjusted $\mathrm{R}^{2}$ ranges from 32 percent to 47 percent. This suggests that manager make income-increasing discretionary accruals adjustments to portray a rosy picture in the year of an IPO offering to maximize the offer proceeds. However, this result should be interpreted with caution because country level IPO proceeds amount as a percentage of GDP is considered rather than firm level data. The results are thus, at best an indirect test of comparison with the studies conducted by Teoh et al. (1998) and Rangan (1998). Control variables are in general consistent with earlier results. 
Table 5-10

Regression analysis of discretionary accruals with initial public offerings (IPOs)

(Dependent variable is signed discretionary accruals: DACCR)

$\mathbf{D A C C R}_{\mathrm{it}}=\beta_{0}+\boldsymbol{\beta}_{1} \mathrm{IPO}+\beta_{2} \mathrm{SIZE}_{\mathrm{it}}+\beta_{3} \mathrm{LEV}_{\mathrm{it}}+\beta_{4} \mathrm{GWTH}_{\mathrm{it}}+\beta_{5} \mathrm{CFO}_{\mathrm{it}}+\beta_{6} \mathrm{CAP}_{\mathrm{it}}+\beta_{7} \mathrm{LOSS}_{\mathrm{it}}+$ fixed effects

\begin{tabular}{|c|c|c|c|c|c|c|c|c|c|c|}
\hline \multirow{2}{*}{$\begin{array}{l}\text { Independent } \\
\text { variables }\end{array}$} & Pooled & 1999 & 2000 & 2001 & 2002 & 2003 & 2004 & 2005 & 2006 & 2007 \\
\hline & $\begin{array}{l}\text { Estimate } \\
\text { (p-value) }\end{array}$ & $\begin{array}{l}\text { Estimate } \\
\text { (p-value) }\end{array}$ & $\begin{array}{l}\text { Estimate } \\
\text { (p-value) }\end{array}$ & $\begin{array}{l}\text { Estimate } \\
\text { (p-value) }\end{array}$ & $\begin{array}{l}\text { Estimate } \\
\text { (p-value) }\end{array}$ & $\begin{array}{l}\text { Estimate } \\
\text { (p-value) }\end{array}$ & $\begin{array}{l}\text { Estimate } \\
\text { (p-value) }\end{array}$ & $\begin{array}{l}\text { Estimate } \\
\text { (p-value) }\end{array}$ & $\begin{array}{l}\text { Estimate } \\
\text { (p-value) }\end{array}$ & $\begin{array}{l}\text { Estimate } \\
\text { (p-value) }\end{array}$ \\
\hline Constant & $\begin{array}{l}-.311 \\
(<0.01)\end{array}$ & $\begin{array}{l}-.282 \\
(<0.01)\end{array}$ & $\begin{array}{l}-.231 \\
(<0.01)\end{array}$ & $\begin{array}{l}-.324 \\
(<0.01)\end{array}$ & $\begin{array}{l}-.357 \\
(<0.01)\end{array}$ & $\begin{array}{l}-.330 \\
(<0.01)\end{array}$ & $\begin{array}{l}-.299 \\
(<0.01)\end{array}$ & $\begin{array}{l}-.283 \\
(<0.01)\end{array}$ & $\begin{array}{l}-.310 \\
(<0.01)\end{array}$ & $\begin{array}{c}-.348 \\
(<0.01)\end{array}$ \\
\hline IPO & $\underset{(<0.01)}{.004}$ & $\begin{array}{l}.005 \\
(<0.01)\end{array}$ & $\begin{array}{c}.006 \\
(<0.01)\end{array}$ & $\begin{array}{c}.007 \\
(<0.01)\end{array}$ & $\begin{array}{c}.004 \\
(<0.01)\end{array}$ & $\begin{array}{c}.004 \\
(<0.01)\end{array}$ & $\begin{array}{c}.003 \\
(<0.01)\end{array}$ & $\underset{(<0.01)}{.004}$ & $\begin{array}{c}.003 \\
(<0.01)\end{array}$ & $\begin{array}{c}.004 \\
(<0.01)\end{array}$ \\
\hline SIZE & $\begin{array}{c}.016 \\
(<0.01)\end{array}$ & $\begin{array}{c}.011 \\
(<0.01)\end{array}$ & $\begin{array}{l}.006 \\
(.053)\end{array}$ & $\begin{array}{c}.025 \\
(<0.01)\end{array}$ & $\begin{array}{c}.026 \\
(<0.01)\end{array}$ & $\begin{array}{c}.018 \\
(<0.01)\end{array}$ & $\begin{array}{c}.011 \\
(<0.01)\end{array}$ & $\begin{array}{c}.012 \\
(<0.01)\end{array}$ & $\begin{array}{c}.014 \\
(<0.01)\end{array}$ & $\begin{array}{c}.022 \\
(<0.01)\end{array}$ \\
\hline LEV & $\begin{array}{c}.019 \\
(<0.01)\end{array}$ & $\begin{array}{c}.024 \\
(<0.01)\end{array}$ & $\begin{array}{c}.028 \\
(<0.01)\end{array}$ & $\begin{array}{l}.025 \\
(<0.01)\end{array}$ & $\begin{array}{c}.023 \\
(<0.01)\end{array}$ & $\begin{array}{l}.015 \\
(<0.01)\end{array}$ & $\begin{array}{l}.014 \\
(<0.01)\end{array}$ & $\begin{array}{l}.015 \\
(<0.01)\end{array}$ & $\begin{array}{l}.017 \\
(<0.01)\end{array}$ & $\begin{array}{c}.014 \\
(<0.01)\end{array}$ \\
\hline GWTH & $\begin{array}{c}.051 \\
(<0.01)\end{array}$ & $\begin{array}{c}.049 \\
(<0.01)\end{array}$ & $\begin{array}{c}.041 \\
(<0.01)\end{array}$ & $\begin{array}{l}.047 \\
(<0.01)\end{array}$ & $\begin{array}{l}.040 \\
(<0.01)\end{array}$ & $\begin{array}{c}.035 \\
(<0.01)\end{array}$ & $\begin{array}{l}.051 \\
(<0.01)\end{array}$ & $\begin{array}{c}.053 \\
(<0.01)\end{array}$ & $\begin{array}{r}.069 \\
(<0.01)\end{array}$ & $\begin{array}{c}.062 \\
(<0.01)\end{array}$ \\
\hline $\mathrm{CFO}$ & $\begin{array}{l}-.388 \\
(<0.01)\end{array}$ & $\begin{array}{l}-.288 \\
(<0.01)\end{array}$ & $\begin{array}{l}-.205 \\
(<0.01)\end{array}$ & $\begin{array}{l}-.317 \\
(<0.01)\end{array}$ & $\begin{array}{l}-.409 \\
(<0.01)\end{array}$ & $\begin{array}{l}-.431 \\
(<0.01)\end{array}$ & $\begin{array}{l}-.452 \\
(<0.01)\end{array}$ & $\begin{array}{l}-.465 \\
(<0.01)\end{array}$ & $\begin{array}{l}-.433 \\
(<0.01)\end{array}$ & $\begin{array}{c}-.461 \\
(<0.01)\end{array}$ \\
\hline CAP & $\begin{array}{c}.449 \\
(<0.01)\end{array}$ & $\begin{array}{l}.457 \\
(<0.01)\end{array}$ & $\begin{array}{c}.403 \\
(<0.01)\end{array}$ & $\begin{array}{c}.378 \\
(<0.01)\end{array}$ & $\begin{array}{c}.395 \\
(<0.01)\end{array}$ & $\begin{array}{c}.454 \\
(<0.01)\end{array}$ & $\begin{array}{l}.468 \\
(<0.01)\end{array}$ & $\begin{array}{c}.454 \\
(<0.01)\end{array}$ & $\begin{array}{l}.480 \\
(<0.01)\end{array}$ & $\begin{array}{c}.488 \\
(<0.01)\end{array}$ \\
\hline LOSS & $\begin{array}{c}-.134 \\
(<0.01)\end{array}$ & $\begin{array}{c}-.153 \\
(<0.01)\end{array}$ & $\begin{array}{l}-.164 \\
(<0.01)\end{array}$ & $\begin{array}{l}-.123 \\
(<0.01)\end{array}$ & $\begin{array}{l}-.128 \\
(<0.01)\end{array}$ & $\begin{array}{l}-.119 \\
(<0.01)\end{array}$ & $\begin{array}{l}-.120 \\
(<0.01)\end{array}$ & $\begin{array}{l}-.129 \\
(<0.01)\end{array}$ & $\begin{array}{l}-.136 \\
(<0.01)\end{array}$ & $\begin{array}{c}-.142 \\
(<0.01)\end{array}$ \\
\hline fixed effects & included & included & included & included & included & included & included & included & included & included \\
\hline Adj. $R^{2}$ & .424 & .356 & .321 & .393 & .420 & .476 & .475 & .448 & .455 & .468 \\
\hline $\mathbf{N}$ & 156,906 & 156,906 & 156,906 & 156,906 & 156,906 & 156,906 & 156,906 & 156,906 & 156,906 & 156,906 \\
\hline
\end{tabular}

Note: Coefficient p-values applied two-tail and based on asymptotic Z-statistic robust to hetroscedasticity and country clustering effects using the method in Rogers (1993). For clarity in presentation the coefficients on year and country dummies have not been reported.

DACCR $=$ signed discretionary accruals. IPO $=$ initial public offerings $($ WEF 2008). SIZE $=$ natural logarithm of total assets in $\$$ thousands for firm $\mathrm{i}$ in year $\mathrm{t}$. $\mathbf{L E V}=$ total long-term debt/equity for firm $\mathrm{i}$ in year t. GWTH = sales growth rate, defined as the sales in year t minus sales in t-1 and scaled by sales in year t. CFO $=$ operating cash flows for firm $\mathrm{i}$ in year $\mathrm{t}$ scaled by lagged total assets. $\mathbf{C A P}=$ non-current (fixed) assets in year $\mathrm{t} /$ Total assets in year $\mathrm{t}$. LOSS $=$ indicator variable with the value of 1 if firm i reports negative net income in the previous year and 0 otherwise. 


\subsubsection{Test results of research question eight: Debt contracts}

As there is no comprehensive information available on the use of accounting information in debt covenants and collecting of actual debt covenants for the sample is not feasible earnings management was tested by regressing DACCR on long term debt to total equity after controlling for other factors known to affect DACCR. This is obviously an indirect approach, but provided DACCR is measured with minimum of noise and the debt level represents the actual outstanding obligations of the borrower, a relationship is expected between the two.

The regression results in Table 5-11 show that in the pooled and year wise specifications, DACCR and LEV are positively related. In the pooled specification LEV enters the regression with a positive and statistically significant coefficient of .018 ( $\mathrm{p}<.01$, two-tailed test). This suggests that as corporate leverage increases managers make income-increasing discretionary accruals choices to avoid costly breaches of debt contract. Regarding the control variables, coefficient on CFO is negative and statistically significant at $(\mathrm{p}<.01)$ level. The SIZE coefficient is positive and significant at $(\mathrm{p}<0.01)$ level implying that larger firms make more income increasing DACCR choices consistent with larger firms having more ability to generate accruals. The variables together explain about $45 \%$ variation in DACCR. In the year wise specifications the coefficient on LEV is positive in all the year examined and statistically significant except 2007. The GWTH coefficient is positive and statistically significant in the pooled model, except in 2000 and 2007 supporting McNichols hypothesis that growth firms generate more accruals. The yearly adjusted $\mathrm{R}^{2}$ varies from a low of $11.4 \%$ in 2005 to a high of $57.5 \%$ in 2003 . 
Table 5-11

Regression analysis of discretionary accruals with debt contracts

(Dependent variable is signed discretionary accruals: DACCR)

$\mathbf{D A C C R}_{\mathrm{it}}=\beta_{0}+\boldsymbol{\beta}_{1} \mathbf{L E V}+\beta_{2} \mathrm{SIZE}_{\mathrm{it}}+\beta_{3} \mathrm{LEV}_{\mathrm{it}}+\beta_{4} \mathrm{GWTH}_{\mathrm{it}}+\beta_{5} \mathrm{CFO}_{\mathrm{it}}+\beta_{6} \mathrm{CAP}_{\mathrm{it}}+\beta_{7}|\mathrm{TACCR}|+\beta_{7} \mathrm{LOSS}_{\mathrm{it}}+$ fixed effects

\begin{tabular}{|c|c|c|c|c|c|c|c|c|c|c|}
\hline \multirow{2}{*}{$\begin{array}{l}\text { Independent } \\
\text { variables }\end{array}$} & Pooled & 1999 & 2000 & 2001 & 2002 & 2003 & 2004 & 2005 & 2006 & 2007 \\
\hline & $\begin{array}{l}\text { Estimate } \\
\text { (p-value) }\end{array}$ & $\begin{array}{l}\text { Estimate } \\
\text { (p-value) }\end{array}$ & $\begin{array}{l}\text { Estimate } \\
\text { (p-value) }\end{array}$ & $\begin{array}{l}\text { Estimate } \\
\text { (p-value) }\end{array}$ & $\begin{array}{l}\text { Estimate } \\
\text { (p-value) }\end{array}$ & $\begin{array}{l}\text { Estimate } \\
\text { (p-value) }\end{array}$ & $\begin{array}{l}\text { Estimate } \\
\text { (p-value) }\end{array}$ & $\begin{array}{c}\text { Estimate } \\
\text { (p-value) }\end{array}$ & $\begin{array}{c}\text { Estimate } \\
\text { (p-value) }\end{array}$ & $\begin{array}{r}\text { Estimate } \\
\text { (p-value) }\end{array}$ \\
\hline Constant & $\begin{array}{l}-.317 \\
(<0.01)\end{array}$ & $\begin{array}{l}-.229 \\
(<0.01)\end{array}$ & $\begin{array}{l}-3.470 \\
(<0.01)\end{array}$ & $\begin{array}{l}-.270 \\
(<0.01)\end{array}$ & $\begin{array}{l}-.077 \\
(<0.01)\end{array}$ & $\begin{array}{l}-.155 \\
(<0.01)\end{array}$ & $\begin{array}{l}.189 \\
(<0.01)\end{array}$ & $\begin{array}{l}.160 \\
(<0.01)\end{array}$ & $\begin{array}{l}-.452 \\
(<0.01)\end{array}$ & $\begin{array}{c}.033 \\
(<0.01)\end{array}$ \\
\hline LEV & $\begin{array}{c}.018 \\
(<0.01)\end{array}$ & $\begin{array}{c}.021 \\
(<\mathbf{0 . 0 1})\end{array}$ & $\begin{array}{c}.017 \\
(.029)\end{array}$ & $\begin{array}{c}.012 \\
(<0.01)\end{array}$ & $\begin{array}{l}.005 \\
(.003)\end{array}$ & $\begin{array}{c}.016 \\
(<0.01)\end{array}$ & $\begin{array}{c}.009 \\
(<0.01)\end{array}$ & $\begin{array}{c}.009 \\
(<0.01)\end{array}$ & $\begin{array}{c}.021 \\
(<0.01)\end{array}$ & $\begin{array}{l}.0005 \\
(.394)\end{array}$ \\
\hline SIZE & $\begin{array}{c}.010 \\
(<0.01)\end{array}$ & $\begin{array}{l}.002 \\
(.554)\end{array}$ & $\begin{array}{c}.095 \\
(<0.01)\end{array}$ & $\begin{array}{l}.035 \\
(<0.01)\end{array}$ & $\begin{array}{l}.020 \\
(<0.01)\end{array}$ & $\begin{array}{l}.016 \\
(<0.01)\end{array}$ & $\begin{array}{c}.029 \\
(<0.01)\end{array}$ & $\begin{array}{c}.016 \\
(<0.01)\end{array}$ & $\begin{array}{c}.013 \\
(<0.01)\end{array}$ & $\begin{array}{c}.014 \\
(<0.01)\end{array}$ \\
\hline GWTH & $\begin{array}{c}.055 \\
(<0.01)\end{array}$ & $\begin{array}{c}.054 \\
(<0.01)\end{array}$ & $\begin{array}{l}-.010 \\
(.232)\end{array}$ & $\begin{array}{l}.010 \\
(<0.01)\end{array}$ & $\begin{array}{c}.002 \\
(.358)\end{array}$ & $\begin{array}{c}.022 \\
(<0.01)\end{array}$ & $\begin{array}{c}.014 \\
(.005)\end{array}$ & $\begin{array}{l}.030 \\
(<0.01)\end{array}$ & $\begin{array}{l}.045 \\
(<0.01)\end{array}$ & $\begin{array}{c}.000 \\
(.141)\end{array}$ \\
\hline $\mathrm{CFO}$ & $\begin{array}{l}-.418 \\
(<0.01)\end{array}$ & $\begin{array}{l}-.402 \\
(<0.01)\end{array}$ & $\begin{array}{l}-.301 \\
(<0.01)\end{array}$ & $\begin{array}{l}-2.63 \\
(<0.01)\end{array}$ & $\begin{array}{l}-.215 \\
(<0.01)\end{array}$ & $\begin{array}{l}-.299 \\
(<0.01)\end{array}$ & $\begin{array}{c}-.327 \\
(<0.01)\end{array}$ & $\begin{array}{l}-.313 \\
(<0.01)\end{array}$ & $\begin{array}{l}-.230 \\
(<0.01)\end{array}$ & $\begin{array}{c}-.274 \\
(<0.01)\end{array}$ \\
\hline CAP & $\begin{array}{c}.468 \\
(<0.01)\end{array}$ & $\begin{array}{c}.452 \\
(<0.01)\end{array}$ & $\begin{array}{l}2.530 \\
(<0.01)\end{array}$ & $\begin{array}{l}-.058 \\
(<0.01)\end{array}$ & $\begin{array}{l}-.279 \\
(<0.01)\end{array}$ & $\begin{array}{c}.745 \\
(<0.01)\end{array}$ & $\begin{array}{c}.159 \\
(<0.01)\end{array}$ & $\begin{array}{l}-.041 \\
(<0.01)\end{array}$ & $\begin{array}{l}.471 \\
(<0.01)\end{array}$ & $\begin{array}{c}-.010 \\
(<0.01)\end{array}$ \\
\hline LOSS & $\begin{array}{c}-.135 \\
(<0.01)\end{array}$ & $\begin{array}{l}-.157 \\
(<0.01)\end{array}$ & $\begin{array}{l}-.294 \\
(<0.01)\end{array}$ & $\begin{array}{l}-.146 \\
(<0.01)\end{array}$ & $\begin{array}{l}-.028 \\
(<0.01)\end{array}$ & $\begin{array}{l}-.111 \\
(<0.01)\end{array}$ & $\begin{array}{c}-.023 \\
(<0.01)\end{array}$ & $\begin{array}{l}-.073 \\
(<0.01)\end{array}$ & $\begin{array}{l}-.128 \\
(<0.01)\end{array}$ & $\begin{array}{c}-.155 \\
(<0.01)\end{array}$ \\
\hline fixed effects & included & included & included & included & included & included & included & included & included & included \\
\hline Adj. $\mathbf{R}^{2}$ & .450 & .412 & .429 & .243 & .340 & .575 & .097 & .114 & .397 & .194 \\
\hline $\mathbf{N}$ & 156,906 & 156,906 & 156,906 & 156,906 & 156,906 & 156,906 & 156,906 & 156,906 & 156,906 & 156,906 \\
\hline
\end{tabular}

Note: Coefficient p-values applied two-tail and based on asymptotic Z-statistic robust to hetroscedasticity and country clustering effects using the method in Rogers (1993). For clarity in presentation the coefficients on year and country dummies have not been reported.

DACCR = signed discretionary accruals. LEV $=$ total long-term debt/equity for firm i in year t. SIZE $=$ natural logarithm of total assets in $\$$ thousands for firm i in year $\mathrm{t}$. GWTH = sales growth rate, defined as the sales in year $\mathrm{t}$ minus sales in $\mathrm{t}-1$ and scaled by sales in year $\mathrm{t}$. CFO $=$ operating cash flows for firm $\mathrm{i}$ in year $\mathrm{t}$ scaled by lagged total assets. CAP = non-current (fixed) assets in year t / Total assets in year t. LOSS = indicator variable with the value of 1 if firm i reports negative net income in the previous year and 0 otherwise. 


\subsubsection{Test results of research question nine: Performance based compensations}

There is no aggregate information available on the use of accounting information in executive bonus plans and it is not feasible in this study to examine individual plans. The impact on earnings management is thus tested by use of an index of incentivebased compensation. This provides only indirect evidence as compared to studies such as Healy (1985); Watts and Zimmerman (1986) and Larcker et al. (2007).

Table 5-1, panel C, appendix A, provides the summary statistics of the extent of incentive-based compensation data by country. The mean extent of incentive-based compensation is 5.09. The table shows that, France, South Africa, Switzerland and Germany rank highest on incentive-based compensation (made up in larger pert of performance-based benefits such as bonus, stock, option etc.), whereas Pakistan, Nigeria, Turkey and Egypt have the lowest ranking. Table 5-1, panel D, appendix A, reports a negative relation between country-level extent of incentive-based compensation and discretionary accruals (DACCR), significant at $\mathrm{p}<.01$.

Table 5-12 shows that the BONUS variable is significant at $p<.01$ in all models, both pooled and year wise specifications, but negative. Adjusted $\mathrm{R}^{2}$ ranges from 31 to 47 percent. The results suggest that managers do not manage earnings in order to improve their incentive based compensation. However, caution in interpretation is required as country level extent of incentive-based compensation has been considered instead of firm level data. The control variables are in general consistent with earlier results. 
Table 5-12

Regression analysis of discretionary accruals with performance based compensations (BONUS) (Dependent variable is signed discretionary accruals: DACCR)

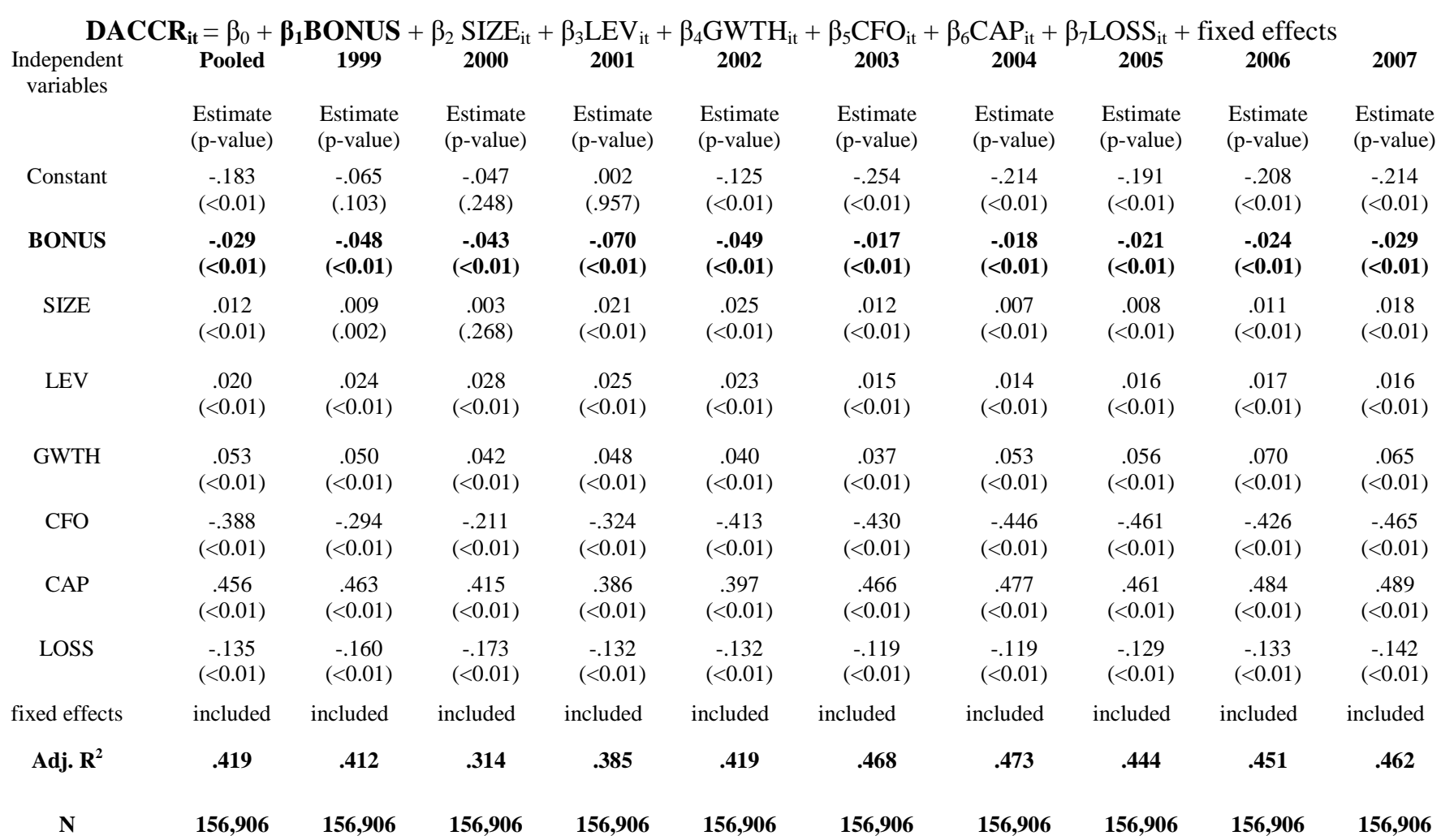

Note: Coefficient p-values applied two-tail and based on asymptotic Z-statistic robust to hetroscedasticity and country clustering effects using the method in Rogers (1993). For clarity in presentation the coefficients on year and country dummies have not been reported.

DACCR = signed discretionary accruals. BONUS = performance based compensation (WEF 2008). SIZE $=$ natural logarithm of total assets in $\$$ thousands for firm $i$ in year $t$. LEV = total long-term debt/equity for firm $i$ in year $t$. GROWTH = sales growth rate, defined as the sales in year $t$ minus sales in $t-1$ and scaled by sales in year $\mathrm{t}$. CFO $=$ operating cash flows for firm $\mathrm{i}$ in year $\mathrm{t}$ scaled by lagged total assets. $\mathbf{C A P}=$ non-current (fixed) assets in year $\mathrm{t} /$ total assets in year $\mathrm{t}$. LOSS $=$ indicator variable with the value of 1 if firm i reports negative net income in the previous year and 0 otherwise. 


\subsubsection{Test results of research question ten: Audit quality}

Table 5-1, panel B, appendix A, shows that only $54 \%$ of the firm-year observations are associated with a Big 4 auditor. Table 5-13(i) reports the regression results for BIG4 with discretionary accruals. The coefficient is negative and statistically significant in the pooled model as well as the year wise specification, except for the year 2004. The results suggest that BIG4 auditor play a vital role in shaping managers income increasing practices choices. The positive coefficient on LEV implies that firms with high leverage engage in income-increasing discretionary earnings management practices to avoid the costly breaches of debt contracts. The coefficient of GWTH is positive and statistically significant at $1 \%$ level in both pooled and yearwise specification. Since firms with growth potentials have larger accruals (McNichols 2000), it is important to control for GWTH as determinants of DACCR. The coefficient of SIZE is statistically significant at conventional level in either the pooled or year-wise specifications. CAP is positive and statistically significant at $1 \%$ level in both pooled and year-wise specification. LOSS is also significant at $1 \%$ level. 
Table 5-13(i)

Regression analysis of discretionary accruals with audit quality

(Dependent variable is signed discretionary accruals: DACCR)

$\mathbf{D A C C R}_{\text {it }}=\beta_{0}+\boldsymbol{\beta}_{\mathbf{1}} \mathbf{B I G 4}+\beta_{2} \mathrm{SIZE}_{\mathrm{it}}+\beta_{3} \mathrm{LEV}_{\mathrm{it}}+\beta_{4} \mathrm{GWTH}_{\mathrm{it}}+\beta_{5} \mathrm{CFO}_{\mathrm{it}}+\beta_{6} \mathrm{CAP}_{\mathrm{it}}+\beta_{7} \mathrm{LOSS}_{\mathrm{it}}+$ fixed effects

\begin{tabular}{|c|c|c|c|c|c|c|c|c|c|c|}
\hline \multirow{2}{*}{$\begin{array}{l}\text { Independent } \\
\text { variables }\end{array}$} & Pooled & 1999 & 2000 & 2001 & 2002 & 2003 & 2004 & 2005 & 2006 & 2007 \\
\hline & $\begin{array}{l}\text { Estimate } \\
\text { (p-value) }\end{array}$ & $\begin{array}{l}\text { Estimate } \\
\text { (p-value) }\end{array}$ & $\begin{array}{l}\text { Estimate } \\
\text { (p-value) }\end{array}$ & $\begin{array}{l}\text { Estimate } \\
\text { (p-value) }\end{array}$ & $\begin{array}{l}\text { Estimate } \\
\text { (p-value) }\end{array}$ & $\begin{array}{l}\text { Estimate } \\
\text { (p-value) }\end{array}$ & $\begin{array}{l}\text { Estimate } \\
\text { (p-value) }\end{array}$ & $\begin{array}{l}\text { Estimate } \\
\text { (p-value) }\end{array}$ & $\begin{array}{l}\text { Estimate } \\
\text { (p-value) }\end{array}$ & $\begin{array}{l}\text { Estimate } \\
\text { (p-value) }\end{array}$ \\
\hline Constant & $\begin{array}{c}-.326 \\
(<0.01)\end{array}$ & $\begin{array}{c}-.332 \\
(<0.01)\end{array}$ & $\begin{array}{c}-.294 \\
(<0.01)\end{array}$ & $\begin{array}{c}-.385 \\
(<0.01)\end{array}$ & $\begin{array}{c}-.389 \\
(<0.01)\end{array}$ & $\begin{array}{c}-.337 \\
(<0.01)\end{array}$ & $\begin{array}{c}-.296 \\
(<0.01)\end{array}$ & $\begin{array}{l}-.291 \\
(<0.01)\end{array}$ & $\begin{array}{l}-.320 \\
(<0.01)\end{array}$ & $\begin{array}{c}-.360 \\
(<0.01)\end{array}$ \\
\hline BIG4 & $\begin{array}{c}-.013 \\
(<0.01)\end{array}$ & $\begin{array}{l}-.017 \\
(.001)\end{array}$ & $\begin{array}{l}-.017 \\
(.002)\end{array}$ & $\begin{array}{c}-.024 \\
(<0.01)\end{array}$ & $\begin{array}{l}-.015 \\
(<0.01)\end{array}$ & $\begin{array}{l}-.006 \\
(.028)\end{array}$ & $\begin{array}{l}-.003 \\
(.188)\end{array}$ & $\begin{array}{l}-.008 \\
(.001)\end{array}$ & $\begin{array}{l}-.014 \\
(<0.01)\end{array}$ & $\begin{array}{c}-.016 \\
(<0.01)\end{array}$ \\
\hline SIZE & $\begin{array}{c}.013 \\
(<0.01)\end{array}$ & $\begin{array}{l}.013 \\
(<0.01)\end{array}$ & $\begin{array}{l}.008 \\
(.021)\end{array}$ & $\begin{array}{l}.026 \\
(<0.01)\end{array}$ & $\begin{array}{c}.026 \\
(<0.01)\end{array}$ & $\begin{array}{c}.013 \\
(<0.01)\end{array}$ & $\begin{array}{c}.006 \\
(<0.01)\end{array}$ & $\begin{array}{l}.008 \\
(<0.01)\end{array}$ & $\begin{array}{c}.012 \\
(<0.01)\end{array}$ & $\begin{array}{c}. \mathbf{0 2 1} \\
(<0.01)\end{array}$ \\
\hline LEV & $\begin{array}{c}.018 \\
(<0.01)\end{array}$ & $\begin{array}{l}.023 \\
(<0.01)\end{array}$ & $\begin{array}{l}.028 \\
(<0.01)\end{array}$ & $\begin{array}{l}.025 \\
(<0.01)\end{array}$ & $\begin{array}{l}.023 \\
(<0.01)\end{array}$ & $\begin{array}{c}.015 \\
(<0.01)\end{array}$ & $\begin{array}{l}.015 \\
(<0.01)\end{array}$ & $\begin{array}{l}.016 \\
(<0.01)\end{array}$ & $\begin{array}{l}.017 \\
(<0.01)\end{array}$ & $\begin{array}{c}.015 \\
(<0.01)\end{array}$ \\
\hline GWTH & $\begin{array}{c}.055 \\
(<0.01)\end{array}$ & $\begin{array}{c}.051 \\
(<0.01)\end{array}$ & $\begin{array}{c}.043 \\
(<0.01)\end{array}$ & $\begin{array}{l}.050 \\
(<0.01)\end{array}$ & $\begin{array}{c}.043 \\
(<0.01)\end{array}$ & $\begin{array}{c}.041 \\
(<0.01)\end{array}$ & $\begin{array}{c}.053 \\
(<0.01)\end{array}$ & $\begin{array}{c}.056 \\
(<0.01)\end{array}$ & $\begin{array}{c}.073 \\
(<0.01)\end{array}$ & $\begin{array}{c}.066 \\
(<0.01)\end{array}$ \\
\hline $\mathrm{CFO}$ & $\begin{array}{l}-.416 \\
(<0.01)\end{array}$ & $\begin{array}{c}-.306 \\
(<0.01)\end{array}$ & $\begin{array}{c}-.218 \\
(<0.01)\end{array}$ & $\begin{array}{c}-.339 \\
(<0.01)\end{array}$ & $\begin{array}{c}-.421 \\
(<0.01)\end{array}$ & $\begin{array}{c}-.442 \\
(<0.01)\end{array}$ & $\begin{array}{c}-.452 \\
(<0.01)\end{array}$ & $\begin{array}{c}-.468 \\
(<0.01)\end{array}$ & $\begin{array}{c}-.449 \\
(<0.01)\end{array}$ & $\begin{array}{c}-.482 \\
(<0.01)\end{array}$ \\
\hline CAP & $\begin{array}{l}.466 \\
(<0.01)\end{array}$ & $\begin{array}{l}.473 \\
(<0.01)\end{array}$ & $\begin{array}{l}.426 \\
(<0.01)\end{array}$ & $\begin{array}{l}.407 \\
(<0.01)\end{array}$ & $\begin{array}{c}.413 \\
(<0.01)\end{array}$ & $\begin{array}{c}.469 \\
(<0.01)\end{array}$ & $\begin{array}{l}.479 \\
(<0.01)\end{array}$ & $\begin{array}{l}.462 \\
(<0.01)\end{array}$ & $\begin{array}{c}.486 \\
(<0.01)\end{array}$ & $\begin{array}{c}.494 \\
(<0.01)\end{array}$ \\
\hline LOSS & $\begin{array}{c}-.135 \\
(<0.01)^{`}\end{array}$ & $\begin{array}{c}-.162 \\
(<0.01)\end{array}$ & $\begin{array}{c}-.176 \\
(<0.01)\end{array}$ & $\begin{array}{l}-.137 \\
(<0.01)\end{array}$ & $\begin{array}{c}-.133 \\
(<0.01)\end{array}$ & $\begin{array}{c}-.123 \\
(<0.01)\end{array}$ & $\begin{array}{c}-.125 \\
(<0.01)\end{array}$ & $\begin{array}{c}-.131 \\
(<0.01)\end{array}$ & $\begin{array}{c}-.138 \\
(<0.01)\end{array}$ & $\begin{array}{c}-.147 \\
(<0.01)\end{array}$ \\
\hline fixed effects & included & included & included & included & included & included & included & included & included & included \\
\hline Adj. $R^{2}$ & .451 & .350 & .312 & .379 & .415 & .468 & .467 & .438 & .447 & .455 \\
\hline $\mathbf{N}$ & 156,906 & 156,906 & 156,906 & 156,906 & 156,906 & 156,906 & 156,906 & 156,906 & 156,906 & 156,906 \\
\hline
\end{tabular}

Note: Coefficient p-values applied two-tail and based on asymptotic Z-statistic robust to hetroscedasticity and country clustering effects using the method in Rogers (1993). For clarity in presentation the coefficients on year and country dummies have not been reported.

DACCR $=$ signed discretionary accruals. BIG4 $=$ indicator variable with the value of 1 if the firm audited by one of the BIG 4 and otherwise 0. SIZE $=$ natural logarithm of total assets in $\$$ thousands for firm i in year t. $\mathbf{L E V}=$ total long-term debt/equity for firm $\mathrm{i}$ in year $\mathrm{t}$. $\mathbf{G W T H}=$ sales growth rate, defined as the sales in year $\mathrm{t}$ minus sales in $\mathrm{t}-1$ and scaled by sales in year $\mathrm{t}$. $\mathbf{C F O}=$ operating cash flows for firm $\mathrm{i}$ in year $\mathrm{t}$ scaled by lagged total assets. $\mathbf{C A P}=$ non-current (fixed) assets in year $\mathrm{t} /$ Total assets in year t. LOSS $=$ indicator variable with the value of 1 if firm i reports negative net income in the previous year and 0 otherwise. 
In order to examine earnings quality as a joint function of macro governance and audit quality by using exploratory PCA was used to reduce the 10 macro governance variables to a single composite variable.

Table 5-13(ii) reports on the joint effect of BIG4 choice and the macro governance. The adjusted $\mathrm{R}^{2}$ is 43 percent; the significance levels of individual coefficients are reported as two-tail p-values.

The macro governance variable by itself represents the effect on accruals as macro governance become stronger. The macro governance variable is significant and negatively related to DACCR at $\mathrm{p}<.01$. BIG4 is insignificantly negatively related to DACCR at $\mathrm{p}>.10$.

The interaction of macro governance with the BIG4 variable measures the effect of Big4 on earnings quality relative to non-big4 as macro governance become stronger. A negative sign indicate discretionary accruals of Big 4 firms are consistently smaller relative to the accruals of non-Big 4 clients as a country's macro governance regime becomes stronger. The control variables are in general consistent with earlier results. 
Table 5-13(ii)

Regression analysis of discretionary accruals with audit quality and macro governance (Dependent variable is signed discretionary accruals: DACCR)

DACCR $_{\text {it }}=\beta_{0}+\beta_{1}$ MACRO $+\beta_{2}$ BIG4 $+\beta_{3}$ MACRO*BIG4 $+\beta_{4} \mathrm{SIZE}_{\mathrm{it}}+\beta_{5} \mathrm{LEV}_{\mathrm{it}}+\beta_{6} \mathrm{GWTH}_{\mathrm{it}}+$ $\beta_{7} \mathrm{CFO}_{\mathrm{it}}+\beta_{8} \mathrm{CAP}_{\mathrm{it}}+\beta_{9} \mathrm{LOSS}_{\mathrm{it}}+$ fixed effects

\begin{tabular}{|c|c|}
\hline \multirow[b]{2}{*}{$\begin{array}{l}\text { Independent } \\
\text { variables }\end{array}$} & Pooled \\
\hline & $\begin{array}{l}\text { Estimate } \\
\text { (p-value) }\end{array}$ \\
\hline Constant & $\begin{array}{c}-.309 \\
(<0.01)\end{array}$ \\
\hline MACRO & $\begin{array}{c}-.005 \\
(<0.01)\end{array}$ \\
\hline BIG4 & $\begin{array}{l}-.000 \\
(.403)\end{array}$ \\
\hline MACRO*BIG4 & $\begin{array}{c}-.006 \\
(<0.01)\end{array}$ \\
\hline SIZE & $\begin{array}{c}.014 \\
(<0.01)\end{array}$ \\
\hline LEV & $\begin{array}{c}.019 \\
(<0.01)\end{array}$ \\
\hline GWTH & $\begin{array}{c}.052 \\
(<0.01)\end{array}$ \\
\hline $\mathrm{CFO}$ & $\begin{array}{c}-.420 \\
(<0.01)\end{array}$ \\
\hline CAP & $\begin{array}{c}.453 \\
(<0.01)\end{array}$ \\
\hline LOSS & $\begin{array}{c}-.132 \\
(<0.01)\end{array}$ \\
\hline fixed effects & included \\
\hline Adj. $\mathbf{R}^{2}$ & .430 \\
\hline $\mathbf{N}$ & 156,906 \\
\hline
\end{tabular}

Note: Coefficient p-values applied two-tail and based on asymptotic Z-statistic robust to hetroscedasticity and country clustering effects using the method in Rogers (1993). For clarity in presentation the coefficients on year and country dummies have not been reported.

MACRO = macro governance are computed using PCA for 10 macro variables. BIG4 $=$ Indicator variable with the value of 1 if the firm audited by one of the BIG 4 and otherwise 0 . DACCR = signed discretionary accruals. SIZE =natural logarithm of total assets in $\$$ thousands for firm i in year t. $\mathbf{L E V}=$ total long-term debt/equity for firm i in year t. GWTH $=$ sales growth rate, defined as the sales in year $\mathrm{t}$ minus sales in $\mathrm{t}-1$ and scaled by sales in year $\mathrm{t}$. $\mathbf{C F O}=$ operating cash flows for firm $\mathrm{i}$ in year $\mathrm{t}$ scaled by lagged total assets. $\mathbf{C A P}=$ non-current (fixed) assets in year $\mathrm{t} /$ Total assets in year t. LOSS $=$ indicator variable with the value of 1 if firm $\mathrm{i}$ reports negative net income in the previous year and 0 otherwise. 


\subsubsection{Test results of research question eleven: Board size}

Table 5-1, panel B, appendix A, provides the summary statistics of board size by country. The overall mean board size is 8.54 . The table shows that, Philippines, Thailand and Canada have high board size whereas Paraguay, Ecuador and Colombia have lowest mean board size.

The results in Table 5-14(i) show that there is a significant negative relationship between DACCR and board size in all models, both pooled and year wise specifications and the adjusted $\mathrm{R}^{2}$ ranges from 10 percent to 57 percent. The result suggests that the larger the board, the more effective it is in its monitoring function. This finding is consistent with the findings of Jensen (1993), Lipton and Lorsch (1992) and Larcker et al. (2007) who argue that large boards are more effective in their oversight duties relative to smaller boards and are susceptible to the CEO's domination over board matters. In contrast, Yermack's (1996) study found that smaller boards are associated with better firm performance. This is particularly true of large US (mean BOD 5.47) industrial corporations, where market values for firms with smaller boards are high. The control variables are in general consistent with earlier results. 


\section{Table 5-14(i)}

Regression analysis of discretionary accruals with board size (Dependent variable is signed discretionary accruals: DACCR)

$\mathbf{D A C C R}_{\mathrm{it}}=\beta_{0}+\beta_{1} \mathbf{B O D}+\beta_{2} \mathrm{SIZE}_{\mathrm{it}}+\beta_{3} \mathrm{LEV}_{\mathrm{it}}+\beta_{4} \mathrm{GWTH}_{\mathrm{it}}+\beta_{5} \mathrm{CFO}_{\mathrm{it}}+\beta_{6} \mathrm{CAP}_{\mathrm{it}}+\beta_{7} \mathrm{LOSS}_{\mathrm{it}}+$ fixed effects

\begin{tabular}{|c|c|c|c|c|c|c|c|c|c|c|}
\hline \multirow{2}{*}{$\begin{array}{l}\text { Independent } \\
\text { variables }\end{array}$} & Pooled & 1999 & 2000 & 2001 & 2002 & 2003 & 2004 & 2005 & 2006 & 2007 \\
\hline & $\begin{array}{l}\text { Estimate } \\
\text { (p-value) }\end{array}$ & $\begin{array}{l}\text { Estimate } \\
\text { (p-value) }\end{array}$ & $\begin{array}{l}\text { Estimate } \\
\text { (p-value) }\end{array}$ & $\begin{array}{l}\text { Estimate } \\
\text { (p-value) }\end{array}$ & $\begin{array}{l}\text { Estimate } \\
\text { (p-value) }\end{array}$ & $\begin{array}{l}\text { Estimate } \\
\text { (p-value) }\end{array}$ & $\begin{array}{l}\text { Estimate } \\
\text { (p-value) }\end{array}$ & $\begin{array}{l}\text { Estimate } \\
\text { (p-value) }\end{array}$ & $\begin{array}{l}\text { Estimate } \\
\text { (p-value) }\end{array}$ & $\begin{array}{l}\text { Estimate } \\
\text { (p-value) }\end{array}$ \\
\hline Constant & $\begin{array}{l}-.320 \\
(<0.01)\end{array}$ & $\begin{array}{l}-.478 \\
(<0.01)\end{array}$ & $\begin{array}{l}-3.448 \\
(<0.01)\end{array}$ & $\begin{array}{l}-.280 \\
(<0.01)\end{array}$ & $\begin{array}{c}-.087 \\
(<0.01)\end{array}$ & $\begin{array}{l}-.161 \\
(<0.01)\end{array}$ & $\begin{array}{l}.176 \\
(<0.01)\end{array}$ & $\begin{array}{l}.149 \\
(<0.01)\end{array}$ & $\begin{array}{c}-.434 \\
(<0.01)\end{array}$ & $\begin{array}{l}.021 \\
(.008)\end{array}$ \\
\hline BOD & $\begin{array}{c}-.000 \\
(<0.01)\end{array}$ & $\begin{array}{l}-.001 \\
(.022)\end{array}$ & $\begin{array}{c}-.003 \\
(.055)\end{array}$ & $\begin{array}{l}-.000 \\
(.086)\end{array}$ & $\begin{array}{c}-.003 \\
(<0.01)\end{array}$ & $\begin{array}{l}-.000 \\
(.167)\end{array}$ & $\begin{array}{c}-.003 \\
(<0.01)\end{array}$ & $\begin{array}{c}-.003 \\
(<0.01)\end{array}$ & $\begin{array}{c}-.001 \\
(<0.01)\end{array}$ & $\begin{array}{c}-.002 \\
(<0.01)\end{array}$ \\
\hline SIZE & $\begin{array}{c}.012 \\
(<0.01)\end{array}$ & $\begin{array}{l}-.006 \\
(.098)\end{array}$ & $\begin{array}{c}.096 \\
(<0.01)\end{array}$ & $\begin{array}{c}.038 \\
(<0.01)\end{array}$ & $\begin{array}{c}.027 \\
(<0.01)\end{array}$ & $\begin{array}{c}.017 \\
(<0.01)\end{array}$ & $\begin{array}{c}.036 \\
(<0.01)\end{array}$ & $\begin{array}{c}.022 \\
(<0.01)\end{array}$ & $\begin{array}{c}.017 \\
(<0.01)\end{array}$ & $\begin{array}{c}.019 \\
(<0.01)\end{array}$ \\
\hline LEV & $\begin{array}{l}.019 \\
(<0.01)\end{array}$ & $\begin{array}{l}.123 \\
(<0.01)\end{array}$ & $\begin{array}{l}.014 \\
(.085)\end{array}$ & $\begin{array}{l}.012 \\
(<0.01)\end{array}$ & $\begin{array}{l}.005 \\
(.003)\end{array}$ & $\begin{array}{l}.016 \\
(<0.01)\end{array}$ & $\begin{array}{c}.009 \\
(<0.01)\end{array}$ & $\begin{array}{l}.009 \\
(<0.01)\end{array}$ & $\begin{array}{c}.021 \\
(<0.01)\end{array}$ & $\begin{array}{l}.0005 \\
.(403)\end{array}$ \\
\hline GWTH & $\begin{array}{l}.055 \\
(<0.01)\end{array}$ & $\begin{array}{c}.003 \\
(.227)\end{array}$ & $\begin{array}{l}-.008 \\
(.380)\end{array}$ & $\begin{array}{l}.009 \\
(<0.01)\end{array}$ & $\begin{array}{l}.001 \\
(.766)\end{array}$ & $\begin{array}{l}.022 \\
(<0.01)\end{array}$ & $\begin{array}{l}.015 \\
(.002)\end{array}$ & $\begin{array}{c}.029 \\
(<0.01)\end{array}$ & $\begin{array}{l}.046 \\
(<0.01)\end{array}$ & $\begin{array}{c}.000 \\
(.148)\end{array}$ \\
\hline $\mathrm{CFO}$ & $\begin{array}{c}-.411 \\
(<0.01)\end{array}$ & $\begin{array}{c}-.098 \\
(<0.01)\end{array}$ & $\begin{array}{c}-.321 \\
(<0.01)\end{array}$ & $\begin{array}{c}-.284 \\
(<0.01)\end{array}$ & $\begin{array}{c}-.214 \\
(<0.01)\end{array}$ & $\begin{array}{c}-.301 \\
(<0.01)\end{array}$ & $\begin{array}{c}-.340 \\
(<0.01)\end{array}$ & $\begin{array}{c}-.313 \\
(<0.01)\end{array}$ & $\begin{array}{c}-.238 \\
(<0.01)\end{array}$ & $\begin{array}{c}-.274 \\
(<0.01)\end{array}$ \\
\hline CAP & $\begin{array}{c}.461 \\
(<0.01)\end{array}$ & $\begin{array}{l}.510 \\
(<0.01)\end{array}$ & $\begin{array}{c}2.526 \\
(<0.01)\end{array}$ & $\begin{array}{c}-.057 \\
(<0.01)\end{array}$ & $\begin{array}{c}-.286 \\
(<0.01)\end{array}$ & $\begin{array}{c}.743 \\
(<0.01)\end{array}$ & $\begin{array}{c}.154 \\
(<0.01)\end{array}$ & $\begin{array}{l}-.046 \\
(<0.01)\end{array}$ & $\begin{array}{c}.463 \\
(<0.01)\end{array}$ & $\begin{array}{c}-.011 \\
(<0.01)\end{array}$ \\
\hline LOSS & $\begin{array}{c}-.140 \\
(<0.01)\end{array}$ & $\begin{array}{c}-.130 \\
(<0.01)\end{array}$ & $\begin{array}{c}-.313 \\
(<0.01)\end{array}$ & $\begin{array}{c}-.151 \\
(<0.01)\end{array}$ & $\begin{array}{c}-.031 \\
(<0.01)\end{array}$ & $\begin{array}{c}-.111 \\
(<0.01)\end{array}$ & $\begin{array}{l}-.020 \\
(.001)\end{array}$ & $\begin{array}{c}-.071 \\
(<0.01)\end{array}$ & $\begin{array}{c}-.123 \\
(<0.01)\end{array}$ & $\begin{array}{c}-.153 \\
(<0.01)\end{array}$ \\
\hline fixed effects & included & included & included & included & included & included & included & included & included & included \\
\hline Adj. $\mathbf{R}^{2}$ & .416 & .528 & .427 & .246 & .341 & .570 & .101 & .118 & .406 & .195 \\
\hline $\mathbf{N}$ & 156,906 & 156,906 & 156,906 & 156,906 & 156,906 & 156,906 & 156,906 & 156,906 & 156,906 & 156,906 \\
\hline
\end{tabular}

Note: Coefficient p-values applied two-tail and based on asymptotic Z-statistic robust to hetroscedasticity and country clustering effects using the method in Rogers (1993). For clarity in presentation the coefficients on year and country dummies have not been reported.

DACCR $=$ signed discretionary accruals. BOD $=$ no of directors on the board of a firm. SIZE $=$ natural logarithm of total assets in $\$$ thousands for firm $\mathrm{i}$ in year $\mathrm{t}$. $\mathbf{L E V}=$ total long-term debt/equity for firm i in year t. GWTH = sales growth rate, defined as the sales in year t minus sales in t-1 and scaled by sales in year t. CFO $=$ operating cash flows for firm $\mathrm{i}$ in year $\mathrm{t}$ scaled by lagged total assets. $\mathbf{C A P}=$ non-current (fixed) assets in year $\mathrm{t} /$ Total assets in year $\mathrm{t}$. LOSS $=$ indicator variable with the value of 1 if firm i reports negative net income in the previous year and 0 otherwise. 
In order to examines earnings quality as a joint function of macro governance and board size by using exploratory PCA was used to reduce the 10 macro governance variables to a single composite variable.

Table 5-14(ii) reports on the joint effect of board size and the macro governance. The adjusted $\mathrm{R}^{2}$ is 43 percent; the significance levels of individual coefficients are reported as two-tail p-values.

The macro governance variable by itself represents the effect on accruals as macro governance become stronger. The macro governance variable is significant and negatively related to DACCR at $\mathrm{p}<.01$. However, board size is not significantly related to DACCR at $\mathrm{p}>.10$.

The interaction of macro governance with the board size variable measures the effect of larger board on earnings quality relative to smaller board as macro governance becomes stronger. A negative sign indicate discretionary accruals of larger board firms are consistently smaller relative to the accruals of smaller board firms as a country's macro governance regime becomes stronger. The control variables are in general consistent with earlier results. 
Table 5-14(ii)

Regression analysis of discretionary accruals with board size and macro governance

(Dependent variable is signed discretionary accruals: DACCR)

\begin{abstract}
DACCR $_{\text {it }}=\beta_{0}+\beta_{1}$ MACRO $+\beta_{2}$ BOD $+\beta_{3}$ MACRO $*$ BOD $+\beta_{4} \mathrm{SIZE}_{\mathrm{it}}+\beta_{5} \mathrm{LEV}_{\mathrm{it}}+\beta_{6} \mathrm{GWTH}_{\mathrm{it}}+$ $\beta_{7} \mathrm{CFO}_{\mathrm{it}}+\beta_{8} \mathrm{CAP}_{\mathrm{it}}+\beta_{9} \mathrm{LOSS}_{\mathrm{it}}+$ fixed effects
\end{abstract}

\begin{tabular}{|c|c|}
\hline \multirow{2}{*}{$\begin{array}{l}\text { Independent } \\
\text { variables }\end{array}$} & Pooled \\
\hline & $\begin{array}{l}\text { Estimate } \\
\text { (p-value) }\end{array}$ \\
\hline Constant & $\begin{array}{c}-.310 \\
(<0.01)\end{array}$ \\
\hline BOD & $\begin{array}{c}.001 \\
(.287)\end{array}$ \\
\hline MACRO & $\begin{array}{c}-.006 \\
(<0.01)\end{array}$ \\
\hline MACRO*BOD & $\begin{array}{l}-.007 \\
(.129)\end{array}$ \\
\hline SIZE & $\begin{array}{c}.014 \\
(<0.01)\end{array}$ \\
\hline LEV & $\begin{array}{c}.019 \\
(<0.01)\end{array}$ \\
\hline GWTH & $\begin{array}{c}.052 \\
(<0.01)\end{array}$ \\
\hline $\mathrm{CFO}$ & $\begin{array}{l}-.421 \\
(<0.01)\end{array}$ \\
\hline CAP & $\begin{array}{c}.453 \\
(<0.01)\end{array}$ \\
\hline LOSS & $\begin{array}{l}-.132 \\
(<0.01)\end{array}$ \\
\hline
\end{tabular}

$\mathbf{R}$

.646

Adj. $\mathbf{R}^{2}$

.430

$\mathbf{N}$

156,906

\begin{abstract}
Note: Coefficient p-values applied two-tail and based on asymptotic Z-statistic robust to hetroscedasticity and country clustering effects using the method in Rogers (1993). For clarity in presentation the coefficients on year and country dummies have not been reported.

MACRO = macro governance are computed using PCA for 10 macro variables. BOD $=$ no of directors on the board of a firm. DACCR = signed discretionary accruals. SIZE $=$ natural logarithm of total assets in $\$$ thousands for firm i in year t. LEV=total longterm debt/equity for firm i in year t. GWTH = sales growth rate, defined as the sales in year t minus sales in t 1 and scaled by sales in year t. CFO = operating cash flows for firm i in year $\mathrm{t}$ scaled by lagged total assets. $\mathbf{C A P}=$ non-current (fixed) assets in year $\mathrm{t} / \mathrm{Total}$ assets in year t. LOSS $=$ indicator variable with the value of 1 if firm i reports negative net income in the previous year and 0 otherwise.
\end{abstract}




\subsubsection{Test results of research question twelve: Board effectiveness}

Table 5-1, panel C, appendix A, provides the summary statistics of board effectiveness data by country. The table shows that, Sweden, United Kingdom, Australia and South Africa have highest board effectiveness, whereas Pakistan, China, Poland and Venezuela have the lowest board effectiveness respectively. Table 5-1, panel D, appendix A, reports a negative relation between country-level board effectiveness and discretionary accruals (DACCR), significant at $\mathrm{p}<.01$.

Table 5-15(i) reports regression results for analysis of the relationship between earnings management and board effectiveness. The board effectiveness variable is negative and significant in all models both pooled and year wise specifications. Adjusted $\mathrm{R}^{2}$ ranges from 31 percent to 47 percent. This suggests that board effectiveness plays a vital role in constraining managers' earnings management. However, this result should be interpreted with caution because country level board effectiveness scores are considered instead of firm level data, and these comparison with the results of studies such as (2002); Xie et al. (2003); Peasnell et al. (2005); Lee et al. (2007); and Larcker et al. (2007), must be made with caution. The control variables are in general consistent with earlier results. 
Table 5-15(i)

Regression analysis of discretionary accruals with board effectiveness (Dependent variable is signed discretionary accruals: DACCR)

$\mathbf{D A C C R}_{\mathrm{it}}=\beta_{0}+\beta_{1} \mathbf{B I N D}+\beta_{2} \mathrm{SIZE}_{\mathrm{it}}+\beta_{3} \mathrm{LEV}_{\mathrm{it}}+\beta_{4} \mathrm{GWTH}_{\mathrm{it}}+\beta_{5} \mathrm{CFO}_{\mathrm{it}}+\beta_{6} \mathrm{CAP}_{\mathrm{it}}+\beta_{7} \mathrm{LOSS}_{\mathrm{it}}+$ fixed effects

\begin{tabular}{|c|c|c|c|c|c|c|c|c|c|c|}
\hline Independent & Pooled & 1999 & 2000 & 2001 & 2002 & 2003 & 2004 & 2005 & 2006 & 2007 \\
\hline & $\begin{array}{l}\text { Estimate } \\
\text { (p-value) }\end{array}$ & $\begin{array}{l}\text { Estimate } \\
\text { (p-value) }\end{array}$ & $\begin{array}{l}\text { Estimate } \\
\text { (p-value) }\end{array}$ & $\begin{array}{l}\text { Estimate } \\
\text { (p-value) }\end{array}$ & $\begin{array}{l}\text { Estimate } \\
\text { (p-value) }\end{array}$ & $\begin{array}{l}\text { Estimate } \\
\text { (p-value) }\end{array}$ & $\begin{array}{l}\text { Estimate } \\
\text { (p-value) }\end{array}$ & $\begin{array}{l}\text { Estimate } \\
\text { (p-value) }\end{array}$ & $\begin{array}{l}\text { Estimate } \\
\text { (p-value) }\end{array}$ & $\begin{array}{l}\text { Estimate } \\
\text { (p-value) }\end{array}$ \\
\hline Constant & $\begin{array}{l}-.202 \\
(<0.01)\end{array}$ & $\begin{array}{l}-.219 \\
(<0.01)\end{array}$ & $\begin{array}{l}-.205 \\
(<0.01)\end{array}$ & $\begin{array}{l}-.077 \\
(<.032)\end{array}$ & $\begin{array}{l}-.188 \\
(<0.01)\end{array}$ & $\begin{array}{l}-.225 \\
(<0.01)\end{array}$ & $\begin{array}{l}-.248 \\
(<0.01)\end{array}$ & $\begin{array}{l}-.214 \\
(<0.01)\end{array}$ & $\begin{array}{l}-.207 \\
(<0.01)\end{array}$ & $\begin{array}{l}-.227 \\
(<0.01)\end{array}$ \\
\hline BIND & $\begin{array}{c}-.024 \\
(<0.01)\end{array}$ & $\begin{array}{l}-.019 \\
(.009)\end{array}$ & $\begin{array}{l}-.014 \\
(.061)\end{array}$ & $\begin{array}{l}-.055 \\
(<0.01)\end{array}$ & $\begin{array}{l}-.036 \\
(<0.01)\end{array}$ & $\begin{array}{c}-.022 \\
(<0.01)\end{array}$ & $\begin{array}{c}-.011 \\
(<0.01)\end{array}$ & $\begin{array}{c}-.015 \\
(<0.01)\end{array}$ & $\begin{array}{c}-.022 \\
(<0.01)\end{array}$ & $\begin{array}{c}-.024 \\
(<0.01)\end{array}$ \\
\hline SIZE & $\begin{array}{c}.012 \\
(<0.01)\end{array}$ & $\begin{array}{l}.009 \\
(.002)\end{array}$ & $\begin{array}{c}.003 \\
(.311)\end{array}$ & $\begin{array}{c}.021 \\
(<0.01)\end{array}$ & $\begin{array}{c}.024 \\
(<0.01)\end{array}$ & $\begin{array}{c}.013 \\
(<0.01)\end{array}$ & $\begin{array}{c}.006 \\
(<0.01)\end{array}$ & $\begin{array}{c}.007 \\
(<0.01)\end{array}$ & $\begin{array}{c}.010 \\
(<0.01)\end{array}$ & $\begin{array}{c}.017 \\
(<0.01)\end{array}$ \\
\hline LEV & $\begin{array}{c}.020 \\
(<0.01)\end{array}$ & $\begin{array}{c}.024 \\
(<0.01)\end{array}$ & $\begin{array}{c}.028 \\
(<0.01)\end{array}$ & $\begin{array}{c}.026 \\
(<0.01)\end{array}$ & $\begin{array}{c}.024 \\
(<0.01)\end{array}$ & $\begin{array}{c}.016 \\
(<0.01)\end{array}$ & $\begin{array}{c}.014 \\
(<0.01)\end{array}$ & $\begin{array}{c}.016 \\
(<0.01)\end{array}$ & $\begin{array}{c}.018 \\
(<0.01)\end{array}$ & $\begin{array}{c}.016 \\
(<0.01)\end{array}$ \\
\hline GWTH & $\begin{array}{c}.053 \\
(<0.01)\end{array}$ & $\begin{array}{c}.050 \\
(<0.01)\end{array}$ & $\begin{array}{c}.042 \\
(<0.01)\end{array}$ & $\begin{array}{c}.049 \\
(<0.01)\end{array}$ & $\begin{array}{c}.041 \\
(<0.01)\end{array}$ & $\begin{array}{c}.037 \\
(<0.01)\end{array}$ & $\begin{array}{c}.053 \\
(<0.01)\end{array}$ & $\begin{array}{c}.056 \\
(<0.01)\end{array}$ & $\begin{array}{c}.070 \\
(<0.01)\end{array}$ & $\begin{array}{c}.065 \\
(<0.01)\end{array}$ \\
\hline $\mathrm{CFO}$ & $\begin{array}{c}-.390 \\
(<0.01)\end{array}$ & $\begin{array}{c}-.295 \\
(<0.01)\end{array}$ & $\begin{array}{c}-.212 \\
(<0.01)\end{array}$ & $\begin{array}{c}-.331 \\
(<0.01)\end{array}$ & $\begin{array}{c}-.418 \\
(<0.01)\end{array}$ & $\begin{array}{c}-.430 \\
(<0.01)\end{array}$ & $\begin{array}{c}-.449 \\
(<0.01)\end{array}$ & $\begin{array}{c}-.463 \\
(<0.01)\end{array}$ & $\begin{array}{c}-.428 \\
(<0.01)\end{array}$ & $\begin{array}{c}-.465 \\
(<0.01)\end{array}$ \\
\hline CAP & $\begin{array}{c}.459 \\
(<0.01)\end{array}$ & $\begin{array}{c}.472 \\
(<0.01)\end{array}$ & $\begin{array}{c}.424 \\
(<0.01)\end{array}$ & $\begin{array}{c}.396 \\
(<0.01)\end{array}$ & $\begin{array}{c}.406 \\
(<0.01)\end{array}$ & $\begin{array}{c}.467 \\
(<0.01)\end{array}$ & $\begin{array}{c}.480 \\
(<0.01)\end{array}$ & $\begin{array}{c}.463 \\
(<0.01)\end{array}$ & $\begin{array}{c}.486 \\
(<0.01)\end{array}$ & $\begin{array}{c}.492 \\
(<0.01)\end{array}$ \\
\hline LOSS & $\begin{array}{c}-.138 \\
(<0.01)\end{array}$ & $\begin{array}{l}-.160 \\
(<0.01)\end{array}$ & $\begin{array}{l}-.175 \\
(<0.01)\end{array}$ & $\begin{array}{l}-.133 \\
(<0.01)\end{array}$ & $\begin{array}{c}-.133 \\
(<0.01)\end{array}$ & $\begin{array}{c}-.119 \\
(<0.01)\end{array}$ & $\begin{array}{c}-.122 \\
(<0.01)\end{array}$ & $\begin{array}{l}-.132 \\
(<0.01)\end{array}$ & $\begin{array}{c}-.136 \\
(<0.01)\end{array}$ & $\begin{array}{l}-.144 \\
(<0.01)\end{array}$ \\
\hline fixed effects & included & included & included & included & included & included & included & included & included & included \\
\hline Adj. $\mathbf{R}^{2}$ & .417 & .347 & .311 & .379 & .415 & .469 & .471 & .443 & .450 & .460 \\
\hline $\mathbf{N}$ & 156,906 & 156,906 & 156,906 & 156,906 & 156,906 & 156,906 & 156,906 & 156,906 & 156,906 & 156,906 \\
\hline
\end{tabular}

Note: Coefficient p-values applied two-tail and based on asymptotic Z-statistic robust to hetroscedasticity and country clustering effects using the method in Rogers (1993). For clarity in presentation the coefficients on year and country dummies have not been reported.

DACCR $=$ signed discretionary accruals. BIND $=$ board effectiveness (WEF 2008). SIZE $=$ natural logarithm of total assets in $\$$ thousands for firm $\mathrm{i}$ in year $\mathrm{t}$ $\mathbf{L E V}=$ total long-term debt/equity for firm $\mathrm{i}$ in year t. GWTH = sales growth rate, defined as the sales in year $\mathrm{t}$ minus sales in $\mathrm{t}-1$ and scaled by sales in year t. CFO $=$ operating cash flows for firm i in year $\mathrm{t}$ scaled by lagged total assets. CAP $=$ non-current (fixed) assets in year $\mathrm{t} /$ Total assets in year $\mathrm{t}$. LOSS $=$ indicator variable with the value of 1 if firm $i$ reports negative net income in the previous year and 0 otherwise. 
In order to examine earnings quality as a joint function of macro governance and board effectiveness, exploratory principal component analysis (PCA) was used to reduce the 10 macro governance variables to a single composite variable.

Table 5-15(ii) reports on the joint effect of board effectiveness and the macro governance. The adjusted $\mathrm{R}^{2}$ is 43.40 percent; the significance levels of individual coefficients are reported as two-tail p-values.

The macro governance variable by itself represents the effect on accruals as macro governance become stronger. The macro governance variable is significant and negatively related to DACCR at $\mathrm{p}<.01$. Board effectiveness is also significantly negatively related to DACCR at $\mathrm{p}<.01$.

The interaction of macro governance with the board effectiveness variable measures the effect of board effectiveness on earnings quality relative to ineffective board as macro governance becomes stronger. A negative sign indicate discretionary accruals of effective board are consistently smaller relative to the accruals of ineffective board as a country's macro governance regime becomes stronger. The control variables are in general consistent with earlier results. 
Table 5-15 (ii)

Regression analysis of discretionary accruals with board effectiveness and macro governance (Dependent variable is signed discretionary accruals: DACCR)

$$
\begin{aligned}
& \text { DACCR }_{i t}=\beta_{0}+\beta_{1} \text { MACRO }+\beta_{2} \text { BIND }+\beta_{3} \text { MACRO*BIND }+\beta_{4} \text { SIZE }_{i t}+\beta_{5} \mathrm{LEV}_{\text {it }}+\beta_{6} \mathrm{GWTH}_{\mathrm{it}}+ \\
& \beta_{7} \mathrm{CFO}_{\text {it }}+\beta_{8} \mathrm{CAP}_{\mathrm{it}}+\beta_{9} \mathrm{LOSS}_{\mathrm{it}}+\text { fixed effects }
\end{aligned}
$$

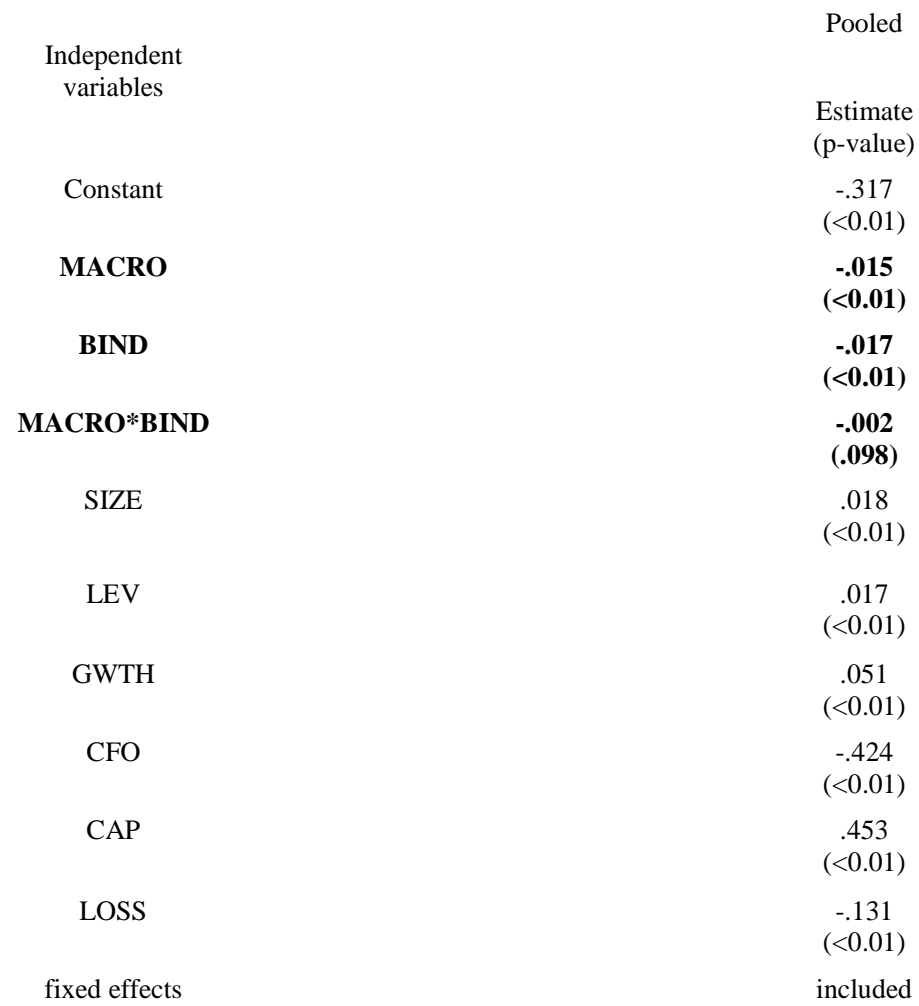

Adj. $\mathbf{R}^{2}$

.434

$\mathbf{N}$

156,906

Note: Coefficient p-values applied two-tail and based on asymptotic Z-statistic robust to hetroscedasticity and country clustering effects using the method in Rogers (1993).For clarity in presentation the coefficients on year and country dummies have not been reported.

MACRO = macro governance are computed using PCA for 10 macro variables. BIND = board effectiveness (WEF 2008). DACCR $=$ signed discretionary accruals. SIZE $=$ natural logarithm of total assets in $\$$ thousands for firm $\mathrm{i}$ in year t. LEV=total long-term debt/equity for firm $\mathrm{i}$ in year $\mathrm{t}$. GWTH $=$ sales growth rate, defined as the sales in year $\mathrm{t}$ minus sales in $\mathrm{t}-1$ and scaled by sales in year $\mathrm{t}$. $\mathbf{C F O}=$ operating cash flows for firm $\mathrm{i}$ in year $\mathrm{t}$ scaled by lagged total assets. $\mathbf{C A P}=$ non-current (fixed) assets in year $\mathrm{t} /$ Total assets in year t. LOSS = indicator variable with the value of 1 if firm i reports negative net income in the previous year and 0 otherwise. 


\subsubsection{Test results of research question thirteen: Ownership concentration}

Table 5-16(i) shows that the coefficient on OWN in both the pooled and year wise specifications is statistically significant at $(\mathrm{p}<.01)$. This result is consistent with La Porta et al. (1998) who find a high degree of ownership concentration in firms from countries with relatively poor country-level governance and argues that the conflict between large shareholders/sponsor owners and minority shareholders is the primary firm-level governance problems in such countries. In companies with concentrated ownership, controlling shareholders can expropriate wealth from minority shareholders in many ways. For example, they can extract cash by selling assets, goods or services to the company through self-dealing transactions, they can obtain loan on preferential terms, they can transfer assets from the company in focus to other companies under their control, or they can dilute the interest of minority shareholders by acquiring shares at a preferential price (Johnson et al. 2000). Morck et al. (1998) also find a positive relationship between ownership concentration and earnings management in the $5 \%$ to $25 \%$ range. The control variables are in general consistent with earlier results. 
Table 5-16(i)

Regression analysis of discretionary accruals with ownership concentration (Dependent variable is signed discretionary accruals: DACCR)

$\mathbf{D A C C R}_{\mathrm{it}}=\beta_{0}+\beta_{1} \mathbf{O W N}+\beta_{2} \mathrm{SIZE}_{\mathrm{it}}+\beta_{3} \mathrm{LEV}_{\mathrm{it}}+\beta_{4} \mathrm{GWTH}_{\mathrm{it}}+\beta_{5} \mathrm{CFO}_{\mathrm{it}}+\beta_{6} \mathrm{CAP}_{\mathrm{it}}+\beta_{7} \mathrm{LOSS}_{\mathrm{it}}+$ fixed effects

\begin{tabular}{|c|c|c|c|c|c|c|c|c|c|c|}
\hline \multirow{2}{*}{$\begin{array}{l}\text { Independent } \\
\text { variables }\end{array}$} & Pooled & 1999 & 2000 & 2001 & 2002 & 2003 & 2004 & 2005 & 2006 & 2007 \\
\hline & $\begin{array}{l}\text { Estimate } \\
\text { (p-value) }\end{array}$ & $\begin{array}{l}\text { Estimate } \\
\text { (p-value) }\end{array}$ & $\begin{array}{l}\text { Estimate } \\
\text { (p-value) }\end{array}$ & $\begin{array}{l}\text { Estimate } \\
\text { (p-value) }\end{array}$ & $\begin{array}{l}\text { Estimate } \\
\text { (p-value) }\end{array}$ & $\begin{array}{l}\text { Estimate } \\
\text { (p-value) }\end{array}$ & $\begin{array}{l}\text { Estimate } \\
\text { (p-value) }\end{array}$ & $\begin{array}{l}\text { Estimate } \\
\text { (p-value) }\end{array}$ & $\begin{array}{l}\text { Estimate } \\
\text { (p-value) }\end{array}$ & $\begin{array}{l}\text { Estimate } \\
\text { (p-value) }\end{array}$ \\
\hline Constant & $\begin{array}{c}-.369 \\
(<0.01)\end{array}$ & $\begin{array}{l}-.341 \\
(<0.01)\end{array}$ & $\begin{array}{l}-.297 \\
(<0.01)\end{array}$ & $\begin{array}{l}-.404 \\
(<0.01)\end{array}$ & $\begin{array}{l}-.405 \\
(<0.01)\end{array}$ & $\begin{array}{l}-.384 \\
(<0.01)\end{array}$ & $\begin{array}{l}-.354 \\
(<0.01)\end{array}$ & $\begin{array}{c}-.342 \\
(<0.01)\end{array}$ & $\begin{array}{c}-.359 \\
(<0.01)\end{array}$ & $\begin{array}{c}-.409 \\
(<0.01)\end{array}$ \\
\hline OWN & $\begin{array}{c}.131 \\
(<0.01)\end{array}$ & $\begin{array}{l}.162 \\
(<0.01)\end{array}$ & $\underset{(<0.01)}{.144}$ & $\begin{array}{l}.195 \\
(<0.01)\end{array}$ & $\stackrel{.120}{(<0.01)}$ & $\underset{(<0.01)}{.114}$ & $\underset{(<0.01)}{.119}$ & $\begin{array}{c}.113 \\
(<0.01)\end{array}$ & $\stackrel{.110}{(<0.01)}$ & $\stackrel{.136}{(<0.01)}$ \\
\hline SIZE & $\begin{array}{c}.014 \\
(<0.01)\end{array}$ & $\begin{array}{l}.007 \\
(.010)\end{array}$ & $\begin{array}{l}.002 \\
(.569)\end{array}$ & $\begin{array}{c}.020 \\
(<0.01)\end{array}$ & $\begin{array}{c}.023 \\
(<0.01)\end{array}$ & $\begin{array}{c}.016 \\
(<0.01)\end{array}$ & $\begin{array}{c}.011 \\
(<0.01)\end{array}$ & $\begin{array}{c}.011 \\
(<0.01)\end{array}$ & $\begin{array}{c}.012 \\
(<0.01)\end{array}$ & $\begin{array}{c}.020 \\
(<0.01)\end{array}$ \\
\hline LEV & $\begin{array}{c}.018 \\
(<0.01)\end{array}$ & $\begin{array}{c}.024 \\
(<0.01)\end{array}$ & $\begin{array}{c}.028 \\
(<0.01)\end{array}$ & $\begin{array}{c}.025 \\
(<0.01)\end{array}$ & $\begin{array}{c}.023 \\
(<0.01)\end{array}$ & $\begin{array}{c}.014 \\
(<0.01)\end{array}$ & $\begin{array}{c}.013 \\
(<0.01)\end{array}$ & $\begin{array}{c}.013 \\
(<0.01)\end{array}$ & $\begin{array}{c}.016 \\
(<0.01)\end{array}$ & $\begin{array}{c}.014 \\
(<0.01)\end{array}$ \\
\hline GWTH & $\begin{array}{c}.052 \\
(<0.01)\end{array}$ & $\begin{array}{c}.050 \\
(<0.01)\end{array}$ & $\begin{array}{c}.042 \\
(<0.01)\end{array}$ & $\begin{array}{c}.047 \\
(<0.01)\end{array}$ & $\begin{array}{c}.041 \\
(<0.01)\end{array}$ & $\begin{array}{c}.038 \\
(<0.01)\end{array}$ & $\begin{array}{c}.052 \\
(<0.01)\end{array}$ & $\begin{array}{c}.057 \\
(<0.01)\end{array}$ & $\begin{array}{c}.068 \\
(<0.01)\end{array}$ & $\begin{array}{c}.061 \\
(<0.01)\end{array}$ \\
\hline $\mathrm{CFO}$ & $\begin{array}{c}-.383 \\
(<0.01)\end{array}$ & $\begin{array}{l}-.292 \\
(<0.01)\end{array}$ & $\begin{array}{l}-.212 \\
(<0.01)\end{array}$ & $\begin{array}{l}-.311 \\
(<0.01)\end{array}$ & $\begin{array}{l}-.416 \\
(<0.01)\end{array}$ & $\begin{array}{l}-.425 \\
(<0.01)\end{array}$ & $\begin{array}{l}-. .449 \\
(<0.01)\end{array}$ & $\begin{array}{l}-.458 \\
(<0.01)\end{array}$ & $\begin{array}{c}-.421 \\
(<0.01)\end{array}$ & $\begin{array}{c}-.443 \\
(<0.01)\end{array}$ \\
\hline CAP & $\begin{array}{c}.451 \\
(<0.01)\end{array}$ & $\begin{array}{c}.457 \\
(<0.01)\end{array}$ & $\begin{array}{c}.413 \\
(<0.01)\end{array}$ & $\begin{array}{c}.383 \\
(<0.01)\end{array}$ & $\begin{array}{c}.397 \\
(<0.01)\end{array}$ & $\begin{array}{c}.458 \\
(<0.01)\end{array}$ & $\begin{array}{c}.466 \\
(<0.01)\end{array}$ & $\begin{array}{c}.455 \\
(<0.01)\end{array}$ & $\begin{array}{c}.477 \\
(<0.01)\end{array}$ & $\begin{array}{c}.488 \\
(<0.01)\end{array}$ \\
\hline LOSS & $\begin{array}{c}-.133 \\
(<0.01)\end{array}$ & $\begin{array}{l}-.158 \\
(<0.01)\end{array}$ & $\begin{array}{l}-.172 \\
(<0.01)\end{array}$ & $\begin{array}{l}-.130 \\
(<0.01)\end{array}$ & $\begin{array}{c}-.132 \\
(<0.01)\end{array}$ & $\begin{array}{l}-.118 \\
(<0.01)\end{array}$ & $\begin{array}{l}-.121 \\
(<0.01)\end{array}$ & $\begin{array}{l}-.124 \\
(<0.01)\end{array}$ & $\begin{array}{l}-.130 \\
(<0.01)\end{array}$ & $\begin{array}{c}-.132 \\
(<0.01)\end{array}$ \\
\hline fixed effects & included & included & included & included & included & included & included & included & included & included \\
\hline Adj. $\mathbf{R}^{2}$ & .424 & .353 & .317 & .389 & .417 & .475 & .480 & .451 & .452 & .468 \\
\hline $\mathbf{N}$ & 156,906 & 156,906 & 156,906 & 156,906 & 156,906 & 156,906 & 156,906 & 156,906 & 156,906 & 156,906 \\
\hline
\end{tabular}

Note: Coefficient p-values applied two-tail and based on asymptotic Z-statistic robust to hetroscedasticity and country clustering effects using the method in Rogers (1993). For clarity in presentation the coefficients on year and country dummies have not been reported.

DACCR = signed discretionary accruals. OWN = ownership concentration (La Porta et al. 2006). SIZE = natural logarithm of total assets in $\$$ thousands for firm i in year t. LEV= total long-term debt/ equity for firm i in year t. GWTH = sales growth rate, defined as the sales in year t minus sales in t- 1 and scaled by sales in year t. CFO = operating cash flows for firm i in year $\mathrm{t}$ scaled by lagged total assets. $\mathbf{C A P}=$ non-current $($ fixed) assets in year $\mathrm{t} / \mathrm{Total}$ assets in year $\mathrm{t}$. LOSS $=$ indicator variable with the value of 1 if firm i reports negative net income in the previous year and 0 otherwise. 
In conducting empirical tests such as above, it is assumed that the relationship between ownership level and earnings management behaviour is linear. However, an argument can be made that at different ranges of ownerships either a convergence-ofinterest or entrenchment effect could dominate. Morck et al. (1988) find a positive relation between ownership and firm value (proxied by Tobin's $\mathrm{Q}$ ) in the $0 \%$ to $5 \%$ board ownership range, a negative and less pronounced relation in the 5\% to $25 \%$ range, and a further positive relation beyond $25 \%$.

They interpret the findings as

.... consistent with both the convergence-of-interests and entrenchment effect. The initial rise in $Q$ as ownership rise might reflect manager's greater incentives to maximize value as their stakes rise. Beyond the 5\% ownership level, however, increase in managerial ownership may be associates with conditions conducive to the entrenchment of incumbent management.......throughout this range, the incentive effect can still be operative; it is just dominated by the entrenchment effect. As board ownership reaches the neighbourhood of 25\%, managers with even higher board ownership might not be significantly entrenched than those with 25\% ownership.... the increase in $Q$ for the very highest ownership levels then might reflect a pure convergence-of-interests effect.

McConnell and Servaes (1990) replicate Morck et al. (1998) and also find a curvilinear relation between $\mathrm{Q}$ and the fraction of common stock owned by corporate insiders. However, they find the convergence-of-interests effect to be operative up to $50 \%$ ownership stake and then the entrenchment effect comes in.

In respect of audit, Lennox (2005) investigates how divergence-of-interests and entrenchment problem affect the choice of auditor behaviour. Using a sample of 1331 listed and 538 unlisted UK companies, he finds that the relationship between management ownership and audit firm size is significantly negative when ownership is low for $0-5 \%$ but high for $25-100 \%$ which is consistent with the divergence-ofinterest effect. Consistent with the entrenchment effect, Lennox finds that the 
relationship between management ownership and audit firm size is significantly more positive when ownership is at intermediate levels.

To investigate whether the behaviour of ownership structure and earnings management takes on the functional form identified by Morck et al. (1988) a piecewise linear regression is estimated Morck's partition of ownership:

$$
\begin{array}{ll}
\text { OWN }(0-25) & =\text { actual ownership if } 0 \%<\text { OWN }<25 \% \\
\text { OWN }(25-50) & =\text { actual ownership if } 25 \%<\text { OWN }<50 \% \\
\text { OWN }(50-100) & =\text { actual ownership if 50\% }<\text { OWN }<100 \%
\end{array}
$$

Table 5-16(ii) presents the impact of ownership structure on earnings management for the pooled sample. The coefficients are statistically significant and negative for $\mathrm{OWN}<25 \%$ but positive at $\mathrm{OWN}>25 \%$. The results suggest that with higher levels of ownership, when ownership is medium range or the largest shareholders have dominance in the affairs of the companies, and management of the companies engage in income increasing earnings management strategies to maximise the personal wealth of the larger shareholders. 
Table 5-16(ii)

\section{Regression analysis of discretionary accruals with ownership concentration (Dependent variable is signed discretionary accruals: DACCR)}

DACCR $_{\text {it }}=\beta_{0}+\beta_{1}$ OWN (0-25\%)+ $\beta_{2}$ OWN (0-25\%) $+\beta_{3}$ OWN (0-25\%)+ $\beta_{4}$ SIZE $_{i t}+\beta_{5}$ LEV $_{\text {it }}+$
$\beta_{6} \mathrm{GWTH}_{\text {it }}+\beta_{7} \mathrm{CFO}_{\mathrm{it}}+\beta_{8} \mathrm{CAP}_{\mathrm{it}}+\beta_{9} \mathrm{LOSS}_{\mathrm{it}}+$ fixed effects

$\begin{array}{cc}\text { Independent variables } & \begin{array}{c}\text { Pooled } \\ \text { Estimate } \\ \text { (p-value })\end{array} \\ \text { Constant } & -.295 \\ (\mathbf{0 - 2 5}) \% & (<.01) \\ & \mathbf{- . 0 3 0} \\ \mathbf{( 2 5 - 5 0 ) \%} & (<.01) \\ \mathbf{( 5 0 - 1 0 0 ) \%} & \mathbf{. 0 1 6} \\ & (<.01) \\ \text { SIZE } & \mathbf{. 0 2 4} \\ & (<.01) \\ \text { LEV } & .014 \\ \text { GWTH } & (<.01) \\ \text { CFO } & .018 \\ \text { CAP } & (<.01) \\ & .052 \\ \text { LOSS } & (<.01) \\ & -.383 \\ \text { fixed effects } & (<.01) \\ \end{array}$

$\begin{array}{ll}\text { Adj. } \mathbf{R}^{2} & .425\end{array}$

N 156,906

Note: Coefficient p-values applied two-tail and based on asymptotic Z-statistic robust to hetroscedasticity and country clustering effects using the method in Rogers (1993). For clarity in presentation the coefficients on year and country dummies have not been reported.

DACCR = signed discretionary accruals. OWN = ownership concentration (La Porta et al. 2006). SIZE = natural logarithm of total assets in $\$$ thousands for firm i in year t. $\mathbf{L E V}=$ total long-term debt/equity for firm i in year t. GWTH $=$ sales growth rate, defined as the sales in year $\mathrm{t}$ minus sales in $\mathrm{t}-1$ and scaled by sales in year $\mathrm{t}$. $\mathbf{C F O}=$ operating cash flows for firm $\mathrm{i}$ in year $\mathrm{t}$ scaled by lagged total assets. $\mathbf{C A P}=$ non-current (fixed) assets in year $\mathrm{t} /$ Total assets in year t. LOSS = indicator variable with the value of 1 if firm i reports negative net income in the previous year and 0 otherwise. 
In order to examines earnings quality as a joint function of macro governance and ownership concentration, exploratory PCA was used to reduce the 10 macro governance variables to a single composite variable.

Table 5-16(iii) reports on the joint effect of ownership concentration and the macro governance. The adjusted $\mathrm{R}^{2}$ is 43.20 percent; the significance levels of individual coefficients are reported as two-tail p-values.

The macro governance variable by itself represents the effect on accruals as macro governance become stronger. The macro governance variable is significant and negatively related to DACCR at $\mathrm{p}<.01$. Ownership concentration is also but positively related to DACCR at $\mathrm{p}<.01$.

The interaction of macro governance with the ownership concentration variable measures the effect of high ownership concentration on earnings quality relative to low ownership concentration as macro governance becomes stronger. The results show that the higher ownership concentration mediates the impact of strong macro setting. The control variables are in general consistent with earlier results. 
Table 5-16(iii)

Regression analysis of discretionary accruals with ownership concentration and macro governance

(Dependent variable is signed discretionary accruals: DACCR)

DACCR $_{\text {it }}=\beta_{0}+\beta_{1}$ MACRO $+\beta_{2}$ OWN $+\beta_{3}$ MACRO $*$ OWN $+\beta_{4} \mathrm{SIZE}_{\mathrm{it}}+\beta_{5} \mathrm{LEV}_{\mathrm{it}}+\beta_{6} \mathrm{GWTH}_{\mathrm{it}}+$ $\beta_{7} \mathrm{CFO}_{\text {it }}+\beta_{8} \mathrm{CAP}_{\text {it }}+\beta_{9} \mathrm{LOSS}_{\text {it }}+$ fixed effects

\begin{tabular}{|c|c|}
\hline \multirow{2}{*}{ Independent variables } & Pooled \\
\hline & $\begin{array}{l}\text { Estimate } \\
\text { (p-value) }\end{array}$ \\
\hline Constant & $\begin{array}{l}-.325 \\
(<.01)\end{array}$ \\
\hline MACRO & $\begin{array}{l}-.021 \\
(<.01)\end{array}$ \\
\hline OWN & $\begin{array}{c}.025 \\
(<.01)\end{array}$ \\
\hline MACRO $*$ OWN & $\begin{array}{c}.020 \\
(<.01)\end{array}$ \\
\hline SIZE & $\begin{array}{l}.018 \\
(<.01)\end{array}$ \\
\hline LEV & $\begin{array}{l}.016 \\
(<.01)\end{array}$ \\
\hline GWTH & $\begin{array}{l}.050 \\
(<.01)\end{array}$ \\
\hline $\mathrm{CFO}$ & $\begin{array}{l}-.412 \\
(<.01)\end{array}$ \\
\hline CAP & $\begin{array}{l}.449 \\
(<.01)\end{array}$ \\
\hline LOSS & $\begin{array}{l}-.131 \\
(<.01)\end{array}$ \\
\hline fixed effects & included \\
\hline Adj. $\mathbf{R}^{2}$ & .432 \\
\hline $\mathbf{N}$ & 156,906 \\
\hline
\end{tabular}

Note: Coefficient p-values applied two-tail and based on asymptotic Z-statistic robust to hetroscedasticity and country clustering effects using the method in Rogers (1993). For clarity in presentation the coefficients on year and country dummies have not been reported.

MACRO = macro governance are computed using PCA for 10 macro variables. OWN = ownership concentration (La Porta et al. 2006). DACCR = signed discretionary accruals. SIZE = natural logarithm of total assets in $\$$ thousands for firm i in year $t$. $\mathbf{L E V}=$ total long-term debt/equity for firm $\mathrm{i}$ in year t. GWTH = sales growth rate, defined as the sales in year t minus sales in $\mathrm{t}-1$ and scaled by sales in year t. CFO = operating cash flows for firm $\mathrm{i}$ in year $\mathrm{t}$ scaled by lagged total assets. CAP $=$ non-current (fixed) assets in year $\mathrm{t} /$ Total assets in year t. LOSS = indicator variable with the value of 1 if firm i reports negative net income in the previous year and 0 otherwise. 


\subsection{Robustness tests}

A number of additional tests are performed to examine the sensitivity of the results to issues such as alternative model specifications, and deletion of small countries.

\subsubsection{Using cross-sectional Jones (1991) model}

DeFond and Jiambalvo (1994); Subramanyam (1996) and Krishnan (2003a) finds that parameter estimates in the cross-sectional Jones model are more precise than their time-series counterparts. Furthermore, Bartov et al. (2000) evaluate the ability of seven accruals estimation models in detecting earnings management by examining the association between discretionary accruals and audit qualifications and conclude that the cross-sectional Jones model and the cross sectional modified Jones model both perform better than their time-series counterparts in detecting earnings management. The important difference between the Jones model and the modified Jones model is that the modified Jones model takes into account the change in receivables in computing the change in revenues. The mean (median) values of discretionary accruals under Jones model are 0.0001 (0.0115). The difference in mean and median values are statistically significant at the $(\mathrm{p}<.01)$ level. Results of the re-estimation of all the models for macro and micro governance with discretionary accruals obtained from the Jones model are consistent with the pooled results reported in Table 5-4 to 5-16. The re-estimation results are reported in Table 5-17 to 5-18 (Appendix D). 


\subsubsection{Deleting smaller countries}

In order to assure that smaller countries with fewer observations do not drive the results, the models reported in Tables 5-4 to 5-16 were re-estimated for the sample with only the largest countries and having 200 or more firm-year observations. These additional results for the pooled specification are reported in tables 5-19 to 5-20 (Appendix D) and are unchanged from the full sample results in terms of both the sign and statistical significance on the test variables of interest. It thus appears that smaller countries do not derive the results.

The following checks were made on heteroskedasticity:

(i) The Studentized deleted residuals were plotted against 'standardized predicted values' for each regression model to check that the values for the 'Studentized deleted residuals' are evenly distributed around 'zero' for all levels of the predicted values. The scatter plots for all models showed no sign for heteroskedasticity.

(ii) The 'unstandardized residuals' of all regression models were plotted in 'histograms' and in all cases showed reasonably normal distributions.

(iii) The observed unstandardized residuals were plotted against expected normal P-P plot and the results for all models were normal.

To assess the 'goodness of fit' or 'normality test' of each model, 'unstandardized predicted values' and 'unstandardized residuals' were recorded in the data window and a scatter plot constructed by putting 'unstandardized residuals' in the Y-axis and 'unstandardized predicted values' in the X-axis. The scatter plots for all models confirmed the fit of the models and their normality. 


\subsection{Summary}

This chapter has reported the results of the tests of the thirteen research questions set out in Chapter 4. An overall summary of the results of the tests is presented in chapter 6 , the final chapter. 


\section{Chapter Six}

\section{Conclusion}

6.1 Introduction

6.2 Summary of the research findings

6.3 Implications of the study

6.4 Limitations of the study 


\subsection{Introduction}

This final chapter of the study proceeds as follows. Section 6.2 provides an overall summary of the results and Section 6.3 discusses the implications of the study for practitioners, and regulators. The chapter concludes with Section 6.4 which describes the limitations of the study.

\subsection{Summary of the research findings}

This thesis conducts a cross country study to investigate the role of macro and micro governance in mitigating opportunistic earnings management behaviour. Thirteen research questions were discussed and the results of the tests were as follows:

\section{Research question 1: Enforcement}

The results from testing research question one show that the macro governance variable enforcement is negatively associated with discretionary accruals. This is consistent with the findings of Hope et al. (2008); Francis and Wang (2008);

Daske et al. (2008); La Porta et al. (1998; 2002; and 2006); and Luez et al. (2003).

\section{Research question 2: Institutional setting}

The results indicate that a strong institutional setting at the country level reduces discretionary accruals.

\section{Research question 3: Political system}

The results suggest that political stability at the country level decreases discretionary accruals.

\section{Research question 4: Corruption}

The results suggest that discretionary accruals lower in the absence of corruption decreases. 


\section{Research question 5: Culture}

The results support the expectation that strong culture and ethical values at country level help reduce discretionary accruals.

\section{Research question 6: Adoption of IFRS}

The results suggest that adoption of IFRS leads to increased discretionary accruals. However, the macro governance setting can mitigate the impact of IFRS adoption.

\section{Research question 7: IPOs}

The results suggest that IPOs are positively related to discretionary accruals. This is consistent with managers making income-increasing discretionary accruals adjustments to portray a rosy picture in the year of offering to maximize the offer proceeds.

\section{Research question 8: Debt contracts}

The results suggest that high levels of debt are associated with higher discretionary accruals.

\section{Research question 9: Performance based compensation}

The results indicate that performance based compensation does not lead to higher discretionary accruals. However, this finding is subject to the limitations of the proxy used for performance based compensation.

\section{Research question 10: Audit quality}

The results are consistent with choice of a Big 4 auditor leading to decreased discretionary accruals. However, the interaction effect with macro governance indicates discretionary accruals of Big 4 firms are consistently smaller relative to the accruals of non-Big 4 clients as a country's macro governance regime becomes stronger. 


\section{Research question 11: Board size}

The results suggest that a larger board leads to lower discretionary accruals. However, interaction effects with macro governance result shows that discretionary accruals of larger board firms are consistently smaller relative to the accruals of smaller board firms as a country's macro governance regime becomes stronger.

\section{Research question 12: Board effectiveness}

The results indicate that an effective board is associated with lower discretionary accruals. However, interaction effects with macro governance result shows that discretionary accruals of effective board are consistently smaller relative to the accruals of ineffective board as a country's macro governance regime becomes stronger.

\section{Research question 13: Ownership concentration}

The initial results indicate that concentrated ownership increases discretionary accruals. However, further analysis indicates that this is likely to apply only at high levels of concentration.

\subsection{Implications of the study}

Evidence from the earnings management literature makes it clear that earnings management is pervasive activity. This study does not attempt to gauge the extent of earnings management. Rather it looks at the impact of the macro setting on earnings management and the micro level steps that might be taken to mitigate management tendency for earnings management. The important implication of the results of the study is that the success of any action taken to limit earnings management at the level of the company will depend on the macro setting. An 
important example is provided by IFRS. The general expectation among accounting standard setters is that adoption of IFRS will improve earnings quality. The results show the opposite. However, this is likely due to the macro setting in which IFRS is being adopted. Indeed the results of the study show that positive macro factors can mitigate the impact of adoption of IFRS.

\subsection{Limitation of the study}

The limitations of this study derive from three principal sources. Firstly, the study relies on a financial statement data base for company financial data. However, that is a common weakness for all large scale capital markets studies. The serious limitation in this study is the use of proxies for key variables. Firstly, discretionary accruals for earnings management and hence earnings quality. However, this is also a common limitation. The special limitation in this study is the proxies employed for the macro variables. The proxies are largely untested in this application and thus there is a serious risk that the results obtained may reflect choice of these proxies rather than the underlying economic reality. 


\section{List of References}

Aboody, D., Hughes, J. and Liu, J. 2005. Earnings quality, insider trading, and cost of capital. Journal of Accounting Research, 43(5): 651-673.

ADB (Asian Development Bank). 2003. Report on Bangladesh 'Capacity Building of the Securities and Exchange Commission and Selected Capital Market Institutions'. Dhaka, Bangladesh.

Ades, A. and Di Tella, R. 1997. National Champions and Corruption: Some Unpleasant Interventionist Arithmetic. The Economic Journal, 107:1023-1042.

Adiel, R. 1996. Reinsurance and the management of regulatory ratios and taxes in the property-Casualty insurance industry. Journal of Accounting and Economics, 22(1-3): 207-240.

Agrawal, A., and Knoeber, C. 1996. Firm Performance and Mechanisms to Control Agency Problems between Managers and Shareholders. Journal of Financial and Quantitative Analysis, 31(3): 377-397.

Alam, M. 1995. A theory of limits on corruption and some applications. Kyklos, 48: 419-435.

Albrecht, W. D., and Richardson, F. M. 1990. Income Smoothing by economy sector. Journal of Business Finance and Accounting, 17: 713-730.

Ali, A., and Hwang, L. 2000. Country-specific factors related to financial reporting and the value relevance of accounting data. Journal of Accounting Research, 38 (1): 1-21.

Ali, A., Hwang, L. 1995. Accrual management and the incremental information content of earnings and cash flow from operations. Working paper, Stern School of Business, New York University.

Alvarez, M., Cheibub, J. A., Limongi, F., Przeworski, A. 1996. Classifying political regimes. Studies in Comparative International Development, 31 (2): 3 36.

Anderson, R., and Rebb, D. 2004. Board composition: Balancing family influence in S\&P 500 firms. Administrative Science Quarterly, 49: 209-237.

Anderson, R., and Rebb, D. 2003a. Founding Family ownership and firm performance. Journal of Finance, 58:1301-1328.

Anderson, R., and Rebb, D. 2003b. Family ownership, corporate diversification, and firm leverage. Journal of Law and Economics, 46: 653-684.

Anderson, R., Mansi, S. and Rebb, D. 2003. Founding Family ownership and the agency cost of debt. Journal of Financial Economics, 68: 263-286. 
Aoki, M. 1988. Information, Incentives and Bargaining in the Japanese Economy. Cambridge University Press, New York, Cambridge.

Armstrong, C. S., M. E. Barth, E. J. Riedl. 2010. Market Reaction to the Adoption of IFRS in Europe. The Accounting Review, 85 (1):31-61.

Ashari, N., Hain, C. H., Soh, L. T., and Wei, H. W. 1994. Factors affecting income smoothing among listed companies in Singapore. Accounting and Business Research, 24(96): 291-301.

Asthana, S. C., and Zhang, Y. 2006. The effects of R\&D investments on persistence of abnormal earnings. Review of Accounting \& Finance, 5(2):124-139.

Ashton, D., Dunmore, P. And Tippett, M. 2004. Double Entry Bookkeeping and the Distributional Properties of Financial Ratios. Journal of Business Finance and Accounting, 31 (5\&6): 15-37.

Ataullah, A., A. Higson and Tippett, M. 2007. The distributional Properties of the Debt to Equity Ratio: Some Implications for Empirical Research. Abacus, 43(2):111-135.

Averitt, R.T. 1968. The Dual Economy: The Dynamics of American Industry Structure, Norton \& Company Inc. USA.

Ayres, F. 1994. Perceptions of Earnings Quality: What Managers Need to Know, Management Accounting, March: 27-29.

Bacon, J., and Brown, J.K. 1975. Corporate Directorship Practices: Role, Selection and Legal Status of the Board. The Conference Board, Inc., New York.

Bae, K., Tan, H. and Welker, M. 2008. International GAAP Differences: The Impact of Foreign Analysts. The Accounting Review, 83(3): 593-628.

Ball, R. J., and Brown, P. 1968. An empirical evaluation of accounting income numbers. Journal of Accounting Research, 6: 159-178.

Ball, R. 2001. Infrastructure requirements for an economically efficient system of public financial reporting and disclosure. Brookings-Wharton Papers on Financial Services: 127-182.

Ball, R., Kothari, S. and Robin, A. 2000. The Effect of International Institutional Factors on Properties of Accounting Earnings. Journal of Accounting and Economics, 29: 1-51.

Ball, R., Robin, A. and Wu, J. S. 2003. Incentives versus standards: properties of accounting income in four East Asian countries, and implications for acceptance of IAS. Journal of Accounting and Economics, 36(1-3): 235-270.

Barth, M., Landsman, W. and Lang, M. 2008. International Accounting Standards and Accounting Quality. Journal of Accounting Research, 46(3): 467-498. 
Barth, M., Beaver, W., and Landsman, W. 2001a. The Relevance of the Value Relevance Literature for Financial Accounting Standard Setting: Another View. Journal of Accounting \& Economics, 31(31): 77-104.

Barth, M., Cram, D., and Nelson, K. 2001b. Accruals and the prediction of future cash flows. Accounting Review, 76(1): 27-59.

Barth, M. E., Elliott, J. A. and Finn. M. W. 1999. Market rewards associated with patterns of increasing earnings. Journal of Accounting Research, 37 (autumn): 387-413.

Bartov, E., Gul, F. A. and Tsui, J. S. L. 2001. Discretionary-accruals models and audit qualifications. Journal of Accounting and Economics, 30(3): 421- 453.

Bartov, E., Givoly, D. and Hayn, C. 2002. The rewards to meeting or beating earnings expectations. Journal of Accounting and Economics, 33: 173-204.

Barua, A., Legoria, J., and Moffitt, J. S. 2006. Accruals Management to Achieve Earnings Benchmarks: A Comparison of Pre-Managed Profit and Loss Firms. Journal of Business Finance \& Accounting, 33(5-6): 653-670.

Bathke, A. W., and Lorek, J., and K. S. 1989. Firm-size and the predictive ability of quarterly earnings data. The Accounting Review, 64: 49-68.

Beasley, M. 1996. An Empirical Analysis of the Relation between the Board of Director Composition and Financial Statement Fraud. The Accounting Review, 71(4): 443-465.

Beatty, A., Chamberlain, S., and Magliolo, J. 1995. Managing financial reports of commercial banks: The influence of taxes, regulatory capital, and earnings. Journal of Accounting Research, 33: 231-261.

Beaver, W. H. 1968.The information content of annual earnings announcements. Journal of Accounting Research, 6: 67-92.

Beaver, W. H., and Engel, E. E. 1996. Discretionary behaviour with respect to allowances for loan losses and the behaviour of security prices. Journal of Accounting and Economics, 22(1-3): 73-95.

Beaver, W., and McNichols, M. 1998. The Characteristics and Valuation of Loss Reserves of Property Casualty Insurers. Review of Accounting Studies, 3(1-2): 7395.

Beck, T., and Levine, R. 2005. Legal Institutions and Financial Development. World Bank Policy Research working Paper Series No. 3136. The World Bank.

Beck, E. M., Horan, P. M. and Tolbert, C. M. 1978. Satisfaction in a Dual economy: A sectoral model of earnings determination. American Sociological Review, 43: 704-720. 
Becker, C. L., DeFond, M. L., Jiambalvo, J. and Subramanyam, K. R. 1998. The effect of audit quality on earnings management. Contemporary Accounting Research, 15(1): 1-24.

Bedard, J., Chtourou, S.M., Courteau, L. 2004. The effect of audit committee expertise, independence and activity on aggressive earnings management. Auditing: A journal of Practice and Theory, 23(2): 13-35.

Belkaoui, A. and Picur, R. D. 1984. The smoothing of income numbers: some empirical evidence on systematic differences between Core and Periphery industrial sectors. Journal of Business Finance \& Accounting, 11: 527-545.

Belkaoui, R., and AlNajjar. 2006. Earnings opacity internationally and elements of social, economic and accounting order. Review of Accounting and Finance, 5(3): 189-203.

Beneish, M. 1997. Detecting GAAP violation: Implications for assessing earnings management among firms with extreme financial performance. Journal of Accounting and Public Policy, 16: 271-309.

Beneish, M. 2001. Earnings management: A perspective. Managerial Finance, 27(12): 3-1.

Beneish, M. D. 1999. The detection of earnings manipulation. Financial Analysts Journal, 55: 24-36.

Beneish, M. D. and M. E. Vargus. 2002. Insider trading, earnings quality, and accrual mispricing. The Accounting Review, 77(4): 755-791.

Beny, L. N. 2005. Do insider trading laws matter? Some preliminary comparative evidence. American Law and Economics Review, 7(1): 144-183.

Berle, A. A., and Means, G. C. 1932. The Modern Corporation and Private Property. Commerce Clearing House, New York.

Bernard, V., Skinner, D. 1996. What motivates managers' choice of discretionary accruals? Journal of Accounting and Economics, 22: 313-325.

Bhagat, S., and Jefferris, R. 2002. The Econometrics of Corporate Governance Studies. MIT Press, Boston, MA.

Bhattacharya, U., Daouk, H. and Welker, M. 2003. The World Price of Earnings Opacity. The Accounting Review, 78 (3): 641-678.

Bloomfield, D., and Shackman, J. 2008. Non audit service fees, auditor characteristics and earnings restatements. Managerial Auditing Journal, 23(2): 125-141. 
Bluestone, B., Murphy, M. W., and Stevenson, M. 1973. Low wages and the working poor. The Institute of Labour and Industrial Relations. The University of Michigan-Wayne State University.

Bowen, R., Burghstahler, D., and Daley, L. 1987. The Incremental Information Content of Accrual versus Cash Flows. The Accounting Review, 3: 723-747.

Bowen, R., Rajgopal, S., and Venkatachalam, M. 2008. Accounting Discretion, Corporate Governance and Firm Performance. Contemporary Accounting Research, 25 (2):351-405.

Bowen, J., Lacey, R., and Noreen, E. 1981. Determinants of corporate decision to capitalize interest. Journal of Accounting and Economics, (August): 151-179.

Bowman, R. G., and Navissi, f. 2003. Earnings management and abnormal returns: Evidence from the 1970-1972 price control regulations. Accounting and Finance, 43(1): 1-19.

Brown, L. D. 2001. A temporal analysis of earnings surprises: Profits vs. losses. Journal of Accounting Research, 39(2): 221-241.

Brennan, M. J. and E. S. Schwartz. 1985. Evaluating Natural Resource Investments. Journal of Business, Bowen 58(2): 135-157

Brown, L. D., and Higgins, H. N. 2001. Managing earnings surprises in the US versus 12 other countries. Journal of Accounting \& Public Policy, 20: 371-398.

Burgstahler, D., Hail, L., and Leuz, C. 2007. The importance of reporting incentives: earnings management in European private and public firms. The Accounting Review, 81(5): 983-1016.

Burgstahler, D., and Eames, M. 2006. Management of earnings and analysts forecasts. Journal of Business Finance and Accounting, 33(5-6): 633-652.

Burgstahler, D., and Dichev, I. 1997. Earnings management to avoid earnings decreases and losses. Journal of Accounting and Economics, 24(1): 99-126.

Burilovich, L., and Kattelus, S. 1997. Auditors' Influence on Earnings Management: Evidence from the Alternative Minimum Tax. Journal of Applied Business Research, 13(spring): 9-22.

Bushman, R.M., Piptroski, J. D., and Smith, A. J. 2004. What Determine Corporate Transparency? Journal of Accounting Research, 42 (2): 207-252.

Bushman, R.M., and Smith, A.J. 2003. Transparency, financial accounting information, and corporate governance. Economic Policy Review, 9(1): 65-87.

Bushman, R.M., and Piotroski, J.2006. Financial Reporting Incentives for conservative accounting: The influence of legal and political institutions. Journal of Accounting \& Economics, 42(1-2): 107-148. 
Bushee, B. 1998. The influence of institutional Investors on myopic R \& D investment behaviour. The Accounting Review, 73: 305-333.

Cai, L., Rahman, A. and Courtenay, S. 2008. The effect of IFRS and its Enforcement on Earnings Management: An International Comparison. Working Paper, Massey University, New Zealand.

Caramanis, C., and Lennox, C. 2008. Audit effort and earnings management. Journal of Accounting \& Economics, 45: 116-138.

Cahan, S. 1992. The effect of antitrust investigations on discretionary accruals: A refined test of the political cost hypothesis. The Accounting Review, 67: 77-95.

Chambers, D. J. 1999. Earnings management and capital market misallocation. Working paper, University of Illinois at Urbana-Champaign.

Chen, K. Y., Lin, K. and Zhou, J. 2005. Audit quality and earnings management for Taiwan IPO firms. Managerial auditing Journal, 20(1): 86-104.

Cheng, C., Liu, C., and Schaefer, T. 1996. Earnings Permanence and the Incremental Information Content of Cash Flows from Operations. Journal of Accounting Research, 34 (spring): 175-181.

Cheng, C., Liu, C., and Schaefer, T. 1997. Accounting Accruals and the Incremental Information Content of Earnings and Cash Flows from Operations, Advances in Accounting Research, 15: 101-123.

Chtourou, S., Bedard, J., and Courteau, L. 2001. Corporate governance and earnings Management. Retrieve at http://papers. ssrn.com/abstract=275053.

Chung, R., Firth, M. and Kim, J. 2002. Institutional monitoring and opportunistic earnings management. Journal of Corporate Finance, 8: 29-48.

Chia, Y. M., Irvine, L. and Hing-wah, L. 2007. Choice of auditors and earnings management during the Asian financial crises. Managerial Auditing Journal, 22(2): 177-196.

Christie, A., and Zimmerman, J. 1994. Efficient versus Opportunistic Choices of Accounting Procedures: Corporate Control Contests. The Accounting Review, 69: 539-566.

Claessens, S., Djankov, S., Fan, J. P. H., and Lang, L. H. P. 2000a. The separation of ownership and control in East Asian corporations. Journal of Financial Economics, 58(1-2): 81-112.

Claessens, S., Djankov, S., Fan, J. P. H., and Lang, L. H. P. 2000b. Expropriation of minority shareholders: Evidence from East Asian corporations. Working paper, The World Bank, Washington, DC 
Claessens, S., and Fan, J. P. H. 2003. Corporate Governance in Asia: A survey. International Review of Finance, 3(2): 71-104.

Collins, J. H., Shackelford, D.A. and Wahlen, J.M. 1995. Bank differences in the coordination of regulatory capital, earnings and taxes. Journal of Accounting Research, 33(2): 263-291.

Collins, D., and Hribar, P. 2002. Errors in estimating accruals: implications for empirical research. Journal of Accounting Research, 40(1): 105-135.

Collingwood, H. 2001. The earnings game: Everybody plays, nobody wins. Harvard business Review, 79 (6): 65-74.

Collins, D., S. Kothari. 1989. An analysis of inter temporal and cross-sectional determinants of earnings response coefficients. Journal of Accounting and Economics, 11: 143-182.

Core, J., and W. Guay. 1999. The use of equity grants to manage optimal equity incentive levels. Journal of Accounting and Economics, 28(2): 151-184.

Core, J. E., Guay, W.R. and Larcker, D. F. 2003. Executive equity compensation and incentives: A survey. Economic Policy Review, 9 (1): 27-50.

Davidson, S., Stickney, C., and Weil, R. 1987. Accounting: The Language of Business, Seventh edition, Thomas Horton and Daughter, Arizona.

Daniels, R. 1995. The role of debt in interactive corporate governance. California Law Review, 83:1073-1113.

Daske, H., Hail, L., Leuz, C., and Verdi, R. 2009. Mandatory IFRS adoption around the world: Early Evidence on the Economic Consequences. Journal of Accounting Research, 46(5): 1085- 1142.

DeAngelo, L., 1986. Accounting numbers as market valuation substitutes: A study of management buyouts of public stockholders. The Accounting Review, 41: 400420.

DeAngelo, L.1988. Managerial competition, information costs and corporate governance: The use of accounting performance measures in proxy contest. Journal of Accounting and Economics, (January): 3-36.

DeAngelo, L. 1981. Auditor size and audit quality. Journal of Accounting and Economics, 3: 183-199.

DeAngelo, H., and Gilson, S. 1994. The Collapse of First Executive Corporation: Junk Bonds, Adverse Publicity, and the 'Run on the Bank' Phenomenon. Journal of Financial Economics, 36: 287-336. 
DeAngelo, H., Linda, E.D. and Skinner, D.J.1996. Reversal of fortune: Dividend signaling and the disappearance of sustained earnings growth. Journal of Financial Economics, 4(3): 341-373

Dechow, P.M., S.A. Richardson and I. Tuna 2003. Why are earnings Kinky? An examination of the earnings management explanation. Review of Accounting Studies, 8: 355-384.

Dechow, P. 1994. Accounting earnings and cash flows as measures of firm performance: The role of accounting accruals. Journal of Accounting and Economics, 18: 3-42.

Dedman, E. 2000. An investigation into the determinants of UK board structure before and after Cadbury. Corporate Governance, 8:133-153.

DeFond, M. L., and Jiambalvo, J. 1994. Debt covenant effects and the manipulation of accruals. Journal of accounting and Economics, 17: 145-176.

DeFond, M., and Jiambalvo, J. 1993. Factors related to auditor-client disagreements over income increasing accounting methods. Contemporary Accounting Research, 9: 411-431.

DeFond, M., and Jiambalvo, J. 1991. Incidence and Circumstances of Accounting Errors. The Accounting Review, (July): 643-655.

DeFond, M., Subramanyam, K. 1998. Auditor Changes and Discretionary Accruals. Journal of Accounting and Economics, 25: 35-68.

De Fond, M., and Hung, M. Y. 2004. Investor Protection and Corporate Governance: Evidence from Worldwide CEO Turnover. Journal of Accounting Research, 42: 269-312.

Defond, M. L., and Hung, M. 2003. An empirical analysis of analysts' cash flow forecasts. Journal of Accounting and Economics, 35(1): 73-100.

Dechow, P. M., and D. J. Skinner. 2000. Earnings management: Reconciling the views of accounting academics, practitioners, and regulators. Accounting Horizon, 14(2): 235-250.

Dechow, P. M., and Dichev, I. 2002. The quality of accruals and earnings: The role of accruals estimation errors. The Accounting Review, 77(supplement): 35-59.

Dechow, P. M., Sloan, R. G., and Sweeney, A. P. 1995. Detecting earnings management. The Accounting Review, 70(2): 193-225.

Dechow, P., Sloan, R. G., and Sweeney, A. P. 1996. Causes and Consequences of Earnings Manipulation: An Analysis of Firms Subject to Enforcement Actions by the SEC. Contemporary Accounting Research, 13:1-36. 
Dechow, P., and Sloan, R. 1991. Executive incentives and the horizon problem: An empirical investigation. Journal of Accounting and Economics, 14: 51-89.

DeGeorge, F., J. Patel and R. Zeckhauser. 1999. Earnings management to exceed thresholds. Journal of Business, 72(1): 1-33.

Deloitte's IAS Plus Website. 2009. Use of IFRSs by Jurisdiction. Retrieved June1, 2009, from http://www.iasplus.com/country/useias.htm

Demsetz, H. and K. Lehn. 1985. The structure of corporate ownership: Causes and consequences. Journal of Political Economy, 93(6): 155-1177.

DeMarzo, P. M., Fishman, M. J., and Hagerty, K. M. 1998. The optimal enforcement of insider trading regulations. Journal of Political Economy, 106(3): 602-633.

Denis, D. J., and Denis, D. K. 1994. Majority Owner-managers and Organizational Efficiency. Journal of Corporate Finance, 1: 91-118.

Dhaliwal, D. S. 1988. The Effect of the Firms' Business Risk on the Choice of Accounting Methods. Journal of Business Finance and Accounting, 15(2): 289302.

Dichev, I., and Tang, W. 2005. Matching and Volatility of Earnings. Working Paper, University of Michigan.

Dickson, P. 1998. Standard-setter bans 'big-bath' accounting. The Accountant, November 1.

Ding, Y., Hope, O. K., Jeanjean, T., and Stolowy, H. 2007. Differences between domestic accounting standards and IAS: measurement, determinants and implications. Journal of Accounting and Public Policy, 26(1): 1-38.

DiRienzo, C., Das, J., Cord, K., and Burbridge, J. 2007. Corruption and the role of Information. Journal of International Business, 38(2): 320-332.

Dixit, A., and Pindyck, R. S. 1994. Investment under Uncertainty, Princeton University Press, USA.

Doupnik, T.S., and Taskumis, G.T. 2004. A critical review of test of Gray's theory of culture relevance and suggestions for future research. Journal of Accounting Literature, 23: 1-48.

DuCharme, L., Malatesta, P., and Sefcik, S. 2001. Earnings management: IPO valuation and subsequent performance. Journal of Accounting, Auditing and Finance, 16(4): 369-397.

Durtschi, C., and Easton, P. 2004. Earnings Management? Alternative explanations for observed discontinuities in the frequency. SSRN working paper. 
Dyck, A. I. J., and Zingales, L. 2002. The corporate governance role of the media. CRSP working paper, 543, SSRN.com/abstract $=335602$.

Dyck, A., and Zingales, L. 2004. Private Benefits of Control: An International Comparison. Journal of Finance, 59(2): 537-600.

Ebrahim, A. 2007. Earnings management and board activity: an additional evidence. Review of Accounting \& Finance 6(1): 42-58.

Easton, P., and Harris, T. 1991. Earnings as an explanatory variable for returns. Journal of Accounting Research, 19-36.

Easton, P., and Zmijewski, M. 1989. Cross-sectional variation in the stock market response to accounting earnings announcements, Journal of Accounting and Economics, 11: 117-141.

Easterly, W., and Levine, R. 2002. Tropics, Germs, and Crops: How Endowments Influence Economic Development. NBER working Papers 9106, National Bureau of Economic Research. Retrieved at: http://www.ideas.repec.org/e/pea1.htm.

Eccles, R. G., Herz, R.H., Keegan, E.M., Phillips, D.M.H. 2001. The Value Reporting Revolution: Moving beyond the Earnings Game. Jhon Wiley, New York.

Elias, R. Z. 2004. The impact of corporate ethical values on perception of earnings management, Managerial Auditing Journal, 19(1): 84-98.

Erickson, M., and Wang, S. 1999. Earnings management by acquiring firms in stock for stock Mergers. Journal of Accounting and Economics, 27: 149-176.

Erickson, M., Hanlon, M., and Maydew, E. L. 2006. Is there a link between executive compensation and accounting fraud? Journal of Accounting Research, 44(1): 113-144.

Ewert, R., and Wagenhofer, A. 2005. Economic effects of tightening accounting standards to restrict earnings management. The Accounting Review, 80: 430-465.

Fama, E.F. 1980. Agency Problems and the Theory of the Firm. The Journal of Political Economy, 88(2): 288-307.

Fama, E.F. and M. Jensen. 1983. Separation of Ownership and Control. Journal of Law and Economics, 25: 301-325.

Fan, J. P., and Wong T. J. 2005. Do external auditors perform a corporate governance Role in emerging markets? Evidence from East Asia. Journal of Accounting Research, 43 (1): 35-71.

Farooque, O. A., van Zijl, T., Dunstan, K., and Karim, W. 2007. Ownership Structure and Corporate Performance: Evidence from Bangladesh. Asia-Pacific Journal of Accounting and Economics, 14(2):127-150. 
Farber, D. B., 2005. Restoring trust after fraud: Does corporate governance matter? The Accounting Review, 80(2): 539-561.

Financial Accounting Standards Board (FASB). 1985. Elements of financial statements. Statement of Financial Accounting Concepts No. 6. Norwalk, CT: FASB.

Financial Times (June 19, 2004). Retrieved at http://www.ft.com/home/USA.

FEE. 2001. Enforcement Mechanism in Europe: A preliminary investigation of oversight systems. Retrieved at www.fee.be/20Europe153200520952.pdf.

Firth, M., Fung, P., and Rui, O. 2002. Simultaneous Relationships among Ownership, Corporate Governance, and Financial Performance. Retrieved at http://ssrn.com/abstract=235225.

Fisman. R, and Gatti, R. 1999. Decentralization and corruption: Cross-country and cross state evidence. Unpublished Manuscript, World Bank, Washington D.C.

Foreign, B. 1999. The Economist, July 24: 54.

Frankel, R., McNichols, M., and Nelson, K. 2002. The relation between auditors' fees for non-audit services and earnings management. The Accounting Review, 77(Supplement): 71-105.

Francis, J., Philbrick, D., and Schipper, K. 1994. Shareholder Litigation and Corporate Disclosure. Journal of Accounting Research, 32 (2): 137-164.

Francis, J., Maydew, E., Sparks, H. 1999. The role of Big Six auditors in the credible reporting of accruals. Auditing: A Journal of Practice and Theory, 18 (2): $17-34$.

Francis, J. and Wang. D. 2008. The Joint Effect of Investor Protection and Big 4 Audits on Earnings Quality around the World. Contemporary Accounting Research, 25 (1):1-39.

Fong, A. 2006. Earnings management in corporate accounting: An overview. Cross-section, 2: 81-95.

Frost, C.A. 1999. Characteristics and information value of corporate disclosure of forward looking information in global equity markets. Working paper, Dartmouth College, USA.

Fudenberg, K., and J. Tirole. 1995. A theory of income and dividend smoothing based on incumbency rents. Journal of Political Economy, 103: 75-93.

Gilson, R. J., and Roe, M. J. 1993. Understanding the Japanese Kerietsu: Overlaps between corporate governance and industrial organization. Yale Law Journal, 102(4): 871-906. 
Gaver, J., Gaver, K., and Austin, J. 1995. Additional evidence on bonus plans and income management. Journal of Accounting and Economics, 19: 3-28.

Gray, S. 1988. Towards a theory of culture influence on the development of accounting systems internationally. Abacus, 24(1): 1-15.

Graff, M. 2006. Myths and Truths: The "Law and Finance" Theory Revisited. Review of Economics, 57(1): 51-76.

Goel, R.K., and Nelson, M.A. 1998. Corruption and Government Size: A Disaggregated Analysis. Public Choice, 11(2): 107-20.

Gompers, P., Ishii, J., and Metrick, A. 2003. Corporate governance and equity prices. Quarterly Journal of Economics, 118: 107-155.

Goodstein, J., Gautam, K., and Boeker, W. 1994. The effect of board size and diversity on strategic change. Strategic Management Journal, 15: 241-50.

Grossman, S., and Hart, O. 1980. Takeover Bids, the free-rider Problem, and the Theory of the Corporation. Bell Journal of Economics, 11: 42-64.

Grossman, S., and Hart, O. 1982. Corporate financial structure and managerial incentives, in The Economics of Information and Uncertainty (edited by J. J. MaCall) Chicago: The University of Chicago: 107-137.

Greenwald, B. B., and Stiglitz, J.E. 1990. Asymmetric Information and the new theory of the firm: Financial Constraints and risk behaviour. American Economic Review, 80(2):160-165.

Guay, W., Kothari, S., and Watts, R.1996. A Market-Based Evaluation of Discretionary Accrual Models. Journal of Accounting Research, 34(Supplement): 83-105.

Gul, F., and Tsui, J. 2001. Free Cash Flow, Debt Monitoring and Audit Pricing: Further Evidence on the Role of Director Equity Ownership", Auditing: A Journal of Practice \&Theory, 20(2): 71-84.

Guan, L., Pourjalali, H., Sengupta, P., and Teruya, J. 2005. Effect of cultural environment on earnings manipulation: A five Asia-Pacific country analysis. The Multinational Business Review, 13 (2): 23-41.

Guiso, L., Sapienza, P., Zingales, L. 2006. Does culture affect economic outcomes? Working paper, University of Rome, Northwestern University, and Harvard University.

Habib, A. 2005. Firms specific determinants of income smoothing in Bangladesh: An empirical evaluation. Advances in International Accounting, 18: 53-71. 
Habib, A. 2008. The role of accruals and cash flows in explaining security returns: Evidence from New Zealand. Journal of International Accounting, Auditing and Taxation, 17: 51-66.

Habib, A. and Islam, A. 2007. Determinants and consequences of non-audit service fees Preliminary evidence from Bangladesh. Managerial Auditing Journal, 22 (5): 446-469.

Hall, T., and Yago. G. 2000. Estimating the cost of opacity using sovereign bond spreads. Policy Brief, 13, Milken Institute, California.

Hall, R. E., and Jones, C. I. 1999. Why Do Some Countries Produce So Much More Output Per Worker Than Others? Quarterly Journal of Economics, 114(1):83-116.

Hall, B., and Liebman, J. 1998. Are CEOs really paid like bureaucrats? Quarterly Journal of Economics, 113: 653- 691.

Hall, B. J. 1999. The design of multi-year stock potions plans. Journal of Applied Corporate Finance, 12(2): 97-102.

Hall, S., and Stammerjohan, W. 1997. Damages Awards and Earnings Management in the Oil Industry. The Accounting Review, 72: 47-65.

Han, J., and Wang, S. 1998. Political costs and earnings management of oil companies during the 1990 Persian Gulf crisis. The Accounting Review, 73, 1998:103-117.

Hagerman, R., and Zmijewski, M. 1979. Some economic determinants of accounting policy choice. Journal of Accounting and Economics, August: 141161

Han, J.C.Y., and Wong, S. 1998. Political costs and earnings management of oil companies during the 1990 Persian Gulf crises. The Accounting Review, 73: 103117

Hanlon, M., RajGopal, S., Shevlin, T. 2003. Are executive stock options associated with future earnings? Journal of Accounting and Economics, 36(1-3): 3-43.

Hart, O. 1983. The Market Mechanism as an incentive scheme. Bell Journal of Economics, 14(2): 366-382.

Hart, O.1995. Corporate Governance: Some theory and implications. The Economic Journal, 105(May): 678-689.

Hayn, C. 1995. The information content of losses, Journal of Accounting and Economics, 20:125-153. 
Healy, P.M., and Wahlen, J. M. 1999. A review of the earnings management literature and its implications for standard setting. Accounting Horizons, 13(4): 365-383.

Healy, P., and Palepu, K.1993.The Effect of Firms' Financial Disclosure Policies on the Stock Prices. Accounting Horizons, 2:1-11.

Healy, P. 1985. The effect of bonus schemes on accounting decisions. Journal of accounting and Economics, 7: 85-107.

Harris, M., and Raviv, A. 1993. The theory of capital structure, Journal of Finance, 46: 297-356.

Haque, F. C. Kirkpatrick and T. Arun. 2006. Political Economy of Corporate Governance in Bangladesh. Centre on regulation and Competition, Institute for Development Policy and Management. Working Paper No. 127, University of Manchester, UK.

Hribar, P., Jenkins, N. T., and Johnson, B. 2006. Stock repurchases an earnings management device. Journal of Accounting and Economics, 41(1-2): 3-27.

Holthausen, R.W., and Larcker, D. 1996. The financial performance of reverse leveraged buyouts. Journal of Financial Economics, 42 (3): 293-332.

Holthausen, R., Larcker, D., and Sloan, R. 1995. Annual Bonus Schemes and the Manipulation of Earnings. Journal of Accounting \& Economics, 19: 29-74.

Hofstede, G.H. 1980. Culture's Consequences: International Differences in Work Related Values. Sage Publications, Beverly Hills, CA.

Hofstede, G. H. (2001), Culture's Consequences: Comparing Values, Behaviours, Institutions, and Organizations across Nations, Sage Publications, Thousand Oaks, CA.

Holland, 2004. Earnings Management: A Methodological Review of the Distribution of Reported Earnings Approach. Retrieved at http://ssrn.com/abstract $=432531$.

Holland, K. E., and Jackson, R. G. H. 2004. Earnings management and deferred tax. Accounting and Business Research, 34 (2):101-123.

Holmstrom, B. R. 1979. Moral Hazard and observability. The Bell Journal of Economics, 10(1): 74-91.

Holthausen, R.W. 2003. Testing the relative power of accounting standards versus incentives and other institutional features to influence the outcome of financial reporting in an international setting. Journal of Accounting and Economics, 36: 235-272. 
Holthausen, R., Larcker, D. and Sloan, R. 1995. Annual bonus schemes and the manipulation of earnings. Journal of accounting and Economics, 19: 29-74.

Hope, O-K. 2003 . Disclosure practices, enforcement of accounting standards, and analysts forecasts accuracy: an international study. Journal of Accounting Research, 41: 235-272.

Hope, O-K. 2003b. Firm-level disclosures and the relative roles of cultures and legal origin. Journal of International Financial Management and Accounting, 14(3): 218-248.

Hope, O -K., Kang, T., Thomas, W., Yoo, Y. K. 2008. Culture and auditor choice: A test of the secrecy hypothesis, Journal of Accounting \& Public Policy, 27: 357373.

House, R. J., Hanges, P. J., Javidan, M., Dorfman, P. W., Gupta, V. 2004. Culture, Leadership and Organizations: The Global Study of 62 Societies. Sage Publications, Inc

Houqe, M. N., vanZijl, T., Dunstan, K., and Karim, W. 2008. A Review of Contemporary Earnings Management. Working Paper (APC Conference presentation, Paris 2008), Victoria University of Wellington.

Houqe, M. N., vanZijl, T., Dunstan, K., and Karim, W. 2008. Does Corporate Governance affect Earnings Quality: Preliminary Evidence from Bangladesh? Working paper (APC Conference presentation, Las Vegas 2009), Victoria University of Wellington.

Hoopes, J., Malagueno, R., Albrecht, C., and Albrecht, W.S. 2006. Accounting and Corruption: A Cross-Country Analysis. Retrieved at http://ssrn.com/abstract $=536672$.

Hsu, G., and Koh, P. S. 2005. Does the presence of Institutional investors influence accruals accounting? Evidence from Australia. Corporate Governance, 13 (6): 809-823.

Hu, A. (2000). China: Corruption and Anti-Corruption strategies. Working paper, Tsinhua University, Beijing.

Hughes, J.W., and Snyder, E.A. 1995. Litigations and settlement under the English and American Rules: Theory and Evidence. Journal of Law and Economics, 38(1): 225-250.

Hung, M. 2001. Accounting standards and value relevance of financial statement: an international analysis. Journal of Accounting \& Economics, 30(3): 401-420.

Husted, B. 1999. Wealth, Culture, and Corruption. Journal of International Business Studies, 30(2): 339-359. 
Hayn, C.1995. The information content of losses. Journal of Accounting and Economics, 20: 125-153.

IMF.1997. 1997 Annual Meetings. Boards of Governors World Bank Group International Monetary Fund, Hong Kong, China.

Islam, M.S., Uddin, M. M., and Ahmed, S. 2002. The operating performance of firms conducting seasoned equity offerings in Bangladesh. Dhaka University Journal of Business Studies, 23(2): 205-217.

Iqbal, M. 1997. Recent Developments in Corporate Governance and their Impact on Management Practices. Public Finance and Developments, 1 (2): 215-234.

Jacobson, R., and Aaker, D.1993. Myopic management behaviour with efficient, but imperfect financial markets: A comparison of information asymmetries in the U.S. and Japan. Journal of Accounting \& Economics, 16(4): 383-405.

Jaggi, B., Low, P.Y. 2000. Impact of culture, market forces, and legal systems on financial disclosures. International Journal of Accounting 35 (4), 495-519.

Jain, A. (2001). Corruption: A Review. Journal of Economic Surveys, 15(1): 1535.

Jenkins, N. 2002. Auditor independence, audit committee effectiveness, and earnings management. Working paper, Washington University, USA.

Jensen, M. 1988. Takeovers: Their causes and consequences. Journal of Economic Perspectives, 2(1): 21-48.

Jensen, M.1986. Agency costs of free cash flow, corporate finance, and takeovers. American Economic Review, 76: 323-329.

Jensen, M.C. 1993. The modern industrial revolution, exit and the failure of internal control systems. The Journal of Finance, 48: 831-80.

Jensen, M. C., and W. H. Meckling. 1976. Theory of firm: Managerial behaviour, agency costs and ownership structure. Journal of Financial Economics, 3: 305360 .

Jeter, D.C., and Shivakumar, L. 1999. Cross-sectional estimation of abnormal accruals using quarterly and annual data. Effectiveness in detecting event-specific earnings management. Accounting and Business Research, 29(4): 299-319.

Johnson, M., Kasznik, R., and Nelson, K. 2000. Shareholder Wealth effects of the Private Securities Litigation Reform Act of 1995. Review of Financial Studies, 5(3): 217-233.

Jiraporn, P., and Daldalt, P. J. 2007. Does founding family control affect earnings management? An empirical note. Retrieved at http://ssrn.com/abstract $=632621$. 
Johl, S., Jubb, C. A., Houghton, K. A. 2007. Earnings management and the audit opinion: Evidence from Malaysia. Managerial Auditing Journal, 22(7): 688-715.

Jones, J.J. 1991. Earnings management during import relief investigation. Journal of Accounting Research, 29(2): 193-228.

Jones, S., and Sharma, R. 2001. The impact of free cash flow, financial leverage and accounting regulation on earnings management in Australian 'Old' and 'New' economics. Managerial Finance, 27: 18-38.

Judge, G., Hill, R. Griffiths, W., Lutkepohl, H., Lee, T.1988. Introduction to the theory and practice of econometrics. 2nd ed. New York.

Kahneman, D., and Tversky A. 1979. Prospect theory: an analysis of decisions under risk. Econometrica, 47: 263-291.

Kalay, A. 1982. Stockholder-bondholder conflict and dividend constraints. Journal of Financial Economics: 211-233.

Karim, A. K. M. W. 1995. Provision of Corporate Financial Information in Bangladesh, PhD dissertation, School of Business and Economic Studies, University of Leeds, UK.

Karim, A. K. M. W., and van Zijl, T. 2008. Role of corporate governance in influencing auditor choice in emerging audit services market. Working paper, Victoria University of Wellington.

Kabir, M H., Islam, A., Sharma, D., and Salat, A. 2008. Association between Auditor quality and earnings quality - Do local big four auditors provide qualitydifferentiated audits in Bangladesh, Conference paper, Asia-pacific conference on international accounting issues November 9-12, Paris France.

Kantor, M. 1996. Remarks at Detroit Economic Club. Available at http://www.usembassy-isreal.org.il/publish/press/commerce/archieve/july/dc1_7 30.htm.accessed 11/23/2009.

Kang, S-H. 2005. A conceptual and empirical evaluation of accrual prediction models. $\underline{\text { http: } / / \text { ssrn.com/abstract }=147259}$.

Kaplan, S. N. 1994. Top executives, turnover, and firm performance in Germany. Journal of Law Economics, and Organization, 10(1):142-159.

Kaplan, S. N., and Minton, B. A. 1994. Appointments of outsiders to Japanese boards-determinants and implications for managers. Journal of Financial Economics, 36(2): 225-258.

Kasznik, R. 1999. On the association between voluntary disclosures and earnings management. Journal of Accounting Research, 37(1): 57-82. 
Kasznik, R., and M. McNichols. 2002. Does Meeting Expectations Matter? Evidence from Analyst Forecast Revisions and Share Prices. Journal of Accounting Research, 40: 727-759.

Kedia, S., and Philippon, T. 2005. The Economics of Fraudulent Accounting. AFA 2006 Boston Meeting Paper. Retrieved at http://ssrn.com/abstract $=328661$.

Kelly, S. 2004.The Market Premium for the Option to Close: Evidence from Australian Gold Mining Firms. Retrieved at http://ssrn.com/abstract $=348781$.

Kellogg, R. L. 1984. Accounting activities, securities prices, and class action lawsuits. Journal of Accounting \& Economics, 6(3):185-204.

Keasey, K., Wright, M. 1997. Corporate Governance: Responsibilities, Risks and Remuneration. Hohn Wiley \& Sons.

Kerstein, J., and Rai, A. 2007. Intra-Year Shifts in the Earnings Distribution and their Implications for Earnings Management. Journal of Accounting and Economics, 44: 399-419.

Klein, A. 2002a. Economic Determinants of Audit Committee Independence. Accounting Review, 77(2): 435-453.

Klein, A. 2002b. Audit committee, board of director characteristics, and earnings management. Journal of Accounting and Economics, 33(3): 375-400.

Key, K.G. 1997. Political cost incentives for earnings management in the cable television industry. Journal of Accounting and Economics, 23 (3): 309-337.

Kinnunen, J., Kasnaen, E., and Niskanen, J.1995. Earnings management and the economic sector hypothesis: empirical evidence on a converse relation in the finish case. Journal of Business, Finance and Accounting, 22: 497-520.

Knack, S., and Keefer, P. 1995. Institutions and Economic Performance: CrossCountry Tests Using Alternative Institutional Measures. Economics and Politics, 7(3): 207-227.

Koch, T.W., and Wall, L. D. 2000. The use of accruals to manage reported earnings: theory and evidence. Working Paper, Federal Reserve Bank of Atlanta, USA.

Krishnan, G. 2003a. Audit quality and the pricing of discretionary accruals. Auditing: A Journal of Practice and Theory, 22: 109-126.

Krishnan, G. 2003b. Does big 6 auditor industry expertise constrain earnings management? Accounting Horizons, 17: 1-16.

Kole, S. R, and Mulherin, J.H. 1997. The Government as a shareholder: A case from the United States. Journal of Law and Economics, 40: 1-22. 
Kormendi, R., and Lipe, R. 1987. Earnings innovation, earnings persistence and stock returns. Journal of Business, 60: 323-345.

Kothari, S., Leone, A., and Wasley, C. 2005. Performance Matched Discretionary Accrual Measures. Journal of Accounting and Economics, 39(1):163-197.

Kothari, S.P. 2001.Capital Market Research in Accounting. Journal of Accounting and Economics, 31(1-3):105-231.

Kothari, S.P. 2000. The role of financial reporting in reducing financial risks in the market. Available at: http://bosfed.org/home

Kaufmann, D., and Wei, S. 2000. Does 'grease money' speed up the wheels of commerce? Working Paper. WP/00/64. Washington DC: International Monetary Fund.

Kufamnn, D., Kraay, A., and Zoido- Lobatón, P .1999. Governance Matters. Policy Research Working Paper. The World Bank, Development Research Group.

La Porta, R., Lopez-de-Silanes, F., Shleifer, A., and Vishny, R. W. 1997a. Legal Determinants of External Finance" Journal of Finance, 52(3):1131-1150.

La Porta, R., Lakonishok, J., Shleifer, A., and Vishny, R.W. 1997.Good news for value stocks: Further evidence on market efficiency. Journal of Finance, 52(2):859-874.

La Porta, R., Lopez-de-Silanes, F., and Shleifer, A. 1998. Law and Finance. Journal of Political Economy, 106 (6): 1113-1154.

La Porta, R., Lopez-de-Silanes, F., Shleifer, A. 1999. Corporate Ownership around the world. Journal of Finance, 54(2):471-571.

La Porta, R., Lopez-de-Silanes, F., Shleifer, A., and Vishny, R.W. 2000. Investor protection and corporate governance. Journal of Financial Economics, 58(October-November): 3-27.

La Porta, R., F. Lopez-de-Silanes, and A. Shleifer. 2006. What works in securities laws? Journal of Finance, 61(February): 1-32.

Larcker, D. 2003. Discussion of: Are executive stock option associated with future earnings. Journal of Financial Economics, 36: 91-103.

Larker, D., and Richardson, S. 2004. Fees paid to audit firms, accrual choices and corporate governance. Journal of Accounting Research, 42: 625-658.

Larcker, D.F., Richardson, S.A., and Tuna, I. 2007. Corporate Governance, Accounting Outcomes, and Organizational Performance. The Accounting Review, 82(4): 963-1008. 
Lawrence, J., Stapledon, G.1999. Is Board Composition Important? A Study of Listed Australian Companies. Working paper, University of Melbourne.

Lee, K.W., Lev, B., and Yeo, G. 2007. Organizational structure and earnings management. Journal of Accounting, Auditing and Finance, 22(2): 293-331.

Leiken, R. 1997. Controlling the Global Corruption Epidemic. Foreign Policy, 105: 55-73.

Lennox, C.S.2005. Audit Quality and executive officers' affiliations with CPA firms. Journal of Accounting and Economics, 39(2): 201-231.

Leuz, C., Nanda, D., and Wysocki, P.D. 2003. Investor protection and earnings management: An international comparison. Journal of Financial Economics, 69: 506-527.

Levit, A. 1998. Remarks by Chairperson of the SEC. The Number Game. New York University Centre for Law and Business (September).

Lev, B.1989. On the Usefulness of Earnings and Earnings Research: Lessons and Directions from Two Decades of Empirical Research. Journal of Accounting Research, 27(3):153-193.

Lev, B. 2000. New Accounting for New Economy. ASX Monthly Roundup, Australia (See Huntley's2001).

Lev, B., and Aboody, D. 2000. Information Asymmetry, R\&D, and Insider Gains. The Journal of Finance, 55(6): 2747-2766.

Lichtenberg, F.R., and Pushner, G.M. 1994. Ownership structure and corporate performance in Japan. Japan and the World Economy, 6(3): 239-261.

Lipton, M., Lorsch, J.W. 1992. A Modest Proposal for Improved Corporate Governance. Business Lawyer, 48(1): 59-78.

Liu, Q., and Lu, Z. 2002. Earnings management to tunnel: Evidence from China's listed companies. Working paper, McKinsey \& Company and University of Hong Kong.

Lin, J. W., Li, J. F. and Yang, J. S. 2006. The effect of audit committee performance on earnings quality. Managerial Auditing Journal, 21(9): 921-933.

Lin. H., and Paananen, M. 2007. The Development of Accounting Quality of IAS and IFRS over Time: The Case of Germany. http://ssrn. com/abstract=632681.

Lopez, T. J., and Ress, L. L. 2001. The effect of meeting analysts' forecasts and systematic positive forecast errors on the information content of unexpected earnings. http://ssrn.com/abstract $=138681$. 
Loughran, T., and Ritter, J. R. 1995. The new issues puzzle. Journal of Finance 50: 23-51.

Loughran, T., and Ritter, J. 1997. The operating performance of firms conducting seasoned equity offerings. Journal of Finance, 52: 1823-1850.

Lys, T., and Watts, R. 1994. Lawsuits against auditors. Journal of Accounting Research, 32(supplement): 65-93.

Malinvaud, E. 1980. Statistical Methods of Econometrics. North-Holland Publishing Company, Amsterdam.

Maher, M., Andersson, T. 2000. Corporate Governance: Effects on Firm Performance and Economic Growth. OECD working paper.

Manne, H. G. 1965. Insider Trading and the Stock Market. New York, Free Press.

Martin, K. J., and McConnell, J. J. 1991 Corporate performance, corporate takeovers and management turnover. Journal of Finance, 46: 671 - 688.

Mauro, P.1995. Corruption and Growth. Quarterly Journal of Economics, 110(August): 681-712.

Mauro, P. 1997. The effects of corruption on growth, investment and government expenditure: A cross-country analysis. Corruption in the global economy, Edited by Kimberly Ann Elliott (Washington: Institute for International Economics).

McChesney, F. 2001. Rent Seeking and Rent Extraction in The Elgar Companion to Public Choice. Edward Elgar.

McNichols, M. F. 2000. Research design issues in earnings management studies. Journal of Accounting and Public Policy, 19: 313-345.

McNichols, M. F., and Stubben, S. R. 2005. Does earnings management effect firms investment decisions? Working paper, Stanford University, USA.

McNichols, M.F., and G.P. Wilson. 1988. Evidence of earnings management from the provision for bad debts. Journal of Accounting Research, 26 (supplement): 131 .

Macrae, J. 1982. Underdevelopment and the economics of corruption: A game theory approach. World Development, 10(8): 677-687.

McConnell, J., Servaes, H. 1990. Additional evidence on equity ownership and corporate Value. Journal of Financial Economics, 27: 595-613.

Meck, G. K., Rao, R. P., and Skousen, C. J. 2007. Evidence on factors affecting the relationship between CEO stock option compensation and Earnings management. Review of Accounting \& Finance, 6(3): 304-323. 
McVay, S. 2006. Earnings management using classification shifting: An examination of core earnings and special items. The Accounting Review, 81(3): 501-530.

Mikhail, M. B., Walther, B. R., and Willis, R. H. 2004. Earning surprises and the cost of equity capital. http://ssrn.com/abstract=504662.

Morck, R., Yeung, B., Yu, W. 2000. The information content of stock markets: Why do emerging markets have synchronous price movements? Journal of Financial Economics, 58(1-2): 215-260.

Morck, R., Shleifer, A., and Vishny, R.W.1988. Management ownership and market valuation: An empirical analysis. Journal of Financial Economics, 20: 293-315.

Moyer, S. 1990. Capital adequacy ratio regulations and accounting choices in commercial Banks. Journal of Accounting and Economics, 12: 123-154.

Mueller, G. G. (1968). Accounting Principles Generally Accepted in the United States Versus Those Generally Accepted Elsewhere. International Journal of Accounting Education and Research, (spring): 91-103.

Mulford, C.W., and Comiskey, E.E. 2002. The financial number game: Detecting creative accounting practices. Jhon Wiley \& Sons Inc.

Myers, L., and Skinner, D. 1999. Earnings momentum and earnings management. Working paper, University of Michigan.

Nabar, S., and K. K. Boonlert-U-Tahi. 2007. Earnings Management, Investor Protection, and Natural Culture. Journal of International Accounting Research, 6(2): 35-54.

Nenova T. 2000. The Value of Corporate Votes and Control Benefits: A Cross Country Analysis. Retrieved at http://ssrn.com/abstract=237809

Nobes C. W. 1988. The Causes of Financial Reporting Differences. An Issues in Multinational Accounting, edited by C. W. Nobes and R. H. Parker, Oxford, Philip Allan.

Nobes C. W. 1992. International Classification of Financial Reporting, Second Edition, Routledge, London and New York.

North, D. C., and Weingast, B. 1989. Constitution and Commitment: The Evolution of Institutional Governing Public Choice in Seventeenth-Century England. The Journal of Economic History, 49(4): 803-832.

Organisation for Economic Co-operation and Development (OECD). 1995. Financial Markets and Corporate Governance. Financial Market Trends, 62 (Nov).

Organisation for Economic Co-operation and Development (OECD). 1999. OECD Principles of Corporate Governance. 
Offerman, L. R., and Hellman, P. S. 1997. Culture's consequences for leadership behavior: National values in Action. Journal of Cross-Cultural Psychology, 28: 342-351.

Paananen. M. 2008. The IFRS Adoption's Effect on Accounting Quality in Sweden. Working paper, University of Hertfordshire, UK.

Paek, W., and Press, E. 1997. Discretionary accruals, managers`incentives and stock prices. Working paper, Sung Kyun Kwan University.

Palmorse, Z. 1987. Litigation and independent auditor: The role of business failures and management fraud. Auditing: A Journal of Practice \& Theory, 6 (spring): 90-103.

Palmrose, Z.1988. An analysis of auditor litigation and audit service quality. Accounting Review, 63: 55-73.

Park, M. S., and Park, T. 2004. Insider Sales and Earnings Management. Journal of Accounting \& Public Policy, 23(5): 381-411.

Payne, J., Robb, S. 2000. Earnings Management: The Effect of Ex Ante Earnings Expectations. Journal of Accounting, Auditing and Finance, 15(4): 371-392.

PCAOB (The Public Company Accounting Oversight Board). 2009. Retrieved at www.pcaobus.org/home

Peasnell, P., Pope, P., Young, S. 1998. Outside Directors, Board Effectiveness, and Earnings Management. Working paper, Lancaster University.

Peasnell, P., Pope, P., Young, S.2000. Detecting earnings management using cross-sectional abnormal accruals models. Accounting and Business Research, 30: 313-326.

Peasnell, P.2006. Do outside directors limit earnings management: Corporate Finance Review, 10(5): 5-10.

Peasnell, P., Pope. P, Young. S.2005. Board monitoring and earnings management: Do outside director's influence abnormal accruals? Journal of Business Finance and Accounting, 32(7-8): 1311-1346.

Pedhazur, E.1997. Multiple regressions in behavioural research: explanation and prediction. 3rd ed., Forth Worth: Harcourt Brace College Publishers.

Pelapu, K. 1986. Predicting takeover targets: A methodological and empirical analysis. Journal of Accounting and Economics, 8(1): 3-35.

Peng, L., and Roell, A.A. 2006. Executive pay, earnings manipulation and shareholder litigation. AFA 2005 Meeting Paper. SSRN.com/Abstract $=488148$.

Pergola, T. 2006. Management Entrenchment, Corporate Governance and Earnings Quality. Working paper, Nova Southern University. 
Perry, S., Williams, T.1994. Earnings management preceding management buyout offers. Journal of Accounting and Economics, 18: 157-180.

Petroni, K.1992. Optimistic reporting in the property-casualty insurance industry. Journal of Accounting and Economics, 15: 485-508.

Petrovits, C. 2006. Corporate-Sponsored Foundations and Earnings Management. Journal of Accounting and Economics, 41(3): 335-362.

Peter, D. W. 2004. Earnings Management, Tax Compliance, and Institutional Factors: A Discussion of Haw et al. (2004). Working paper, Sloan School of Management, Massachusetts Institute of Technology.

Pierre, M.G., and Sekkat, K. 2005. Does corruption grease or sand the wheels of growth? Public Choice, 122(1-2).

Platikanova, P., and Nobes, C. 2006. Was the Introduction of IFRS in Europe Value- Relevant? Working Paper, University Pompeu Fabra and University of Reading.

Pourjalali, H., Meek, G. 1995. Accounting and culture: the case of Iran. Research in Accounting in Emerging Economies, 3: 3-17.

Rahman, R. A., and Ali, F. H. M. 2006. Board, Audit Committee and Earnings Management: Malaysian Evidence. Managerial Auditing Journal, 21(7): 783-804.

Rajgopal, S., and Shivakumar, L. 2007. A Catering Theory of Earnings Management. Working paper, University of Washington Business School and London Business School.

Rath. S., and Sun, L. 2007. Do Australian Firms Engage in Earnings Management? Working Paper, Curtin University of Technology, Australia.

Rangan, S. 1998. Earnings management and the performance of seasoned equity offerings. Journal of Financial Economics, 50: 101-122.

Richardson, S.A., Tuna, I. A., and Wu, M. 2002. Predicting earnings management: The case of restatements. Retrieved at http://ssrn.com/abstract $=338681$

Robinson, T., Grant, J.1997. The impact of earnings management on bond risk premia. Advances in Accounting, 15:169-192.

Rock, M. T., and Bonnett, H. 2004. The Comparative Politics of Corruption: Accounting for the East Asian Paradox in Empirical Studies of Corruption, Growth and Investment. World Development, 32(6):999-1017.

Roe, M. 1994. Strong Managers, Weak Owners: The Political Roots of American Corporate Finance. Princeton University Press, Princeton, N.J. 
Rogers, W. H. 1993. sg17: Regression Standard Errors in Clustered Samples. Stata Technical Bulletin, 13:19-23.

Romano, R. 1993. The genius of American Corporate Law. American Enterprise Institute Press, Washington, D.C.

Rose-Ackerman, S. 1978. Corruption: A study in Political Economy. New York: Academy Press.

Rose-Ackerman, S. 2002. "Grand" Corruption and the Ethics of Global Business. Journal of Banking and Finance, 26:1889-1919.

Rubin, P. 1990. Managing business transactions: Controlling the cost of coordinating, communicating, and decision making. Maxwell Macmillan International.

Salter, S., and Niswander, F. 1995. Culture influence on the development of accounting systems internationally: A test of Gray's (1988) theory. Journal of International Business Studies, 29(1): 159-177.

Sarbanes-Oxley Act 2002, part of the SEC's Regulation SOX, Federal law.

Schipper, K. 1989. Commentary on earnings management. Accounting Horizons, 3(4): $91-102$.

Schipper, K. 2005. The introduction of International Accounting Standards in Europe: implications for international convergence. European Accounting Review, 14(1):101-26.

Scholes, M., Wilson, G.P., and Wolfson, M. 1990. Tax Planning, Regulatory capital planning, and financial reporting strategy for commercial banks. Review of Financial Studies, 3: 625-650.

Schuler, R., and Rogovsky, N. 1998. Understanding compensation practice variations across firms: The impact of national culture. Journal of International Business studies, 29(1): 159-177.

Seligson, M. 2002. The Impact of Corruption on Regime Legitimacy: A Comparative Study of Four Latin Countries. The Journal of Politics, 64(2): 408433.

Share and Share, U. 1999. The Economist. August 7:18-19.

Shen, C., and Chih, H. 2005. Investor protection, prospect theory, and earnings management: An international comparison of the banking industry. Journal of Banking \& Finance, 29: 2675-2697.

Shivakumar, L.2000. Do Firms Mislead Investors by Overstating Earnings before Seasoned Equity Offerings? Journal of Accounting and Economics, 29(3): 339371. 
Shleifer, A., and Wolfenzon, D. 2000. Investor Protection and Equity Markets. Working Paper. Harvard University and New York University

Shleifer, A., and Vishny, R.W. 1993. Greenmail, white knights, and shareholders' interest. RAND Journal of Economics, 17(3): 293-310.

Shleifer, A., and Vishny, R.W. 1997. A survey of corporate governance. Journal of Finance, 52(2): 737-783.

Shleifer, A., and Vishny, R.W.1986. Large Shareholders and Corporate Control. Journal of Political Economy, 94: 461-488.

Shivakumar, L. 2002. Do Firms Mislead Investors by Overstating Earnings before Seasoned Equity Offerings? Journal of Accounting and Economics, 29(3): 339371.

Skinner, D. J., and Sloan, R.G. 2002. Earnings surprises, growth expectations and stock returns or don't let an earnings torpedo sink your portfolio. Review of Accounting Studies, 7(2-3): 289-312.

Spamann, H. 2006. On the significance and/or endogeneity of La Porta et al's 'Anti Directors Rights Index' under consistent coding. Discussion Paper No. 7. Harvard Law School.

Stice, E. 1991. The market reaction to $10-\mathrm{K}$ and 10-Q filing and to subsequent The Wall Street Journal earnings announcements. The Accounting Review, 66(January): 42-55.

Stulz, R. M., and Williamson, R. 2003. Culture Openness and Finance. Journal of Financial Economics, 70(3): 313-349.

Soderstrom, N. S., and Sun, K. J. 2008. IFRS Adoption and Accounting Quality: A Review. European Accounting Review, 16(4): 675-702.

Spiess, D. K. and Affleck-Graves, J. 1995. The Long -run performance of stock returns following debt offerings. Journal of Financial Economics, 54: 45-74.

Subramanyam, K. R. 1996. The pricing of discretionary accruals. Journal of Accounting and Economics, 22: 249-281.

Sunder, S. 1997. Theory of Accounting and control. Cincinnati, OH: SouthWestern Publishing.

Stapleton, G.P. 1998. Australian Share market ownership. Securities Regulation in Australia and New Zealand. Sydney: LBC Information Service.

Sweeney, A. 1994. Debt-Covenant Violations and Managers' Accounting Responses. Journal of Accounting and Economics, 281-308. 
Tanzi, V., and Davoodi, H.1997. Corruption, Public Investment and Growth. IMF Working Paper 97/139. Retrieved at http://www1.worldbank.org/home

Tanzi, V. 1998. Corruption around the world: causes, consequences, scope, and cures. IMF Staff Papers, 45(5): 559-594.

Teoh, S.H., and Wong, T.J. 1993. Perceived Auditor Quality and the Earnings Response Coefficients. The Accounting Review, 68: 346-367.

Teoh, S.H., Welch, I., and Wong, T.J. 1998. Are Accruals during Initial Public Offerings Opportunistic? Review of Accounting Studies, 3:175-208.

Teoh, S.H., Welch, I., and Wong, T.J. 1998a. Earnings management and the longterm market performance of initial public offerings. Journal of Finance, 53 (December): 1935-1974.

Teoh, S., Welch, I., Wong, T.1998b. Earnings Management and the Underperformance of Seasoned Equity Offerings. Journal of Financial Economics, 50: 63-99.

Terisman, D.2000. The causes of corruption: a cross-national study. Journal of Public Economics, 76: 399-457.

The World Economic Forum. 2008. The Financial Development Report. USA. Retrieved at http://www.weforum.org/en/index.htm

The World Factbook. 2009. Central Intelligence Agency, USA. Retrieved at http://www.cia.com/home/usa

The World Bank. (1998-2007). The World Bank Development Research Group. Retrieved at http://www.worldbank.org

Thomas, J., and Zhang, X. 2000. Identifying unexpected accruals: A comparison of current approaches. Journal of Accounting and Public Policy, 19: 346-376.

Transparency International. 2008. Transparency International's Corruption Perception Index, 2008. Retrieved at http://www.transparency.org/home

Uddin, S.N. and Hopper, T.M. 2003. Accounting for privatization in Bangladesh: Testing World Bank Claims. Critical Perspective on Accounting, 14: 739-774.

van. T, B., and Vanstraelen, A. 2005. Earnings management under German GAAP versus IFRS. European Accounting Review, 14(1): 155-80.

United Nations. 2008. Annual Report. Retrieved at http://www.un.org/home

Viscusi, W. K., J. E. Harrington., and Vernon, J. M. 2005. Economics of Regulation and Antitrust. 4th Edition, MIT press. 
Vogl, F. 1998. The supply side of global Bribery. Finance and Development, 35(2): 30-33.

Warfield, T., and Wild, J. 1995. Managerial ownership, accounting choices, and informativeness of earnings. Journal of Accounting and Economics, 20: 61-91.

Wang, Z., Swift, K., Lobo, G.1994. Earnings management and the informativeness of accruals adjustments. Working paper, Motana State University.

Wang, T.Y.2004. Investment, shareholder monitoring, and economics of corporate securities fraud. Working Paper, University of Maryland.

Watts, R., and Zimmerman, J. 1978. Towards a Positive Accounting Theory of the determination of accounting standards. The Accounting Review, 53 (January): 112-134.

Watts, R., and Zimmerman, J. 1986. Positive Accounting Theory. Englewood Cliffs, Prentice-Hall, Inc.

Watts, R., and Zimmerman, J. 1990. Positive Accounting Theory: A ten Year Perspective. The Accounting Review, 65: 131-156.

WBES. 2000. (World Business Environment Survey), Annual Report. Retrieved at http://www.wbes.org/home

Weber, M. 2006. Sensitivity of executive wealth to stock price, corporate governance and earnings management. Review of Accounting \& Finance, 5(4): 321-354.

Wei, S. J. (1999), Corruption and Economic Development: Beneficial Grease, Minor Annoyance or Major Obstacle? The World Bank, Washington, DC, Policy Research Paper No. 2048, Public Economics, Development Research Group.

Wei, S. J. 2000. How taxing is corruption on International Investors. The Review of Economics and Statistics, 82(1): 1-11.

Weisbach, M. 1988. Outside directors and CEO turnover. Journal of Financial Economics, 20(1-2): 413-460.

White, H. 1980. A Heteroscedasticity-consistent Covariance Matrix Estimator and a Direct Test for Heteroscedasticity. Econometrica, 48: 817-838.

Wild, J. 1996. The audit committee and earnings quality. Journal of Accounting, Auditing and Finance, 11: 247-276.

Wilson, P. 1996. Discussion: write-offs: manipulation or impairment? Journal of Accounting Research, 34:171-177.

WHO. 2008. (World Health Organization). Annual Report. Retrieved at http://www.who.org/home 
Willamson, O. E. 1979. Transaction Cost Economics: The Governance of Transactional Relations. Journal of Law and Economics, 22: 233-261.

Wright, C. J., Shaw, J. R., and Guan, L. 2006. Corporate Governance and Investor Protection: Earnings Management in the UK and the US. Journal of International Accounting Research, 5 (1): 25-40.

Wu, X. 2005. Firm Accounting Practices, Accounting Reform and Corruption in Asia. Policy and Society, 24(3): 53-78.

Wu, X. 2005a. Corporate Governance and Corruption: A Cross- country Analysis. Governance: A International Journal of Policy, Administrative and Institutions, 18(2):151-170.

$\mathrm{Wu}, \mathrm{X}$. 2005b. Political Institutions and Corporate Governance Reform in Southeast Asia. In Reforming Corporate Governance in Southeast Asia: Economics, Politics and Regulation, ed. K. L. Ho, ISEAS, Singapore.

Xie, B., Davidson, N.W. and DaDalt, P. 2003. Earnings management and corporate governance: the roles of the board and the audit committee. Journal of Corporate Finance, 9 (3): 295-316.

Xu, X., and Wang, Y. 1999. Ownership structure and corporate governance in Chinese stock companies. China Economic Review, 10: 75-89.

Yaari, H., DaDalt, P., Ronen, J., and Yaari, V. 2007.An accruals conundrum in earnings management research. Work in Process. New York University and Morgan State University.

Ye, J. 2006. Accounting Accruals and tests of earnings management. Working paper, Baruch College, NY.

Yermack, D. 1996. Higher market valuation of a company with a small board of directors. Journal of Financial Economics, 40: 185-211.

Yoon, S.S., and Miller, G.A. 2002. Cash from operations and earnings management in Korea. The International Journal of accounting, 37: 395-412.

Young, M. 2000. Accounting Irregularities and Financial Fraud: Corporate Governance Guide, Harcourt, Inc.

Yu, M. 2005. International Earnings Management and Accounting Standards. SSRN working paper. Retrieved at http://ssrn.com/abstract $=825146$

Zahra, S., and Pearce, J. 1989. Boards of directors and corporate financial performance: A review and integrative model. Journal of Management, 15: 291334. 
Appendix - A

\section{Statistical Output}

Table 5-1

Panel A: Sample distribution by country and year

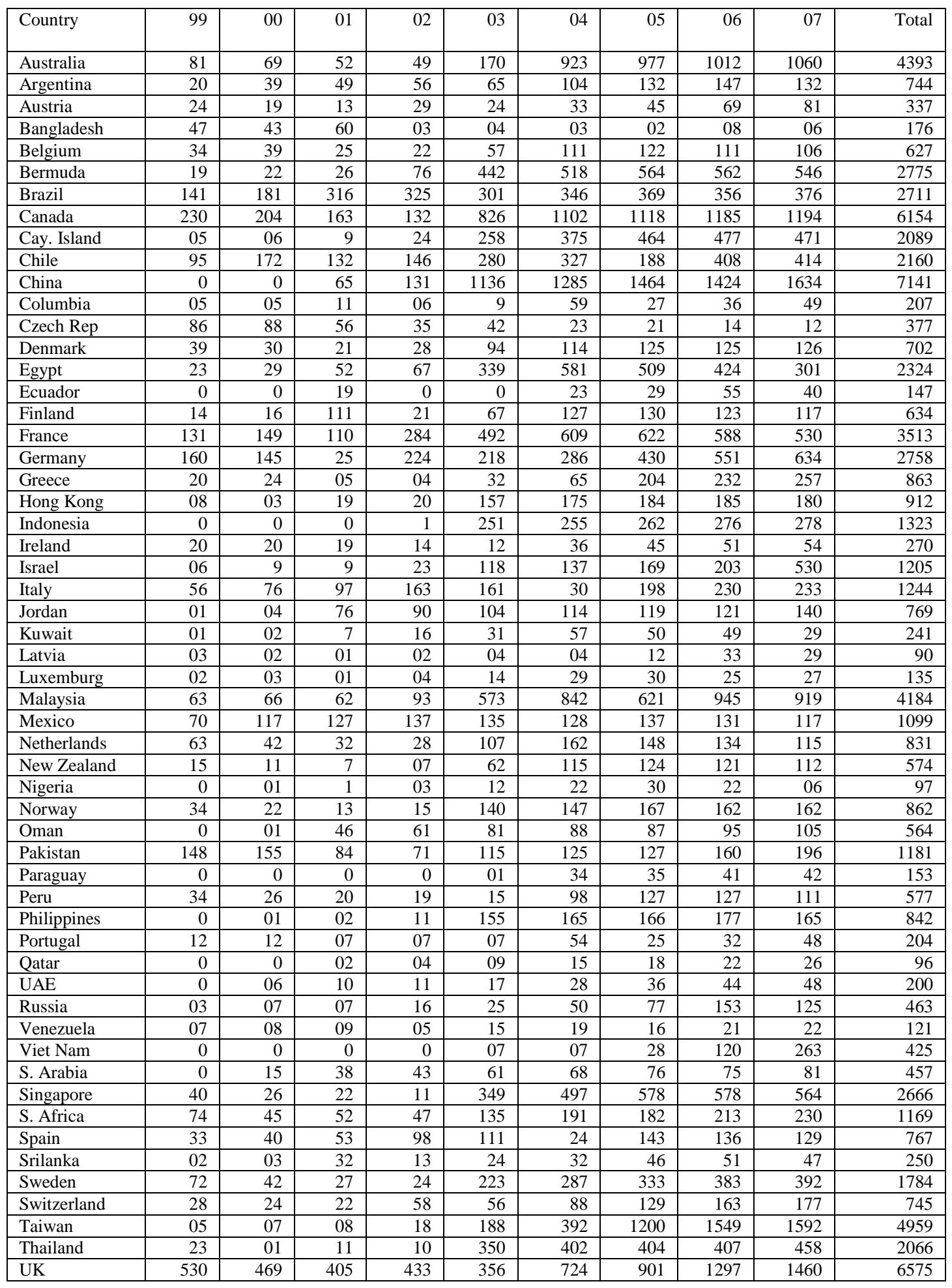




\begin{tabular}{|l|r|r|r|r|r|r|r|r|r|r|}
\hline Japan & 83 & 81 & 95 & 104 & 2330 & 2561 & 3044 & 2622 & 2015 & 12736 \\
\hline USA & 5132 & 4044 & 5865 & 4419 & 5237 & 5157 & 5093 & 4995 & 4681 & 45223 \\
\hline India & 22 & 43 & 80 & 351 & 813 & 1150 & 1900 & 2091 & 828 & 7278 \\
\hline South Korea & 725 & 800 & 870 & 835 & 1052 & 1230 & 1303 & 1348 & 1413 & 9576 \\
\hline Morocco & 0 & 02 & 27 & 30 & 33 & 37 & 30 & 20 & 20 & 199 \\
\hline Poland & 12 & 13 & 19 & 17 & 30 & 40 & 43 & 17 & 17 & 208 \\
\hline Turkey & 01 & 01 & 02 & 01 & 04 & 40 & 59 & 123 & 123 & 354 \\
\hline Total & $\mathbf{2 5 2 8 5}$ & $\mathbf{2 6 7 9 5}$ & $\mathbf{2 5 7 1 2}$ & $\mathbf{2 1 5 5 4}$ & $\mathbf{1 7 8 6 3}$ & $\mathbf{1 0 1 9 4}$ & $\mathbf{9 5 3 9}$ & $\mathbf{1 0 2 5 0}$ & $\mathbf{9 7 1 4}$ & $\mathbf{1 5 6 9 0 6}$ \\
\hline
\end{tabular}


Table 5-1

Panel B: Measures of macro governance variables for the 63 countries in the study

\begin{tabular}{|c|c|c|c|c|c|c|c|c|c|c|c|}
\hline \multirow[t]{2}{*}{ Country } & \multicolumn{6}{|c|}{ Enforcement } & \multirow[b]{2}{*}{ INS } & \multirow[b]{2}{*}{ POL } & \multirow[b]{2}{*}{ COR } & \multirow[b]{2}{*}{ CUL } & \multirow[b]{2}{*}{ IFRS } \\
\hline & JUD & SEC & MIN & ENF & RLAW & PRESS & & & & & \\
\hline Australia & 6.4 & 6.22 & 5.86 & 6.24 & 1.81 & 1.45 & 1.67 & .85 & 1.99 & 6.08 & 1 \\
\hline Argentina & 2.17 & 4.41 & 3.58 & 4.01 & -.58 & .27 & -.74 & -.03 & -.47 & 3.46 & 0 \\
\hline Austria & 6.06 & 5.80 & 5.86 & 6.23 & 1.87 & 1.55 & 1.53 & 1.04 & 1.99 & 6.09 & 1 \\
\hline Bangladesh & n.a & n.a & n.a & n.a & -.86 & -.52 & -.87 & -1.60 & -1.29 & n.a & 0 \\
\hline Belgium & 5.37 & 5.84 & 5.61 & 6.01 & 1.45 & 1.46 & 1.32 & .74 & 1.40 & 5.40 & 1 \\
\hline Bermuda & n.a & n.a & n.a & n.a & .88 & 1.08 & 1.33 & .81 & 1.27 & n.a & 0 \\
\hline Brazil & 3.14 & 5.14 & 4.80 & 4.79 & -.48 & .37 & .00 & -.09 & -.33 & 3.77 & 0 \\
\hline Canada & 6.01 & 5.64 & 5.63 & 6.07 & 1.85 & 1.46 & 1.53 & .94 & 1.90 & 5.86 & 0 \\
\hline Cayman Island & n.a & n.a & n.a & n.a & 1.15 & .84 & 1.33 & 1.17 & 1.27 & n.a & 0 \\
\hline Chile & 4.25 & 5.98 & 5.27 & 5.53 & 1.15 & 1.15 & 1.41 & .85 & 1.31 & 5.46 & 0 \\
\hline China & 3.43 & 3.42 & 3.61 & 3.84 & -.40 & -1.66 & -.19 & -.37 & -.53 & 3.71 & 0 \\
\hline Colombia & 3.81 & 4.94 & 4.49 & 4.50 & -.64 & -.25 & .10 & -1.62 & -.22 & 4.43 & 0 \\
\hline Czech Rep & 4.10 & 4.90 & 4.13 & 4.93 & .73 & .96 & .95 & .75 & .36 & 3.95 & 1 \\
\hline Denmark & n.a & n.a & n.a & n.a & 2.03 & 1.72 & 1.81 & .82 & 2.39 & n.a & 1 \\
\hline Egypt & 4.86 & 3.93 & 4.51 & 4.62 & .00 & -1.08 & -.44 & -.87 & -.41 & 4.34 & 1 \\
\hline Ecuador & n.a & n.a & n.a & n.a & -.96 & -.35 & -1.06 & -.90 & -.75 & n.a & 0 \\
\hline Finland & 6.43 & 5.82 & 5.88 & 6.22 & 1.95 & 1.63 & 1.70 & 1.47 & 2.57 & 6.63 & 1 \\
\hline Germany & 6.53 & 5.95 & 6.14 & 6.34 & 1.77 & 1.48 & 1.39 & .83 & 1.78 & 6.15 & 1 \\
\hline Greece & n.a & n.a & n.a & n.a & .64 & 1.05 & .79 & .48 & .39 & n.a & 1 \\
\hline Hong Kong & 5.94 & 6.19 & 5.61 & 6.20 & 1.45 & .55 & 1.95 & 1.16 & 1.71 & 5.82 & 1 \\
\hline India & 5.30 & 5.52 & 5.31 & 5.64 & .17 & .35 & -.15 & -.84 & -.21 & 4.19 & 0 \\
\hline Indonesia & 2.97 & 5.58 & 5.74 & 4.52 & -.82 & -.25 & -.26 & -1.17 & -.77 & 3.77 & 0 \\
\hline Ireland & 6.01 & 5.95 & 5.77 & 6.21 & 1.62 & 1.42 & 1.75 & 1.16 & 1.60 & 5.53 & 1 \\
\hline Israel & 6.03 & 5.52 & 5.40 & 5.93 & .69 & .68 & .91 & -1.18 & .83 & 4.88 & 1 \\
\hline Italy & 3.79 & 4.47 & 3.97 & 4.46 & .37 & 1.14 & .84 & .28 & .31 & 4.08 & 1 \\
\hline Japan & 5.51 & 5.24 & 4.98 & 5.23 & 1.40 & .91 & 1.27 & 1.11 & 1.31 & 5.41 & 0 \\
\hline Jordan & n.a & n.a & n.a & n.a & .45 & -.62 & .41 & -.53 & .38 & n.a & 1 \\
\hline Kuwait & 5.23 & 4.42 & 4.40 & 5.32 & .75 & -.36 & .51 & .28 & .67 & 4.72 & 1 \\
\hline Latvia & n.a & n.a & n.a & n.a & .52 & .83 & 1.06 & .81 & .38 & n.a & 1 \\
\hline Luxemburg & n.a & n.a & n.a & n.a & 1.83 & 1.63 & 1.79 & 1.51 & 2.01 & n.a & 1 \\
\hline Malaysia & 5.24 & 5.48 & 5.53 & 5.73 & .58 & -.34 & .67 & .35 & .38 & 5.26 & 0 \\
\hline Mexico & 3.58 & 5.10 & 4.44 & 4.63 & -.49 & .06 & .43 & -.40 & -.35 & 4.35 & 0 \\
\hline Morocco & n.a & n.a & n.a & n.a & -.03 & -.63 & -.15 & -.31 & -.06 & n.a & 0 \\
\hline Netherlands & 6.41 & 5.70 & 5.58 & 6.02 & 1.75 & 1.67 & 1.65 & .77 & 2.05 & 6.15 & 1 \\
\hline New Zealand & n.a & n.a & n.a & n.a & 1.93 & 1.62 & 1.68 & 1.27 & 2.38 & n.a & 1 \\
\hline Nigeria & 3.52 & 5.05 & 4.33 & 4.14 & -1.27 & -.78 & -.89 & $\begin{array}{l}-1.99 \\
\end{array}$ & -1.29 & 3.79 & 0 \\
\hline Norway & 6.09 & 5.81 & 5.76 & 6.06 & 2.02 & 1.64 & 1.34 & 1.21 & 2.13 & 6.18 & 1 \\
\hline Oman & n.a & n.a & n.a & n.a & .71 & -.77 & .75 & .66 & .71 & n.a & 1 \\
\hline Pakistan & 3.51 & 3.96 & 4.97 & 4.92 & -.82 & -1.17 & -.39 & $\begin{array}{l}-1.92 \\
\end{array}$ & -.93 & 4.35 & 0 \\
\hline
\end{tabular}




\begin{tabular}{|c|c|c|c|c|c|c|c|c|c|c|c|}
\hline Paraguay & n.a & n.a & n.a & n.a & -.93 & -.36 & -.68 & -.48 & -1.02 & n.a & 0 \\
\hline Peru & 2.19 & 5.31 & 4.23 & 4.77 & -.75 & .05 & .11 & -.90 & -.35 & 3.99 & 1 \\
\hline Philippines & 3.31 & 4.81 & 4.66 & 4.96 & -.48 & -.18 & -.06 & -1.26 & -.69 & 3.51 & 0 \\
\hline Poland & 3.54 & 4.95 & 4.25 & 4.38 & .25 & .95 & .64 & .22 & .14 & 4.17 & 1 \\
\hline Portugal & n.a & n.a & n.a & n.a & .97 & 1.27 & 1.00 & .85 & 1.11 & n.a & 1 \\
\hline Qatar & n.a & n.a & n.a & n.a & .93 & -.51 & .45 & .86 & .83 & n.a & 1 \\
\hline UAE & 4.98 & 4.80 & 4.64 & 5.20 & .67 & -.78 & .80 & .68 & 1.16 & 5.30 & 1 \\
\hline Russia & 2.70 & 3.57 & 3.14 & 3.94 & -.91 & -.87 & -.45 & -.74 & -.76 & 3.26 & 0 \\
\hline Saudi Arabia & 4.39 & 3.91 & 4.40 & 4.72 & .17 & -1.42 & -.02 & -.65 & .18 & 4.43 & 0 \\
\hline Singapore & 5.60 & 5.99 & 5.55 & 6.10 & 1.82 & -.07 & 1.85 & 1.30 & 2.30 & 6.30 & 1 \\
\hline South Africa & 5.45 & 6.02 & 5.64 & 6.22 & .24 & .60 & .68 & -.07 & .56 & 4.68 & 1 \\
\hline South Korea & 5.13 & 5.92 & 5.12 & 5.42 & .72 & .71 & .70 & .42 & .31 & 5.16 & 0 \\
\hline Spain & 3.76 & 4.93 & 4.61 & 5.25 & 1.10 & 1.05 & 1.06 & .33 & 1.18 & 4.87 & 1 \\
\hline Srilanka & n.a & n.a & n.a & n.a & .01 & -.35 & -.11 & -1.61 & -.29 & n.a & 0 \\
\hline Sweden & 6.16 & 6.26 & 6.37 & 6.32 & 1.86 & 1.55 & 1.44 & 1.13 & 2.24 & 6.45 & 1 \\
\hline Switzerland & 6.30 & 5.85 & 5.34 & 6.13 & 1.96 & 1.72 & 1.45 & 1.40 & 2.19 & 6.17 & 0 \\
\hline Taiwan & n.a & n.a & n.a & n.a & .77 & .79 & .94 & .51 & .53 & n.a & 0 \\
\hline Thailand & 4.72 & 5.26 & 4.88 & 5.02 & .03 & -.50 & .37 & -.99 & -.26 & 4.14 & 0 \\
\hline Turkey & 4.40 & 5.23 & 4.58 & 4.82 & .08 & -.19 & .21 & -.65 & .06 & 4.64 & 0 \\
\hline UK & 6.04 & 5.79 & 5.94 & 6.29 & 1.73 & 1.42 & 1.76 & .46 & 1.86 & 5.83 & 1 \\
\hline USA & 5.06 & 5.52 & 5.50 & 5.79 & 1.57 & 1.08 & 1.47 & .31 & 1.30 & 5.10 & 0 \\
\hline Venezuela & 1.19 & 4.49 & 3.89 & 4.06 & -1.39 & -.58 & -1.35 & -1.24 & -1.05 & 3.31 & 1 \\
\hline Viet Nam & 3.61 & 4.31 & 4.48 & 3.89 & -.43 & -1.45 & -.49 & .42 & -.66 & 4.03 & 0 \\
\hline Mean & 5.09 & 5.41 & 5.26 & 5.56 & 1.07 & .80 & 1.05 & .46 & 1.08 & 5.09 & .24 \\
\hline S.D & .84 & .61 & .57 & .61 & .74 & .82 & .69 & .68 & .87 & .69 & .42 \\
\hline
\end{tabular}

Note: JUD = judicial independence (WEF 2008). SEC = enforcement of securities laws (WEF 2008). MIN = protection of minority shareholders interest $($ WEF 2008). ACC = enforcement of accounting and auditing standards (WEF 2008). RLAW = rule of laws (WB 1999-2007). PRESS $=$ press freedom (WB 1999-2007). INS $=$ regulatory quality (WB 1999-2007). PLO = political stability (WB 1999-2007). COR = control of corruption (WB 1999-2007). CUL = ethical behaviour of firms (WEF 2008). IFRS = a dummy variable takes the value of 1 for a given year after mandatory IFRS adoption and 0 otherwise. 
Table 5-1

Panel C: Measures of micro governance variables for the 63 countries in the study

\begin{tabular}{|c|c|c|c|c|c|c|}
\hline \multirow{2}{*}{ Country } & \multicolumn{6}{|c|}{ Micro governance variables } \\
\hline & BIG4 (\%) & BONUS & IPO & BOD & BIND & OWN \\
\hline Australia & 59 & 05 & .77 & 8.35 & 5.81 & .28 \\
\hline Argentina & 65 & 4.73 & .39 & 3.91 & 4.67 & .55 \\
\hline Austria & 62 & 5.01 & .88 & 10.39 & 5.63 & .51 \\
\hline Bangladesh & 39 & n.a & n.a & 7.82 & 4.93 & .50 \\
\hline Belgium & 53 & 4.94 & .27 & 9.55 & 5.41 & .62 \\
\hline Bermuda & 64 & n.a & n.a & 10.47 & n.a & n.a \\
\hline Brazil & 66 & 4.36 & .71 & 3.51 & 4.63 & .63 \\
\hline Canada & 75 & 5.37 & .27 & 11.72 & 5.57 & .24 \\
\hline Cay. Island & 60 & n.a & n.a & 10.70 & n.a & n.a \\
\hline Chile & 80 & 4.97 & .15 & 5.01 & 5.53 & .38 \\
\hline China & 10 & 4.60 & 1.91 & 5.82 & 4.01 & n.a \\
\hline Colombia & 33 & 3.86 & n.a & 2.85 & 4.85 & .68 \\
\hline Czech Rep & 46 & 4.27 & .20 & 5.48 & 5.03 & n.a \\
\hline Denmark & 84 & n.a & n.a & 7.98 & n.a & .40 \\
\hline Egypt & 24 & 3.79 & .21 & 3.31 & 4.39 & .62 \\
\hline Ecuador & 05 & n.a & n.a & 2.15 & n.a & n.a \\
\hline Finland & 90 & 5.01 & 3.73 & 9.60 & 5.37 & .24 \\
\hline Germany & 55 & 5.60 & .34 & 8.43 & 5.69 & .50 \\
\hline Greece & 25 & n.a & n.a & 8.06 & n.a & .68 \\
\hline Hong Kong & 81 & 5.19 & 3.29 & 12.31 & 5.34 & .54 \\
\hline India & 38 & 4.53 & .52 & 8.80 & 5.03 & .43 \\
\hline Indonesia & 26 & 5.19 & .08 & 5.60 & 5.36 & .62 \\
\hline Ireland & 90 & 4.92 & .80 & 10.13 & 5.50 & .36 \\
\hline Israel & 40 & 5.06 & .12 & 10.87 & 5.23 & .55 \\
\hline Italy & 86 & 4.95 & .39 & 7.28 & 4.32 & .60 \\
\hline Japan & 73 & 4.32 & .43 & 5.92 & 5.15 & .13 \\
\hline Jordan & 28 & n.a & n.a & 10.25 & n.a & n.a \\
\hline Kuwait & 53 & 4.71 & n.a & 7.89 & 4.60 & n.a \\
\hline Latvia & 33 & n.a & n.a & 7.59 & n.a & n.a \\
\hline Luxemburg & 87 & n.a & n.a & 11.65 & n.a & n.a \\
\hline Malaysia & 60 & 5.11 & .16 & 9.47 & 5.39 & .52 \\
\hline Mexico & 72 & 4.74 & .22 & 4.51 & 4.61 & .67 \\
\hline Morocco & 71 & n.a & n.a & 9.04 & n.a & n.a \\
\hline Netherlands & 86 & 5.29 & .71 & 9.16 & 5.62 & .31 \\
\hline New Zeal & 85 & n.a & n.a & 8.19 & n.a & .51 \\
\hline Nigeria & 66 & 3.58 & .37 & 10.33 & 4.97 & .45 \\
\hline Norway & 94 & 4.72 & .96 & 8.40 & 5.55 & .31 \\
\hline
\end{tabular}




\begin{tabular}{|c|c|c|c|c|c|c|}
\hline Oman & 61 & n.a & n.a & 9.83 & n.a & n.a \\
\hline Pakistan & 45 & 3.55 & n.a & 9.23 & 3.57 & .41 \\
\hline Paraguay & 29 & n.a & n.a & 1.50 & n.a & n.a \\
\hline Peru & 55 & 3.94 & n.a & 4.93 & 4.68 & .57 \\
\hline Philippines & 31 & 4.33 & .58 & 13.94 & 4.72 & .51 \\
\hline Poland & 47 & 4.15 & .25 & 5.67 & 4.13 & n.a \\
\hline Portugal & 43 & n.a & n.a & 3.95 & n.a & .59 \\
\hline Qatar & 72 & n.a & n.a & 10.11 & n.a & n.a \\
\hline UAE & 74 & 4.33 & 1.06 & 9.37 & 4.59 & n.a \\
\hline Russia & 56 & 4.57 & 1.74 & 3.78 & 4.96 & n.a \\
\hline Saudi Arabia & 55 & 4.33 & .77 & 9.13 & 4.73 & n.a \\
\hline Singapore & 71 & 5.18 & 1.76 & 9.69 & 5.61 & .53 \\
\hline South Africa & 70 & 5.67 & .34 & 10.00 & 5.73 & .52 \\
\hline South Korea & 36 & 5.41 & .63 & 10.26 & 5.21 & .20 \\
\hline Spain & 86 & 4.88 & .31 & 4.86 & 5.00 & .50 \\
\hline Srilanka & 87 & n.a & n.a & 8.96 & n.a & .61 \\
\hline Sweden & 86 & 5.16 & .41 & 8.36 & 6.09 & .28 \\
\hline Switzerland & 90 & 5.61 & .96 & 8.59 & 5.41 & .48 \\
\hline Taiwan & 85 & n.a & 1.02 & 12.25 & 4.83 & .48 \\
\hline Thailand & 72 & 4.37 & 1.02 & 12.25 & 4.83 & .48 \\
\hline Turkey & 32 & 3.62 & .21 & 7.26 & 4.34 & .50 \\
\hline UK & 63 & 5.36 & .78 & 9.37 & 5.92 & .15 \\
\hline USA & 61 & 5.51 & .34 & 10.00 & 5.47 & .12 \\
\hline Venezuela & 88 & 4.47 & n.a & 4.14 & 4.29 & .49 \\
\hline Viet Nam & 38 & 4.30 & .19 & 6.62 & 4.46 & n.a \\
\hline Mean & 54 & 5.09 & .64 & 8.54 & 5.27 & .26 \\
\hline S.D & .498 & .51 & .69 & 5.51 & .46 & .17 \\
\hline
\end{tabular}

Note: BIG4 = equals 1 if the firm audited by one of the BIG 4 and otherwise 0. BONUS $=$ extent of incentives based compensation (WEF 2008). IPO = initial public offerings (WEF 2008). $\mathbf{B O D}=$ no of directors on the board of a firm. BIND = board effectiveness from the (WEF 2008). OWN = ownership concentration (La Porta et al. 2006). 
Table 5-1

Panel D: Pearson correlation on macro and micro governance variables with DACCR $(\mathrm{N}=63)$

\begin{tabular}{|c|c|c|c|c|c|c|c|c|c|c|c|c|c|c|c|c|c|}
\hline & SEC & MIN & ACC & RLAW & PRESS & POL & COR & CUL & IPO & LEV & BONUS & IFRS & BIG4 & BOD & BIND & OWN & DACRR \\
\hline JUD & $\begin{array}{c}.681 \\
(<.01)\end{array}$ & $\begin{array}{c}.754 \\
(<.01)\end{array}$ & $\begin{array}{c}.823 \\
(<.01)\end{array}$ & $\begin{array}{c}.758 \\
(<.01)\end{array}$ & $\begin{array}{c}.605 \\
(<.01)\end{array}$ & $\begin{array}{c}.542 \\
(<.01)\end{array}$ & $\begin{array}{c}.688 \\
(<.01)\end{array}$ & $\begin{array}{c}.863 \\
(<.01)\end{array}$ & $\begin{array}{l}-.125 \\
(<.01)\end{array}$ & $\begin{array}{c}.020 \\
(<.01)\end{array}$ & $\begin{array}{c}.337 \\
(<.01)\end{array}$ & $\begin{array}{c}.243 \\
(<.01)\end{array}$ & $\begin{array}{c}.176 \\
(<.01)\end{array}$ & $\begin{array}{c}.153 \\
(<.01)\end{array}$ & $\begin{array}{c}.741 \\
(<.01)\end{array}$ & $\begin{array}{c}-298 \\
(<.01)\end{array}$ & $\begin{array}{l}-.076 \\
(<.01)\end{array}$ \\
\hline SEC & & $\begin{array}{c}.855 \\
(<.01)\end{array}$ & $\begin{array}{c}.870 \\
(<.01)\end{array}$ & $\begin{array}{c}.652 \\
(<.01)\end{array}$ & $\begin{array}{c}.755 \\
(<.01)\end{array}$ & $\begin{array}{c}.424 \\
(<.01)\end{array}$ & $\begin{array}{c}.619 \\
(<.01)\end{array}$ & $\begin{array}{c}.717 \\
(<.01)\end{array}$ & $\begin{array}{l}-.167 \\
(<.01)\end{array}$ & $\begin{array}{c}.038 \\
(<.01)\end{array}$ & $\begin{array}{c}.560 \\
(<.01)\end{array}$ & $\begin{array}{c}.169 \\
(<.01)\end{array}$ & $\begin{array}{c}.153 \\
(<.01)\end{array}$ & $\begin{array}{l}.190 \\
(<.01)\end{array}$ & $\begin{array}{c}.867 \\
(<.01)\end{array}$ & $\begin{array}{l}-.195 \\
(<.01)\end{array}$ & $\begin{array}{l}-.071 \\
(<.01)\end{array}$ \\
\hline MIN & & & $\begin{array}{c}.929 \\
(<.01)\end{array}$ & $\begin{array}{c}.725 \\
(<.01)\end{array}$ & $\begin{array}{c}.733 \\
(<.01)\end{array}$ & $\begin{array}{c}.397 \\
(<.01)\end{array}$ & $\begin{array}{c}.713 \\
(<.01)\end{array}$ & $\begin{array}{c}.742 \\
(<.01)\end{array}$ & $\begin{array}{c}.341 \\
(<.01)\end{array}$ & $\begin{array}{c}.037 \\
(<.01)\end{array}$ & $\begin{array}{c}.574 \\
(<.01)\end{array}$ & $\begin{array}{c}.177 \\
(<.01)\end{array}$ & $\begin{array}{c}.192 \\
(<.01)\end{array}$ & $\begin{array}{c}.198 \\
(<.01)\end{array}$ & $\begin{array}{c}.905 \\
(<.01)\end{array}$ & $\begin{array}{c}-274 \\
(<.01)\end{array}$ & $\begin{array}{l}-.104 \\
(<.01)\end{array}$ \\
\hline ACC & & & & $\begin{array}{c}.804 \\
(<.01)\end{array}$ & $\begin{array}{c}.771 \\
(<.01)\end{array}$ & $\begin{array}{c}.470 \\
(<.01)\end{array}$ & $\begin{array}{c}.785 \\
(<.01)\end{array}$ & $\begin{array}{c}.801 \\
(<.01)\end{array}$ & $\begin{array}{l}-139 \\
(<.01)\end{array}$ & $\begin{array}{c}.038 \\
(<.01)\end{array}$ & $\begin{array}{c}.631 \\
(<.01)\end{array}$ & $\begin{array}{c}.229 \\
(<.01)\end{array}$ & $\begin{array}{c}.223 \\
(<.01)\end{array}$ & $\begin{array}{c}.224 \\
(<.01)\end{array}$ & $\begin{array}{c}.909 \\
(<.01)\end{array}$ & $\begin{array}{l}-.3016 \\
(<.01)\end{array}$ & $\begin{array}{l}-.112 \\
(<.01)\end{array}$ \\
\hline RLAW & & & & & $\begin{array}{c}.822 \\
(<.01)\end{array}$ & $\begin{array}{c}.773 \\
(<.01)\end{array}$ & $\begin{array}{c}.965 \\
(<.01)\end{array}$ & $\begin{array}{c}.852 \\
(<.01)\end{array}$ & $\begin{array}{l}-168 \\
(<.01)\end{array}$ & $\begin{array}{c}.003 \\
.265)\end{array}$ & $\begin{array}{c}.611 \\
(<.01)\end{array}$ & $\begin{array}{c}.126 \\
(<.01)\end{array}$ & $\begin{array}{c}.304 \\
(<.01)\end{array}$ & $\begin{array}{l}.165 \\
(<.01)\end{array}$ & $\begin{array}{c}.820 \\
(<.01)\end{array}$ & $\begin{array}{l}-.623 \\
(<.01)\end{array}$ & $\begin{array}{l}-166 \\
(<.01)\end{array}$ \\
\hline PRESS & & & & & & $\begin{array}{c}.583 \\
(<.01)\end{array}$ & $\begin{array}{c}.800 \\
(<.01)\end{array}$ & $\begin{array}{c}.646 \\
(<.01)\end{array}$ & $\begin{array}{c}-310 \\
(<.01)\end{array}$ & $\begin{array}{c}.045 \\
(<.01)\end{array}$ & $\begin{array}{c}.574 \\
(<.01)\end{array}$ & $\begin{array}{c}.051 \\
(<.01)\end{array}$ & $\begin{array}{c}.272 \\
(<.01)\end{array}$ & $\begin{array}{c}.128 \\
(<.01)\end{array}$ & $\begin{array}{c}.803 \\
(<.01)\end{array}$ & $\begin{array}{c}-.610 \\
(<.01)\end{array}$ & $\begin{array}{c}.132 \\
(<.01)\end{array}$ \\
\hline POL & & & & & & & $\begin{array}{c}.768 \\
(<.01)\end{array}$ & $\begin{array}{c}.742 \\
(<.01)\end{array}$ & $\begin{array}{c}.042 \\
(<.01)\end{array}$ & $\begin{array}{c}.035 \\
(<.01)\end{array}$ & $\begin{array}{c}.364 \\
(<.01)\end{array}$ & $\begin{array}{c}.065 \\
(<.01)\end{array}$ & $\begin{array}{c}324 \\
(<.01)\end{array}$ & $\begin{array}{l}.001 \\
.844)\end{array}$ & $\begin{array}{c}.552 \\
(<.01)\end{array}$ & $\begin{array}{c}-.443 \\
(<.01)\end{array}$ & $\begin{array}{l}-.098 \\
(<.01)\end{array}$ \\
\hline $\begin{array}{l}\mathrm{COR} \\
\end{array}$ & & & & & & & & $\begin{array}{c}.841 \\
(<.01)\end{array}$ & $\begin{array}{l}-.132 \\
(<.01)\end{array}$ & $\begin{array}{c}.001 \\
(.713)\end{array}$ & $\begin{array}{c}.604 \\
(<.01)\end{array}$ & $\begin{array}{c}.154 \\
(<.01)\end{array}$ & $\begin{array}{c}.344 \\
(<.01)\end{array}$ & $\begin{array}{c}.139 \\
(<.01)\end{array}$ & $\begin{array}{c}.812 \\
(<.01)\end{array}$ & $\begin{array}{c}-.528 \\
(<.01)\end{array}$ & $\begin{array}{l}.157 \\
(<.01)\end{array}$ \\
\hline CUL & & & & & & & & & $\begin{array}{c}-.068 \\
(<.01)\end{array}$ & $\begin{array}{c}-.012 \\
(<.01)\end{array}$ & $\begin{array}{c}.425 \\
(<.01)\end{array}$ & $\begin{array}{c}.264 \\
(<.01)\end{array}$ & $\begin{array}{c}.284 \\
(<.01)\end{array}$ & $\begin{array}{c}.115 \\
(<.01)\end{array}$ & $\begin{array}{c}793 \\
(<.01)\end{array}$ & $\begin{array}{c}-325 \\
(<.01)\end{array}$ & $\begin{array}{l}.084 \\
(<.01)\end{array}$ \\
\hline IPO & & & & & & & & & & $\begin{array}{c}-.026 \\
(<.01)\end{array}$ & $\begin{array}{c}.003 \\
(.260)\end{array}$ & $\begin{array}{c}.174 \\
(<.01)\end{array}$ & $\begin{array}{c}-.069 \\
(<.01)\end{array}$ & $\begin{array}{c}-.017 \\
(<.01)\end{array}$ & $\begin{array}{c}-.260 \\
(<.01)\end{array}$ & $\begin{array}{c}.100 \\
(<.01)\end{array}$ & $\begin{array}{c}.024 \\
(<.01)\end{array}$ \\
\hline LEV & & & & & & & & & & & $\begin{array}{l}.005 \\
(.054)\end{array}$ & $\begin{array}{c}.017 \\
(<.01)\end{array}$ & $\begin{array}{c}.062 \\
(<.01)\end{array}$ & $\begin{array}{c}.073 \\
(<.01)\end{array}$ & $\begin{array}{c}.018 \\
(<.01)\end{array}$ & $\begin{array}{c}.048 \\
(<.01)\end{array}$ & $\begin{array}{c}.149 \\
(<.01)\end{array}$ \\
\hline BONUS & & & & & & & & & & & & $\begin{array}{c}.036 \\
(<.01) \\
\end{array}$ & $\begin{array}{c}.091 \\
(<.01)\end{array}$ & $\begin{array}{c}.248 \\
(<.01)\end{array}$ & $\begin{array}{c}.671 \\
(<.01)\end{array}$ & $\begin{array}{c}-.420 \\
(<.01)\end{array}$ & $\begin{array}{l}.165 \\
(<.01) \\
\end{array}$ \\
\hline IFRS & & & & & & & & & & & & & $\begin{array}{c}.033 \\
(<.01)\end{array}$ & $\begin{array}{c}.009 \\
(<.01)\end{array}$ & $\begin{array}{c}.184 \\
(<.01)\end{array}$ & $\begin{array}{c}.230 \\
(<.01)\end{array}$ & $\begin{array}{c}.010 \\
(<.01)\end{array}$ \\
\hline BIG4 & & & & & & & & & & & & & & $\begin{array}{c}.164 \\
(<.01)\end{array}$ & $\begin{array}{c}.254 \\
(<.01)\end{array}$ & $\begin{array}{c}-.101 \\
(<.01)\end{array}$ & $\begin{array}{c}.033 \\
(<.01)\end{array}$ \\
\hline BOD & & & & & & & & & & & & & & & $\begin{array}{c}.174 \\
(<.01)\end{array}$ & $\begin{array}{c}-.074 \\
(<.01)\end{array}$ & $\begin{array}{c}.031 \\
(<.01)\end{array}$ \\
\hline BIND & & & & & & & & & & & & & & & & $\begin{array}{l}-.437 \\
(<.01)\end{array}$ & $\begin{array}{l}-.126 \\
(<.01)\end{array}$ \\
\hline OWN & & & & & & & & & & & & & & & & & $\begin{array}{c}.169 \\
(<.01)\end{array}$ \\
\hline
\end{tabular}

Note: p-values are in parenthesis.

JUD $=$ judicial independence (WEF 2008). SEC $=$ enforcement of securities laws (WEF 2008). $\mathbf{M I N}=$ protection of minority shareholders interest $($ WEF 2008). ACC $=$ enforcement of accounting and auditing standards (WEF 2008). RLAW = rule of laws (WB 1999-2007). PRESS = press freedom (WB 1999-2007). REG $=$ regulatory quality $($ WB 1999-2007). PLO $=$ political stability $($ WB 1999-2007). COR $=$ control of corruption (WB 1999-2007). CUL = ethical behaviour (WEF 2008). BIG4 = indicator variable with the value of 1 if the firm audited by one of the BIG 4 and otherwise 0. BONUS = extent of incentive based compensation (WEF 2008). IFRS = A dummy variable takes the value of 1 for a given year after mandatory IFRS adoption and 0 otherwise. IPO $=$ initial public offerings (WEF 2008). BOD $=$ no of directors on the board of a firm. BIND $=$ board effectiveness $($ WEF 2008). OWN $=$ ownership concentration (La Porta et al. 2006). DACCR is the signed discretionary accruals. 
Table 5-2

\section{Descriptive statistics}

\begin{tabular}{|l|c|c|c|c|c|}
\hline \multicolumn{1}{|c|}{ Variables } & Mean & Std. Dev. & $\mathbf{2 5}^{\text {th }}$ Percentile & Median & $\mathbf{7 5}^{\text {th }}$ Percentile \\
\hline DACCR & -.1678 & .24275 & -.2775 & -.1674 & -.0471 \\
\hline SIZE & 5.1092 & .88551 & 4.4922 & 5.0923 & 5.7102 \\
\hline LEV & .4732 & .98672 & .0102 & .1805 & .6071 \\
\hline GWTH & -.0025 & .59483 & -.0148 & .0725 & .1577 \\
\hline CFO & .0342 & .19394 & -.0131 & .0561 & .1240 \\
\hline CAP & .3367 & .24780 & .1295 & .2848 & .4975 \\
\hline LOSS & .31 & .46 & 0 & 0 & 1 \\
\hline
\end{tabular}

Note: DACCR = signed discretionary accruals. SIZE is the natural logarithm of total assets in \$ thousands for firm i in year t. LEV is total liabilities / total equities for firm i in year t. GWTH is return on equity, defined as the net income in year t scaled by total equity in year t. CFO is the operating cash flows for firm i in year t scaled by lagged total assets. CAP is the non-current (fixed) assets in year $\mathrm{t} /$ Total assets in year t. LOSS takes the value of 1 if firm i reports income before extraordinary items in the previous year negative and 0 otherwise. 


\begin{tabular}{|c|c|}
\hline Label & Definition \\
\hline Aggressive accounting & $\begin{array}{l}\text { A forceful and intentional choice and application of accounting } \\
\text { principles done in an effort to achieve desired result. Typically } \\
\text { higher current earnings, whether the practices followed are in } \\
\text { accordance with GAAP or not. }\end{array}$ \\
\hline Earnings management & $\begin{array}{l}\text { The active manipulation of earnings toward a pre-determined } \\
\text { target, which may be set by management, a forecast made by } \\
\text { analyst, or an amount that is consistent with a smoother, more } \\
\text { sustainable earnings stream. }\end{array}$ \\
\hline Income smoothing & $\begin{array}{l}\text { A form of earnings management designed to remove peaks and valleys } \\
\text { from a normal earnings series, including steps to reduce and "store" } \\
\text { profits during good years for use during slower years. }\end{array}$ \\
\hline Fraudulent financial reporting & $\begin{array}{l}\text { Intentional misstatements or omission of amounts or disclosures in } \\
\text { financial statements, done to deceive financial statement users, which } \\
\text { are determined to be fraudulent by an administrative, civil, or } \\
\text { criminal proceeding. }\end{array}$ \\
\hline Creative accounting practices & $\begin{array}{l}\text { Any and all steps used to play the financial number game, including } \\
\text { the aggressive choice and application of accounting principles, } \\
\text { fraudulent financial reporting, and any steps taken towards earnings } \\
\text { management or income smoothing. }\end{array}$ \\
\hline
\end{tabular}

Source: Mulford and Comiskey (2002: 3) 
Appendix - C

Brief sketch of empirical studies on earnings management

(Source: Own works based on S.P. Kothari (2001) and other empirical studies)

\begin{tabular}{|c|c|c|c|c|}
\hline$\underline{\underline{\text { SL }}}$ & Author (s) & Motivation & $\underline{\text { Sample }}$ & $\underline{\text { Results }}$ \\
\hline 01 & $\begin{array}{l}\text { Copeland and Wojdak } \\
\text { (1969) }\end{array}$ & $\begin{array}{l}\text { Accounting for merger to } \\
\text { maximize future income. }\end{array}$ & $\begin{array}{l}\text { Gagnon's } 55-58 \text { data, plus } 118 \text { recent } \\
\text { NYSE mergers. }\end{array}$ & $\begin{array}{l}\text { Strong support for the hypothesis of income maximization through a massive use of the pooling } \\
\text { method. }\end{array}$ \\
\hline 02 & $\begin{array}{l}\text { Anderson } \\
\text { Louderback (1975) }\end{array}$ & Purchase - pooling decision. & 114 mergers of the NYSE & No significant decline of the maximizing behavior after APB 16 \\
\hline 03 & Bermser (1975) & Use of accounting changes for EM & $\begin{array}{l}250 \text { largest U.S. firms from Fortune } \\
\text { sample. }\end{array}$ & Changing firms have a poorer pattern of profit \\
\hline 04 & Healy (1985) & $\begin{array}{l}\text { Effect on bonus plans on } \\
\text { accounting choice. }\end{array}$ & 94 firms for 239 firms' year. & $\begin{array}{l}\text { If the profit is too low, managers will take a bath otherwise they will pick income - increasing or } \\
\text { decreasing procedures }\end{array}$ \\
\hline 05 & DeAngelo (1986) & $\begin{array}{l}\text { Proxy contest and management } \\
\text { buyout. }\end{array}$ & $\begin{array}{l}64 \text { NYSE and American SEC proposing a } \\
\text { management buyout (1973 - 1982) }\end{array}$ & The empirical evidence does not support the hypothesis \\
\hline 06 & $\begin{array}{l}\text { McNichols and Wilson } \\
\text { (1988) }\end{array}$ & $\begin{array}{l}\text { Decrease the variance of earnings } \\
\text { when the profit is too low, } \\
\text { managers will choose to take a } \\
\text { bath. }\end{array}$ & $\begin{array}{l}138 \text { firms from the printing and } \\
\text { publishing industry giving a total of } 2038 \\
\text { firm - years. }\end{array}$ & $\begin{array}{l}\text { Results are consistent with the income decreasing hypothesis although not with the smoothing } \\
\text { hypothesis. }\end{array}$ \\
\hline 07 & $\begin{array}{l}\text { Dechow and Sloan } \\
(1991)\end{array}$ & $\begin{array}{l}\text { CEO situation and } \mathrm{R} \quad \& \mathrm{D} \\
\text { expenditure. }\end{array}$ & $\begin{array}{l}\text { Compustat firms in specific SIC codes - } \\
405 \text { firms. }\end{array}$ & Positive evidence of income increasing accounting choices by CEO. \\
\hline 08 & Jones (1991) & $\begin{array}{l}\text { EM during an enquiry of the } \\
\text { International Trade. }\end{array}$ & 23 firms in 5 industrial sectors & Managers make income decreasing accounting choices during investigation. \\
\hline 09 & Aharony et al. (1993) & EM in an IPO context & $\begin{array}{l}229 \text { industrial firms }(1985-87) \text { on a } \\
\text { population of } 1162 \text { U.S. firms }\end{array}$ & No evidence of manipulation through the accruals. \\
\hline 10 & Bartov (1993) & $\begin{array}{lll}\begin{array}{l}\text { Income } \\
\text { disposals. }\end{array} & \text { recognition } & \text { from } \\
\end{array}$ & $\begin{array}{l}653 \text { firm - year observations from } \\
\text { Compustat, classified by industrial sector. }\end{array}$ & Highly geared and low income firms have significantly higher revenues from asset sales. \\
\hline
\end{tabular}




\begin{tabular}{|c|c|c|c|c|}
\hline 11 & Dempsey et al. (1993) & ownership structure and EM & 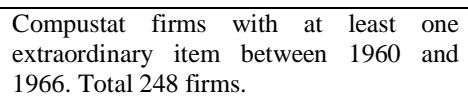 & When management and ownership are separated, high level of EM through extraordinary items \\
\hline 12 & Pourciau (1993) & $\begin{array}{l}\text { The effect of non-routine top } \\
\text { executive changes on accounting }\end{array}$ & $\begin{array}{l}73 \text { firms from disclosure having } \\
\text { experience a non-routine CEO change. }\end{array}$ & $\begin{array}{l}\text { As expected new CEO decrease income in their first year (big bath), unexpectedly leaving CEO do } \\
\text { the same in their last year. }\end{array}$ \\
\hline 13 & DeAngelo et al. (1994) & $\begin{array}{l}\text { Potential problems to comply with } \\
\text { debt covenant dealt through } \\
\text { dividend cuts. }\end{array}$ & $\begin{array}{l}76 \text { firms from the NYSE with three years } \\
\text { of losses within } 1980-85 \text {. }\end{array}$ & No real significant income increasing procedures. \\
\hline 14 & $\begin{array}{l}\text { DeFond and Jiambalvo } \\
\text { (1994) }\end{array}$ & $\begin{array}{l}\text { Possibility of a default of the debt } \\
\text { covenant. }\end{array}$ & $\begin{array}{l}94 \text { firms from the NAARS database } \\
\text { disclosing a violation between 1985and } \\
1988 \text {. }\end{array}$ & EM occurs the year before the default becomes publicly knows. \\
\hline 15 & Friedlan (1994) & EM in a IPO context & 277 IPO firms from 1981 to 1984 & Income increasing procedures just before the IPO \\
\hline 16 & Sweeney (1994) & Debt covenant default possibilities & $\begin{array}{l}130 \text { firms first times violators }(1980- \\
1989) \text { with data on Compustat. }\end{array}$ & Significant manipulation when in danger of defaulting. \\
\hline 17 & Dechow et al. (1995) & $\begin{array}{l}\text { To test the validity of available } \\
\text { models in detecting EM. }\end{array}$ & $\begin{array}{l}4 \text { samples: } 2 \text { random of } 1000 \text { each, } 1 \text { from } \\
\text { firms having extreme performances, and } 1 \\
\text { of } 36 \text { firms prosecuted by the SEC. }\end{array}$ & Jones modified is the best model although none is really complete. \\
\hline 18 & Gaver et al.(1995) & $\begin{array}{l}\text { Effect on bonus plan on } \\
\text { accounting choices }\end{array}$ & 102 firm between 1980 and 1990 & No big bath they increase the profit when too low and decrease it when too high \\
\hline 19 & Holthausen et al. (1995) & $\begin{array}{l}\text { Effect on bonus plan on } \\
\text { accounting choices }\end{array}$ & 567 firms between 1987 and 1993 & Income reducing procedure at the top \\
\hline 20 & Kinnunen et al. (1995) & EM and economy sectors & 37 listed firm, 17 core and 20 peripheral & Opportunity for and use of EM is greater in the core sector, and the sector is making a difference. \\
\hline 21 & Neill et al. (1995) & EM in IPO context & Population = 2609 IPOs $(1975-1984)$. & Relationship between the size of the proceeds and the liberality of accounting policies. \\
\hline 22 & Beneish (1997) & $\begin{array}{l}\text { Distinguish GAAP violators from } \\
\text { simply aggressive accruals. }\end{array}$ & $\begin{array}{l}\text { Experimental : } 64 \text { firms charged by the } \\
\text { SEC } \\
\text { Control group: Firms with high accruals } \\
2118 \text { firms. }\end{array}$ & The model can detect the possibility of opportunistic reporting among firms with large accruals. \\
\hline
\end{tabular}




\begin{tabular}{|c|c|c|c|c|}
\hline 23 & $\begin{array}{l}\text { Burgstahler and Dichev } \\
(1997)\end{array}$ & $\begin{array}{l}\text { EM around profit }=0 \text { or a negative } \\
\text { value }\end{array}$ & 64446 observation-years (1977 - 94) & Strong evidence of EM when earnings decrease or are negative. \\
\hline 24 & Black et al. (1998) & $\begin{array}{l}\text { EM through asset disposals and } \\
\text { accounting regulation in an } \\
\text { international context. }\end{array}$ & $\begin{array}{l}\text { From data available in Global Vantage. } \\
750 \text { firms from Australia, New Zealand } \\
\text { and U.K, for a total of } 1199 \text { firm- years. }\end{array}$ & $\begin{array}{l}\text { Testing of asset revaluation. No evidence of EM in Australia and New Zealand but strong one in } \\
\text { the U.K. }\end{array}$ \\
\hline 25 & Cormier et al.(1998) & $\begin{array}{l}\text { Firms in financial distress and } \\
\text { takeover attempts }\end{array}$ & $\begin{array}{l}60 \text { Swiss firms on five years on the total } \\
\text { of } 172 \text { listed Swiss firms. }\end{array}$ & $\begin{array}{l}\text { Principles of the agency theory (or positive accounting theory) are applicable in Switzerland as } \\
\text { well as in Anglo-Saxon countries. }\end{array}$ \\
\hline 26 & Han and Wang (1998) & EM to decrease political visibility & 76 firms in predetermined SIC codes & Evidence that oil companies used income decreasing procedures during the Gulf war \\
\hline 27 & $\begin{array}{l}\text { Labelle and Thibault } \\
(1998)\end{array}$ & Environmental crises & $\begin{array}{l}\text { Sample of } 10 \text { firms having known as } \\
\text { environmental crises reported on the front } \\
\text { page of the New - York Times }\end{array}$ & No evidence of earnings management after the issuing. \\
\hline 28 & Teoh et al. $\left(1998_{\mathrm{b}}\right)$ & $\begin{array}{l}\text { IPOs, increased asymmetry of } \\
\text { information }\end{array}$ & 1649 IPO firms (1980 - 92) & Positive evidence of Earnings management immediately after the issuing. \\
\hline 29 & Beneish $\left(1999_{a}\right)$ & $\begin{array}{l}\text { Consequences of earnings } \\
\text { overstatement. }\end{array}$ & $\begin{array}{l}\text { Experimental : } 64 \text { firms charged by the } \\
\text { SEC } \\
\text { Control group: Firms with high accruals } \\
2,118 \text { firms. }\end{array}$ & $\begin{array}{l}\text { Managers are more likely to sell their holdings and exercise stock appreciation rights in periods } \\
\text { when earnings are overstated. }\end{array}$ \\
\hline 30 & Beneish $\left(1999_{b}\right)$ & Detection of earnings manipulation & $\begin{array}{l}74 \text { companies and all Compustat } \\
\text { companies matched by two - digit SIC } \\
\text { numbers. Data available for } 1982-92 \\
\text { period }\end{array}$ & Identification of half of the companies involved in earnings manipulation. \\
\hline 31 & Degeorge et al.(1999) & Manage investors impression & $\begin{array}{l}\text { Quarterly data on } 5387 \text { firms from } 1974 \text { to } \\
1996\end{array}$ & $\begin{array}{l}\text { Firms are using EM to avoid reporting earnings below some threshold identified empirically in the } \\
\text { study }\end{array}$ \\
\hline 32 & $\begin{array}{l}\text { Erickson and Wang } \\
(1999)\end{array}$ & $\begin{array}{l}\text { Increasing stock value prior to a } \\
\text { stock merger }\end{array}$ & 55 firms from 24 industries & Income increasing procedures are found just before the merger \\
\hline 33 & $\begin{array}{l}\text { Jeter and Shivakumar } \\
(1999)\end{array}$ & $\begin{array}{l}\text { Improve the methodology to detect } \\
\text { event- specific EM }\end{array}$ & $\begin{array}{l}1000 \text { firms periods in each cash flow } \\
\text { quartile }\end{array}$ & The Jones model is not well specified or extreme cash flow \\
\hline 34 & Kasznik (1999) & $\begin{array}{l}\text { Managers will try to present } \\
\text { earnings to meet or beat the } \\
\text { analysts' forecasts. }\end{array}$ & $\begin{array}{l}499 \text { management earnings forecasts from } \\
\text { Lexis news. }\end{array}$ & Found evidence of EM to align the presented and the forecasted earnings \\
\hline
\end{tabular}




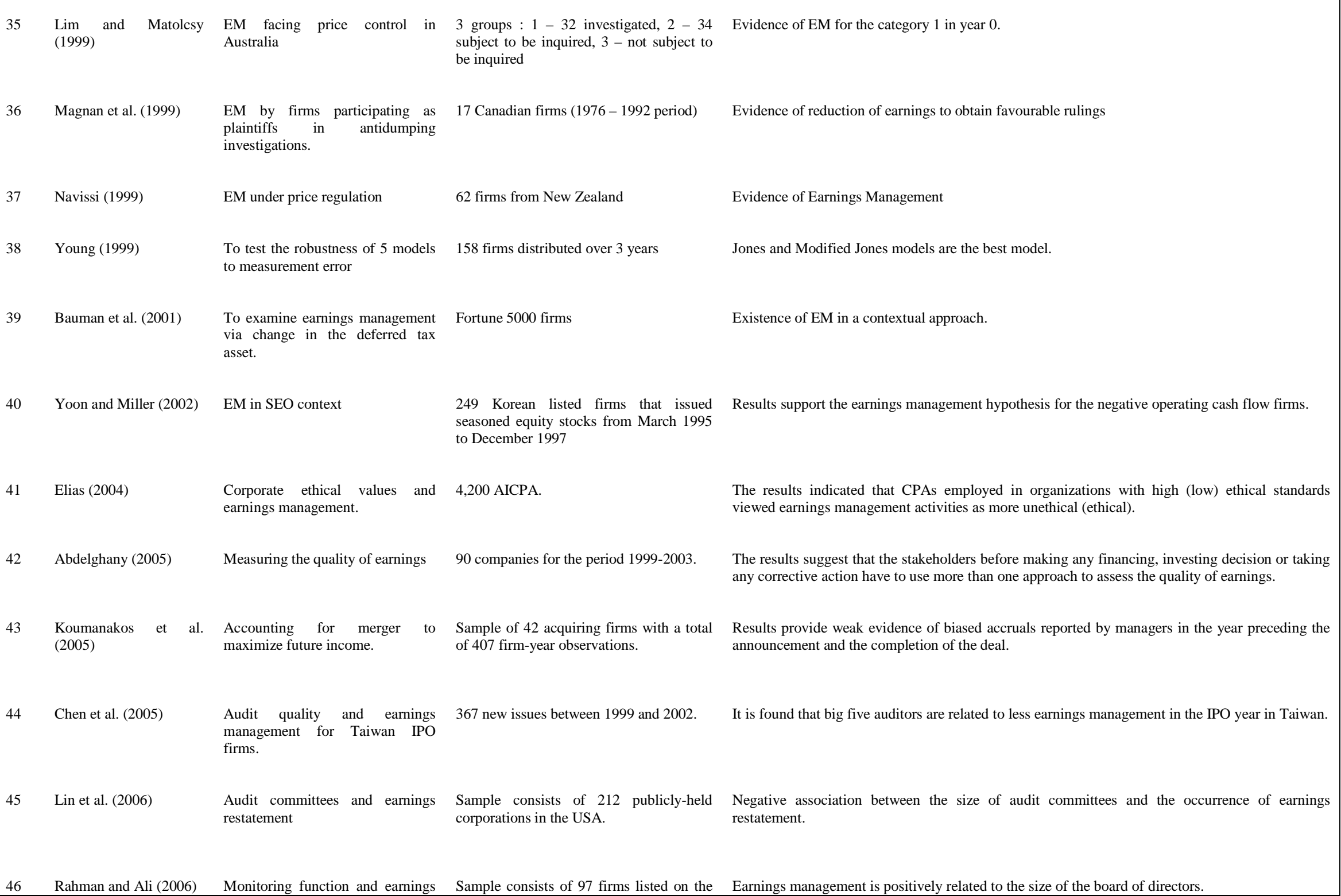




\begin{tabular}{|c|c|c|c|c|}
\hline & & management. & $\begin{array}{l}\text { Main Board of Bursa Malaysia over the } \\
\text { period } 2002-2003 \text {. }\end{array}$ & \\
\hline 47 & Roychowdhury (2006) & $\begin{array}{l}\text { Real activities manipulation in } \\
\text { large samples. }\end{array}$ & $\begin{array}{l}\text { Compustat database between } 1987 \text { and } \\
2001\end{array}$ & $\begin{array}{l}\text { This study suggesting price discounts to temporarily increase sales, overproduction to report lower } \\
\text { cost of goods sold, and reduction of discretionary expenditures to improve reported margins. }\end{array}$ \\
\hline 48 & Lang et al. (2006) & $\begin{array}{l}\text { To compare US firms' earnings } \\
\text { with reconciled earnings for cross- } \\
\text { listed non-US firms. }\end{array}$ & $\begin{array}{l}\text { Sample comprises } 698 \text { non-US firm years } \\
1991 \text { to } 2002\end{array}$ & $\begin{array}{l}\text { Relative to the US firms, cross-listed firms report reconciled earnings that are smoother compared } \\
\text { to cash flows. }\end{array}$ \\
\hline 49 & Petrovits (2006) & $\begin{array}{l}\text { Corporate philanthropy programs } \\
\text { to achieve financial reporting } \\
\text { objectives. }\end{array}$ & $\begin{array}{l}\text { Corporate foundation data from the } \\
\text { foundations 990-PF, Compustat and } \\
\mathrm{I} / \mathrm{B} / \mathrm{E} / \mathrm{S} \text { database. }\end{array}$ & $\begin{array}{l}\text { Firms reporting small earnings increases make income-increasing discretionary foundation funding } \\
\text { choices. }\end{array}$ \\
\hline 50 & Hribar et al. (2006) & $\begin{array}{l}\text { Stock repurchases to meet or beat } \\
\text { analysts' earnings per share (EPS) } \\
\text { forecasts. }\end{array}$ & 32,536 firms year from 1988 to 2001 & $\begin{array}{l}\text { A disproportionately large number of accretive stocks repurchases among firms that would have } \\
\text { missed analysts' forecasts without the repurchase. }\end{array}$ \\
\hline 51 & $\begin{array}{l}\text { Asthana and Zhang } \\
(2006)\end{array}$ & $\begin{array}{l}\text { Firms' and industry's R\&D } \\
\text { intensity on persistence of } \\
\text { abnormal earnings. }\end{array}$ & 2,524 firms year for the period $1982-2001$ & $\begin{array}{l}\text { Result suggests that firms' and industries' R\&D intensities are both positively correlated with } \\
\text { persistence of abnormal earnings. }\end{array}$ \\
\hline 52 & $\begin{array}{l}\text { Belkaoui and AlNajjar } \\
\text { (2006) }\end{array}$ & $\begin{array}{l}\text { Determinants of earnings opacity } \\
\text { internationally. }\end{array}$ & A sample of 34 countries & $\begin{array}{l}\text { Earnings opacity internationally is negatively related to the levels of economic freedom and quality } \\
\text { of life, and positively related to rule of law, economic growth and level of corruption. }\end{array}$ \\
\hline 53 & Weber (2006) & $\begin{array}{l}\text { Executive wealth sensitivity to } \\
\text { stock price fluctuations serves as } \\
\text { an incentive for earnings } \\
\text { management. }\end{array}$ & $\begin{array}{l}\text { A sample of } 410 \text { chief executive officers } \\
\text { (CEOs) from } 475 \text { randomly selected } \\
\text { Standard and Poor's (S\&P) } 1500 \text { firms }\end{array}$ & $\begin{array}{l}\text { CEO wealth sensitivity is positively associated with abnormal accrual usage and the relation is } \\
\text { consistent with income-smoothing. }\end{array}$ \\
\hline 54 & Ebrahim (2007) & $\begin{array}{l}\text { Earnings management behaviour } \\
\text { and board activity. }\end{array}$ & $\begin{array}{l}\text { SIC codes from } 2,000 \text { to } 3,999 \text { as listed in } \\
\text { COMPUSTAT files in } 2002 \text { with fiscal } \\
\text { year }\end{array}$ & Earnings management is negatively related to both board and audit committee independence. \\
\hline 55 & Meek et al. (2007) & $\begin{array}{l}\text { CEO stock option compensation } \\
\text { and earnings management. }\end{array}$ & 4398 firms for the period $1993-2001$ & Earnings management is more likely where stock options are a larger part of CEO compensation. \\
\hline 56 & Reed et al. (2007) & $\begin{array}{l}\text { Successor auditor appointment and } \\
\text { earnings management. }\end{array}$ & $\begin{array}{l}\text { Sample consists of all } 119 \text { publicly traded } \\
\text { clients (1985 - 1994). }\end{array}$ & $\begin{array}{l}\text { Replacing Laventol and Horwath with a new auditor resulted in a statistically significant decrease } \\
\text { in DAs. }\end{array}$ \\
\hline 57 & Johl et al. (2007) & $\begin{array}{l}\text { Audit quality, earnings } \\
\text { management, and financial crises. }\end{array}$ & $\begin{array}{l}3256 \text { firms covering financial periods } \\
\text { between } 1994 \text { and } 1999 \text {. }\end{array}$ & $\begin{array}{l}\text { Big } 5 \text { auditors in Malaysia appear to qualify more frequently than their non-Big } 5 \text { counterparts } \\
\text { when high levels of abnormal accruals are present. }\end{array}$ \\
\hline
\end{tabular}




\begin{tabular}{|c|c|c|c|c|}
\hline 58 & Chia et al. (2007) & $\begin{array}{l}\begin{array}{l}\text { Auditor quality and } \\
\text { management during }\end{array} \\
\text { crises. }\end{array}$ & $\begin{array}{l}\text { Sample covers } 383 \text { firm-observations for } \\
\text { the fiscal years of } 1995-1998 \text {. }\end{array}$ & $\begin{array}{l}\text { The results show that service-oriented companies engage in income decreasing earnings } \\
\text { management during the crisis period. }\end{array}$ \\
\hline 59 & Daniel et al. (2007) & $\begin{array}{l}\text { Earnings management and } \\
\text { avoidance of loss reporting. }\end{array}$ & $\begin{array}{l}\text { S\&P } 1500 \text { firms over the period } 1992- \\
2005\end{array}$ & Firms view expected dividend levels as important earnings thresholds \\
\hline 60 & $\begin{array}{l}\text { Caramanis and Lennox } \\
(2008)\end{array}$ & $\begin{array}{l}\text { Audit effort and earnings } \\
\text { management. }\end{array}$ & $\begin{array}{l}\text { Hours worked by auditors on } 9,738 \text { audits } \\
\text { in Greece between } 1994 \text { and } 2002\end{array}$ & $\begin{array}{l}\text { Low audit effort increases the extent to which managers are able to report aggressively high } \\
\text { earnings. }\end{array}$ \\
\hline 61 & Kerstein and Rai (2007) & $\begin{array}{l}\text { Earnings management and } \\
\text { avoidance of loss reporting }\end{array}$ & $\begin{array}{l}34,568 \text { firm-year observations from the } \\
\text { period } 1976 \text { to } 2005 \text {. }\end{array}$ & $\begin{array}{l}\text { A high proportion of firms with small cumulative profits or losses at the beginning of the fourth- } \\
\text { quarter report small annual profits rather than small annual losses }\end{array}$ \\
\hline 62 & $\begin{array}{l}\text { John and Jorgensen } \\
(2007)\end{array}$ & $\begin{array}{l}\text { Earnings management in fiscal } \\
\text { year earnings relative to these } \\
\text { alternative measures of firms' } \\
\text { annual earnings. }\end{array}$ & $\begin{array}{l}18,539 \text { firm-year observations for the } \\
\text { period } 1981-2001 \text {. }\end{array}$ & $\begin{array}{l}\text { Earnings management is not confined to the immediate vicinity of earnings threshold but is } \\
\text { discernible over boarder sections of earnings and earnings change histograms. }\end{array}$ \\
\hline 63 & $\begin{array}{l}\text { Bloomfield } \\
\text { Shackman (2008) }\end{array}$ & $\begin{array}{l}\text { The relationship of NAS fees to } \\
\text { the occurrence of financial } \\
\text { statement restatements. }\end{array}$ & $\begin{array}{l}\text { The test population was formed by } \\
\text { selecting } 250 \text { financial statement } \\
\text { restatements announced by public } \\
\text { companies for the period } 2001-2002 \text {. }\end{array}$ & $\begin{array}{l}\text { The study did find stronger evidence that the level of total fees paid to the audit firm is significant } \\
\text { in the predictability of a restatement. }\end{array}$ \\
\hline 64 & $\begin{array}{l}\text { Rock and Bonneti } \\
(2004) \text {. }\end{array}$ & $\begin{array}{l}\text { The relationship between } \\
\text { corruption, investment and growth. }\end{array}$ & $\begin{array}{l}\text { 4,689 firm-year observations for the } \\
\text { period 1992-1996. }\end{array}$ & $\begin{array}{l}\text { Corruption is more damaging to investment and growth in small developing countries than in large } \\
\text { ones. }\end{array}$ \\
\hline 65 & $\begin{array}{l}\text { Ades and Di Tella } \\
\text { (1997). }\end{array}$ & $\begin{array}{l}\text { To examine the relationship } \\
\text { between interventionist industrial } \\
\text { policies and corruption. }\end{array}$ & $\begin{array}{l}9,616 \text { firm-year observations for the } \\
\text { period 1989-1992. }\end{array}$ & $\begin{array}{l}\text { It is more expensive to achieve the desired objective using active industrial policies in economies } \\
\text { where corruption is widespread than in corruption - free environments. }\end{array}$ \\
\hline 66 & La Porta et al. (1998). & $\begin{array}{l}\text { Investor protection and ownership } \\
\text { concentration. }\end{array}$ & 49 countries around the world. & $\begin{array}{l}\text { The study results show that common-law countries generally have the strongest, and French civil- } \\
\text { law countries the weakest, legal protections of investors, with German- and Scandinavian-civil-law } \\
\text { countries located in the middle. They also finds that concentration of ownership of shares in the } \\
\text { largest public companies is negatively related to investor protections, consistent with the } \\
\text { hypothesis that small, diversified shareholders are unlikely to be important in countries that fail to } \\
\text { protect their rights. }\end{array}$ \\
\hline 67 & Hoopes et al. (2006) & $\begin{array}{l}\text { Relationship between accounting } \\
\text { and corruption }\end{array}$ & $\begin{array}{l}\text { Sample consists of } 67 \text { countries around } \\
\text { the world. }\end{array}$ & Better accounting and auditing quality can reduce corruption. \\
\hline
\end{tabular}

\section{Appendix - D}




\section{Robustness test}

Table 5-17

(Using cross-sectional Jones (1991) model)

Regression analysis of discretionary accruals with macro governance

(Dependent variable is signed discretionary accruals: DACCR)

DACCR $_{\text {it }}=\alpha_{0}+\alpha_{\mathbf{1}}$ MACRO $+\alpha_{2}$ SIZE $_{\text {it }}+\alpha_{3} \mathrm{LEV}_{\mathrm{it}}+\alpha_{4} \mathrm{GWTH}_{\mathrm{it}}+\alpha_{5} \mathrm{CFO}_{\mathrm{it}}+\alpha_{6} \mathrm{CAP}_{\mathrm{it}}+\alpha_{7} \mathrm{LOSS}_{\mathrm{it}}+$ fixed effects..... (i)

\begin{tabular}{|c|c|c|c|c|c|c|c|c|c|c|c|}
\hline Independent & JUD & SEC & MIN & ACC & RLAW & PRESS & INS & POL & COR & CUL & IFRS \\
\hline & $\begin{array}{l}\text { Estimate } \\
\text { (p-value) }\end{array}$ & $\begin{array}{l}\text { Estimate } \\
\text { (p-value) }\end{array}$ & $\begin{array}{l}\text { Estimate } \\
\text { (p-value) }\end{array}$ & $\begin{array}{l}\text { Estimate } \\
\text { (p-value) }\end{array}$ & $\begin{array}{l}\text { Estimate } \\
\text { (p-value) }\end{array}$ & $\begin{array}{l}\text { Estimate } \\
\text { (p-value) }\end{array}$ & $\begin{array}{l}\text { Estimate } \\
\text { (p-value) }\end{array}$ & $\begin{array}{l}\text { Estimate } \\
\text { (p-value) }\end{array}$ & $\begin{array}{l}\text { Estimate } \\
\text { (p-value) }\end{array}$ & $\begin{array}{l}\text { Estimate } \\
\text { (p-value) }\end{array}$ & $\begin{array}{l}\text { Estimate } \\
\text { (p-value) }\end{array}$ \\
\hline Constant & $\begin{array}{l}.009 \\
(.023)\end{array}$ & $\begin{array}{l}-.011 \\
(.027)\end{array}$ & $\begin{array}{c}.041 \\
(<.01)\end{array}$ & $\begin{array}{c}.042 \\
(<.01)\end{array}$ & $\begin{array}{l}-.017 \\
(<.01)\end{array}$ & $\begin{array}{l}-.027 \\
(<.01)\end{array}$ & $\begin{array}{l}-.021 \\
(<.01)\end{array}$ & $\begin{array}{l}-.037 \\
(<.01)\end{array}$ & $\begin{array}{l}-.024 \\
(<.01)\end{array}$ & $\begin{array}{c}.033 \\
(<.01)\end{array}$ & $\begin{array}{l}-.034 \\
(<.01)\end{array}$ \\
\hline MACRO & $\begin{array}{l}-.009 \\
(<.01)\end{array}$ & $\begin{array}{l}-.005 \\
(<.01)\end{array}$ & $\begin{array}{l}-.015 \\
(<.01)\end{array}$ & $\begin{array}{c}-.014 \\
(<.01)\end{array}$ & $\begin{array}{c}-.029 \\
(<.01)\end{array}$ & $\begin{array}{l}-.017 \\
(<.01)\end{array}$ & $\begin{array}{l}-.029 \\
(<.01)\end{array}$ & $\begin{array}{l}-.022 \\
(<.01)\end{array}$ & $\begin{array}{c}-.022 \\
(<.01)\end{array}$ & $\begin{array}{r}-.015 \\
(<.01)\end{array}$ & $\begin{array}{c}.013 \\
(<.01)\end{array}$ \\
\hline Size & $\begin{array}{c}.007 \\
(<.01)\end{array}$ & $\begin{array}{c}.007 \\
(<.01)\end{array}$ & $\begin{array}{l}.006 \\
(<.01)\end{array}$ & $\begin{array}{c}.006 \\
(<.01)\end{array}$ & $\begin{array}{c}.010 \\
(<.01)\end{array}$ & $\begin{array}{c}.008 \\
(<.01)\end{array}$ & $\begin{array}{l}.010 \\
(<.01)\end{array}$ & $\begin{array}{c}.009 \\
(<.01)\end{array}$ & $\begin{array}{c}.010 \\
(<.01)\end{array}$ & $\begin{array}{c}.008 \\
(<.01)\end{array}$ & $\begin{array}{l}.006 \\
(<.01)\end{array}$ \\
\hline LEV & $\begin{array}{c}.018 \\
(<.01)\end{array}$ & $\begin{array}{c}.018 \\
(<.01)\end{array}$ & $\begin{array}{c}.018 \\
(<.01)\end{array}$ & $\begin{array}{c}.018 \\
(<.01)\end{array}$ & $\begin{array}{c}.018 \\
(<.01)\end{array}$ & $\begin{array}{c}.018 \\
(<.01)\end{array}$ & $\begin{array}{c}.017 \\
(<.01)\end{array}$ & $\begin{array}{c}.017 \\
(<.01)\end{array}$ & $\begin{array}{c}.018 \\
(<.01)\end{array}$ & $\begin{array}{c}.018 \\
(<.01)\end{array}$ & $\begin{array}{l}.018 \\
(<.01)\end{array}$ \\
\hline GWTH & $\begin{array}{c}.052 \\
(<.01)\end{array}$ & $\begin{array}{c}.053 \\
(<.01)\end{array}$ & $\begin{array}{c}.053 \\
(<.01)\end{array}$ & $\begin{array}{c}.053 \\
(<.01)\end{array}$ & $\begin{array}{c}.052 \\
(<.01)\end{array}$ & $\begin{array}{c}.054 \\
(<.01)\end{array}$ & $\begin{array}{c}.052 \\
(<.01)\end{array}$ & $\begin{array}{c}.053 \\
(<.01)\end{array}$ & $\begin{array}{c}.053 \\
(<.01)\end{array}$ & $\begin{array}{c}.052 \\
(<.01)\end{array}$ & $\begin{array}{l}.054 \\
(<.01)\end{array}$ \\
\hline $\mathrm{CFO}$ & $\begin{array}{l}-.370 \\
(<.01)\end{array}$ & $\begin{array}{l}-.370 \\
(<.01)\end{array}$ & $\begin{array}{l}-.369 \\
(<.01)\end{array}$ & $\begin{array}{l}-.369 \\
(<.01)\end{array}$ & $\begin{array}{l}-.381 \\
(<.01)\end{array}$ & $\begin{array}{l}-.383 \\
(<.01)\end{array}$ & $\begin{array}{l}-.382 \\
(<.01)\end{array}$ & $\begin{array}{l}-.385 \\
(<.01)\end{array}$ & $\begin{array}{l}-.382 \\
(<.01)\end{array}$ & $\begin{array}{l}-.370 \\
(<.01)\end{array}$ & $\begin{array}{l}-.383 \\
(<.01)\end{array}$ \\
\hline CAP & $\begin{array}{l}.183 \\
(<.01)\end{array}$ & $\begin{array}{l}.186 \\
(<.01)\end{array}$ & $\begin{array}{l}.183 \\
(<.01)\end{array}$ & $\begin{array}{l}.182 \\
(<.01)\end{array}$ & $\begin{array}{l}.171 \\
(<.01)\end{array}$ & $\begin{array}{l}.177 \\
(<.01)\end{array}$ & $\begin{array}{l}.172 \\
(<.01)\end{array}$ & $\begin{array}{l}.180 \\
(<.01)\end{array}$ & $\begin{array}{l}.173 \\
(<.01)\end{array}$ & $\begin{array}{l}.182 \\
(<.01)\end{array}$ & $\begin{array}{l}.187 \\
(<.01)\end{array}$ \\
\hline LOSS & $\begin{array}{l}-.146 \\
(<.01)\end{array}$ & $\begin{array}{l}-.145 \\
(<.01)\end{array}$ & $\begin{array}{l}-.144 \\
(<.01)\end{array}$ & $\begin{array}{l}-.144 \\
(<.01)\end{array}$ & $\begin{array}{l}-.138 \\
(<.01)\end{array}$ & $\begin{array}{l}-.140 \\
(<.01)\end{array}$ & $\begin{array}{l}-.138 \\
(<.01)\end{array}$ & $\begin{array}{l}-.143 \\
(<.01)\end{array}$ & $\begin{array}{l}-.138 \\
(<.01)\end{array}$ & $\begin{array}{l}-.145 \\
(<.01)\end{array}$ & $\begin{array}{l}-.145 \\
(<.01)\end{array}$ \\
\hline $\begin{array}{c}\text { fixed effects } \\
\text { Adj. } \mathbf{R}^{2}\end{array}$ & $\begin{array}{c}\text { included } \\
.280\end{array}$ & $\begin{array}{c}\text { included } \\
.281\end{array}$ & $\begin{array}{c}\text { included } \\
.283\end{array}$ & $\begin{array}{c}\text { included } \\
.283\end{array}$ & $\begin{array}{c}\text { included } \\
.298\end{array}$ & $\begin{array}{c}\text { included } \\
.290\end{array}$ & $\begin{array}{c}\text { included } \\
.297\end{array}$ & $\begin{array}{c}\text { included } \\
.291\end{array}$ & $\begin{array}{c}\text { included } \\
.296\end{array}$ & $\begin{array}{l}\text { included } \\
.284\end{array}$ & $\begin{array}{c}\text { included } \\
.284\end{array}$ \\
\hline $\mathbf{N}$ & 156,906 & 156,906 & 156,906 & 156,906 & 156,906 & 156,906 & 156,906 & 156,906 & 156,906 & 156,906 & $\mathbf{N}$ \\
\hline
\end{tabular}

Note: Coefficient p-values are two-tail and based on asymptotic Z-statistic robust to hetroscedasticity and country clustering effects using the method in Rogers (1993). Coefficient on Year dummies and country dummies are not reported for concision.

JUD $=$ judicial independence $($ WEF 2008). SEC $=$ enforcement of securities laws (WEF 2008). MIN $=$ protection of minority shareholders interest $($ WEF 2008). ENF = enforcement of accounting \& auditing standards (WEF 2008). RLAW = rule of laws (WB 1999- 2007). PRESS = press freedom (WB 1999 2007). INS = 207). behavor (WEF 200 S discretionary accruals. SIZE is the natural logarithm of total assets in $\$$ thousands for firm 1 in year t. LEV is total liabilities / total equities for firm 1 in year $t$. GWTH is return on equity, defined as the net income in year $t$ scaled by total equity in year $t$. CFO is the operating cash flows for firm 1 in year $t$ scaled by lagged total assets. CAP is the non-current (fixed) assets in year $\mathrm{t} /$ Total assets in year t. LOSS takes the value of 1 if firm i reports income before extraordinary items in the previous year negative and 0 otherwise. 
Table 5-18

(Using cross-sectional Jones (1991) model)

Regression analysis of discretionary accruals with micro governance

(Dependent variable is signed discretionary accruals: DACCR)

DACCR $_{\text {it }}=\alpha_{0}+\alpha_{1}$ MICRO $+\alpha_{2}$ SIZE $_{i t}+\alpha_{3} \mathrm{GWTH}_{\mathrm{it}} \alpha_{4} \mathrm{CFO}_{\mathrm{it}}+\alpha_{5} \mathrm{CAP}_{\mathrm{it}}+\alpha_{6} \mathrm{LOSS}_{\mathrm{it}}+$ fixed effects

\begin{tabular}{|c|c|c|c|c|c|c|c|}
\hline \multirow{2}{*}{$\begin{array}{l}\text { Independent } \\
\text { variables }\end{array}$} & BIG4 & BOD & BIND & OWN & IPO & LEV & BONUS \\
\hline & $\begin{array}{l}\text { Estimate } \\
\text { (p-value) }\end{array}$ & $\begin{array}{l}\text { Estimate } \\
\text { (p-value) }\end{array}$ & $\begin{array}{l}\text { Estimate } \\
\text { (p-value) }\end{array}$ & $\begin{array}{l}\text { Estimate } \\
\text { (p-value) }\end{array}$ & $\begin{array}{l}\text { Estimate } \\
\text { (p-value) }\end{array}$ & $\begin{array}{l}\text { Estimate } \\
\text { (p-value) }\end{array}$ & $\begin{array}{l}\text { Estimate } \\
\text { (p-value) }\end{array}$ \\
\hline Constant & $\begin{array}{l}-.043 \\
(<.01)\end{array}$ & $\begin{array}{l}-.033 \\
(<.01)\end{array}$ & $\begin{array}{l}.093 \\
(<.01)\end{array}$ & $\begin{array}{l}-.083 \\
(<.01)\end{array}$ & $\begin{array}{l}-.030 \\
(<.01)\end{array}$ & $\begin{array}{l}.132 \\
(<.01)\end{array}$ & $\begin{array}{l}.114 \\
(<.01)\end{array}$ \\
\hline MICRO & $\begin{array}{c}-.013 \\
(<.01)\end{array}$ & $\begin{array}{c}-.001 \\
(<.01)\end{array}$ & $\begin{array}{c}-.025 \\
(<.01)\end{array}$ & $\begin{array}{c}.133 \\
(<.01)\end{array}$ & $\begin{array}{c}.003 \\
(<.01)\end{array}$ & $\begin{array}{c}.015 \\
(<.01)\end{array}$ & $\begin{array}{c}-.030 \\
(<.01)\end{array}$ \\
\hline Size & $\begin{array}{l}.009 \\
(<.01)\end{array}$ & $\begin{array}{l}.008 \\
(<.01)\end{array}$ & $\begin{array}{c}.007 \\
(<.01)\end{array}$ & $\begin{array}{c}.009 \\
(<.01)\end{array}$ & $\begin{array}{c}.010 \\
(<.01)\end{array}$ & $\begin{array}{l}-.001 \\
(.193)\end{array}$ & $\begin{array}{l}.007 \\
(<.01)\end{array}$ \\
\hline LEV & $\begin{array}{c}.018 \\
(<.01)\end{array}$ & $\begin{array}{c}.018 \\
(<.01)\end{array}$ & $\begin{array}{c}.018 \\
(<.01)\end{array}$ & $\begin{array}{c}.017 \\
(<.01)\end{array}$ & $\begin{array}{l}.017 \\
(<.01)\end{array}$ & $\begin{array}{l}-.488 \\
(<.01)\end{array}$ & $\begin{array}{l}.018 \\
(<.01)\end{array}$ \\
\hline GWTH & $\begin{array}{l}.054 \\
(<.01)\end{array}$ & $\begin{array}{c}.054 \\
(<.01)\end{array}$ & $\begin{array}{c}.052 \\
(<.01)\end{array}$ & $\begin{array}{c}.051 \\
(<.01)\end{array}$ & $\begin{array}{c}.051 \\
(<.01)\end{array}$ & $\begin{array}{c}.044 \\
(<.01)\end{array}$ & $\begin{array}{l}.052 \\
(<.01)\end{array}$ \\
\hline CFO & $\begin{array}{l}-.381 \\
(<.01)\end{array}$ & $\begin{array}{l}-.390 \\
(<.01)\end{array}$ & $\begin{array}{l}-.369 \\
(<.01)\end{array}$ & $\begin{array}{l}-.362 \\
(<.01)\end{array}$ & $\begin{array}{l}-.362 \\
(<.01)\end{array}$ & $\begin{array}{l}-.351 \\
(<.01)\end{array}$ & $\begin{array}{l}-.367 \\
(<.01)\end{array}$ \\
\hline CAP & $\begin{array}{l}.184 \\
(<.01)\end{array}$ & $\begin{array}{l}.183 \\
(<.01)\end{array}$ & $\begin{array}{l}.181 \\
(<.01)\end{array}$ & $\begin{array}{l}.173 \\
(<.01)\end{array}$ & $\begin{array}{l}.172 \\
(<.01)\end{array}$ & $\begin{array}{l}.070 \\
(<.01)\end{array}$ & $\begin{array}{l}.178 \\
(<.01)\end{array}$ \\
\hline LOSS & $\begin{array}{l}-.145 \\
(<.01)\end{array}$ & $\begin{array}{l}-.145 \\
(<.01)\end{array}$ & $\begin{array}{l}-.142 \\
(<.01)\end{array}$ & $\begin{array}{l}-.138 \\
(<.01)\end{array}$ & $\begin{array}{l}-.139 \\
(<.01)\end{array}$ & $\begin{array}{l}-.105 \\
(<.01)\end{array}$ & $\begin{array}{l}-.139 \\
(<.01)\end{array}$ \\
\hline fixed effects & included & included & included & included & included & included & included \\
\hline Adj. $\mathbf{R}^{2}$ & .285 & .286 & .285 & .295 & .291 & .452 & .288 \\
\hline $\mathbf{N}$ & 156,906 & 156,906 & 156,906 & 156,906 & 156,906 & 156,906 & 156,906 \\
\hline
\end{tabular}

Note: Coefficient p-values are two-tail and based on asymptotic Z-statistic robust to hetroscedasticity and country clustering effects using the method in Rogers (1993). Coefficient on Year dummies and country dummies are not reported for concision.

BIG4 $=$ indicator variable with the value of 1 if the firm audited by one of the BIG4 and otherwise $0 . \quad$ BOD $=$ no of directors on the board of a firm BIND = board effectiveness (WEF 2008). OWN = ownership concentration (La Porta et al. 2006). IPO = initial public offerings (WEF 2008). LEV $=$ debt divided by equity of a firm. BONUS = performance based compensation (WEF 2008). DACCR = signed discretionary accruals. SIZE is the natural logarithm of total assets in \$ thousands for firm i in year t. LEV is total liabilities / total equities for firm i in year t. GWTH is return on equity, defined as the net income in year $t$ scaled by total equity in year $t$. CFO is the operating cash flows for firm $i$ in year $t$ scaled by lagged total items in the previous year negative and 0 otherwise. 


\section{Table 5-19}

\section{(Deleting smaller countries)}

\section{Regression analysis of discretionary accruals with macro governance}

(Dependent variable is signed discretionary accruals: DACCR)

\begin{tabular}{|c|c|c|c|c|c|c|c|c|c|c|c|}
\hline & JUD & SEC & MIN & ACC & RLAW & PRESS & INS & POL & COR & CUL & IFRS \\
\hline $\begin{array}{l}\text { Independent } \\
\text { variables }\end{array}$ & $\begin{array}{c}\text { Estimate } \\
\text { (p-value) }\end{array}$ & $\begin{array}{l}\text { Estimate } \\
\text { (p-value) }\end{array}$ & $\begin{array}{l}\text { Estimate } \\
\text { (p-value) }\end{array}$ & $\begin{array}{l}\text { Estimate } \\
\text { (p-value) }\end{array}$ & $\begin{array}{l}\text { Estimate } \\
\text { (p-value) }\end{array}$ & $\begin{array}{l}\text { Estimate } \\
\text { (p-value) }\end{array}$ & $\begin{array}{l}\text { Estimate } \\
\text { (p-value) }\end{array}$ & $\begin{array}{l}\text { Estimate } \\
\text { (p-value) }\end{array}$ & $\begin{array}{l}\text { Estimate } \\
\text { (p-value) }\end{array}$ & $\begin{array}{l}\text { Estimate } \\
\text { (p-value) }\end{array}$ & $\begin{array}{l}\text { Estimate } \\
\text { (p-value) }\end{array}$ \\
\hline Constant & $\begin{array}{l}-.324 \\
(<.01)\end{array}$ & $\begin{array}{l}-.371 \\
(<.01)\end{array}$ & $\begin{array}{l}-.357 \\
(<.01)\end{array}$ & $\begin{array}{l}-.349 \\
(<.01)\end{array}$ & $\begin{array}{l}-.358 \\
(<.01)\end{array}$ & $\begin{array}{l}-.363 \\
(<.01)\end{array}$ & $\begin{array}{l}-.363 \\
(<.01)\end{array}$ & $\begin{array}{l}-.359 \\
(<.01)\end{array}$ & $\begin{array}{l}-.362 \\
(<.01)\end{array}$ & $\begin{array}{l}-.304 \\
(<.01)\end{array}$ & $\begin{array}{l}-.364 \\
(<.01)\end{array}$ \\
\hline MACRO & $\begin{array}{l}-.008 \\
(<.01)\end{array}$ & $\begin{array}{c}.001 \\
. .171)\end{array}$ & $\begin{array}{l}-.002 \\
(.075)\end{array}$ & $\begin{array}{l}-.003 \\
(<.01)\end{array}$ & $\begin{array}{l}-.023 \\
(<.01)\end{array}$ & $\begin{array}{l}-.012 \\
(<.01)\end{array}$ & $\begin{array}{l}-.023 \\
(<.01)\end{array}$ & $\begin{array}{l}-.021 \\
(<.01)\end{array}$ & $\begin{array}{l}-.017 \\
(<.01)\end{array}$ & $\begin{array}{l}-.013 \\
(<.01)\end{array}$ & $\begin{array}{c}.009 \\
(<.01)\end{array}$ \\
\hline Size & $\begin{array}{c}.018 \\
(<.01)\end{array}$ & $\begin{array}{c}.018 \\
(<.01)\end{array}$ & $\begin{array}{c}.018 \\
(<.01)\end{array}$ & $\begin{array}{c}.018 \\
(<.01)\end{array}$ & $\begin{array}{c}.020 \\
(<.01)\end{array}$ & $\begin{array}{c}.019 \\
(<.01)\end{array}$ & $\begin{array}{c}.020 \\
(<.01)\end{array}$ & $\begin{array}{c}.020 \\
(<.01)\end{array}$ & $\begin{array}{l}.020 \\
(<.01)\end{array}$ & $\begin{array}{c}.018 \\
(<.01)\end{array}$ & $\begin{array}{l}.017 \\
(<.01)\end{array}$ \\
\hline LEV & $\begin{array}{l}.102 \\
(<.01)\end{array}$ & $\begin{array}{l}.100 \\
(<.01)\end{array}$ & $\begin{array}{l}.100 \\
(<.01)\end{array}$ & $\begin{array}{l}.101 \\
(<.01)\end{array}$ & $\begin{array}{l}.101 \\
(<.01)\end{array}$ & $\begin{array}{l}.100 \\
(<.01)\end{array}$ & $\begin{array}{l}.100 \\
(<.01)\end{array}$ & $\begin{array}{c}.096 \\
(<.01)\end{array}$ & $\begin{array}{c}.099 \\
(<.01)\end{array}$ & $\begin{array}{l}.101 \\
(<.01)\end{array}$ & $\begin{array}{c}.097 \\
(<.01)\end{array}$ \\
\hline GWTH & $\begin{array}{l}-.033 \\
(<.01)\end{array}$ & $\begin{array}{l}-.033 \\
(<.01)\end{array}$ & $\begin{array}{l}-.033 \\
(<.01)\end{array}$ & $\begin{array}{l}-.033 \\
(<.01)\end{array}$ & $\begin{array}{l}-.030 \\
(<.01)\end{array}$ & $\begin{array}{l}-.031 \\
(<.01)\end{array}$ & $\begin{array}{l}-.030 \\
(<.01)\end{array}$ & $\begin{array}{l}-.031 \\
(<.01)\end{array}$ & $\begin{array}{l}-.030 \\
(<.01)\end{array}$ & $\begin{array}{l}-.033 \\
(<.01)\end{array}$ & $\begin{array}{l}-.031 \\
(<.01)\end{array}$ \\
\hline $\mathrm{CFO}$ & $\begin{array}{c}.374 \\
(<.01)\end{array}$ & $\begin{array}{l}-.375 \\
(<.01)\end{array}$ & $\begin{array}{l}-.375 \\
(<.01)\end{array}$ & $\begin{array}{l}-.375 \\
(<.01)\end{array}$ & $\begin{array}{l}-.386 \\
(<.01)\end{array}$ & $\begin{array}{l}-.386 \\
(<.01)\end{array}$ & $\begin{array}{l}-.387 \\
(<.01)\end{array}$ & $\begin{array}{l}-.388 \\
(<.01)\end{array}$ & $\begin{array}{l}-.386 \\
(<.01)\end{array}$ & $\begin{array}{l}-.375 \\
(<.01)\end{array}$ & $\begin{array}{l}.-.386 \\
(<.01)\end{array}$ \\
\hline CAP & $\begin{array}{c}.445 \\
(<.01)\end{array}$ & $\begin{array}{c}.448 \\
(<.01)\end{array}$ & $\begin{array}{c}.448 \\
(<.01)\end{array}$ & $\begin{array}{c}.447 \\
(<.01)\end{array}$ & $\begin{array}{c}.438 \\
(<.01)\end{array}$ & $\begin{array}{c}.443 \\
(<.01)\end{array}$ & $\begin{array}{c}.440 \\
(<.01)\end{array}$ & $\begin{array}{c}.442 \\
(<.01)\end{array}$ & $\begin{array}{l}.440 \\
(<.01)\end{array}$ & $\begin{array}{c}.444 \\
(<.01)\end{array}$ & $\begin{array}{c}.449 \\
(<.01)\end{array}$ \\
\hline LOSS & $\begin{array}{l}-.146 \\
(<.01)\end{array}$ & $\begin{array}{l}-.147 \\
(<.01)\end{array}$ & $\begin{array}{l}-.147 \\
(<.01)\end{array}$ & $\begin{array}{l}-.146 \\
(<.01)\end{array}$ & $\begin{array}{l}-.143 \\
(<.01)\end{array}$ & $\begin{array}{l}-.145 \\
(<.01)\end{array}$ & $\begin{array}{l}-.144 \\
(<.01)\end{array}$ & $\begin{array}{c}-.142 \\
(<.01)\end{array}$ & $\begin{array}{l}-.144 \\
(<.01)\end{array}$ & $\begin{array}{l}-.146 \\
(<.01)\end{array}$ & $\begin{array}{l}-.147 \\
(<.01)\end{array}$ \\
\hline fixed effects & included & included & included & included & included & included & included & included & included & included & included \\
\hline Adj. $\mathbf{R}^{2}$ & .429 & .428 & .428 & .428 & .432 & .429 & .431 & .431 & .431 & .429 & .427 \\
\hline $\mathbf{N}$ & 115,809 & 115,809 & 115,809 & 115,809 & 115,809 & 115,809 & 115,809 & 115,809 & 115,809 & 115,809 & 115,809 \\
\hline
\end{tabular}

Note: Coefficient p-values are two-tail and based on asymptotic Z-statistic robust to hetroscedasticity and country clustering effects using the method in Rogers (1993). Coefficient on Year dummies and country dummies are not reported for concision.

JUD $=$ judicial independence $($ WEF 2008). SEC $=$ enforcement of securities laws (WEF 2008). MIN = protection of minority shareholders interest $($ WEF 2008). $\mathbf{E N F}=$ enforcement of accounting \& auditing standards (WEF 2008). RLAW = rule of laws (WB 1999-2007). PRESS = press freedom (WB 19992007). INS = regulatory quality (WB 1999-2007). $\mathbf{P O L}=$ political stability $($ WB 1999-2007). COR = control of corruption $($ WB 1999-2007). CUL = ethical behaviour $($ WEF 2008). IFRS = A dummy variable takes the value of 1 for a given year after mandatory IFRS adoption and 0 otherwise. $\mathbf{D A C C R}=$ signed discretionary accruals. SIZE is the natural logarithm of total assets in $\$$ thousands for firm i in year t. LEV is total liabilities / total equities for firm $i$ in year t. GWTH is return on equity, defined as the net income in year $t$ scaled by total equity in year $t$. CFO is the operating cash flows for firm i in year $t$ scaled by lagged total assets. CAP is the non-current (fixed) assets in year $\mathrm{t} /$ Total assets in year t. LOSS takes the value of 1 if firm i reports income before lagged total assets. CAP is the non-current (fixed) assets in year
extraordinary items in the previous year negative and 0 otherwise. 
Table 5-20

(Deleting smaller countries)

Regression analysis of discretionary accruals with micro governance (Dependent variable is signed discretionary accruals: DACCR)

DACCR $_{\text {it }}=\alpha_{0}+\alpha_{1}$ MICRO $+\alpha_{2}$ SIZE $_{i t}+\beta_{3} G_{W T H} \alpha_{4}$ CFO $_{\text {it }}+\alpha_{5}$ CAP $_{i t}+\alpha_{6} L_{\text {LOSS }}+$ fixed effects.

\begin{tabular}{|c|c|c|c|c|c|c|c|}
\hline \multirow{2}{*}{$\begin{array}{l}\text { Independent } \\
\text { variables }\end{array}$} & BIG4 & BOD & BIND & OWN & IPO & LEV & BONUS \\
\hline & $\begin{array}{l}\text { Estimate } \\
\text { (p-value) }\end{array}$ & $\begin{array}{l}\text { Estimate } \\
\text { (p-value) }\end{array}$ & $\begin{array}{l}\text { Estimate } \\
\text { (p-value) }\end{array}$ & $\begin{array}{l}\text { Estimate } \\
\text { (p-value) }\end{array}$ & $\begin{array}{l}\text { Estimate } \\
\text { (p-value) }\end{array}$ & $\begin{array}{l}\text { Estimate } \\
\text { (p-value) }\end{array}$ & $\begin{array}{l}\text { Estimate } \\
\text { (p-value) }\end{array}$ \\
\hline Constant & $\begin{array}{l}-.375 \\
(<.01)\end{array}$ & $\begin{array}{l}-.367 \\
(<.01)\end{array}$ & $\begin{array}{l}.305 \\
(<.01)\end{array}$ & $\begin{array}{l}-.413 \\
(<.01)\end{array}$ & $\begin{array}{l}-.365 \\
(<.01)\end{array}$ & $\begin{array}{l}-.177 \\
(<.01)\end{array}$ & $\begin{array}{l}-.304 \\
(<.01)\end{array}$ \\
\hline MICRO & $\begin{array}{c}-.012 \\
(<.01)\end{array}$ & $\begin{array}{l}-.000 \\
(<.01)\end{array}$ & $\begin{array}{c}-.012 \\
(<.01)\end{array}$ & $\begin{array}{c}.119 \\
(<.01)\end{array}$ & $\begin{array}{l}-.002 \\
(<.01)\end{array}$ & $\begin{array}{c}.065 \\
(<.01)\end{array}$ & $\begin{array}{c}-.013 \\
(<.01)\end{array}$ \\
\hline Size & $\begin{array}{c}.020 \\
(<.01)\end{array}$ & $\begin{array}{l}.018 \\
(<.01)\end{array}$ & $\begin{array}{c}.018 \\
(<.01)\end{array}$ & $\begin{array}{c}.019 \\
(<.01)\end{array}$ & $\begin{array}{l}.021 \\
(<.01)\end{array}$ & $\begin{array}{l}.009 \\
(<.01)\end{array}$ & $\begin{array}{c}.018 \\
(<.01)\end{array}$ \\
\hline LEV & $\begin{array}{c}.098 \\
(<.01)\end{array}$ & $\begin{array}{l}.098 \\
(<.01)\end{array}$ & $\begin{array}{l}.102 \\
(<.01)\end{array}$ & $\begin{array}{c}.097 \\
(<.01)\end{array}$ & $\begin{array}{l}.100 \\
(<.01)\end{array}$ & $\begin{array}{l}-.552 \\
(<.01)\end{array}$ & $\begin{array}{l}.101 \\
(<.01)\end{array}$ \\
\hline GWTH & $\begin{array}{l}-.031 \\
(<.01)\end{array}$ & $\begin{array}{l}-.030 \\
(<.01)\end{array}$ & $\begin{array}{l}-.033 \\
(<.01)\end{array}$ & $\begin{array}{l}-.034 \\
(<.01)\end{array}$ & $\begin{array}{l}-.034 \\
(<.01)\end{array}$ & $\begin{array}{l}-.001 \\
(.077)\end{array}$ & $\begin{array}{l}-.033 \\
(<.01)\end{array}$ \\
\hline $\mathrm{CFO}$ & $\begin{array}{l}-.386 \\
(<.01)\end{array}$ & $\begin{array}{l}-.395 \\
(<.01)\end{array}$ & $\begin{array}{c}.375 \\
(<.01)\end{array}$ & $\begin{array}{l}-.370 \\
(<.01)\end{array}$ & $\begin{array}{l}-.369 \\
(<.01)\end{array}$ & $\begin{array}{l}-.341 \\
(<.01)\end{array}$ & $\begin{array}{l}-.374 \\
(<.01)\end{array}$ \\
\hline CAP & $\begin{array}{c}.448 \\
(<.01)\end{array}$ & $\begin{array}{c}.448 \\
(<.01)\end{array}$ & $\begin{array}{c}.446 \\
(<.01)\end{array}$ & $\begin{array}{l}.439 \\
(<.01)\end{array}$ & $\begin{array}{l}.438 \\
(<.01)\end{array}$ & $\begin{array}{l}.322 \\
(<.01)\end{array}$ & $\begin{array}{l}.445 \\
(<.01)\end{array}$ \\
\hline LOSS & $\begin{array}{l}-.147 \\
(<.01)\end{array}$ & $\begin{array}{l}-.147 \\
(<.01)\end{array}$ & $\begin{array}{l}-.146 \\
(<.01)\end{array}$ & $\begin{array}{l}-.144 \\
(<.01)\end{array}$ & $\begin{array}{l}-.144 \\
(<.01)\end{array}$ & $\begin{array}{l}-.101 \\
(<.01)\end{array}$ & $\begin{array}{l}-.145 \\
(<.01)\end{array}$ \\
\hline fixed effects & included & included & included & included & included & included & included \\
\hline Adj. $R^{2}$ & .427 & .427 & .428 & .432 & .430 & .558 & .428 \\
\hline $\mathbf{N}$ & 115,809 & 115,809 & 115,809 & 115,809 & 115,809 & 115,809 & 115,809 \\
\hline
\end{tabular}

Note: Coefficient p-values are two-tail and based on asymptotic Z-statistic robust to hetroscedasticity and country clustering effects using the method in Rogers (1993). Coefficient on Year dummies and country dummies are not reported for concision.

BIG4 = indicator variable with the value of 1 if the firm audited by one of the BIG4 and otherwise $0 . \quad$ BOD $=$ no of directors on the board of a firm BIND = board effectiveness (WEF 2008). OWN = ownership concentration (La Porta et al. 2006). IPO = initial public offerings (WEF 2008). LEV = debt dived by equity of a firm. BONUS = peffor is the cin is the nat lo equity, defined as the net income in yeart scaled by total equity in year $t$. CFO assets. CAP is the non-current (fixed) assets in year t / Total assets in year t. LOSS takes the value of 1 if firm i reports income before extraordinary items in the previous year negative and 0 otherwise. 
